
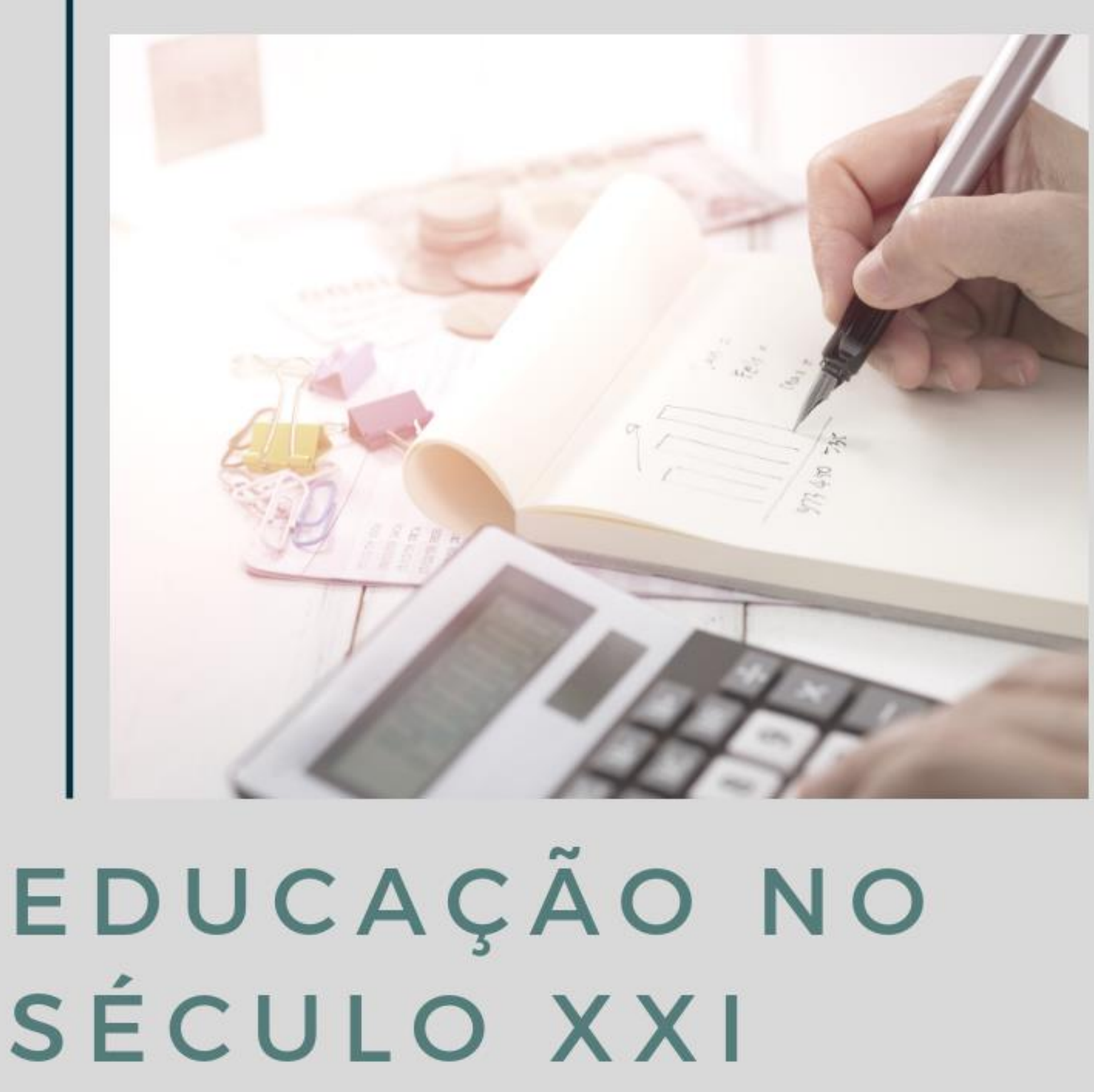

Matemática

\title{
VOLUME
}


Editora Poisson

\section{Educação no Século XXI Volume 10}

1a Edição

Belo Horizonte

Poisson

2019 


\section{Editor Chefe: Dr. Darly Fernando Andrade}

\section{Conselho Editorial}

Dr. Antônio Artur de Souza - Universidade Federal de Minas Gerais

Ms. Davilson Eduardo Andrade

Msc. Fabiane dos Santos Toledo

Dr. José Eduardo Ferreira Lopes - Universidade Federal de Uberlândia Dr. Otaviano Francisco Neves - Pontifícia Universidade Católica de Minas Gerais

Dr. Luiz Cláudio de Lima - Universidade FUMEC

Dr. Nelson Ferreira Filho - Faculdades Kennedy

Ms. Valdiney Alves de Oliveira - Universidade Federal de Uberlândia

Dados Internacionais de Catalogação na Publicação (CIP)
E24 Educação no Século XXI - Matemática - Volume
10/ Organização Editora Poisson - Belo
Horizonte - MG: Poisson, 2019
153p
Formato: PDF
ISBN: 978-85-7042-087-9
DOI: 10.5935/978-85-7042-087-9
Modo de acesso: World Wide Web
Inclui bibliografia
1. Educação 2. Tecnologia. I. Título
CDD-370

O conteúdo dos artigos e seus dados em sua forma, correção e confiabilidade são de responsabilidade exclusiva dos seus respectivos autores

www.poisson.com.br

contato@poisson.com.br 


\section{SUMÁRIO}

Capítulo 1: Modelagem matemática na educação básica: Uma proposta de análise do currículo construído na interação do processo de ensino e aprendizagem 6

Derli Kaczmarek, Dionísio Burak

Capítulo 2: Alfabetização matemática na perspectiva do letramento: Alguns apontamentos a partir do pacto nacional pela alfabetização na idade certa. 12

Bruna Albieri Cruz da Silva, Josiane Faxina, Michele de Souza Moraes

Capítulo 3: Professoras dos anos iniciais do ensino fundamental e suas relações com o ensino de matemática. 19

Manoel dos Santos Costa, Joemilia Maria Pinheiro Almeida

Capítulo 4: Formação de professores que lecionam matemática para os anos iniciais: Um estudo acerca de conhecimentos das estruturas aditivas e do seu ensino 26

Elys Vânny Fernanda Rodrigues de Oliveira, Angélica da Fontoura Garcia Silva

Capítulo 5: Um estudo sobre as concepções de professores do Ensino básico em relação à Aleatoriedade 36

Marcelo Rivelino Rodrigues

Capítulo 6: Um problema no ensino da matemática: 0 aprendizado das frações 44

Maria Inmaculada Chao Cabanas

Capítulo 7: Uma análise acerca da produção de conjecturas e provas matemáticas de alunos do $8^{\circ}$ ano do ensino fundamental 58

Liana Krakecker, José Luiz Magalhães de Freitas

Capítulo 8: A resolução de problemas no contexto da álgebra elementar: Uma investigação dos saberes e das práticas do professor de matemática de $7^{\circ}$ e $8^{\circ}$ anos do ensino fundamental 68

Valquírio Firmino da Silva, Gilberto Francisco Alves de Melo

Capítulo 9: Identificação da grandeza área em livro didático do 9o ano do Ensino Fundamental numa perspectiva didática-praxeológica. 75

Edmundo Silva Guerra, Marcella Claudia Barbosa da Silva, Jorge Henrique Duarte 


\section{SUMÁrio}

Capítulo 10: Origami: 0 uso como instrumento alternativo no ensino da geometria

Aline Claro de Freitas Abucarma, José Roberto Nogueira

Capítulo 11: Ensino de geometria como temática de uma formação continuada........ 93

Waléria de Jesus Barbosa Soares, Carlos André Bogéa Pereira

Capítulo 12: Resultados Finais de uma atividade diagnóstica sobre conhecimentos geométricos de alunos do $6^{\circ}$ ano do ensino fundamental. 101

Geovana Raquel Pereira da Silva, Luana Cardoso da Silva, Cristiane Fernandes de Souza

Capítulo 13: Ensino da matemática no século XXI: Desafios e possibilidades 109

Maria de Fátima Caldas de Figueirêdo

Capítulo 14: 0 surgimento de um jogo didático e suas contribuições na formação de professores: Decimando

Flávia Streva Nunes, Gabriela Felix Brião

Capítulo 15: Educação financeira nos anos iniciais do ensino fundamental sob o olhar da inclusão 125

Barbara Cristina Mathias dos Santos, Luciana Troca Dantas, Chang Kuo Rodrigues

Capítulo 16: Softwares matemáticos na prática pedagógica: Uma reflexão sobre o uso em escolas públicas.

Ana Cristiane de Sousa, Ruth Brito de Figueiredo Melo

Capítulo 17: Gincana de matemática: Uso de kits educacionais conforme habilidades da Base Nacional Comum Curricular (BNCC) 138

Jerônimo Freire Silva

Autores: 146 


\section{Capítulo 1}

Modelagem matemática na educação básica: Uma proposta de análise do currículo construído na interação do processo de ensino e aprendizagem

\section{Derli Kaczmarek}

Dionisio Burak

Resumo: Este artigo apresenta o projeto de pesquisa de doutorado, inicialmente intitulado Modelagem Matemática: uma análise do currículo construído na interação do processo de ensino e aprendizagem, que tem como objetivo analisar as possibilidades e desafios frente a um currículo construído com o uso da Modelagem Matemática. Pretendemos buscar respostas para saber: "qual é a relação entre o currículo escolar oficial para o $6^{\circ}$ ano do Ensino Fundamental e o currículo construído com o uso da Modelagem Matemática, no âmbito da Educação Matemática?". Para isso, faremos uso das contribuições das pesquisas pós-modernas curriculares a partir dos referenciais teóricos de Doll Jr (1997). Silva (2013), Silveira (2007), entre outros. A Modelagem será desenvolvida de acordo com a concepção de Burak (2010). A metodologia de investigação assumida será de cunho qualitativo. Os sujeitos da pesquisa serão os estudantes de $6^{\circ}$ ano do Ensino Fundamental regular de uma escola pública municipal. Para a coleta de dados serão consideradas as atividades desenvolvidas durante as aulas, vídeos das atividades realizadas, questionários, observações e registros no diário de bordo.

Palavras-chave: Educação Matemática. Modelagem Matemática. Currículo Pós-Moderno.

${ }^{1}$ Artigo apresentado na íntegra no XX EBRAPEM - Encontro Brasileiro de Estudantes de Pós-Graduação em Educação Matemática. 


\section{APRESENTAÇÃO DO PROBLEMA DE PESQUISA}

Indiscutivelmente, quadro de giz e livro didático representam grandes recursos auxiliares da prática docente. Contudo, podemos observar que os estudantes, seduzidos pela era virtual, preferem digitar a escrever, ouvir a fazer leitura e mandar mensagens a falar e interagir. Diante desse cenário, fazer com que a escola desperte o desejo de aprender se torna um grande desafio para aqueles que acreditam que "se a educação sozinha não transforma a sociedade, sem ela tampouco a sociedade muda". (FREIRE, 2000).

Surge então uma dúvida: Como ensinar a Matemática, ciência milenar desenvolvida pelo homem para ajudá-lo na descoberta e conquista do mundo, despertando o fascínio de aprendê-la, numa geração repleta de facilidades e encantos virtuais? Esse é um grande desafio encontrado na prática de muitos docentes. Nesse sentido, estudos e pesquisas têm buscado apontar formas de dinamizar o ensino nas suas diversas áreas. A resolução de problemas, o uso das tecnologias da informação e comunicação, a etnomatemática, a história da matemática, o uso de jogos e a Modelagem Matemática são alguns exemplos de propostas metodológicas que visam à melhoria do ensino e aprendizagem da Matemática e, de acordo com as Diretrizes Curriculares da Educação do Estado do Paraná, deverão fundamentar a prática docente. (PARANÁ, 2008).

Para Burak (2010), a forma de conceber a Modelagem, construída ao longo de sua carreira como docente e pesquisador pode diferir de outros autores e de outras visões de ciência, mas atende aos objetivos de se trabalhar com a Modelagem como uma metodologia de ensino para a Educação Básica. Essa visão é sustentada pelas teorias construtivista, sociointeracionista e de aprendizagem significativa e, em uma visão epistemológica de Ciência que se alinha às perspectivas dos paradigmas: pós-moderno, a partir dos estudos de Santos (2006) e do pensamento complexo, na perspectiva de Morin (2006). Esta maneira de conceber a Modelagem é entendida em uma perspectiva de Educação Matemática, cuja natureza contempla diversas áreas do conhecimento, dentre as quais, além da Matemática, a Psicologia, a Sociologia, a Filosofia, a Antropologia e a Língua Materna, que se alinha aos paradigmas das Ciências Humanas e Sociais.

Na pesquisa de mestrado buscamos, a partir do referencial Vygotskyano, analisar as ações e interações dos estudantes durante a realização das atividades com Modelagem. Observamos, por exemplo, que houve o favorecimento do diálogo reiterando a comunicação como instrumento de mediação entre o social e o individual e, também da troca e colaboração com o outro mais experiente, além da possibilidade de internalização de conceitos através do enfrentamento de situações adversas, da aprendizagem possibilitando o desenvolvimento da sociabilidade e da manifestação da emancipação e da autonomia por meio da escolha do tema, da constituição dos grupos, da construção dos problemas e das estratégias de solução desses problemas. Basicamente, as ações e interações decorrentes da Modelagem Matemática, evidenciaram os postulados de Vygotsky para a criação de "uma escola em que as pessoas possam dialogar discutir, duvidar, questionar e compartilhar saberes. Onde há espaço para as contradições, para a colaboração mútua e para a criatividade". (REGO, 2000, p.118).

Uma das inquietações que nos acompanhou durante a realização das atividades com Modelagem, também pela cobrança dos colegas, diz respeito à questão curricular e, conforme já apontado por Burak e Aragão (2012, p.90), a escolha do tema por parte dos estudantes causa "temor por suscitar dúvida se há matemática no tema e, ainda, qual matemática poderá ser desenvolvida".

Mesmo após vivenciar a aumento do interesse e envolvimento dos estudantes na realização das atividades de Modelagem, era grande o desconforto toda vez que era questionada pelos colegas sobre qual conteúdo estava trabalhando e qual seria o próximo: Quando você vai trabalhar equação de segundo grau? Você sabe que eles precisam desse conteúdo no Ensino Médio!

Sabemos que a preocupação com a apresentação prévia dos conteúdos a serem trabalhados limita consideravelmente as possibilidades de uso da Modelagem na Educação Básica. Por outro lado, conteúdos já estudados pelos estudantes são utilizados atribuindo-lhes muito mais sentido e significado e pode, ainda, surgir a necessidade de que novos conteúdos sejam trabalhados no desenvolvimento das atividades. De forma muito mais expressiva do que numa aula tradicional, a interação entre os próprios estudantes e os estudantes e o professor, possibilita e amplia a percepção sobre as dificuldades individuais e coletivas dos estudantes.

Face ao exposto estabelecemos como questão norteadora da nossa pesquisa de doutorado: qual é a relação entre o currículo escolar oficial para o 6o ano do Ensino Fundamental e o currículo construído com o uso da Modelagem Matemática, no âmbito da Educação Matemática? 


\section{JUSTIFICATIVA}

Em nossa prática percebemos que bimestralmente, trimestralmente ou semestralmente (depende de como a escola distribui o período letivo) o professor precisa apresentar um planejamento prévio dos conteúdos a serem trabalhados. Como professores, planejamos os conteúdos a serem ensinados, definimos os objetivos, os encaminhamentos e a avaliação utilizando os documentos oficiais (Parâmetros Curriculares Nacionais, Diretrizes Nacionais e/ou Estaduais e Municipais e outros), ou seja, fazemos uso de um aparato de documentos técnicos e teóricos com a intenção de cumprir com um currículo destinado a construção do conhecimento para crianças e adolescentes.

O currículo representa, portanto, um instrumento pelo qual a escola pode contribuir para que a realidade do mundo contemporâneo seja refletida e transformada. As indagações presentes nas escolas mostram a consciência de que os currículos não são conteúdos prontos a serem passados aos alunos, mas uma construção e seleção de conhecimentos e práticas produzidas em contextos de dinâmicas sociais, políticas e culturais, intelectuais e pedagógicas. "As indagações revelam o entendimento de que os currículos são orientados pela dinâmica da sociedade". Cabe a nós, como profissionais da Educação, encontrar respostas. (BRASIL, MEC, SEB, 2007, p.9).

Encontrar respostas para nossas indagações é nosso intuito, ainda que elas conduzam sempre a mais questionamentos. E nesse sentido, acreditamos contribuir com as pesquisas voltadas para o processo de ensino e aprendizagem fazendo uso das discussões curriculares pós-modernas para investigar o currículo construído em atividades de Modelagem, na perspectiva da Educação Matemática, a partir da escolha de tema pelos estudantes e do trabalho em grupo. Conforme apontado por Silva (2013, p.231) "as discussões teóricas curriculares pós-modernas restringem-se quase que totalmente à linha de Educação, tendo pouca ou nenhuma repercussão nas investigações em Educação Matemática". A nossa pesquisa se justificará por buscar contribuições teóricas contemporâneas do campo de pesquisa curricular na Educação Matemática, em especial, com o uso da Modelagem, representado um diferencial nos estudos nessa linha.

\section{REVISÃO DE LITERATURA}

Estudos realizados mostram que, a insegurança pela possibilidade de não ter domínio sobre o que pode acontecer (ANASTÁCIO, 1990; BARBOSA, 2001; BURAK, 1987); a preocupação em cumprir o conteúdo (ANASTÁCIO, 1990; BURAK, 1987; BURAK, 1992; DIAS, 2005; FIDELIS, 2005; LUZ, 2003; MARTINELLO, 1994); a preocupação com a reação dos pais (BARBOSA, 2001; BURAK, 1992); a insegurança diante do novo (BURAK, 1987; BURAK, 1992; CALDEIRA, 1998; DIAS, 2005; GAVANSKI, 1995; GAZZETTA, 1987) e com os objetivos diferentes dos da instituição (FIDELIS, 2005; ROMA, 2003) são alguns dos "principais pontos negativos explicitados pelos professores cursistas para justificar a não adoção da Modelagem Matemática nas suas práticas de sala de aula, ou suas dúvidas sobre a mesma". (SILVEIRA, 2007, p.100101). Em nosso entendimento, esses pontos negativos se relacionam diretamente com a preocupação sobre o conteúdo curricular a ser trabalhado com os estudantes.

Em análises realizadas na busca de elaborar Uma Metacompreensão Da Modelagem Matemática Na Educação Matemática, Klüber (2012) questiona: Em que sentido se deve assumir a Modelagem Matemática? Condicionando-a à estrutura escolar e às concepções vigentes ou contrapondo-se a elas, para chegar a outras compreensões de escola e de currículo? (KLUBER, 2012, p.149). Ainda segundo o autor, "Ao assumir a Modelagem Matemática na Educação Matemática, mudanças curriculares se impõem". (idem, p.154).

Os pontos citados anteriormente e a experiência vivida com a utilização da Modelagem sinalizam que, a preocupação com o cumprimento dos conteúdos curriculares representa um campo conflitivo no desenvolvimento da Modelagem que necessita ser mudado. Gamboa (2012, p. 133) nos lembra de que para entender a escola é necessário investigar sua dinâmica e diagnosticar suas possibilidades de mudança. "Assim, a pesquisa se converterá num instrumento eficiente para a ação inovadora ou transformadora da educação".

Entendemos ser importante vencer a barreira epistemológica e a forma estrutural de organização do sistema escolar atual no trabalho que envolve a Modelagem na Educação Matemática, com vistas a ganhos pedagógicos. Tal desafio encontra embasamento nos documentos oficiais. Os Parâmetros Curriculares Nacionais de Matemática - PCNs foram elaborados em consonância com a Lei de Diretrizes e Bases da Educação, Lei 9.394/96 - LDB que preconiza, para a formação básica do cidadão no que se refere ao Ensino Fundamental, "o desenvolvimento da capacidade de aprender, tendo como meios básicos o pleno domínio da leitura, da escrita e do cálculo" (BRASIL, 2002, p.37) e amplia essas prerrogativas para que esses conhecimentos sejam consolidados no Ensino Médio. 
No que se referem aos princípios norteadores, os PCN's enunciam que a Matemática é importante para a construção da cidadania e deve ser democratizada pelos docentes de modo que a aprendizagem ocorra pelo caminho da construção e compreensão. Para isso, a seleção e o tratamento dos conteúdos não devem ser encaminhados linearmente, a partir da lógica interna da Matemática, mas considerando os aspectos filosóficos, científicos e sociais referentes ao contexto de sua construção.

Os PCN’s indicam a Resolução de Problemas, a História da Matemática e as Tecnologias da Comunicação como caminhos para "fazer Matemática" na sala de aula. Apontam também a importância de estabelecer conexões entre os blocos de conteúdos, entre a Matemática e outras áreas do conhecimento e suas relações com o cotidiano (Meio Ambiente, Saúde, Pluralidade Cultural, Ética etc).

Dessa forma, um desafio que se apresenta é o de identificar quais conhecimentos, competências, hábitos e valores são socialmente relevantes e contribuem para o desenvolvimento intelectual dos estudantes. Nesse contexto, as investigações desenvolvidas em áreas como a da Modelagem e da Etnomatemática, também são possibilidades que podem e devem ser consideradas.

A Modelagem Matemática tem se ampliado nas discussões entre educadores matemáticos, e é considerada uma tendência metodológica em Educação Matemática nas próprias Diretrizes Curriculares do Estado do Paraná - DCE, 2008. De acordo com este documento, os conteúdos de matemática devem ser abordados por meio da resolução de problemas, modelagem matemática, mídias tecnológicas, etnomatemática, história da matemática e investigação matemática, que irão fundamentar a prática docente de modo que essas tendências metodológicas "[...] têm grau de importância similar entre si e complementam-se umas às outras." (PARANÁ, 2008, p. 63).

No que se refere ao currículo, as abordagens teóricas curriculares contemporâneas são amplamente debatidas por muitos educadores, contudo "não observamos a mesma proporção de pesquisas quando olhamos as realizadas em Educação Matemática, principalmente no Brasil”. (SILVA, 2013, p. 205).

Para compreendermos as mudanças ocorridas na concepção de currículo, Silva (2013) discute as teorias tradicionais; as teorias críticas e as teorias pós-críticas. Segundo o autor, em relação ao currículo, ao contrário da teoria crítica que surgiu como um questionamento da teoria tradicional, a teoria pós-crítica surgiu pelas contribuições decorrentes dos estudos pós-estruturais do currículo que iniciaram na década de 1970 e ganharam força na década seguinte. A valorização do conhecimento matemático historicamente construído ganhou, dessa forma, sustentação nas teorias pós-críticas, mais especificamente, no conceito de currículo pós- moderno. A partir dessas discussões, Silva (2013) apresenta as principais características do período moderno e pós-moderno:

Quadro 1: Principais características do currículo no modernismo e no pós-modernismo

\begin{tabular}{|c|c|}
\hline Modernismo & Pós-Modernismo \\
\hline Fins são externos ao processo. & Fins surgem do próprio processo. \\
\hline Ênfase na descoberta, não na criação. & Ênfase na criatividade, não na descoberta. \\
\hline $\begin{array}{l}\text { Ordenamento linear: objetivos preestabelecidos, } \\
\text { seleção e direcionamento de experiências, avaliação. }\end{array}$ & $\begin{array}{c}\text { Disposição em rede: objetivos, seleção e direcionamento de } \\
\text { experiências são hipóteses que deverão ser reconstruídas e } \\
\text { negociadas durante o processo. A avaliação direciona esta } \\
\text { reconstrução e negociação. }\end{array}$ \\
\hline $\begin{array}{c}\text { Distinção entre objetivos educacionais e objetivos } \\
\text { curriculares. }\end{array}$ & $\begin{array}{l}\text { Os objetivos educacionais e curriculares são sintonizados e } \\
\text { direcionados para a comunidade na qual serão aplicados. }\end{array}$ \\
\hline O conhecimento é transmitido, transferido. & O conhecimento é transformado. \\
\hline
\end{tabular}

Percebemos uma grande similaridade entre as exigências atuais, em relação ao planejamento escolar, com as características do modernismo, ainda que o discurso educacional seja voltado às características do pósmodernismo. No entanto, na realização da Modelagem com nossos estudantes vivenciamos as peculiaridades de um currículo criador e desenvolvedor. Para Doll Jr (1997, p.29) estes são os diferenciais de um currículo do pós-modernismo, ou seja, um currículo "não em termos de conteúdos ou materiais (uma "pista-a-ser-corrida"), mas em termos de processo, um processo de desenvolvimento, diálogo, investigação, transformação",

Em estudos envolvendo o cotidiano escolar e os currículos reais, Ferraço (2000) percebe na complexidade da dinâmica de produção de conhecimentos o cruzamento das sombras modernas e pós-moderna. A partir 
de suas análises, o autor atenta para a extrema necessidade de pensar e teorizar o currículo não somente a partir da perspectiva da prescrição, mas especialmente a partir do que é de fato realizado nas salas de aula. 0 currículo prescritivo enseja uma prática educacional de abordagem totalizadora e homogênea, por outro lado, os currículos reais, realizados, almejam uma abordagem plural, multirreferencial, que considere também o imprevisto como seu determinante.

Corroboramos com os autores sobre a necessidade da ampliação dos estudos à cerca das questões curriculares no campo da Educação Matemática e, nesse sentido desejamos fazê-lo sob a ótica da Modelagem Matemática. Desta forma, estaremos contribuindo para "um processo que chamamos de desconstrução-reconstrução necessário para a sistematização e consolidação desta subárea da Educação Matemática em um campo de pesquisa frutífero e com identidade própria". (SILVEIRA, 2007, p.110). Para isso, entendemos que as discussões a respeito das características de um currículo pós-moderno, tal como apresentado pelo autor, podem trazer grandes contribuições para preenchermos as lacunas que alimentam a insegurança dos professores na persistência do cumprimento de um currículo "engessado" em detrimento das possibilidades enriquecedoras advindas do uso da Modelagem.

Vale ressaltar que as pesquisas sobre a Modelagem Matemática sugerem a sua implementação curricular nos diversos níveis de ensino, contudo não encontramos nenhuma pesquisa que apresente uma abordagem sobre o currículo, na perspectiva pós-moderna, construído no interior da Modelagem, especialmente na Educação Básica.

No estudo realizado por Siveira (2007) sobre Modelagem Matemática na educação no Brasil, o autor aponta a falta de subsídios para que possamos entender por que, mesmo mostrando abertura e otimismo quanto aos trabalhos, poucos professores a efetivam em sala de aula. Nosso pensamento converge com o autor a respeito de que rumos mais definidos sejam traçados, somando esforços em todos os níveis da educação brasileira, "Aí sim, acreditamos que, à medida que o professor tomar conhecimento de novas formas de diversificar a sua prática pedagógica, ele terá mais tranquilidade e coerência para decidir se quer ou não aderir". (SILVEIRA, 2007, p.104).

\section{PROCEDIMENTOS METODOLÓGICOS}

Com vistas a desvelar "qual é a relação entre o currículo escolar oficial, para o 6o ano do Ensino Fundamental e o currículo construído com o uso da Modelagem Matemática, no âmbito da Educação Matemática?" elencamos como objetivo central de nossa pesquisa avaliar as possibilidades e desafios frente a um currículo construído com o uso da Modelagem Matemática.

Como objetivos específicos, pretendemos comparar e ponderar sobre os conteúdos matemáticos propostos no currículo regular de Matemática do 6ํAno do Ensino Fundamental e o currículo construído e mediado pelas atividades de Modelagem Matemática na Educação Matemática, a partir de temas de escolhas dos estudantes; e, apontar e ponderar a natureza dos possíveis ganhos com o uso da Modelagem para o processo de ensino e aprendizagem da Matemática.

Para a coleta de dados serão utilizadas as atividades realizadas pelos estudantes, além de vídeos, questionários e registros realizados pela professora-pesquisadora durante as aulas de matemática utilizando-se a Modelagem Matemática como metodologia de ensino. Os sujeitos da pesquisa serão os estudantes de 6ํano do Ensino Fundamental de uma escola pública da rede municipal de ensino de Araucária.

A metodologia de investigação é de cunho qualitativo, pois compartilha as características apresentadas por Bogdan \& Biklen (1994), entre as quais, acontece em um ambiente natural; o investigador vai ao local dos participantes para recolher os dados com mais detalhe; é interpretativa, descritiva e indutiva, pois o investigador faz uma interpretação dos dados, descreve os locais, os participantes e analisa os dados para configurar temas ou categorias e retirar conclusões; não há a preocupação em arranjar dados ou evidência para provar ou rejeitar hipóteses e é significativa - é uma preocupação essencial na abordagem qualitativa. 0 investigador está preocupado em saber como diferentes pessoas fazem sentido ou dão significado às suas vidas e quais são as perspectivas pessoais dos participantes. 0 investigador qualitativo preocupa-se mais com o processo do que com os resultados.

Nesse sentido, nossa pesquisa que está em fase de coleta de dados, visa contribuir com as discussões curriculares no processo de ensino e aprendizagem de Matemática na Educação Básica. Pretendemos dar vazão e ampliar os horizontes pesquisados da Modelagem Matemática, considerando a possibilidade de superação da preocupação com o cumprimento do conteúdo curricular previsto, por meio da participação 
dos estudantes na construção do mesmo. Dessa forma, propomos contribuir com as reflexões sobre a organização curricular do ensino de Matemática à luz das possibilidades decorrentes da Modelagem Matemática.

\section{REFERÊNCIAS}

[1] Brasil. Parâmetros Curriculares Nacionais: matemática. Secretaria de Educação Fundamental. Brasília, 1997, $142 \mathrm{p}$.

[2] Brasil. Lei de Diretrizes e Bases da Educação - Lei 9.394/1996. Apresentação Carlos Roberto Jamil Cury. 5. ed. Rio de Janeiro: DP\&A, 2002.

[3] Burak, D. Modelagem Matemática: ações e interações no processo de ensino-aprendizagem. Tese de Doutorado, FE/UNICAMP. Campinas, 1992.

[4] Burak, D. ; Aragão, R, M .R de. . A modelagem matemática e relações com a aprendizagem significativa. - 1.ed. - Curitiba, PR: CRV, 2012, 129p.

[5] Burak, D. Uma perspectiva de modelagem matemática para o ensino e a aprendizagem da matemática. In: BRANDT, Célia Finck; BURAK, Dionísio; KLÜBER, Tiago Emanuel (Org.). Modelagem Matemática: Uma perspectiva para a Educação Básica. Ponta Grossa: Uepg, 2010. Cap. 1. p. 15-38.

[6] Burak, D.; Klüber, T. E. Educação Matemática: contribuições para a compreensão de sua natureza. Acta Scientiae (ULBRA), v.10, p. 93-106, jul-dez., 2008.

[7] Doll JR., W. E. Currículo: uma perspectiva pós-moderna. Porto Alegre: Artes Médicas, 1997.

[8] Ferraço, C. E. Cotidiano escolar e currículos reais.: sobre a complexidade das redes de saberes produzidas e articuladas nas salas de aula. (DASE/CP/UFES). Disponível em: <http://23reuniao.anped.org.br/trabtit2.htm>. Acesso em 02 fev. 2015.

[9] Freire, P. Pedagogia da autonomia: saberes necessários à prática educativa. São Paulo: Paz e Terra, 1996.

[10] Gamboa, S. S. Pesquisa em educação: métodos e epistemologia. 2. ed. - Chapecó: Argos, 2012.

[11] Kaczmarek, D. Modelagem no ensino da Matemática: Um viés na ação e interação do processo de ensino e aprendizagem. Dissertação (Mestrado em Educação). Universidade Estadual de Ponta Grossa, UEPG. Ponta Grossa, PR, 2014.

[12] Klüber, T. E. Uma metacompreensão da modelagem matemática na educação matemática. Tese (Doutorado). Universidade Federal de Santa Catarina, UFSC. Florianópolis, SC, 2012.

[13] Klüber, T.E.; Burak, D. A Fenomenologia e suas contribuições para a Educação Matemática. Práxis Educativa, Ponta Grossa, PR, v. 3, n. 1, p. 95 - 99 jan.-jun. 2008.

[14] Paraná. Diretrizes Curriculares da Educação Básica: Matemática. Secretaria do Estado da Educação do Paraná. Departamento da Educação Básica. Paraná, 2008. Disponível em: <http://www.educadores.diaadia.pr.gov.br/arquivos/File/diretrizes/dce_mat.pdf>>. Acesso em 24 jan 2015.

[15] Rego, T.C. Vygotsky: uma perspectiva histórico-cultural da educação. Petrópolis, RJ: Vozes, 10. ed., 2000.

[16] Silva, M. A. Contribuições Contemporâneas para as Discussões Curriculares em Educação Matemática: a teoria crítica pós-moderna. ALEXANDRIA Revista de Educação em Ciência e Tecnologia, v.6, n.1, p. 205-233, abril 2013.

[17] Silveira, E. Modelagem Matemática em Educação no Brasil: entendendo o Universo de Teses e Dissertações. Curitiba, 2007, 197p. Dissertação (Mestrado em Educação) - Universidade Federal do Paraná, Curitiba, 2007. 


\section{Capítulo 2}

Alfabetização matemática na perspectiva do letramento: Alguns apontamentos a partir do pacto nacional pela alfabetização na idade certa

\section{Bruna Albieri Cruz da Silva}

Josiane Faxina

Michele de Souza Moraes

Resumo: A alfabetização matemática trabalhada nos três primeiros anos do Ensino Fundamental assume relevante papel, pois servirá como base para a aprendizagem nos anos seguintes de escolarização. Nessa perspectiva, o presente artigo tem por objetivo analisar e discutir alguns apontamentos trazidos pelo Pacto Nacional pela Alfabetização na Idade Certa quanto a propostas de utilização de recursos como os diversos gêneros textuais, jogos e resolução de problemas, na busca por uma alfabetização matemática na perspectiva do letramento. Após uma análise documental do material apresentado pelo programa, verificou-se que para uma alfabetização matemática na perspectiva do letramento, os diversos gêneros textuais podem ser um forte aliado para a compreensão da função social da matemática. 0 uso da resolução de problemas, bem como dos jogos, também contribui para uma aprendizagem com significações próprias, que possibilitam ao aluno estabelecer relações entre os mais variados conhecimentos matemáticos, assim como as demais áreas curriculares.

Palavras-chave: alfabetização matemática; letramento; PNAIC. 


\section{INTRODUÇÃO}

É fato que a Matemática tem papel fundamental no desenvolvimento da capacidade intelectual do ser humano, pois possibilita a estruturação do pensamento, desenvolvendo o raciocínio lógico e dedutivo, capacitando-o para a resolução de problemas, além de funcionar como instrumento essencial para a construção de conhecimentos em outras áreas curriculares. (BRASIL, 1997).

Conceitos matemáticos estão em situações do cotidiano e são fundamentais para a convivência em sociedade. Por esse motivo, o ensino da Matemática e o entendimento desses

conceitos tornam-se fundamentais para a interação social, tornando-se tão importante quanto as demais áreas curriculares que se constituem direitos de aprendizagem do aluno.

No entanto, o ensino desta disciplina parece ser um desafio para muitos professores, pois geralmente é trabalhada de forma descontextualizada ou visando somente o ensino do sistema de numeração decimal e as operações aritméticas fundamentais, não garantindo a alfabetização matemática. Para que isso ocorra, é necessário o desenvolvimento de todos os eixos estruturantes de ensino da Matemática,

[...] como as relações com o espaço e as formas, processos de medição, registro e uso das medidas, bem como estratégias de produção, reunião, organização, registro, divulgação, leitura e análise de informações, mobilizando procedimentos de identificação e isolamento de atributos, comparação, classificação e ordenação. (BRASIL, 2014, p.27)

O Pacto Nacional pela Alfabetização na Idade Certa (PNAIC) é um programa lançado pelo Governo Federal de grande importância para o ciclo de alfabetização. Tem como função contribuir na formação dos professores alfabetizadores, nas diversas áreas do conhecimento. Lançado em novembro de 2012, contou com a assinatura de adesão de 5240 municípios e dos 27 estados da federação, firmando um compromisso formal entre Governo Federal, Distrito Federal, estados, municípios e sociedade, visando assegurar que todas as crianças estejam alfabetizadas até os 8 anos de idade, ao final do 3ํano do Ensino Fundamental. O programa desenvolve ações que incluem a formação continuada de professores alfabetizadores, distribuição de materiais pedagógicos pelo Ministério da Educação (MEC) e aplicação de avaliações sistemáticas.

No ano de 2014 foi lançado o PNAIC de Matemática, trazendo em seus cadernos, a ideia de Alfabetização Matemática na perspectiva do letramento, em consonância com a proposta contida no material de linguagem.

Dessa forma, esse estudo tem por objetivo analisar a proposta trazida pelo PNAIC, e apontar as diretrizes de trabalho trazidas pelo material, para alcançar a meta da alfabetização matemática na perspectiva do letramento.

Para isso, foi realizada uma análise documental, a partir dos cadernos de formação do PNAIC/Matemática.

\subsection{PNAIC E A ALFABETIZAÇ̃̃o MATEMÁTICA NA PERSPECTIVA DO LETRAMENTO}

Dentre as ações desenvolvidas pelo PNAIC, a formação continuada do professor alfabetizador é o foco principal do programa. Esse processo de formação é organizado por meio de um curso ministrado por Orientadores de Estudos, e está organizado em oito unidades: ganização do Trabalho Pedagógico; Quantificação, Registros e Agrupamentos; Construção do Sistema de Numeração Decimal; Operações na Resolução de Problemas; Geometria; Grandezas e Medidas; Educação Estatística e Saberes Matemáticos e outros Campos do Saber; além dos cadernos de referência Apresentação, Educação Matemática do Campo; Educação Inclusiva e Jogos. Cada unidade possui um material de apoio organizado em cadernos de formação. Todos os temas abordados pelo PNAIC são tratados na perspectiva do letramento.

De acordo com Soares (2000, p. 47), o termo alfabetização refere-se à "ação de ensinar/aprender a ler e a escrever", enquanto letramento é o "estado ou condição de quem não apenas sabe ler e escrever, mas cultiva e exerce as práticas sociais que usam a escrita" (SOARES, 2000, p. 47). Assim, os termos Alfabetização e Letramento representam conceitos distintos, porém, indissociáveis. Para Soares,

A alfabetização desenvolve-se no contexto de e por meio de práticas sociais de leitura e escrita, isto é, através de atividades de letramento, e este, por sua vez, só se pode desenvolver no contexto da e por meio da aprendizagem das 
relações fonema-grafema, isto é, em dependência da alfabetização. (SOARES, 2000, p. 14.)

Nesse sentido, para estar alfabetizado e letrado, o sujeito deve ser capaz de inserir-se e participar ativamente do mundo letrado através da capacidade de ler e escrever em diferentes situações sociais, e para que isso aconteça:

[...] não basta apenas o domínio dos conhecimentos relacionados à linguagem: é necessário também um amplo domínio de outras disciplinas como a matemática, no qual os números e o sistema de numeração decimal são fundamentais, mas não são os únicos aspectos que devem ser abordados na escola. (BRASIL, 2014, p. 10).

No documento de apresentação do Pacto (BRASIL, 2012), a proposta trazida pelo programa é de que nos anos iniciais do Ensino Fundamental a tarefa primordial da escola seja ampliar o universo de referências culturais das crianças e contribuir para desenvolver e aprofundar suas práticas sociais colocando em ação seu conhecimento adquirido. Além de dominar o sistema de escrita alfabética, é necessário que a criança compreenda os diversos usos e funções da língua. Quem escreve, não escreve isoladamente, mas sim em um contexto e com uma finalidade. Ortega e Parisotto $(2016$, p. 56) afirmam que "a alfabetização, na perspectiva do letramento, inclui as diferentes vivências dos indivíduos inseridos numa determinada cultura".

Todo ser mano está envolvido em um meio social e se constitui conforme esse contexto. Com o passar do tempo, os sujeitos estabelecem uma convivência através de trocas de experiências, adquirindo conhecimentos principalmente por meio da linguagem. De acordo com Vigotski (1998, apud LUVISON e GRANDO, 2012), a linguagem é social. "Suas funções iniciais são a comunicação, a expressão e a compreensão, que estão ligadas ao pensamento. A compreensão é estabelecida através das produções histórico-culturais que são organizadas e expressas pelas palavras e pelos textos" (LUVISON e GRANDO, 2012, p. 7).

Assim, por meio de diferentes textos, os alunos podem se apropriar de diferentes linguagens, inclusive, a linguagem matemática. Neste sentido, o trabalho com os gêneros textuais faz com que os alunos não só aprendam a "codificar e decodificar" palavras e textos, mas também façam uso da linguagem considerando os diferentes contextos nos quais estão inseridos, e assim entendam-se como sujeitos políticos e possuidores de cultura. Para agir ativamente na sociedade e para compreender a função social dos gêneros textuais é necessário

o desenvolvimento e integração de todas as áreas curriculares: Língua Portuguesa, Arte, Educação Física, História, Geografia, Matemática, Ciências. (BRASIL, 2012), pois não vivemos em um mundo compartimentalizado, mas sim integrado a todos os componentes curriculares e ao cotidiano das pessoas.

Os diferentes gêneros textuais podem ajudar o sujeito a compreender e apreender conceitos, desenvolvendo e transformando seus pensamentos. Quando os alunos expressam seu pensamento em linguagem matemática, compartilhando suas hipóteses, fazendo analogias

e reinterpretando conceitos, há uma troca, uma reflexão constante em torno das textualizações, o que é uma fase importante para o seu desenvolvimento (LUVISON e GRANDO, 2012).

Os gêneros também podem contribuir para aprendizagem matemática na perspectiva do letramento, pois os textos em língua materna que fazem parte das práticas sociais dos alunos, como os

textos informativos, explicativos, narrativos, entre outros, podem conter escritas próprias da linguagem Matemática, como porcentagens, tabelas, gráficos, algarismos romanos, números na forma

decimal, na forma fracionária, etc. Assim, para que no processo de alfabetização e letramento, o aluno possa ler, compreender e ser um leitor crítico desses textos, é necessário que a leitura matemática seja

[...] as práticas sociais envolvendo quantificação, medição, orientação, ordenação ou classificação compõem os modos de usar a língua escrita e são

por eles constituídas, não só porque representações matemáticas aparecem nos textos escritos ou porque nossa herança cultural nos legou modos escritos de fazer Matemática, mas porque a própria cultura escrita, que permeia e constitui as práticas matemáticas das sociedades grafocêntricas, é, em geral, permeada 
também por princípios calcados numa mesma racionalidade, que forja ou parametriza essas práticas matemáticas e que é por elas reforçada. (p.9)

Durante as aulas, conceitos matemáticos vão sendo construídos por meio de investigações e problematizações, e assim, uma linguagem matemática vai se constituindo com a finalidade de comunicar ideias. A escrita nas aulas de matemática torna-se essencial para o registro e comunicação dessa aprendizagem.

De acordo com o material (BRASIL, 2014, p. 19-20):

0 registro pode ser realizado por meio de diferentes gêneros textuais, assumindo sentidos diversos no contexto de aulas de Matemática: registro reflexivo para os alunos, registro de comunicação aos colegas e professor, registro do processo para constituir memória, registro como forma de sistematização, registro como apropriação de uma linguagem, registro como forma de comunicação da resolução e/ou formulação de um problema.

Porém, esses registros devem ter um sentido dentro do contexto do problema, ou da atividade proposta, assim, ele acontece por uma necessidade. Em uma das sugestões de atividades presentes no material, é proposto que os alunos escrevam uma carta sobre suas descobertas a respeito da resolução de um problema, e as troquem com outra sala de aula do mesmo ano. Nessa carta, os alunos irão relatar suas hipóteses e argumentos para a resolução. Dessa forma considera-se a função social desse registro ao mesmo tempo que se define a sua configuração linguística.

Nos cadernos de formação lançados pelo Pacto, a alfabetização matemática é entendida como um "instrumento para a leitura do mundo" (BRASIL, 2014, p. 5), que possibilita a construção de conhecimentos que permitem ao aluno entender e resolver problemas em diferentes contextos. 0 importante no processo de ensino da matemática nos anos iniciais, de acordo com o Pacto, é oferecer às crianças oportunidades para identificarem relações numéricas e aplicarem-nas em diferentes situações de forma cada vez mais elaboradas e complexas (BRASIL, 2014).

Em comparação com o termo "letrado" especificado por Soares (2000) como a condição da criança não apenas saber ler e escrever, mas saber fazer uso social da leitura e da escrita, Vece, Mocrosky e Paulo (2014) na mesma perspectiva, explicam a necessidade de a criança estar "numerada":

[...] entende-se como "numerado" quem, além da elaboração do conhecimento e da linguagem matemática, engaja-se com autonomia em situações que envolvam o domínio de dados quantitativos, quantificáveis e, sobretudo, compreende as diversas funções e usos dos códigos numéricos em diferentes contextos". (VECE, MOCROSKY E PAULO, 2014, p. 58).

Nessa perspectiva, Spinillo (2005) mostra a necessidade de ensinar matemática de forma a tornar os indivíduos numeralizados: "Na realidade, estamos cercados por um ambiente de números e quantidades, e para funcionarmos de maneira apropriada e eficiente nesse ambiente é necessário que sejamos numeralizados". (p. 83). Assim, pode-se afirmar que a criança numeralizada é capaz de pensar matematicamente sobre variadas situações. Isso requer que ela mobilize seus conhecimentos sobre os sistemas numéricos, convenções, técnicas e procedimentos e estabeleça relações e conexões nos mais variados contextos da vida humana.

Diante do exposto, trabalhar com a educação matemática na perspectiva do letramento, é oferecer à criança subsídios para que ela compreenda e faça uso de conceitos matemáticos em suas relações sociais e em situações do cotidiano. 0 material do Pacto foi elaborado com o intuito de contribuir com a formação do professor alfabetizador, fornecendo uma base teórica, sugestões de práticas e organização do trabalho docente, que visam colaborar para a concretização da aprendizagem dos alunos.

Para que isso aconteça, o aluno deve estar situado em um ambiente de atividade matemática que o ajude a aprender, não somente codificando e decodificando os símbolos matemáticos, mas também realizando variadas leituras de mundo, levantando conjecturas e validando-as, argumentando e justificando procedimentos (NACARATO, PASSOS e GRANDO, 2014).

0 material então, sugere que a sala de aula deve ser vista:

[...] como um ambiente de aprendizagem pautado no diálogo, nas interações, na comunicação de ideias, na mediação do professor e, principalmente, na intencionalidade pedagógica para ensinar de forma a ampliar as possibilidades 
das aprendizagens discentes e docentes. (NACARATO, PASSOS e GRANDO, 2014, p. 6).

Assim, a sala de aula deve ser constituída como um ambiente facilitador da aprendizagem, de apropriação da leitura e da escrita da língua materna, como também da linguagem matemática. Dessa forma, sugere-se que a sala de aula contenha materiais impressos que ajudem a criança a reconhecer a função social da leitura e da escrita, assim como a presença de materiais que contribuam para o reconhecimento da função social da matemática, como gráficos, tabelas, informações numéricas, entre outros.

Assim, a sala de aula deve ser constituída como um ambiente facilitador da aprendizagem, de apropriação da leitura e da escrita da língua materna, como também da linguagem matemática. Dessa forma, sugere-se que a sala de aula contenha materiais impressos que ajudem a criança a reconhecer a função social da leitura e da escrita, assim como a presença de materiais que contribuam para o reconhecimento da função social da matemática, como gráficos, tabelas, informações numéricas, entre outros.

A seguir, destacaremos algumas práticas sugeridas pelo material do PNAIC, para o trabalho com a Alfabetização Matemática e Letramento.

\section{RESOLUÇÃO DE PROBLEMAS E JOGOS NA PERSPECTIVA DO LETRAMENTO}

No contexto do Ciclo de Alfabetização, as brincadeiras e jogos são fundamentais para o desenvolvimento do aluno, pois deve-se considerar que tratam-se de crianças de 6 a 8 anos de idade. Além dos diversos benefícios trazidos por essas atividades lúdicas, elas podem se constituir em uma boa oportunidade para a alfabetização e letramento. Os registros matemáticos podem ser explorados na forma de tabelas de pontuação, regras, gráficos com as brincadeiras favoritas dos alunos etc.

Para Luvison e Grando (2012, p. 8):

[...] o jogo é um problema em movimento. [...] Ao jogar, os alunos encontram sentidos e, ao mesmo tempo, mostram desejo de brincar e solucionar um problema, o que lhe traz significado e, ao mesmo tempo, a aproximação com seu próprio contexto. A brincadeira e o jogo estão, culturalmente, impregnados na criança. Assim, o jogo torna-se desejado, o que não ocorre muitas vezes com a resolução de problemas. Porém, ao atrelar o desejo pelo jogo ao contexto da resolução de problemas, esta pode adquirir maior significado pois, "após brincar, a busca por aperfeiçoar o jogo e refletir sobre novas estratégias está relacionada à vitória do jogador. (LUVISON e GRANDO, 2012, p. 9).

Quando a utilização dos jogos em sala de aula está amparada num contexto onde os

objetivos estão claramente definidos pelo professor, há a oportunidade de o aluno desenvolver a capacidade de reflexão, argumentação, análise entre outras atitudes como ganhar e perder.

A escolha pelos jogos no ensino da matemática deve ser criteriosa, relacionando-os com os conteúdos e conceitos a serem desenvolvidos. Por outro lado, também pode-se considerar que os jogos, de modo geral, promovem um senso crítico e investigador ajudando no raciocínio lógico da criança.

Ao assumir uma postura de sujeito motivador e se tornando parte do processo investigativo junto com seus alunos, o professor torna-se um elemento importante no jogo. Conhecendo o funcionamento do jogo, suas possibilidades para o desenvolvimento de ideias e conceitos matemáticos, assim como as estratégias adotadas pela criança para atingir a meta proposta, o professor poderá explorar de maneira mais significativa as possibilidades didáticas do jogo em questão.

O material do PNAIC (BRASIL, 2014) aponta reflexões e propostas de trabalho para o professor dos anos iniciais com jogos nas aulas de matemática, numa concepção de trabalho no qual o planejamento é fundamental e privilegia a construção do saber. 0 jogo assume um caráter de desenvolvimento das habilidades e conceitos e se aproxima das características do trabalho com resolução de problemas, onde permite-se ao aluno elaborar estratégias, pensamentos e ideias inerentes ao conteúdo em questão.

A formulação e resolução de problemas também são de extrema importância para a compreensão matemática e o letramento, pois o processo de descobertas para a solução feita pelo aluno é fundamental para a efetivação e significação da aprendizagem matemática

Em todo o material do Pacto, é evidente o destaque dado ao trabalho com resolução de problemas em sala de aula, um dos maiores desafios do professor dos anos iniciais, já que os alunos estão iniciando a prática 
de leitura. Além do que, desenvolver práticas pedagógicas onde é preciso respeitar o modo de pensar de cada aluno, permitir que cada um tenha oportunidade de formular suas próprias estratégias, se tornam aspectos a serem superados pelo professor que está acostumado a ensinar procedimentos e técnicas.

Muitas vezes a atividade matemática escolar é organizada apenas a partir de exercícios nos quais a meta é aprender a realizar cálculos (mentais e escritos) e a usar algoritmos, de modo a tornar a rotina na sala de aula marcada por intermináveis exercícios sem significado para os alunos. (GUERIOS, AGRANIONIH, ZIMER, 2014, p. 7)

As autoras também afirmam que por muito tempo os problemas matemáticos foram utilizados como forma de treino para procedimentos e técnicas. Nessa perspectiva o aluno fica limitado a realização de um passo a passo sem a possibilidade de construir ou consolidar os conceitos pertinentes ao conteúdo trabalhado.

\section{Resolver algoritmos em problemas matemáticos é uma ferramenta importante para a}

busca da solução, porém não garante ao aluno a compreensão do conceito em questão, bem como o desenvolvimento de ideias e estratégias para a resolução.

Nesse sentido, do mesmo modo que os princípios e ideias matemáticas vão sendo construídos através da resolução de problemas por meio de investigações, problematizações e descobertas, uma linguagem matemática também vai sendo compreendida e produzida afim de entender e expressar estas descobertas, ou mesmo refletir e compartilhar as estratégias escolhidas para a resolução.

Na perspectiva do letramento, é essencial que o aluno tenha a capacidade de identificar e reconhecer o papel que a matemática representa, descobrindo, relacionando e inferindo significado próprio às suas descobertas. 0 trabalho com resolução de problemas tem os espaços necessários para essas ações acontecerem com sucesso, pois os conceitos poderão ser construídos em torno de uma questão que seja desafiadora e estimulante ao aluno.

Nessa visão, o professor tem uma gama de possibilidades de trabalho para desenvolver no ensino da matemática. Uma proposta que o material do Pacto traz é a diversidade de gêneros textuais dentro dessa perspectiva de resolução de problemas. Tanto nos problemas que o professor apresenta a seus alunos, no qual deve garantir uma rica variedade, bem como na própria elaboração feita pelos alunos, em forma de registros das suas atividades. A intervenção do professor nesse processo atenderá às necessidades dos alunos para que estes se apropriem do vocabulário específico da matemática, com o intuito de comunicar suas descobertas.

"As várias formas de registro possibilitam a produção de sentidos próprios do objeto matemático pelas crianças, a produção de significados compartilhados entre alunos e o professor no contexto de aulas e a reflexão do professor sobre sua prática". (BRASIL, 2014, p. 22).

\section{CONSIDERAÇÕES FINAIS}

As práticas de ensino da matemática têm buscado cada vez mais superar ações que se preocupam apenas com a transmissão de técnicas e procedimentos em sala de aula. A preocupação é maior quando se trata do ciclo de alfabetização, pois além de desenvolver os conceitos básicos da matemática, também servirá de base para a consolidação da aprendizagem nos anos seguintes de escolarização.

É preciso garantir aos alunos dos anos iniciais, atividades e propostas que possibilitem a eles a construção de sentido na aprendizagem de cada conceito matemático. Nesse sentido, os diversos gêneros textuais pode ser um forte aliado para a contextualização de situações matemáticas que permitam aos alunos a compreensão da função social da matemática. Assim, a alfabetização na perspectiva do letramento garante reflexões e norteamento aos professores quanto às práticas e habilidades que os alunos devem adquirir.

Consideramos que o material analisado no presente trabalho, apresenta apontamentos que levam os professores a inserir em sua prática pedagógica recursos que permitem o ensino da matemática numa visão na qual o aluno necessita construir os próprios conceitos através de problematizações.

0 uso da resolução de problemas, bem como dos jogos, desafia o aluno a colocar em questão seus saberes na busca de estratégias, formulações de hipóteses e consolidação das mesmas. Desse modo a aprendizagem será desenvolvida com significações próprias, possibilitando ao aluno estabelecer relações entre os mais variados conhecimentos matemáticos, assim como as demais áreas curriculares. 
Por fim, destaca-se que o material analisado traz significativas contribuições para o ensino da matemática nos anos iniciais do Ensino Fundamental, porém ressalta-se a postura do professor em querer e saber fazer uma prática pedagógica onde a alfabetização matemática seja de fato prioridade para o processo ensino-aprendizagem.

\section{REFERÊNCIAS}

[1] Brasil. Ministério da Educação. Secretaria de Educação Básica. Diretoria de Currículos e Educação Integral Dicei. Coordenação Geral do Ensino Fundamental - COEF. Elementos conceituais e metodológicos para definição dos direitos de aprendizagem e desenvolvimento do ciclo básico de alfabetização $\left(1^{\circ}, 2^{\circ}\right.$ e $3^{\circ}$ anos $)$ do ensino fundamental. Brasília, DF: MEC, 2012.

[2] Brasil, Secretaria de Educação Básica. Diretoria de Apoio à Gestão Educacional. Pacto Nacional pela Alfabetização na Idade Certa: Apresentação. Ministério da Educação, Secretaria de Educação Básica, Diretoria de Apoio à Gestão Educacional. Brasília: MEC, SEB, 2014.

[3] Brasil, Secretaria de Educação Básica. Diretoria de Apoio à Gestão Educacional. Pacto Nacional pela Alfabetização na Idade Certa: Organização do trabalho Pedagógico. Brasília: MEC, SEB, 2014b.

[4] Brasil, Secretaria de Educação Fundamental. Parâmetros Curriculares Nacionais: Matemática. Brasília: MEC/SEF, 1997.

[5] Guerios, E.C., Agranionih, N.T., Zimer, T.T.B. AO Chegar À Escola.... In: Brasil, Secretaria de Educação Básica. Diretoria de Apoio à Gestão Educacional. Pacto Nacional pela Alfabetização na Idade Certa: Operações na resolução de problemas. Brasília: MEC, SEB, 2014.

[6] Fonseca, M. C. F. R. Prefácio. In: Nacarato, A. M.; Lopes, C. E. (Org.). Indagações, reflexões e práticas em leituras e escritas na educação matemática. Campinas: Mercado de Letras, 2013. p. 7-9.

[7] Nacarato, A.; Passos, C. e Grando, R. Organização do Trabalho Pedagógicopara A Alfabetização Matemática. In: Brasil, Secretaria de Educação Básica. Diretoria de Apoio à Gestão Educacional. Pacto Nacional pela Alfabetização na Idade Certa: Organização do trabalho Pedagógico. Brasília: Mec, Seb, 2014.

[8] Ortega, E.; Parisotto, A. Alfabetização Matemática na Perspectiva do Letramento no Pacto Nacional pela Alfabetização na Idade Certa. In: Educação em Revista. Marília. Disponível em: <http://revistas.marilia.unesp.br/index.php/educacaoemrevista/article/view/5845>. Acesso em: 23 mar. 2016.

[9] Soares, Magda. Letramento: um tema em três gêneros. 2. ed. Belo Horizonte: Autêntica, 2000.

[10] Spinillo, A.G. O sentido de número e sua importância na educação matemática. In: Brito, M.R.F. (Org.) Solução de problemas e a matemática escolar. Campinas: Editora Alínea, 2005.

[11] Vece, J.P., Mocrosky, L.F., Paulo, R.M. Diferentes enfoques no ensino de números. In: BRASIL, Secretaria de Educação Básica. Diretoria de Apoio à Gestão Educacional. Pacto Nacional pela Alfabetização na Idade Certa: Quantificação, registros e agrupamentos. Ministério da Educação, Secretaria de Educação Básica, Diretoria de Apoio à Gestão Educacional. Brasília: MEC, SEB, 2014. 


\section{Capítulo 3}

Professoras dos anos iniciais do ensino fundamental e suas relações com o ensino de matemática

\section{Manoel dos Santos Costa \\ Joemilia Maria Pinheiro Almeida}

Resumo: Este artigo tem como objetivo analisar a relação das professoras dos anos iniciais do Ensino Fundamental de uma escola pública maranhense, com o ensino de Matemática. Trata-se de uma pesquisa de Natureza qualitativa, cujo instrumento para a coleta dos dados foi um questionário com questões abertas. 0 interesse por esta investigação teve origem na experiência profissional do autor principal com o ensino de Matemática nesse nível de ensino, e na necessidade de compreender como as professoras desenvolvem os conteúdos de Matemática com seus alunos. Os dados expressam que, na maioria das vezes, elas desenvolvem os conteúdos por meio de jogos. A pesquisa concluiu, ainda, que as professoras tinham pouca afinidade com essa área do conhecimento, mesmo tendo sido formadas em curso superior específico para lecionar nesse nível de ensino. A falta de conhecimentos não era apenas relativa aos conteúdos matemáticos, mas também aos conhecimentos didáticos e curriculares. Esse fato ratifica a necessidade de a formação continuada trabalhar com as diversas metodologias de ensino sugeridas por pesquisadores e documentos oficiais, para que os professores se sintam mais confiantes para utilizá-las em sua prática docente.

Palavras-chave: Ensino de Matemática; Ensino Fundamental; Formação Continuada. 


\section{REFLEXÕES INICIAIS}

Nos ambientes de ensino e de formação de professores, temos percebido as dificuldades apresentadas pelos professores dos anos iniciais do Ensino Fundamental em desenvolver os conteúdos matemáticos com seus alunos. Em vista disso, resolvemos promover algumas atividades de formação continuada com professoras de uma escola pública estadual maranhense, para discutirmos o ensino de Matemática nesse nível de ensino. E aproveitamos um desses momentos, para aplicarmos um questionário, no sentido de que pudéssemos averiguar como elas desenvolvem os conteúdos matemáticos com seus alunos, e para sabermos qual era sua relação com essa área do ensino.

Sabemos que grande parte dos professores, hoje exercendo o magistério, nos anos iniciais do Ensino Fundamental, recebeu uma formação muito precária para ensinar Matemática. Uma vez que os professores dos anos iniciais ${ }^{2}$ tiveram sua formação comprometida nesse aspecto, como vão perceber a importância de ensinar Matemática para seus alunos? Como vão realizar esse trabalho em suas salas de aula? Essas indagações constituem o "pano de fundo" das questões que pretendemos discutir neste trabalho.

0 presente artigo encontra-se organizado em três seções principais. Inicialmente, apresentamos os aportes teóricos que tratam da formação matemática dos professores dos anos iniciais, seguidos, na segunda seção, do cenário da pesquisa: o contexto e a metodologia utilizada. Na terceira seção intitulada "a relação das professoras dos anos iniciais com o ensino de Matemática", apresentamos os dados e a análise sobre como as professoras desenvolvem os conteúdos com seus alunos e suas relações com o ensino de Matemática. A partir dessa discussão, expomos na seção Considerações Finais alguns caminhos para a formação de professores para esse nível de ensino, discutindo, também, a importância e as contribuições das atividades de formação continuada para o desenvolvimento profissional dos professores.

\section{A FORMAÇÃO MATEMÁTICA DOS PROFESSORES DOS ANOS INICIAIS DO ENSINO FUNDAMENTAL}

A literatura de pesquisa atesta que, nos ambientes de ensino e de formação de professores, existe uma dificuldade grande por parte dos professores dos anos iniciais em desenvolver os conteúdos matemáticos. Alguns professores mal conhecem quais conteúdos deverão ser trabalhados com os alunos. Alguns pesquisadores (CURI, 2005; COSTA, 2008; PIRES, 2012), que discutem a formação do professor para ensinar Matemática apontam limitações nessa formação.

Curi (2005) considera que a formação dos professores, que ensinam Matemática nos anos iniciais, continua sendo muito precária: "o conhecimento 'de e sobre' matemática é pouco enfatizado, mesmo no que se refere aos conteúdos previstos para o Ensino Fundamental [...]" (p. 69).

Os próprios professores detectam uma deficiência em sua formação inicial para ensinar Matemática, a qual não é um fato isolado (COSTA, 2008). As disciplinas relativas à Matemática e seu ensino, que constam das matrizes curriculares dos cursos de Pedagogia, têm uma carga horária bastante reduzida. Em geral, os cursos apresentam uma carga horária entre 36 e 72 horas para o desenvolvimento da disciplina (CURI, 2005; MELLO, 2008; COSTA, 2008). Os autores consideram essa carga horária insuficiente, para a formação do professor, tendo em vista a importância da Matemática nesse nível de ensino.

Nessa mesma linha de pensamento, Nacarato (2000) também assegura que, de modo geral, os cursos que formam professores dos anos iniciais oferecem uma carga horária reduzida e, na sua execução, quando oferecem disciplinas como Metodologia do ensino de Matemática ou Fundamentos da Matemática, muitas vezes contratam professores que não possuem experiência nesse nível de ensino. Nesse caso, a formação dos professores ficará comprometida, pois deixam de ter "condições de se preparar melhor para conduzir as mudanças necessárias a uma prática pedagógica mais atualizada" (NACARATO, 2000, p. 13), por não terem tido a chance de estudar conteúdo específicos que deverão ser por eles ensinados.

Alvarado Prada (1997) alega que muitas instituições de ensino superior, que se dedicam à formação de professores, caracterizam-se pela "contradição entre o que pretendem ensinar ou ensinam na teoria, e o que transmitem na prática" (p. 90). 
Nesse sentido, Nacarato e Paiva (2006) afirmam que a formação matemática dos professores dos anos iniciais será deficiente, se não for dada a oportunidade de construir um conhecimento aprofundado das diversas áreas da Matemática e de percorrer um leque variado de experiências matemáticas, incluindo a realização de trabalhos investigativos, resolução de problemas, modelagem matemática, e outros. Além disso, as autoras afirmam que as bibliografias utilizadas nesses cursos são generalistas e não incluem textos com pesquisas atuais de educadores matemáticos sobre o ensino e a aprendizagem de Matemática. Nessa mesma linha de pensamento, Pires (2012) assegura que "apropriar-se de resultados de pesquisas é fundamental para os profissionais que se dedicam a ensinar, em qualquer nível ou modalidade da escolaridade" (p.17).

Concordando com esses autores é que defendemos a ideia de que, nos debates de formação continuada, os professores formadores devem utilizar textos científicos recentes com o intuito de contribuir com o desenvolvimento e a atualização dos professores que estão em exercício. Além disso, cumpre que essa formação seja explicitada em múltiplas etapas, isto é, deve ir além de discutir metodologias da área (o que geralmente é feito), proporcionando também, o desenvolvimento de projetos, a troca de experiências, leituras, reflexões, etc.

Esse tipo de formação estimula o professor a se envolver mais com sua própria formação, além de incentivar e potencializar os estudos que ele realiza por meio da procura por informações e, principalmente, ajudando-o a se tornar investigador permanente de sua própria prática como docente (PIRES, 2012).

Nesse sentido, é necessário repensar os cursos de formação de professores dos anos iniciais, no que se refere à formação para ensinar Matemática. As especificidades próprias do ensino e da aprendizagem de Matemática pelas crianças e as características dos professores nesse nível de ensino devem ser consideradas nos projetos de formação. 0 atendimento a essas especificidades demanda nova organização dos cursos e indica a necessidade de subsídios para essas mudanças (CURI, 2005).

\subsection{CENÁRIO DA PESQUISA: CONTEXTO E METODOLOGIA}

A pesquisa aqui apresentada foi realizada junto a seis professoras dos anos iniciais de uma escola pública estadual maranhense, durante algumas atividades de formação continuada, realizadas na própria escola. 0 objetivo foi averiguar como as professoras desenvolviam os conteúdos matemáticos com seus alunos e suas relações com o ensino de Matemática.

As professoras participantes da pesquisa têm formação para o ensino nos anos iniciais: Magistério de nível médio e Licenciatura em Pedagogia, com exceção de uma elas que tem licenciatura em História, e outra que, além da Pedagogia, tem o curso superior em Serviço Social. A experiência dessas professoras com o Magistério é bastante significativa, em torno de 20 anos de experiência na área, e a média de idade delas é de 43 anos.

Trata-se de uma pesquisa de natureza qualitativa, pois aconteceu em um ambiente natural como fonte direta dos dados, e o pesquisador foi o seu principal instrumento, pois sua preocupação era discutir o ensino de Matemática dos anos iniciais com as professoras (GOLDENBERG, 2007).

O instrumento utilizado foi um questionário, considerado um instrumento tradicional de coleta de dados e consiste numa fonte de informações que ajudam na caracterização e descrição dos sujeitos de pesquisa (FIORENTINI; LORENZATO, 2009). Nesta pesquisa, o questionário possibilitou realizar um levantamento de dados pessoais e delinear o perfil das professoras participantes. As respostas obtidas permitiram a elaboração da análise dos dados, as quais serão apresentadas na próxima seção.

\section{A RELAÇÃO DAS PROFESSORAS DOS ANOS INICIAIS COM O ENSINO DA MATEMÁTICA}

Nesta seção apresentamos e discutimos os dados coletados por meio do questionário respondido pelas professoras $^{3}$ participantes da pesquisa. Iniciamos o questionário pedindo que completassem a seguinte frase: Decidi ser professora porque... 
Os motivos de as professoras terem escolhido essa profissão foram os mais diversos. A professora $\mathbf{P}_{2}$ escolheu a profissão porque achava que é uma profissão muito importante para a formação do ser humano e por gostar de ensinar. Já a escolha da professora $\mathbf{P}_{3}$ foi, segundo ela, por acreditar que poderia contribuir para a melhoria da formação das crianças e dos adolescentes.

Então, questionamos: Em qual classe/ano de escolaridade você gosta de lecionar?

Quatro professoras responderam que preferem lecionar na Educação Infantil, uma no primeiro ano, e outra respondeu segundo ou terceiro ano.

Continuamos perguntando se elas gostam de Matemática. Todas as professoras, responderam: não gostam de Matemática. Com exceção da professora, que também tem formação superior em Serviço Social, que respondeu gostar. Esse desgosto apontado pela maioria das professoras é destacado por Nacarato e Paiva (2006). Segundo as autoras, durante a formação inicial é explícito o desgosto manifestado pela maioria absoluta dos alunos que procuram os cursos de formação para o Magistério, em relação à Matemática. E ainda acrescentam: devido a esse desgosto, e também pela suposta incapacidade para a Matemática, quando está em sala de aula, esse professor tende a transmitir isso para os alunos, que passam, igualmente, a não gostar da disciplina.

Acreditamos que, devido às dificuldades encontradas na Matemática, as professoras a consideraram como sendo de difícil compreensão (causa) e, por isso, passam a não gostar (consequência ou efeito). Apenas uma delas, a que tem formação em Serviço Social, comentou que considera a Matemática como sendo de fácil compreensão.

Prosseguimos com nossos questionamentos e perguntamos: Como foi seu desempenho em Matemática, durante sua formação na Educação Básica (Ensinos Fundamental e Médio)? As respostas para esse item foram bem diversificadas. Três responderam que foi bom; duas, que foi regular, principalmente, no Ensino Médio; e apenas uma, respondeu que foi ótimo.

Questionamos, também, se haviam participado de alguma capacitação ou formação continuada nos últimos três anos. Quase todas responderam que sim; apenas uma respondeu que não havia participado de nenhuma formação nos últimos três anos. As formações que elas citaram, quanto à participação, foram sobre a importância da música na escola, em 2013; incentivo a leitura, em 2013; interdisciplinaridade, em 2014, e sobre as diretrizes curriculares, em 2014. Em 2015, a única formação continuada de que elas participaram foi o que realizamos na escola, em outubro, sobre o ensino de Matemática nos anos iniciais do Ensino Fundamental.

Podemos observar, por essas respostas, que nenhuma professora havia feito curso de formação continuada voltada para o ensino de Matemática, nos últimos três anos. Isso nos leva a crer que tanto as escolas quanto as secretarias de ensino têm demonstrado pouco interesse por essa formação. Uma única professora citou ter feito, no ano de 2010, quase 6 anos, o curso "Gestar Matemática", oferecido pela secretaria municipal de educação em que leciona.

Assim sendo, defendemos como necessária e urgente uma nova concepção para a formação continuada de professores, principalmente para aqueles que ensinam nos anos iniciais; uma formação que englobe, também, áreas específicas do conhecimento, como a Matemática, uma vez que as professoras a tiveram de forma insuficiente em sua formação inicial, conforme aponta Curi (2005).

Com relação ao ensino de Matemática, perguntamos: Como você costuma desenvolver os conteúdos com seus alunos? A professora $\mathbf{P}_{4}$ respondeu que utiliza materiais alternativos, tais como cartazes, material de sucata, música, jogos, brincadeiras, material dourado e o calendário do mês. Outras professoras responderam algo parecido: jogos, material dourado, calendário, brincadeiras, gráficos e problemas do dia a dia.

Algo que nos chamou a atenção, nas respostas dadas pelas professoras, foi o fato de todas terem respondido que desenvolvem os conteúdos matemáticos por meio de jogos. Isso nos levou a fazer o seguinte questionamento durante nossas discussões:

PE:- Que tipo de jogos vocês utilizam com seus alunos?

As professoras responderam:

$\mathrm{P}_{3}$ : - Faço uso do dominó, quebra-cabeça, jogos de encaixe e bingo.

$\mathrm{P}_{4}$ : - Faço uso do jogo da memória, do bingo de números e quebra cabeças. 
$\mathrm{P}_{6}$ : - Utilizo o jogo do boliche, para trabalhar as quatro operações básicas; fichas numéricas, para trabalhar as noções de sequência; dominó para cálculo mental envolvendo as quatro operações, e jogos envolvendo o material dourado.

Essa afinidade das professoras em desenvolver os conteúdos através de jogos também foi percebida nas respostas dadas, quando questionamos o que elas esperavam daquele momento da formação.

As professoras apresentaram respostas bem similares. A professora $\mathbf{P}_{6}$ respondeu: "espero que me auxilie a produzir jogos que facilitem o meu trabalho para proporcionar uma aprendizagem mais significativa e dinâmica com os alunos". A professora $\mathbf{P}_{4}$ respondeu: "espero que seja proveitoso, que possa me ajudar a desenvolver as aulas de Matemática por meio de jogos, que nos auxilie em mais opções de jogos que possam estimular o interesse dos alunos em trabalhar em grupos, que possam estimular a criatividade, 0 raciocínio lógico a socialização e à atenção. E que possa, também, haver trocas de experiências entre as colegas".

Além disso, elas comentaram que gostariam que as atividades de formação continuada discutissem sobre "novas estratégias educacionais" para melhorar e incentivar os alunos nas aulas de Matemática $\left(\mathbf{P}_{\mathbf{1}} ; \mathbf{P}_{2}\right)$.

Foi possível perceber, pelas respostas dadas pelas professoras, que elas se interessaram por novas formas de desenvolver os conteúdos com seus alunos, ou seja, elas estavam em busca de "novas" metodologias de ensino e aprendizagem. Talvez, esse interesse seja, entre outros motivos, por elas perceberem suas dificuldades com o ensino de Matemática.

Nesse sentido, alguns pesquisadores (CURI, 2005; COSTA 2008) e os Parâmetros Curriculares Nacionais PCN (BRASIL, 1997) já vêm sugerindo que os professores dos anos iniciais, devido às deficiências na formação inicial, busquem formação que discutem essas novas metodologias de ensino.

Também, notamos que, apesar de as professoras demonstrarem interesse por outras maneiras de se abordar a Matemática em sala de aula, geralmente elas recorrem ao uso de jogos. Por isso, acreditamos que algumas delas responderam que gostariam de ter mais discussões nas formações que abordassem o ensino de Matemática por meio de jogos.

Isso sugere que, apesar de as professoras já terem tido encontros de formação continuada recente, para discussões sobre as Diretrizes Curriculares, possivelmente não tenham sido debatidas, com elas, diretrizes específicas para o ensino de Matemática dos anos iniciais, tais como "o que" e "o como" desenvolver os conteúdos nesse nível de ensino com os alunos.

Houve quem demonstrasse esse mesmo interesse pela formação de outra maneira: a professora $\mathbf{P}_{6}$ respondeu que esperava que a formação ampliasse suas habilidades com relação ao tratamento didático dos conteúdos matemáticos. Ficamos com uma dúvida, por isso, no final da formação, a chamamos e questionamos:

PE: - O que você quis dizer com ampliar suas habilidades em relação ao tratamento didático?

A professora respondeu:

$\mathrm{P}_{6}$ : - Aprender novas maneiras, novas estratégias de abordar os conteúdos matemáticos de modo que possa despertar o interesse dos alunos.

Assim, o interesse dessa professora é o mesmo demonstrado pelas professoras $\mathrm{P}_{1}$ e $\mathrm{P}_{2}$, a busca por novas estratégias de ensino.

Com o intuito de saber qual a relação das professoras com o ensino da Matemática, pedimos que escrevessem um pequeno relato dessa relação. A seguir, apresentamos, na íntegra, alguns desses relatos.

A professora $\mathrm{P}_{3}$ relatou: "Gosto de trabalhar de forma expositiva, questionadora e trabalhos práticos com material concreto, pois minha turma apresenta um déficit muito grande de aprendizagem e tem dificuldade de concentração"

Outra professora, a $\mathrm{P}_{5}$ relatou: "Gosto da disciplina, mas, talvez pelo fato de não ter tido uma boa formação, às vezes encontro dificuldade; mas quando preciso de ajuda, procuro orientação de algum colega".

A professora $\mathrm{P}_{6}$ relatou: “A Matemática é considerada um 'bicho papão', mas eu, particularmente, desmistifiquei essa concepção, através das discussões realizadas nas formações continuadas em que participei e, descobri o quanto é fácil e prático dinamizar o estudo e a aprendizagem desta Ciência”.

Pelos relatos escritos pelas professoras, consideramos que, apesar de terem uma vasta experiência com o ensino dos anos iniciais, expressam dificuldade em descrever sua relação com o ensino de Matemática. 
Talvez isso tenha acontecido devido à falta de conhecimento do "quê" e de "como" devem ser abordados os conteúdos matemáticos com os alunos. Essa falta de conhecimento, provavelmente, deve-se ao fato de elas terem tido uma formação insatisfatória (mesmo aquelas que participam de atividades de formação continuada), isto é, por não terem tido a oportunidade de construir "novos" conhecimentos nas diversas áreas da Educação Matemática, conforme apontam Nacarato e Paiva (2006). Portanto, percebemos a necessidade de mudanças urgentes no desenvolvimento das atividades de formação continuada de professores, de modo que essas especificidades possam ser discutidas, uma vez que, conforme apontam as pesquisas já citadas os professores tiveram sua formação inicial comprometida, devido à carga horária oferecida para a discussão dessas temáticas.

\section{CONSIDERAÇÕES FINAIS}

O presente trabalho surgiu a partir das inquietações do autor principal enquanto professor da Educação Básica - Ensinos Fundamental e Médio, da rede estadual de ensino do Maranhão, aliado à sua prática como formador de professores e pesquisador dos anos iniciais. Como professor, tem percebido uma constante preocupação das colegas, que trabalham nos anos iniciais com o ensino de Matemática; enquanto formador, tem compreendido a busca por parte dos professores desse nível de ensino, por práticas metodológicas que os auxiliem no desenvolvimento dos conteúdos matemáticos.

E, enquanto pesquisador, tem ciência de estudos que comprovam a falta de conhecimentos de "como ensinar" os conteúdos matemáticos aos alunos.

Se os cursos de habilitação para o Magistério de nível Médio pouco contribuíram para a formação matemática dos professores dos anos iniciais, também são assim os atuais cursos de Pedagogia, que, na maioria das instituições de ensino superior, mostram-se deficitários. Percebemos isso também em Curi (2005) e Costa (2008), quando estes autores fazem uma crítica sobre a matriz curricular dos cursos de Pedagogia, em que raramente são encontradas disciplinas voltadas à formação de professores para ensinar Matemática.

Acreditamos que, talvez por isso, a maioria das professoras tenham declarado que não gostam da Matemática, por apresentarem marcas negativas que elas trazem consigo em relação a essa disciplina. Isso, segundo Nacarato e Paiva (2006), talvez seja o que mais implica, muitas vezes, no bloqueio para aprender e, também, para ensinar os conteúdos matemáticos.

Possivelmente, essas "marcas negativas" é que têm ensejado as professoras a demonstrarem uma expressiva preocupação com relação ao ensino, nessa área do conhecimento. Daí surgiu nossa inquietação e o interesse em averiguar como elas desenvolvem os conteúdos matemáticos com seus alunos, e em sabermos qual sua relação com essa área do ensino. Além disso, procuramos identificar-lhes os seus interesses e as lacunas com relação à sua prática com o ensino de Matemática, para que pudéssemos organizar nossas próximas formações, as quais acontecerão na própria escola. Nossa preocupação vai ao encontro do que propõem Nacarato e Paiva (2006): que devemos dar oportunidade às professoras dos anos iniciais de construírem novos conhecimentos e novos métodos de ensino para serem desenvolvidos nos diversos ramos da Matemática, realizando debates e trocas de experiências.

\section{REFERÊNCIAS}

[1] Alvarado Prada, L. E. Formação de Docentes em Serviço. In: Formação participativa de docentes em serviço. Taubaté, SP: Cabral Editora Universitária, 1997. p. 87-103.

[2] Brasil. Ministério da Educação e do Desporto. Secretaria de Educação Fundamental. Parâmetros Curriculares Nacionais: Matemática. 3. ed.- Brasília: A Secretaria, 1997.

[3] Costa, M. S. Discutindo o ensino de geometria com professores polivalentes. 2008, 145 f. Dissertação (Mestrado em Ensino de Ciências e Matemática) - Universidade Cruzeiro do Sul, São Pulo, 2008.

[4] Curi, E. A matemática e os professores dos anos iniciais. São Paulo: Musa Editora, 2005.

[5] Fiorentini, D.; Lorenzato, S. Investigações em educação matemática: percursos teóricos e metodológicos. Campinas, SP: Autores Associados, 2009.

[6] Goldenberg, M. A arte de pesquisar: como fazer pesquisa qualitativa em ciências sociais. Rio de Janeiro: Record, 2007. 
[7] Mello, B. C. K. Formação matemática de professores polivalentes: um estudo de caso. 2008. 276 f. Dissertação (Mestrado em Ensino de Ciências e Matemática) - Universidade Cruzeiro do Sul, São Paulo, 2008.

[8] Nacarato, A. M. Educação continuada sob a perspectiva da pesquisa-ação: Currículo em ação de um grupo de professoras ao aprender ensinando Geometria. 2000. 330f. Tese (Doutorado em Educação) - Faculdade de Educação, UNICAMP, Campinas.

[9] ___ _ Paiva, M. A. V. A formação do professor que ensina matemática: perspectivas e pesquisas a partir das investigações realizadas pelos pesquisadores do GT7 da SBEM. In: Nacarato, Adair Mendes; Paiva, Maria Auxiliadora Vilela (Orgs.). A Formação do professor que ensina Matemática. Belo Horizonte: Autêntica editora, 2006. p. 7-26.

[10] Pires, C. M. C. Educação Matemática: conversas com professores dos anos iniciais. 1. ed. São Paulo: Zé-Zapt, 2012. 


\section{Capítulo 4}

Formação de professores que lecionam matemática para os anos iniciais: Um estudo acerca de conhecimentos das estruturas aditivas e do seu ensino

\section{Elys Vânny Fernanda Rodrigues de Oliveira \\ Angélica da Fontoura Garcia Silva}

Resumo: Esta comunicação tem o propósito de analisar os Conhecimentos relacionados ao ato de ensinar e do Campo Conceitual aditivo de um grupo de professoras que participaram de um processo de formação continuada acerca das estruturas aditivas desenvolvido na própria escola em que atuam. Trata-se de uma pesquisa qualitativa, desenvolvida com 4 docentes que lecionam Matemática para os anos iniciais de uma escola particular de Fortaleza. A análise dos dados fundamentou-se nos estudos de Ball, Thames e Phelps acerca dos conhecimentos necessários para o ensino e na Teoria dos Campos Conceitual de Vergnaud. As respostas do grupo indicaram que nesse primeiro momento as professoras ainda apresentavam um conhecimento do conteúdo e do ensino limitado, - por exemplo, demonstraram preocupação em apresentar tarefas de "arme e efetue" quando a solicitação era a de elaborar situações, houve predominância de criação de problemas prototípicos envolvendo a ideia de composição.

Palavras-chave: Formação de professores; Campos Conceituais Aditivos; Anos Iniciais. 


\section{INTRODUÇÃO}

O cenário do estudo é um processo de formação continuada de professores que lecionam para os terceiros anos iniciais do Ensino Fundamental. Esses educadores, pertencentes a uma escola da rede particular de Fortaleza, participaram de encontros de formação, em sua própria escola, nos quais discutiram a temática "Possibilidades de resolução de problemas de estruturas aditivas sob o olhar de Vergnaud".4 Tal processo contou com 8 encontros presenciais, com 2 horas cada, totalizando 16 horas. Entretanto, para esta comunicação analisaremos as situações elaboradas pelas professoras no início da formação de acordo com o Conhecimento do Conteúdo na perspectiva de Ball, Thames e Phelps (2008) e do Ensino do Campo Conceitual Aditivo e as análises desenvolvidas por elas durante uma das sessões de formação.

\section{RELEVÂNCIA DO ESTUDO}

Para realizar esta investigação nos apoiamos em resultados de pesquisas que apontam haver estreita relação entre as situações elaboradas por professores e o desempenho dos alunos. Magina (2011); Miranda (2014) e Etchverria (2014), por exemplo, destacam a relação entre as situações do Campo aditivo formuladas por professores e o rendimento dos estudantes. A mesma relação foi observada por Magina, Merlini e Santos (2013) e Pinheiro (2013) para estruturas multiplicativas e frações. Quanto às estruturas aditivas, Magina (2011), por exemplo, realizou um estudo com 103 professores que lecionavam para os anos iniciais do Ensino Fundamental e comparou com resultados de desempenho dos 5으 anos desse mesmo segmento de ensino (alunos de 9 e 10 anos) em macroavaliações (SAEB). Ao analisar os resultados à luz da Teoria dos Campos Conceituais a autora concluiu que:

Comparados os resultados desses problemas com os resultados obtidos pelos estudantes da 4a série do Ensino Fundamental, nos mais recentes instrumentos diagnósticos oficiais (BRASIL, 2006; 2008), pode-se ver que existe uma estreita relação entre o desempenho das crianças nesses diagnósticos e o tipo de problemas que os professores do estudo elaboraram. (MAGINA, 2011, p.71)

Resultados semelhantes a esse foram encontrados em 2014 por Etchverria no estudo denominado por ela como Diagnóstico, ao investigar a relação entre as situações presentes no livro didático e as formuladas pelos professores participantes que lecionavam em uma escola de Sergipe e o conhecimento explicitado por seus alunos. A autora analisou o livro didático, aplicou aos 248 alunos um questionário contendo 10 situações envolvendo as estruturas aditivas e solicitou a seus professores a elaboração de seis problemas de adição e/ou subtração. Segundo essa pesquisadora seus resultados: "confirmam uma relação entre os problemas aditivos elaborados pelas professoras, os problemas de adição e subtração do livro adotado pela escola e o desempenho dos estudantes nesses tipos de problemas". (ETCHVERRIA, 2014, p.233). Dessa forma, consideramos ser relevante também que ao iniciar o processo formativo solicitássemos as professoras participantes a elaboração de questões envolvendo as estruturas aditivas. Pretendíamos, com isso, obter as primeiras informações sobre as concepções relativas ao Campo Conceitual Aditivo explicitados pelo grupo de professores.

\section{FUNDAMENTAÇÃO TEÓRICA}

Para alicerçar este estudo, nos apoiaremos na Teoria dos Campos Conceituais, sobretudo do Campo Conceitual Aditivo proposta por Vergnaud $(1983,2009,2010)$ e acerca

dos conhecimentos necessários para o ensino descritos por Ball, Thames e Phelps (2008). No tocante a Teoria dos Campos Conceituais (TCC) Gérard Vergnaud é um dos primeiros psicólogos a se interessar pela questão dos conteúdos de ensino no âmbito de uma psicologia cognitiva. Esta teoria tem base piagetiana e alguns pontos sedimentados em Vygotsky. No que diz respeito à teoria socio-histórico-cultural de Vygotsky, Vergnaud (2010) atribui valor às interações sociais, à linguagem e às suas representações. Do escopo de Piaget os pontos utilizados por Vergnaud são como se organizam: as operações lógicas, as estruturas gerais do pensamento e o conceito de esquema, dentre outros. Para Vergnaud, Jean Piaget criou uma importante obra que tinha como objetivos centrais investigar como a criança se desenvolvia e compreender os conceitos que permeavam o seu contexto. Porém, Vergnaud amplia este olhar quando se interessa pela aprendizagem dos conceitos que são ensinados no âmbito escolar.

${ }^{4}$ (Essa formação resultou uma dissertação de mestrado intitulada: Formação Continuada de Professores e sua Reflexão: Estudo de situações do campo conceitual aditivo.) 
A definição de Campo Conceitual sob a ótica de Vergnaud "É um conjunto de problemas e situações para o tratamento necessário de conceitos, procedimentos e representações de diferentes tipos, mas que têm interconexões muito próximas." (VERGNAUD, 1983, p. 127). 0 controle dos aspectos supracitados se desenvolve em um dado tempo e por meio da experiência, aprendizagem e maturação. Vergnaud desenvolve uma teoria que se propõe fornecer uma estrutura à aprendizagem e que seu principal objetivo é compreender as rupturas e conexões entre os conhecimentos. E sua defesa teórica se sedimenta em propor uma tríade que, ao inter-relacionar os seus três componentes: Situação, Invariantes e as Representações, que podemos representar assim (S, I e R), compõem a Teoria do Campo Conceitual (TCC).

Como nosso foco será a análise das situações destacaremos as indicações do autor para esse componente. Vergnaud (2009) defende que a apropriação do conhecimento acontece por meio da vivência de situações diversas e que os conceitos podem variar de acordo com o desenvolvimento individual do sujeito. A situação (S) é definida como um conjunto de situações que auxiliam na significação do conceito, ou seja, aquilo que pode dar sentido e influir na compreensão dos conceitos quando são internalizados. Dessa feita, ganham significado para o aprendiz, de acordo com as experiências diversas e conhecimentos prévios de cada ser, até aquele momento, como nos confirma Vergnaud, (...) "os processos cognitivos e as respostas do sujeito são função das situações com que ele se confronta”. (VERGNAUD, 1996, p.12). Nossa escolha pelas estruturas aditivas se deve ao fato de que todas as professoras desenvolviam seu trabalho sobre essa temática e o consideravam satisfatório,entretanto Vergnaud (2010) considera que o domínio desse Campo Conceitual não é tão imediato. Para o autor a teoria do Campo Conceitual do Campo Aditivo constitui o conjunto das situações cujo tratamento utiliza uma ou várias adições ou subtrações ampliadas do conjunto dos conceitos e teoremas que traçam uma análise dessas situações como tarefas matemáticas.

Vergnaud $(1993,2009)$ identifica seis categorias, também chamadas de relações de base. Nas estruturas aditivas propostas por Vergnaud (2009) encontramos 6 relações de base ou categoria que iremos exemplificar no Quadro 1, a seguir:

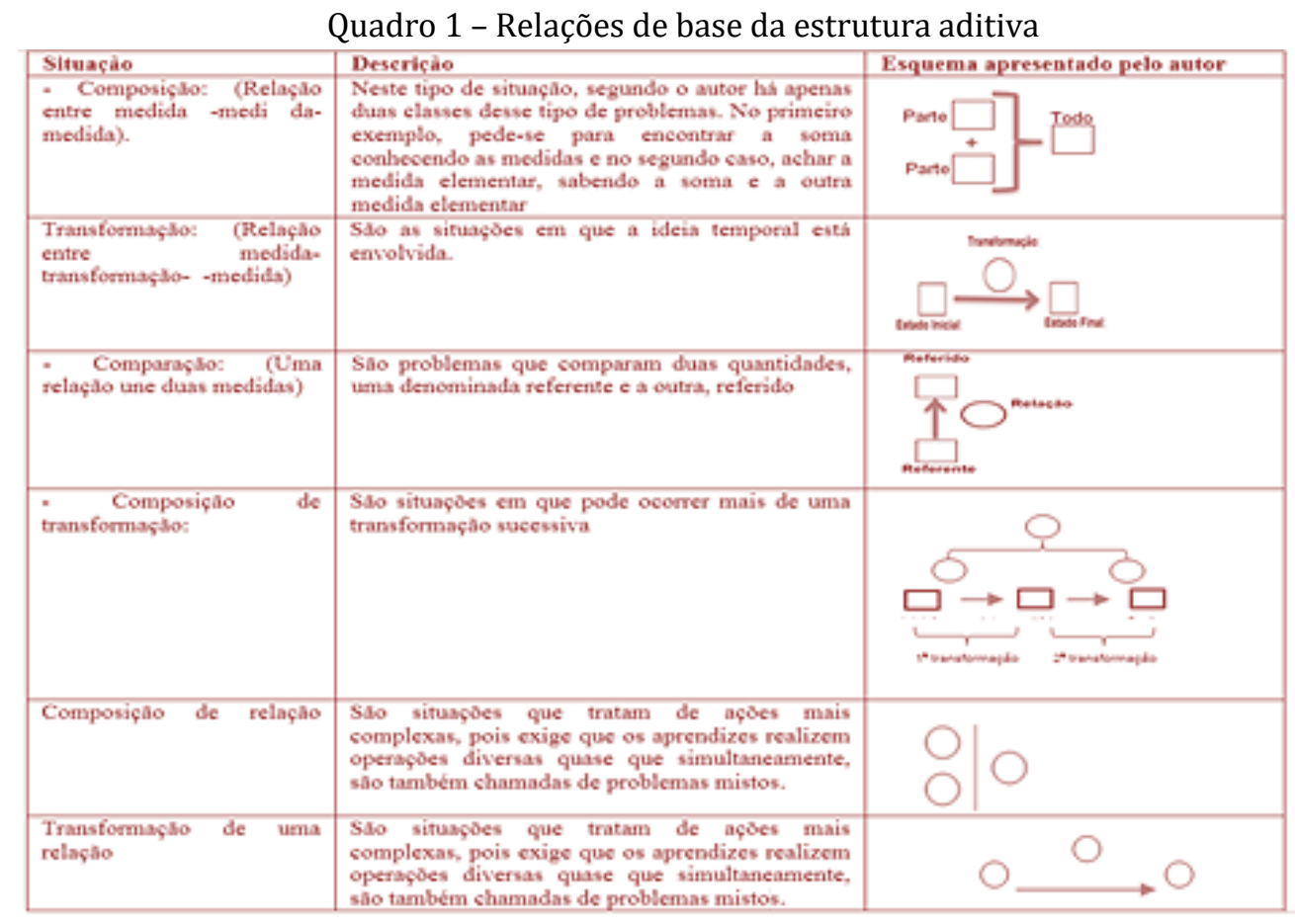


Ao observarmos a diversidade de ideias e processos mentais que são propostos por situações variadas no quadro acima, consideramos que o papel do professor é fundamental, sobre isso concordamos com Vergnaud (2004) que para a realização do ensino:

(...) que seu primeiro ato [do professor] de mediação é a escolha de situações, (...) 0 professor toma decisões o tempo todo, mas a escolha de situações é, provavelmente, a decisão mais importante na lógica dos campos conceituais, porque ela supõe tanto

uma reflexão epistemológica e uma adaptação aos alunos e as questões que venham a surgir (...). (VERGNAUD, 2004, p. 37-38)

Para que essas escolhas e decisões sejam mais conscientes, necessitamos indagar algumas questões: Quais os conhecimentos necessários que compõem a sua ação docente? A partir do que essas questões suscitam, iremos trazer à tona estudos Ball, Thames e Phelps categorizam os conhecimentos necessários para o ensino em: conhecimento do conteúdo (comum/horizontal/especializado); conhecimento pedagógico do conteúdo (conhecimento do conteúdo e dos estudantes; conhecimento do conteúdo e do ensino e conhecimento curricular). Considerando esse marco teórico, para esse estudo investigaremos os conhecimentos acerca das estruturas aditivas e sua relação com o ato de ensinar, ou seja, procuraremos analisar os conhecimentos do conteúdo e do ensino dos professores participantes. Consideramos assim como Ball, Thames e Phelps (2008) a importância que o professor crie e escolha exemplos que possibilitem aos seus alunos a compreensão desse campo conceitual.

\section{PROCEDIMENTOS METODOLÓGICOS}

Nossa pesquisa se caracteriza por aspectos qualitativos, pois analisamos o processo e não meramente os resultados obtidos. Coletamos as informações a partir de um questionário inicial apresentado as quatro professoras participantes na primeira sessão de formação. Pretendíamos com a análise dos dados elaborarmos 0 primeiro plano para o processo de formação continuada na própria escola. A partir da análise do questionário e das situações apresentadas pelas professoras foi organizado o processo de formação.

\section{ANALISE DOS DADOS}

Nesse questionário solicitamos às professoras que formulassem 8 questões que envolvessem as operações de adições e subtrações. Elas construíram as questões de forma individual sem a nossa mediação, por fim recolhemos o material para análises e comparações entre as questões produzidas ao fim da formação e aquelas que foram formuladas na fase inicial. As professoras eram responsáveis pelos $3^{\circ}$ anos do Ensino Fundamental naquela escola e as denominamos como P1, P2, P3 e P4, para preservarmos suas identidades. Analisando seu perfil, podemos afirmar quem a maioria tinha entre 45 e 49 anos, com experiência de ensino variada: P1 estava em início de carreira, P4 lecionava há mais de 5 anos, P3 entre 15 e 19 anos e P2 estava com mais tempo uma vez que lecionava há mais de 20 anos. É importante destacar que todas as professoras já haviam concluído a graduação e estavam frequentando cursos de pósgraduação. Todavia, mesmo considerando que todas estejam cursando especialização, nenhuma das professoras investigadas admitiu ter algum contato com estudos que discutem a Teoria dos Campos Conceituais. Quando questionadas como elas preparavam suas aulas todas indicaram utilizar livros. Segundo P1 e P2, por exemplo, elas trabalhavam "com base em livros que trazem novas formas de ensinar e outras pesquisas", P3 e P4, também afirmaram apoiar-se em livros "que trazem novas formas de ensinar". Nesse sentido, podemos observar que todas procuravam indicações metodológicas nos livros. Para classificar as tarefas, analisamos 6 categorias5: Tipos de Tarefas (Ta); Quantidade de Situações (Si); Compreensão explicitada (Co); Classificação segundo Vergnaud (Cl); e, finalmente, se for situação, se é uma relação ternária (Tern) ${ }^{6}$. Essas categorias foram organizadas em subcategorias conforme

\footnotetext{
5 Esta classificação foi inspirada no desenho metodológico apresentado no projeto Observatório da Educação - OBEDUC/EMULT que promove o desenvolvimento de estudos e pesquisas com escolas públicas dos estados da Bahia, Ceará e Pernambuco com a temática central das estruturas multiplicativas de Vergnaud, mas adaptamos para o desenho metodológico para campo conceitual aditivo. Os resultados dos estudos e pesquisas do Grupo OBEDUC /EMULT estão no prelo.
}

${ }^{6}$ Segundo Silva (2010) “Relação ternária: Uma relação ternária R (a, b, c) é uma relação entre os elementos a, b, c em que R tem uma relação ternária $\mathrm{R}$ sobre três universos $\mathrm{A}, \mathrm{B}$ e $C$ (não necessariamente diferentes) é definida por $\mathrm{R} \subseteq \mathrm{AX} \mathrm{B} X \mathrm{C}$, ou seja, $R$ é um subconjunto do produto cartesiano entre $A, B$ e $C^{\prime \prime}$. (SILVA, 2010, pp. 21 e 22). 
apresentado no Quadro 2.

Quadro 2 - Significado dos códigos e das siglas

\begin{tabular}{|c|c|c|}
\hline Ta: Tarefa & B: beanco & Op: operaçio \\
\hline Si: Situaçıo & Av: suséncis & Ua: ùntea \\
\hline Co: Comprerasào & \multicolumn{2}{|c|}{ 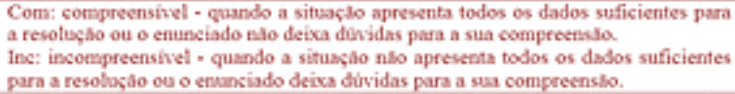 } \\
\hline $\mathrm{Cl}$ Classe & $\begin{array}{l}\text { Au: auscincis Comp } \\
\text { Compa: comparacto }\end{array}$ & $\begin{array}{l}\text { composicto Transf transformaça positina os nezativa } \\
\text { Mista: combinaçao de problemas com mais de uma classe. }\end{array}$ \\
\hline Tern: Teruiria & Ter: temária & N Ter: nso termaria \\
\hline
\end{tabular}

A análise final das tarefas (situações ou operações) criadas pelas professoras foi realizada por meio da tabulação dos dados organizados nos quadros 3, 4, 5 e 6.0 quadro a seguir contém as tarefas produzidas p ela professora P1.

Quadro 3 - Tarefas elaboradas pela professora P1

\begin{tabular}{|c|c|c|c|c|c|c|}
\hline \multicolumn{7}{|l|}{ Questilo elaborada P1 } \\
\hline \multirow{5}{*}{$\begin{array}{l}\text { Q1) Ricardo e Joìo colecionam figurinhas. Certo dia } \\
\text { resolveram juntá-las, Ricardo tinha } 12 \text { figurinhas e Jodo } \\
\text { 16. Quantas figurinhas tinham juntos? }\end{array}$} & Tarefa & B & $\mathrm{Si}$ & 8n & & \\
\hline & Situação & Au & Wo & $\mathrm{v}$ & & \\
\hline & Compreensăo: & Ins. & Com & & & \\
\hline & Classe: & Au & Comp. & Transf & Compa & Mista \\
\hline & Rel. Ternária: & Ter & N ter & & & \\
\hline \multirow{5}{*}{$\begin{array}{l}\text { Q2) Carol tinha } 14 \text { pirulitos que ganhou de sua avó. } \\
\text { Quando foi at casa de sua tia resolveu doar } 7 \text { pirulitos } \\
\text { para sua prima. Ao chegar em casa, Carol foi contar os } \\
\text { pirulitos, quantos restaram? }\end{array}$} & Tarefa: & B & $\mathrm{Si}$ & op & & \\
\hline & Situaçăo: & Au & In & $\mathrm{v}$ & & \\
\hline & Compreensāo: & Ine. & Com & & & \\
\hline & Classe: & Au & Comp & Transe & & Mista \\
\hline & Ternaria: & Ter & N ter & & & \\
\hline \multirow{5}{*}{$\begin{array}{l}\text { Q3) Joana, Carlos e Levi recebem mesadas de seus pais. } \\
\text { Joana recebe rS } 10,00 \text {, Carlos } \mathrm{rS} 15,00 \text { e Levi rS } 10,00 \text {. } \\
\text { Qual o total das mesadas de joana e Levi? Se os trés } \\
\text { amigos resolvessem juntar suas mesadas, quanto teriam } \\
\text { juntos? }\end{array}$} & Tarefa: & B & Si & Qp & & \\
\hline & Situação: & Au & Wo & $\mathrm{v}$ & & \\
\hline & Compre & Ine & Com & & & \\
\hline & Cla & An & Comn & Ixansf & & Mista \\
\hline & Rel ternária: & Ter & $N$ ter & & & \\
\hline \multirow{5}{*}{$\begin{array}{l}\text { Q4) Os alunos do colégio } 7 \text { de setembro tiveram aula de } \\
\text { matemática e a professora pediu que resolvessem a } \\
\text { seguinte adichto: } 56+37= \\
\text { Resolva no seu cademo e explique para a turma como } \\
\text { chegou ao resultado: }\end{array}$} & Tarefa: & B & Si & $\Omega p$ & & \\
\hline & Situação: & Au & Lo & $\mathrm{v}$ & & \\
\hline & Compre & Ins. & Com & & & \\
\hline & Classe: & $\mathrm{Au}$ & Comp. & Iranse & compa & Mista \\
\hline & Rel. Ternária: & Ter & N ter & & & \\
\hline \multirow{5}{*}{$\begin{array}{l}\text { Q5) Marcos tem } 40 \text { bolinhas de gude. No final de } \\
\text { semana foi brincar com seus amigos e perdeu } 20 \\
\text { bolinhas. Com quantas bolinhas ele ficou? }\end{array}$} & Tarefa: & B & Si & $\rho p$ & & \\
\hline & Situaçäo: & Au & Lo & $\mathrm{v}$ & & \\
\hline & Compreensăo: & Ing & Com & & & \\
\hline & Classe: & Au & Comp & Iransf & Compa & Mista \\
\hline & Rel. ternária: & Ter & Nter & & & \\
\hline \multirow{5}{*}{$\begin{array}{l}\text { Q6). Resolva a seguinte adiça no quadro de valores e } \\
\text { ustifique passo a passo como vocé conseguiu chegar ao } \\
\text { resultado. } \\
(136+125 \Rightarrow)\end{array}$} & Tarefa: & $\mathbf{B}$ & Si & $\rho_{P}$ & & \\
\hline & Situaçào: & Au & In & $\mathrm{v}$ & & \\
\hline & Compreen & Ine & Com & & & \\
\hline & Classe: & $\mathrm{Au}$ & Coma & Iraase & & Mista \\
\hline & Rel. ternária: & Ter & N ter & & & \\
\hline \multirow{5}{*}{$\begin{array}{l}\text { Q7) Arme e efetue: } \\
\text { a) } 28+15= \\
\text { b) } 38-26= \\
\text { c) } 143+12=\end{array}$} & Tarefa: & $\mathbf{B}$ & Si & $\Omega_{p}$ & & \\
\hline & Situação: & Au & Wo & $\mathrm{v}$ & & \\
\hline & Compreensăo: & Ioc & Com & & & \\
\hline & Classe: & Au & Coma. & Ixanaf & Somper & Mista \\
\hline & Rel. terná & Ter & N ter & & & \\
\hline \multirow{4}{*}{$\begin{array}{l}\text { Q8) Maria tem } 84 \text { canetinhas em sua coleç̃o. Certo dia } \\
\text { resolveu doar para suas trés amigas. Deu } 15 \text { cartinhas } \\
\text { para sua melhor amiga, } 3 \text { para sua vizinha e } 5 \text { para sua } \\
\text { prima. Com quantas canetinhas maria ficou? E quantas } \\
\text { ela deu para suas amigas? }\end{array}$} & Tarefa: & B & Si & $\Omega p$ & & \\
\hline & Situaçào: & Au & Sin & $\mathrm{v}$ & & \\
\hline & Compreensāo: & Ioc & Com & & & \\
\hline & Classe: & Au & Comp. & Iranse & Compa & Mista \\
\hline
\end{tabular}

Analisando os dados, é possível perceber que a professora P1 demonstrou preocupação em oferecer aos estudantes vivências de situações contextualizadas, mas também tarefas que avaliem somente os procedimentos de cálculo. P1 elaborou 8 tarefas, das quais 5 eram situações e 3 operações, todavia, das situações, duas não abordavam relação ternária. Ao realizar a análise das situações ternárias, observamos que todas elas eram prototípicas e 1 envolvia situação de composição, enquanto 2 de transformação. Cabe ressaltar que, duas das situações não eram ternárias, mas envolviam situações de composição e transformação mais simples, em que se buscava o todo na composição e o estado final na transformação. Para analisar as tarefas elaboradas pela professora P2, tabulamos e analisamos os resultados do quadro 4: 
Quadro 4 - Tarefas elaboradas pela professora P2

\begin{tabular}{|c|c|c|c|c|c|c|}
\hline \multirow{3}{*}{ 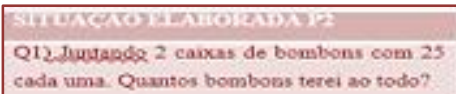 } & \multicolumn{6}{|c|}{ 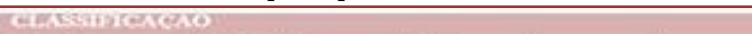 } \\
\hline & \multirow{2}{*}{ Tarefa: } & \multirow{2}{*}{$\begin{array}{l}B \\
x\end{array}$} & \multirow{2}{*}{$\begin{array}{l}\text { Si } \\
\text { Con }\end{array}$} & Op & & \\
\hline & & & & V & & \\
\hline & Compreensiot & TuE & $\operatorname{cotr}$ & & & \\
\hline & Classe: & An & Comp & Trans? & Compa & Masta \\
\hline & Rel-termaria: & Te: & Nter & & & \\
\hline Q22 Teubo 32 brinquedon Quantos & Tareta: & B & si & Os & & \\
\hline brinquedos faltam pera 40 ? & 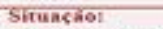 & तu & Ca & $\mathrm{v}$ & & \\
\hline & Compreensiot & The & Cow & & & \\
\hline & Classe: & Au & Comp & Trange? & Compa & Masta \\
\hline & Rel. Ternánat & Ter & Neter & & & \\
\hline Q3) Jollo comprou 2 ingressos de RS 24,00 & Tarefa: & B & si & Op & & \\
\hline para o cinema. Quarto ole pagou pelos 2 & Stcuarat: & Ku & Th & $\mathrm{v}$ & & \\
\hline ingreasos? & Compreensio: & Tne & $\operatorname{coth}$ & & & \\
\hline & Classe: & $\lambda=$ & Comp & Trans? & Coripa & Mana \\
\hline & Rel. termatia: & Tet & Nent & & & \\
\hline Q42 tion feirante vendeu 3 caixas de taranjas & Tarefat & B & si & Op & & \\
\hline com $15 \mathrm{~cm}$ cada uma Quantas laranjas & Situactol & तu & $C_{n}$ & $\mathrm{v}$ & & \\
\hline vendeu no total? Quantas faltariam para 50 & Compreensio: & The & $\operatorname{com}$ & & & \\
\hline Laranjas? & Classe: & तu & Comp & Transer & Conipa & Matia \\
\hline & Rel. ternbiria: & Tez & N ter & & & \\
\hline Q5) Ana deu 14 dos seun 36 lopis para & Tarefa: & B & si & op & & \\
\hline Cartos. Com quantos lípis Ana ficou? & Sicuasiso: & $A \times$ & Un & $\mathrm{v}$ & & \\
\hline & Compreensian & The & Com & & & \\
\hline & Classe: & Au & Comp & Trante & Compa & Minta \\
\hline & Fel. ternbriat & Te: & Neer & & & \\
\hline Q6) Tentho RS 27,00 para coenprat uma & Tarefa: & B & si & op & & \\
\hline blusa que custa RS 30,00. Quanto falta para & Situasso: & $x_{\mathbb{B}}$ & On & $\mathrm{v}$ & & \\
\hline complemserstar a quantia da blusa? & Compreensio: & Ine & $\operatorname{coth}$ & & & \\
\hline & Classe: & An & Comp & Trama? & Compa & Masta \\
\hline & Rol ternaria: & Te: & Xiter & & & \\
\hline Q7) No aniveraário de Paulo tinham 23 & Tarefa: & B & si & on & & \\
\hline crianças, 11 eram meninas. Quamos eram os & Struacao: & dM & Co & v & & \\
\hline mesimos? & Compreensai: & गब & $\operatorname{com}$ & & & \\
\hline & Classe: & dश & Sospue & JEseve & Sesoups & MISTA \\
\hline & Rel. termana! & Te & Noter & & & \\
\hline Q3) Merta comprou 13 pares de meias, 12 & Tarefa: & B & si & Op & & \\
\hline do calcas of cistos para sua loja. Quantas & Struaşa: & aर & Tha & $\nabla$ & & \\
\hline pocas ela cornptou ao todo? & Compreensio: & The & $\operatorname{com}$ & & & \\
\hline & Classe: & 20 & Csume & Tresing & Csouses & MIISTA \\
\hline
\end{tabular}

Explorando os dados apresentados pela professora 2 (P2), percebemos que houve variações nas questões formuladas. A P2 elaborou 8 tarefas que eram em sua totalidade situações contextualizadas. Ao realizar a análise das situações, observamos que as questões: Q1, Q3 e Q4 tinham a ideia do campo multiplicativo demarcado nas suas formulações, ou seja, havia uma relação fixa entre as duas variáveis. No caso da adição, se trabalha com a noção de que a soma das partes é igual ao todo, sendo que as partes são de uma mesma natureza, isto é, envolve somente uma variável. Acreditamos que isso tenha ocorrido, pois o momento em que solicitamos as questões formuladas pelas professoras, elas estavam realizando em sala de aula estudos sobre a operação multiplicação. Todavia, mesmo com a ideia do campo multiplicativo, nós a classificamos como composição prototípica, pois é a relação de base que enfatiza operações com partes iguais (adição de parcelas iguais). Quatro questões (Q2, Q6, Q7 e Q8) foram feitas sobre a relação de composição. Duas dessas (Q6 e Q8) foram formuladas de maneira prototípica em que sabemos as partes e queremos saber o todo e as outras de 1a extensão, em que sabemos o todo e uma das partes e procuramos descobrir a outra parte do todo. Tivemos, também, uma questão de transformação subtrativa prototípica, que se sabia o estado inicial e a transformação e buscava-se o estado final, após a transformação. Para analisar as tarefas elaboradas pela professora $\mathrm{P} 3$, tabulamos e analisamos os resultados do quadro 5 : 
Quadro 5 - Tarefas elaboradas pela professora P3

\begin{tabular}{|c|c|c|c|c|c|c|}
\hline \multirow{3}{*}{ 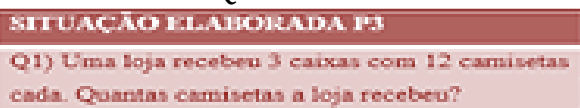 } & \multicolumn{6}{|c|}{ 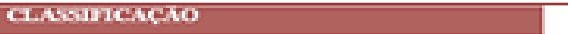 } \\
\hline & \multirow{2}{*}{ 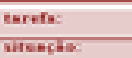 } & \multirow{2}{*}{$\frac{b}{a a}$} & \multirow{2}{*}{$\frac{\text { si }}{\text { sin }}$} & op & & \\
\hline & & & & $\mathrm{v}$ & & \\
\hline & $\operatorname{sempraseck}$ & $=0$ & Com & & & \\
\hline \multirow{7}{*}{$\begin{array}{l}\text { Q2) Na sala de cinema tem } 9 \text { cadeiras em } 10 \\
\text { fileiras. Quantas cadeiras tem no cinema? }\end{array}$} & Shask & ma & cenese & trank & eompara & mista \\
\hline & 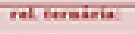 & Fer & nter & & & \\
\hline & earefe: & $b$ & ii & op & & \\
\hline & siterecta: & $m a$ & $\mathbf{w}$ & $\mathrm{v}$ & & \\
\hline & comprataske & $\operatorname{inc}$ & $\mathrm{com}$ & & & \\
\hline & Shave & $x=$ & $\cos \theta$ & trand & compa & mistz \\
\hline & Selt tarestis: & $E=$ & nEer & & & \\
\hline \multirow{5}{*}{$\begin{array}{l}\text { Q3) Marcelo e Régis colecionam figurinhas. } \\
\text { Marceto tem } 35 \text { e Regis tem } 40 \text {. Quantas } \\
\text { figurinhas os dois tèm juntos? }\end{array}$} & eareft: & $b$ & si & 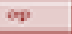 & & \\
\hline & sirestas & wi & $\omega$ & $r$ & & \\
\hline & scompreaske & in $x$ & $\mathrm{com}$ & & & \\
\hline & sasis & $\mathbf{m a}$ & $\cos \theta$ & $\operatorname{tran} f$ & compa & minta \\
\hline & Sol. Earearie: & $\operatorname{ten}$ & n torer & & & \\
\hline \multirow{5}{*}{$\begin{array}{l}\text { Q4) Armo o efetue: } \\
\text { a) } 32+27=\end{array}$} & esreft: & $b$ & si & op & & \\
\hline & sitentas & 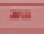 & $w$ & 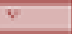 & & \\
\hline & cempreasesto & $\operatorname{tin}$ & eem & & & \\
\hline & $\operatorname{sen} 4$ & $m$ & $\cos \theta$ & $\operatorname{tran} /$ & eompa & $\operatorname{minta}$ \\
\hline & Wel. Earsaria: & ter & $n$ tent & & & \\
\hline \multirow{5}{*}{$\begin{array}{l}\text { Q5) Jutiana tem } 86 \text { adesivos e quer dar } 35 \text { para } \\
\text { sa ima. Com quantos adesivos Jusiana vas } \\
\text { fiear? }\end{array}$} & escrets: & $b$ & si & op & & \\
\hline & sifenches & $m$ & $\omega$ & $r$ & & \\
\hline & esomprataske & ine & $\cos$ & & & \\
\hline & сынын & va & $\cos \theta$ & trant & compas & minta \\
\hline & 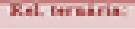 & $t=$ & $\mathbf{n}$ torer & & & \\
\hline \multirow{5}{*}{$\begin{array}{l}\text { Q5) Comprei } 25 \text { laranjas o distribui } 15 \text { com meus } \\
\text { amigos. Com quantas taranjas fiquei? }\end{array}$} & esreft: & $b$ & a & op & & \\
\hline & sirestat & 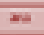 & $\omega$ & 8 & & \\
\hline & esmpreatesk & $\operatorname{inc}$ & eem & & & \\
\hline & Cane: & $m$ & comp & $\operatorname{tranat} f$ & eompa & mista \\
\hline & Kal. Earabia: & $t=$ & 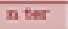 & & & \\
\hline \multirow{5}{*}{$\begin{array}{l}\text { Q7) Na sala de aula tem } 36 \text { cadeiras. } 5 \text { eadeiras } \\
\text { foram para o avditorio. Quantas cadeiras ficaram } \\
\text { na sala de aula? }\end{array}$} & sarefs: & $b$ & si & op & & \\
\hline & Difectate & $x$ & w & v & & \\
\hline & stepreteste & whe & $60 \mathrm{~m}$ & & & \\
\hline & glask & $m$ & हenes & Fanes & eempas & mista \\
\hline & Mal Earsaris: & ter & n terr & & & \\
\hline \multirow{5}{*}{$\begin{array}{l}\text { Q5) Arme e efetue: } \\
75-45 \text { : }\end{array}$} & cereft: & $b$ & si & op & & \\
\hline & vitenche: & su & $\mathbf{w}$ & $\mathrm{v}$ & & \\
\hline & semprestest & 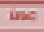 & $\cos$ & & & \\
\hline & thase & $=$ & cenesp & trand & cempas & mista \\
\hline & The tarkeris: & $E$ & nter & & & \\
\hline
\end{tabular}

A professora (P3) formulou 8 tarefas, sendo 6 situações e somente $2 \mathrm{com}$ o formato de solucionar a operação. As questões 1 e 2 (Q1, Q2) foram elaboradas com a ideia do campo multiplicativo e como nas análises anteriores, categorizamo-las como composições prototípicas. As outras questões (Q5, Q6 e Q7) foram estruturadas com a ideia da relação de transformação subtrativa prototípica defendida por Magina et al (2008), ou seja, em que se sabe o estado inicial e a transformação utilizada e busca-se o estado final, após a transformação com a ação subtrativa. Para analisar as tarefas elaboradas pela última professora (P4), tabulamos e analisamos os resultados do quadro 76. 
Quadro 6 - Tarefas elaboradas pela professora P4

\begin{tabular}{|c|c|c|c|c|c|c|}
\hline \multirow{6}{*}{$\begin{array}{l}\text { SITUACAO EI.ABORADA P4 } \\
\text { Q1) Maria ganhou } 37 \\
\text { figurinhas para eolar no } 8 \mathrm{eu} \\
\text { album. Ao retirar dos pacotes, } \\
\text { cla rasgou } 10 \text { figurinhas. } \\
\text { Quantas figurinhas restaram? }\end{array}$} & \multicolumn{6}{|l|}{ Chassincarto } \\
\hline & Tarefa: & B & Si & $O p$ & & \\
\hline & Situaçäo: & $A \mathrm{~B}$ & En & $\mathrm{v}$ & & \\
\hline & Compreensao & Inc & $\mathrm{Com}$ & & & \\
\hline & Classe: & $\mathrm{Au}$ & Comp & Iramar & Compa & Mista \\
\hline & Rel temana: & Ter & Niter & & & \\
\hline \multirow{5}{*}{$\begin{array}{l}\text { Q2) Arme e efetue as adiçoes: } \\
\text { a) } 24+12= \\
\text { b) } 44+23=\end{array}$} & Tarefa: & B & Si & क & & \\
\hline & Situaçiato: & Au & Un & $\mathrm{v}$ & & \\
\hline & Compreensa & Inc & com & & & \\
\hline & Classe: & $A \mathrm{AL}$ & Comp & Trans! & Compa & Mista \\
\hline & Rel, temana: & Ter & Nter & & & \\
\hline \multirow{5}{*}{$\begin{array}{l}\text { Q3)Joâ tem RS } 12,00 \text { e Maria } \\
\text { RS } 6,00 \text {. Quantos reais eles tèm } \\
\text { juntos? }\end{array}$} & Tarefa: & B & Si & $\infty$ & & \\
\hline & Sifuacao: & An & Un & $\mathrm{V}$ & & \\
\hline & Compreensio & Inc & Com & & & \\
\hline & Classe: & $\mathrm{Au}$ & Comp & Transf & Compa & Mista \\
\hline & Rel. ternaria: & Tex & Ner & & & \\
\hline \multirow{5}{*}{$\begin{array}{l}\text { Q4) Arme } \\
\text { subtraçoes: } \\
\text { a) } 54-12= \\
\text { b) } 36-22=\end{array}$} & Tarefa: & B & Si & $\omega_{0}$ & & \\
\hline & Situaçăo: & $A 13$ & En & $\mathrm{V}$ & & \\
\hline & Compreensáo & Inc & $\mathrm{com}$ & & & \\
\hline & Classe: & $A B$ & Comp & Transf & Compa & Mista \\
\hline & Rel. temaaria: & Ter & N ter & & & \\
\hline \multirow{5}{*}{$\begin{array}{l}\text { Q5) Fâbio tem } 15 \text { bolinhas de } \\
\text { gude e Joana tem } 5 \text { bolinhas. } \\
\text { Quantas bolinhas de gude têm } \\
\text { os dois juntos? }\end{array}$} & Tavefa: & B & Ss & $\infty_{0}$ & & \\
\hline & Sifuaçao: & $A n$ & Un & $\mathrm{v}$ & & \\
\hline & Compreensao & Inc & $\mathrm{com}$ & & & \\
\hline & Classe: & $\mathrm{Al}$ & Cons & Tranif & Compa & Mista \\
\hline & Kel. cermaria: & Tet & Nter & & & \\
\hline \multirow{5}{*}{$\begin{array}{l}\text { Q6) Régis ganhou do seu pai } \\
\text { RS } 28,00 \text {, mas ele perdeu RS } \\
12,00 \text {. Quantos reais restaram } \\
\text { para Régis? }\end{array}$} & Tarefa: & B & Ss & op & & \\
\hline & Situaçao: & $\mathrm{Au}$ & Un & $\mathrm{v}$ & & \\
\hline & Compreensáo & Ine & $\mathrm{Com}$ & & & \\
\hline & Classe: & Als & Comp & Tranif & Compa & Mista \\
\hline & Rel. ternaria: & Ter & N ter & & & \\
\hline \multirow{5}{*}{$\begin{array}{l}\text { Q7) Fui a feira o comprei } 02 \\
\text { bananas, } 03 \text { maças e } 01 \\
\text { abacaxi. Quantas frutas foram } \\
\text { compradas? }\end{array}$} & Tarefa: & B & II & m & & \\
\hline & Siruaçăo: & $\mathrm{Au}$ & Un & $\mathrm{v}$ & & \\
\hline & Compreensalo & Inc & Com & & & \\
\hline & Classe: & $A_{B}$ & Comp & Transf & Compa & Mista \\
\hline & Rel. termaria: & Ter & Niter: & & & \\
\hline \multirow{5}{*}{$\begin{array}{l}\text { QS) Fui à loja C7S o comprei } \\
\text { uma televisão que custou RS } \\
54,00 \text { e um aparelho de DVD } \\
\text { que custou RS } 12,00 \text {. Quanto } \\
\text { gastei na loja C7S com essas } \\
\text { compras? }\end{array}$} & Tarefa: & B & $5 i$ & $\infty$ & & \\
\hline & Situaçào: & AL & $u_{n}$ & $\mathrm{v}$ & & \\
\hline & Compreensao & Inc & Com & & & \\
\hline & Classe: & $\mathrm{Au}$ & Comp & Iranar & Compa & Neista \\
\hline & Rel, termaria: & Ter & Nter & & & \\
\hline
\end{tabular}

Analisando os dados apresentados pela professora P4, percebemos que houve variações nas questões propostas. A P4 elaborou 8 tarefas que eram 6 situações contextualizadas e 2 tarefas com formato de resolução de operação. Quatro questões (Q3, Q5 e Q7) foram feitas sobre a relação de composição, contudo a questão 8 (Q8) foi elaborada com a ideia de composição de transformação, ou seja, no caso ocorreu a composição de duas transformações. Três dessas (Q3, Q5 e Q7) foram formuladas de maneira prototípica em que conhecemos as partes e queremos

descobrir o todo. Um dado relevante é que essa professora formulou a questão 8 com a ideia bem mais complexa, que é a composição de transformações, que categorizamos com base em Magina et al (2008) de mista como podemos constatar ao analisá-la. Tivemos uma questão de transformação subtrativa prototípica, que se sabia o estado inicial e a transformação e buscava-se o estado final após a transformação que é a questão 6 (Q6).

Verificando os dados das quatro professorass observamos que das 32 questões elaboradas pelas professoras, 25 eram situações e as 7 restantes eram formuladas no algoritmo de "arme e efetue" que caracterizamos como operações. Além disso, percebemos que excetuando a P2, as outras ainda utilizavam dessa estratégia em suas formulações. P3 e P4 elaboraram cada uma, 2 questões assim, enquanto a P1 criou 3 questões.

Quando analisamos os tipos de situações criadas, dentre as 25 questões, precisamos que as relações de base defendidas por Vergnaud e seus seguidores como Magina et al (2008) as mais utilizadas pelas professoras em sua maioria foi a composição, aquela que é ofertada as partes e deseja-se descobrir o todo, excetuando a P3 que formulou igualmente questões de composição e de transformação. Outro fator relevante é que não foi gerada nenhuma questão com a ideia de comparação.Podemos destacar ainda que as composições prototípicas têm um destaque maior sobre os outros tipos de relações de base. No caso da P1 observamos que as suas formulações estão calcadas exclusivamente nas prototípicas, sendo que somente 1 é do modelo de transformação. No caso da P2 a sua maioria é realmente a composição prototípica, contudo ela consegue formular uma questão de composição de 1a extensão. No caso da P3 as suas questões elaboradas estão igualmente divididas entre as prototípicas de composição e 
transformação. Quanto a P4, observamos que ela teve uma variedade maior, pois formulou 2 questões de prototípicas de composição e 2 de transformação. Também formulou uma composição de transformações.

\section{CONSIDERAÇÕES FINAIS}

As respostas do grupo investigado nos mostraram que, mesmo considerando que todas cursassem especialização e a disponibilidade das professoras em aprender, nenhuma delas teve contato anterior com a TCC. Ao criar as questões observamos que as questões elaboradas eram de composições e transformações em sua maioria prototípicas, ou seja, que têm como objetivo uma ação elementar que é saber as partes e descobrir o todo, ou no caso das transformações, sabemos o estado inicial e o final e queremos descobrir a transformação seja ela aditiva ou subtrativa. 0 que nos parece preocupante, uma vez que estudos apoiados em Vergnaud nos mostram a necessidade de o professor proporcionar aos estudantes possibilidades de trabalho com diferentes situações.

Consideramos, assim como Ball et al (2008), que esse desconhecimento do conteúdo, possivelmente compromete os conhecimentos: do Conteúdo e do Estudante; do Conteúdo e do Ensino e o Curricular, entretanto, é importante chamar a atenção para o fato que os resultados aqui apresentados refletem o domínio das participantes sobre as estruturas aditivas, no início da nossa investigação. Nesse sentido, cabe ressaltar que durante o processo formativo observamos haver superação de algumas dessas concepções, todavia esses resultados apresentaremos em outro artigo. Dessa forma, a análise destes dados nos permitiu organizar o processo de formação. Nele apresentamos, já nos primeiros encontros, em linhas gerais, a biografia do Vergnaud e como ele estruturou a TCC e o CCA. Em seguida, realizamos um estudo teórico dos seus pressupostos e procuramos apoio também em autores que se referenciam em seus estudos como aportes, como Magina et al (2008). Objetivávamos com essa ação, levar resultados de pesquisa a fim favorecer a (re)significação do conhecimento profissional docente. Esperávamos com isso que as professoras pudessem promover em suas salas de aula situações variadas de aprendizagem em que os alunos tivessem contato com uma diversidade maior de situações.

Reiteramos que analisando os dados iniciais observamos que a maioria das situações elaboradas pelas professoras eram prototípicas e, segundo Vergnaud (2010), nesse tipo se situação os alunos utilizam-se de esquemas para resolvê-las, desenvolvidos antes de chegar à escola. Acreditamos ser importante que o professor que leciona para o terceiro ano perceba a necessidade de oferecer a esse estudante vivências de outras situações. Sobre isso, Vergnaud (2010), afirma: Se o conhecimento é adaptação, para as crianças aprenderem temos que desestabilizá-las. Se as crianças não têm motivo para se adaptar à situação nova, por que aprender? A infelicidade de tudo isso é que se desestabilizarmos demais as crianças, elas não vão aprender. (VERGNAUD, 2010, 1 DVD)7 ${ }^{7}$. Dessa forma, consideramos, assim como o autor citado, que a mediação do professor é fundamental nos processos de aprendizagem.

Nesse sentido, consideramos que o primeiro passo seria conhecer os pressupostos da teoria a fim de viabilizar a análise e o reconhecimento da classificação proposta por Vergnaud, observando os diferentes graus de dificuldade de cada tipo de situação.

\section{REFERÊNCIAS}

[1] Ball, D. L., Thames, M. H., \& Phelps, G. Content Knowledge for Teaching What Makes It Special? In: Journal of teacher education, p. 403, 2008.

[2] Etcheverria, T. C. 0 ensino das estruturas aditivas junto a professoras dos anos iniciais do Ensino Fundamental. Tese, (Doutorado em Educação Matemática) Universidade Anhanguera de São Paulo, São Paulo, 2014.

[3] Magina, S. A pesquisa em sala de aula de matemática das séries iniciais do ensino fundamental. Contribuições teóricas da psicologia. Educar em Revista, Curitiba, Brasil, n. Especial 1/2011, p. 63-75, 2011.

[4] Merlini, V. L; Magina, S; Santos, A. Estrutura Multiplicativa: Um Estudo Comparativo entre o que a professora elabora e o desempenho dos estudantes. Ata do VII Congresso Ibero-americano de Educação Matemática - VII CIBEM. Montevidéu, 2013.

[5] Miranda, M.S. Uma investigação sobre a (re)construção do conhecimento de professores participantes de um grupo que estuda o campo conceitual aditivo. Dissertação, (Mestrado em Educação Matemática) Universidade Anhanguera de São Paulo, São Paulo, 2014.

${ }^{7}$ Esta citação foi retirada do curso de altos estudos proferido por Gerard Vergnaud: Teoria dos Campos Conceituais: o estudo das estruturas multiplicativas em 2010 na UNIBAN (hoje Universidade Anhanguera). 
[6] Pinheiro, M.G.C. Formação de professores dos anos iniciais: conhecimento profissional docente ao explorar a introdução do conceito de fração. Dissertação, (Mestrado em Educação Matemática) ) Universidade Anhanguera de São Paulo, São Paulo, 2014.

[7] Vergnaud, G. Multiplicative structures. In Lesh, R. and Landau, M. (Eds.) Acquisition of Mathematics Concepts and Processes. New York: Academic Press Inc. pp. 127-174, 1983

[8] ___ Lev Vygotski. Pedagogo e pensador do nosso tempo. Porto Alegre: Geempa, 2004.

[9] __. Gérard. A criança, a matemática e a realidade. Curitiba: Editora UFPR, 2009.

[10]___ Escola de altos estudos. Teoria dos Campos Conceituais: o estudo das estruturas multiplicativas. São Paulo: Uniban, 2010. 1 DVD. 


\section{Capítulo 5}

\section{Um estudo sobre as concepções de professores do Ensino básico em relação à Aleatoriedade}

\section{Marcelo Rivelino Rodrigues}

Resumo: Neste artigo apresentamos a análise realizada a partir dos dados coletados, por meio de um questionário de Concepções Probabilísticas, que foi aplicado a um grupo de 184 professores do Ensino Básico do Município de São Paulo. Em nossa pesquisa buscamos identificar, no grupo de professores participantes, se estes reconhecem ou não, a ocorrência de eventos aleatórios nos mais diversos contextos, para posteriormente analisar os conjuntos de argumentações que os mesmos utilizaram em suas respostas. 0 reconhecimento da natureza aleatória de certos eventos, mostra-se indispensável para a construção de uma estrutura matemática como a Teoria da Probabilidade, além do fato de ser fundamental na formação e/ou atuação de professores que irão ensinar Matemática. As análises estatísticas desenvolvidas neste trabalho, foram possibilitadas pelo software de Classificação Hierárquica, Implicativa e Coesitiva (C.H.I.C). A partir dos resultados foi possível realizar a identificação de diferenças significativas entre a afirmação e a negação da aleatoriedade dos eventos incertos. Nossa pesquisa está fundamentada nos trabalhos de Azcárate que categorizou os Pensamentos Probabilísticos, de Cardeñoso que categorizou as Concepções Probabilísticas e de Gal que apresentou a definição para Letramento Probabilístico. Em nossa análise identificamos professores que, em suas argumentações, apresentaram indícios de concepções que não lhes permitem abordar adequadamente o ensino de Probabilidade.

Palavras-chave: Probabilidade; Aleatoriedade; Concepções; Crenças; Letramento Probabilístico. 


\section{INTRODUÇÃO}

A Probabilidade é sem dúvida, uma ferramenta poderosa quando nos encontramos em situações, onde devemos tomar decisões baseadas em informações de acontecimentos semelhantes àquele a qual estamos vivendo. Ou até mesmos, quando não possuímos informações prévias de determinado assunto, e desta forma, apoiados em nossas experiências pessoais, conseguimos avaliar dentre os resultados possíveis, para a tomada de decisões, aquele ou aqueles que mais atenderão aos nossos objetivos e interesses. A aleatoriedade está na estrutura da concepção de Probabilidade, uma vez que grande parte dos eventos são de caráter aleatórios e, em contrapartida, poucos são de caráter determinísticos. Segundo Azcárate, Cardeñoso e Porlán, a aleatoriedade:

Sendo o núcleo do conhecimento probabilístico, é considerada habitualmente como um conceito 'óbvio' e seu significado não é analisado com profundidade. Porém, podemos supor que determinados tipos de concepções sobre ela podem ser um claro obstáculo para a compreensão da natureza probabilística de certos aspectos da realidade (Azcárate, Cardeñoso e Porlán, 1998, p.86 - tradução nossa).

A importância da noção de aleatoriedade encontra-se no fato, desta ser um conceito que está diretamente envolvido com a nossa própria maneira de conceber a realidade e conhecimentos. Como analisa Kyburg:

É um conceito relacionado com nosso corpo de conhecimento, que de alguma forma reflete o que sabemos e o que não sabemos (Kyburg, 1974, p.217, Apud Azcárate, Cardeñoso e Porlán, 1998, p. 86 - Tradução nossa)

Partindo deste princípio, iremos expor parte da nossa pesquisa que está em andamento.

Primeiramente iremos apresentar um panorama das discussões atuais sobre os rumos que a educação brasileira deverá tomar nos próximos anos, trazendo uma breve análise dos documentos oficiais que tratam sobre a organização curricular no Brasil. Em seguida, apresentamos a análise bibliográfica que respaldou a nossa pesquisa.

\section{Panorama atual da Educação no Brasil}

No momento em que a Educação Básica brasileira passa por um processo de integração do seu currículo, entendemos o quão oportuno é que pesquisas voltadas para esse ciclo de ensino se intensifiquem.

Dentre as linhas de pesquisas que estão em curso, destacamos aquelas cujos focos estão na formação de professores, pois nos encontramos com a oportunidade ímpar de promovermos mudanças significativas nessa área, uma vez que o Ministério da Educação e Cultura (MEC), neste momento histórico, debruça-se na elaboração de um documento que visa a unificação do currículo da Educação Básica no Brasil e que fala sobre a formação de professores.

\section{Base Nacional Comum Curricular}

A ideia de um documento que unificasse os conteúdos da Educação Básica no Brasil já fora sugerida na Constituição de 1988, pois em seu Artigo 210, a nossa Carta Magna prevê a criação de uma grade curricular de conteúdos fixos a serem estudados no Ensino Fundamental.

Posteriormente na Lei de Diretrizes e Bases da Educação Nacional de 1997, foram apresentados os Parâmetros Curriculares Nacionais para o Ensino Fundamental e Médio, cujo objetivo não foi o de criar um currículo único para a Educação Básica, mas sim o de oferecer subsídios para os conhecimentos que deveriam ser abordados nos referidos níveis de ensino.

Em 2014 ocorreu a publicação do Plano Nacional de Educação (PNE), para o decênio de 2014 à 2024, nele consta as 20 metas a serem alcançadas no período estabelecido. Em sua meta de número 7, o PNE visa o estabelecimento e implantação, mediante à pactuação interfederativa, das Diretriz Pedagógicas para a Educação Básica e a elaboração da Base Nacional Comum Curricular, com direitos e objetivos de aprendizagem e desenvolvimento dos (as) alunos (as) para cada ano do Ensino Fundamental e Médio, respeitada a diversidade regional, estadual e local.

Um dos objetivos da BNCC será o de reduzir as desigualdades educacionais do país. No texto de apresentação da BNCC, o Ministério da Educação e Cultura enfatiza que dois rumos importantes surgirão após a aprovação da base.

0 primeiro diz respeito à formação, tanto inicial quanto continuada dos professores e o segundo, se refere ao material didático, pois na visão do MEC ambos deverão passar por mudanças significativas. 
Apoiado nesta perspectiva de mudanças significativas, nos colocamos a analisar o que os documentos oficiais, PCN's e BNCC, apresentam em relação ao tema Probabilidade, pois, no que tange os conteúdos matemáticos para Ensino Básico, a Probabilidade é um dos campos que tem merecido destaque, ora por sua inestimável importância para uma formação cidadã, ora por sua capacidade de viabilizar um maior entendimento do mundo ao nosso redor. Assim, este tema se apresenta como uma terra fértil para pesquisas de toda sorte.

\section{A Probabilidade nos documentos oficiais}

Nos Parâmetros Curriculares Nacionais, o tema Probabilidade encontra-se no campo denominado Tratamento da Informação, que engloba os conhecimentos de Contagem, Probabilidade e Estatística. Segundo os PCN's, esse conteúdo do conhecimento Matemático deverá ser abordado a partir do Ensino Fundamental. Com essa orientação nos PCN's, pela primeira vez, um documento oficial trazia em suas páginas, a indicação para o Ensino da Probabilidade também nas séries iniciais.

Corroborando com essa ideia, a Base Nacional Comum Curricular, em seu documento introdutório da área de Matemática, prevê para todas as séries que compõem o Ensino Básico a abordagem desse conteúdo.

Considerando o fato de que em maio de 2016, o Ministério da Educação e Cultura apresentou a segunda versão do documento da Base Nacional Comum Curricular, e que neste momento, o mesmo encontra-se na sua terceira revisão, por ora optamos por nos pautar apenas nos documentos vigentes, ou seja, os Parâmetros Curriculares Nacionais.

Devido aos contornos da vida moderna em sociedade, os PCN's nos apontam para possibilidade/necessidade, de abordar o tema Probabilidade desde os anos iniciais. Nessa perspectiva, iniciamos a nossa pesquisa que versa sobre as concepções probabilísticas dos professores que atuam no Ensino Básico. 0 nosso ponto de partida foi realizar uma análise bibliográfica dos trabalhos que tinham por tema o Ensino e Aprendizagem de Probabilidade.

\section{ANÁLISE BIBLIOGRÁFICA}

Na pesquisa realizada em 2015, Santos analisou as Teses e Dissertações que versam sobre o tema Educação Estatística junto ao Banco de Teses e Dissertações da CAPES e também, junto à Biblioteca Digital Brasileira de Tese e Dissertações (BDTD). Dos trabalhos encontrados pelo autor, apenas 17 deles estavam relacionados com a temática das concepções, competências, percepções e representações sobre os temas Estatística, Probabilidade e Contagem.

Coutinho (2013) ao analisar as Teses e Dissertações que abordaram este assunto pelo viés do conteúdo, do aluno e do professor, constatou que os trabalhos realizados sobre esses temas, aparecem em um número muito reduzido se compararmos com outros conceitos Matemáticos, por exemplo a Educação Estatística e a Matemática Financeira.

Por essas razões a nossa pesquisa se debruça sobre o tema Ensino e Aprendizagem de Probabilidade, com foco nos professores do Ensino Básico.

Buscamos analisar os conhecimentos, conceitos e crenças de professores que atuam neste nível de ensino apresentam, quando os mesmos respondem a um questionário de concepções probabilísticas.

Neste presente artigo, trazemos uma análise dos dados coletados junto a um grupo de 41 professores de Matemática do Ensino Fundamental II, em relação ao reconhecimento de eventos aleatórios inseridos em diversos contextos.

\section{PROCEDIMENTOS METODOLÓGICOS}

Na construção de nossa pesquisa, mais precisamente no que diz respeito à coleta e análise dos dados, realizamos os seguintes procedimentos:

- Adaptamos para a nossa realidade, o instrumento de coleta de dados denominado "Questionário de Concepções Probabilísticas" (QCP), que foi elaborado por Cardeñoso (1998);

- Definimos o grupo de professores que iriam participar de nossa pesquisa;

- Utilizando o software Excel da Microsoft para tabular os dados coletados; 
- Submetemos os dados tabulados ao software Classificação Hierárquica, Implicativa e Coesitiva, afim de obter os gráficos de coesão, implicação e similaridade.

- Analisamos os gráficos obtidos à luz das Concepções Probabilísticas definidas por Cardeñoso (1998).

\section{REFERENCIAL TEÓRICO}

Na fase de elaboração/adaptação do instrumento de coleta de dados, como também nas fases de tratamento e análise dos dados obtidos, estivemos sempre pautados na definição de "contexto", apresentada por Azcárate (1995) e defendida por Cardeñoso (1998).

Em nossa pesquisa, utilizamos o termo "contexto" como o ambiente físico ou situacional (conjunto de circunstâncias), a partir do qual se considera um fato. Neste sentido trazemos como exemplo uma situação de análise de informações no "contexto de jogos", ou seja, a ideia central da situação apresentada, está centrada no ambiente de jogos.

Segundo Azcárate, Cardeñoso e Porlán (1998), o contexto mantem uma significativa influência nas argumentações dos sujeitos. De acordo com esses autores:

0 próprio contexto em que está imersa a situação, a experiência sobre o contexto e o significado que esta situação particular tem para eles, determinam os julgamentos ou decisões sobre o assunto, pelo qual pensamos que a justificação do indivíduo, pode nos fornecer informações mais precisas sobre os seus argumentos de discriminação que estabelece um critério geral de aleatoriedade, aplicável nas distintas situações. (Azcárate, Cardeñoso e Porlán, 1998, p. 90 - Tradução nossa)

Em nosso instrumento de coleta de dados, optamos por apresentar os eventos aleatórios imersos em três contextos: Jogos, Cotidiano e Físico/Natural.

Cardeñoso (1998) apresentou em sua pesquisa, uma categorização das Concepções Probabilísticas. Essa categorização foi possibilitada pela análise dos dados coletados junto ao grupo de professores que responderam ao Questionário de Concepções Probabilísticas.

Ele dividiu em duas dimensões as concepções observadas: Dimensão Aleatoriedade e Dimensão Probabilidade. Neste artigo utilizaremos a categorização da Dimensão Aleatoriedade. Essa dimensão apresenta cinco grupos assim definidos:

Causalidade: Argumentação que tem como critério de reconhecimento da aleatoriedade, explicações em função dos diversos fatores causais ou, na ausência de possibilidade de seu controle.

Multiplicidade: Argumentação que tem com critério de reconhecimento da aleatoriedade, a existência de múltiplas possibilidades no desenvolvimento do fenômeno.

Incerteza: Argumentação na qual se utiliza como critério de reconhecimento da aleatoriedade, a própria imprevisibilidade do evento, sem aprofundar na sua explicação ou análise.

Subjetividade: Argumentação na qual se utiliza como critério de reconhecimento da aleatoriedade, considerações referidas à própria vivência ou crenças subjetivas.

\section{ANÁLISE DOS DADOS}

O primeiro gráfico traz a porcentagem de professores do Ensino Fundamental II que reconhecem ou não, os eventos apresentados como aleatórios. 
Figura 1: Gráfico de reconhecimento da Aleatoriedade de um evento em relação ao contexto

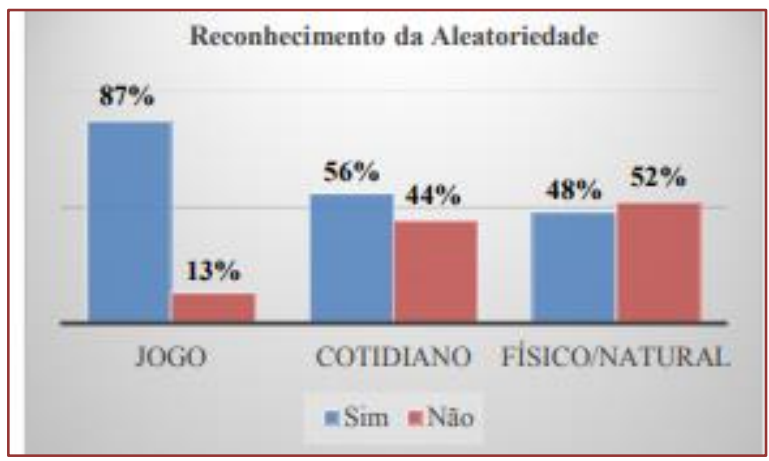

Fonte: Autor (2016)

Podemos observar que o reconhecimento de eventos aleatórios está aparentemente relacionado à ideia de contexto, pois claramente identificamos um decréscimo relevante do reconhecimento, por parte desses professores, de eventos aleatórios quando comparamos os contextos de Jogos e do Cotidiano. E essa diferença aumenta quando comparação se dá entre os contextos Jogos e Físico/Natural.

Estes fatos nos direcionam à possibilidade da influência dos conteúdos dos livros didáticos, que apresentam as situações de eventos aleatórios quase que exclusivamente no contexto de Jogos. Em seus trabalhos, Lajolo (1996) e Gonçalves (2004), apontam uma forte influência dos livros didáticos nas práxis dos professores, principalmente os professores do Ensino Básico, que têm no livro didático a sua principal, quando não única, fonte de conteúdo e conhecimentos.

Outro ponto que podemos destacar, está relacionado à definição de Letramento Probabilístico trazida por Gal (2005), onde o autor destaca a necessidade de identificar ocorrência de eventos aleatórios nos mais diversos contextos.

Em uma das nossas questões de pesquisa, fazemos a seguinte indagação: Os professores do Ensino Básico reconhecem maioritariamente os fenômenos aleatórios?

Entendemos que em relação a esse grupo de professores analisados, podemos concluir que os mesmos não apresentam um reconhecimento de eventos aleatórios satisfatório, quando estes aparecem em contextos distintos ao de Jogos.

Como agravante ressaltamos que esses professores possuem graduação em Matemática e, que em sua maioria, ministram aulas a mais de uma década para esse nível de ensino.

Análise do nó significativo do nível 1

0 grafo a seguir apresenta o nó significativo do nível 1.

Figura 2: Grafo de similaridades 1

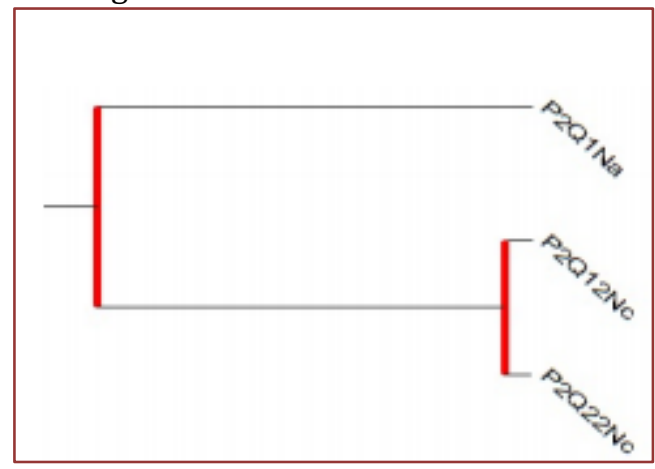

Fonte: Autor (2016) 
Devemos observar que os nós significativos têm as suas probabilidades entre 0 e 1 . A probabilidade do nível 1 alcançou o valor de 0,989, ou seja, existe uma grande chance de que o resultado apontado por este nó de fato venha ocorrer.

As tipicalidades desta classe (nível 1) apresenta a relação existente entre os itens P2Q12Nc e P2Q22Nc, ambos relacionados à dimensão aleatoriedade. Para as questões que compõe a dimensão aleatoriedade, tem-se como possibilidades de respostas as alternativas dos tipos: Aleatório (A) e Não Aleatório (N). Cada uma dessa alternativas dispunha de quatro opções de justificativas sendo que três dessas opções eram do modelo de questões fechadas e uma do modelo de questões abertas.

A variável típica desta classe é P1Q12b com risco de 0,0404, valor este que indica um baixo risco de tal acontecimento não ocorrer. A característica principal desta variável, está relaciona aos professores que não fizeram nenhum curso de pós-graduação, independentemente do tempo de atuação no magistério.

O item P2Q12Nc, que está inserido no contexto do Cotidiano, traz a seguinte questão: "Prever a próxima ideia que vem à mente é um evento...", (A) Aleatório e (NA) Não Aleatório?

O item oferece as seguintes opções de argumentações na Dimensão Aleatoriedade:

a) Causalidade: Porque ela depende do que acontecer, as relações entre ideias, o que me preocupa, o que havia pensado antes.

b) Incerteza: Porque eu não posso saber o que vai acontecer comigo depois de um tempo.

c) Multiplicidade: Porque à mente veem muitas ideias que você sequer está pensando.

d) Subjetividade: Porque, na minha opinião...

$\mathrm{O}$ item P2Q22Nc do contexto Físico-Natural, traz a seguinte questão: "Sofrer uma indigestão é um fenômeno...", (A) Aleatório e (NA) Não Aleatório?

a) Causalidade: Porque é um produto de muitas coisas, do tipo de alimento, uma mudança de temperatura, de um banho,...

b) Multiplicidade: Porque eu posso sofrer depois de uma refeição muitos contratempos, incluindo uma indigestão.

c) Incerteza: Porque é possível que ocorra, no entanto, não poderei saber com certeza.

d) Subjetividade: Porque, na minha opinião...

Em uma primeira análise podemos observar que este grupo de professores apresentam uma certa dificuldade de reconhecer como aleatórios eventos pertencentes ao contexto do Cotidiano. 0 mesmo ocorre quando o contexto abordado passa a ser o Físico/Natural. De forma contraditória, em suas argumentações, esses professores pautam-se ora na multiplicidade de possibilidades da ocorrência do evento, ora na própria imprevisibilidade do evento, ou seja, não reconhecem os eventos com aleatórios mas usam argumentações pautadas na própria incerteza apresentada no evento.

Análise do nó significativo do nível 8 relacionado com o nível 11

O próximo gráfico traz o nó significativo onde os professores que assim responderam, demonstraram ter dificuldades aparentes em reconhecer a ocorrência de eventos aleatórios nos contextos utilizados. Nos chama a atenção que para o item P2Q16AdAc, do contexto de Jogos, apresenta o reconhecimento da aleatoriedade com argumentações apoiadas na Causalidade e Subjetividade, em contrapartida no item P2Q17NbNa, inserido no mesmo contexto, não ocorreu o reconhecimento da aleatoriedade do evento. 
Figura 3: Grafo de similaridades 2

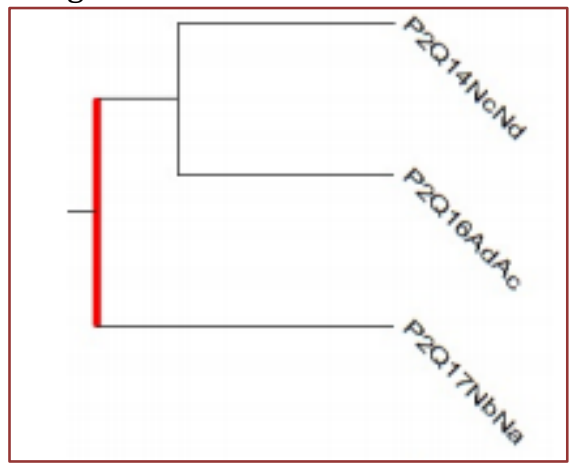

Fonte: Autor (2016)

Reconhecem o evento como aleatório no item P2Q16AdAc: "Prever a quantidade de caras que se obtém em 100 lançamentos de uma moeda é um fenômeno..."

Não reconhecem o evento como aleatório no item P2Q17NbNa: "Prever a cor de uma bola que é extraída de uma urna com bolas de diferentes cores é um fenômeno..."

Item P2Q14NcNd: "A germinação de uma semente plantada é um fenômeno...".

Este item está inserido no contexto Físico/Natural. 0 não reconhecimento de evento aleatório, pelos professores pesquisados, corrobora com o que foi apontado por Cardeñoso (1998) em seu trabalho. 0 autor observou que um número muito elevado de professores, participantes de sua pesquisa, também não reconheceram os eventos aleatórios nos contextos Físico/Natural. Este fato levou o autor concluir que, a falta de clareza da ideia de aleatoriedade em contextos fora daquele que mais aparecem nos livros didáticos, torna-se um obstáculo para o reconhecimento de eventos aleatórios.

Em nossa pesquisa observamos que o reconhecimento de eventos aleatórios, ocorreu com maior frequência quanto estes pertenciam ao contexto de Jogos. Por outro lado, o reconhecimento da aleatoriedade por parte esses professores pesquisados, se mostrou muito aquém do esperado, quando o evento observado estava atrelado aos contextos do Cotidiano e Físico/Natural.

Entendemos que esse grupo de professores que atuam no Ensino Fundamental II, apresentam um grau elevado do não reconhecimento de eventos aleatórios nos contextos do Cotidiano e Físico/Natural. No entanto, quando os mesmos ocorrem no contexto de Jogos o reconhecimento ocorre com uma frequência maior. Esta evidência pode ter relação s o reconhecimento ocorre com uma frequência maior. Esta evidência pode ter relação com o fato de que, o contexto Jogos, como afirma Rodrigues (2016), é predominante nos Livros Didáticos aprovados pelo Plano Nacional do Livro Didático para os próximos anos.

Queremos ressaltar, que os professores que fazem parte deste grupo analisado, possuem a sua formação em Matemática, pois a graduação na área de atuação é uma exigência da Rede de Ensino da qual eles fazem parte.

\section{CONCLUSÕES}

Com esse trabalho esperamos colaborar com a intensificação do debate no campo da Educação Estatística, particularmente no que se refere à formação inicial e continuada dos professores que ensinam Matemática, com foco em professores que atuam no Ensino Básico, trazendo informações a respeito das Concepções Probabilísticas e do Letramento Probabilísticos, bem como na elaboração de materiais didáticos que possam auxiliar de forma significativa o ofício docente. 


\section{REFERÊNCIAS}

[1] Almouloud, S.A. (2015). O que está por detrás do Chic. In Valente, J. A. e Almeida, M. E. B. (org.). 0 uso do Chic na formação de educadores. pp.42-60. Rio de Janeiro: Letra Capital.

[2] Anped. (1996). Parecer da Anped sobre os parâmetros curriculares nacionais. Revista Brasileira de Educação, São Paulo, n. 2. p. 85-92.

[3] Azcárate, P. (1995). El conocimiento profesional de los profesores sobre las nociones de aleatoriedad y probabilidad: su estudio en el caso de la educación primaria. 1995. Tese (Doutorado em Didática) -Universidad de Cádiz, Cádiz.

[4] Batanero, C., Henri, M., Parzysz, B.I. (2005). The Nature of Chance and Probability. En G. Jones (Ed.), Exploring probability in school: Challenges for teaching and learning (pp. 15-38). New York: Springer.

[5] Bogdan, R.C., Biklen, S. K. (1994). Investigação qualitativa em educação: uma introdução à teoria e aos métodos. Porto: Porto Editora. (Coleção ciências da educação).

[6] Cardeñoso, J.M.D. (1998). Las creencias y conocimientos de los professores de primaria Andaluces sobre la matemática escolar. Modelización de Concepções sobre la Aleatoriedad y Probabilidad. Cadiz, España. Tesis Doctoral. Universidad de Cádiz.

[7] Coutinho, C.Q.S. (1994). Introdução ao conceito de probabilidade pela visão freqüentista - estudo epistemológico e didático. São Paulo. Dissertação de Mestardo. Pontifícia Universidade Católica de São Paulo.

[8] Coutinho, C.Q.S. (2013). Introdução ao conceito de probabilidade e os livros didáticos para Ensino Médio no Brasil. Educación Estadística en América Latina: Tendencias y Perspectivas, Caracas - Venezuela (p. 193 - 210).

[9] Gal, I. (2005). Towards "probability literacy" for all citizens: Building blocks and instructional dilemmas. En G. Jones (Ed.), Exploring probability in school: Challenges for teaching and learning (pp. 39-63). New York: Springer.

[10] Gras, R., Almouloud, S.A. A implicação estatística usada como ferramenta em um exemplo de análise de dados multidimensionais. Revista Educação Matemática Pesquisa. São Paulo: Educ, v. 4, n. 2, 2002, p. 75-88

[11] Lopes, C.A.E. (2003). O conhecimento profissional dos professores e suas relações com estatística e probabilidade na educação infantil. 2003. Tese. (Doutorado) - Faculdade de Educação, Universidade Estadual de Campinas, Campinas.

[12] Morgado, A.O.C. et al. (1991). Análise e probabilidade. Rio de Janeiro: Sociedade Brasileira de Matemática.

[13] Oliveira, P.C. (2003). O processo de aprender noções de probabilidade e suas relações no cotidiano das séries iniciais do ensino fundamental: uma história de parceria. 2003. Tese. (Doutorado em Educação Matemática). Faculdade de Educação, Universidade Estadual de Campinas, São Paulo.

[14] Rodrigues, M.R. (2007). A Urna de Bernoulli como modelo fundamental de ensino de probabilidade. 2007. Dissertação (Mestrado em Educação Matemática) - Pontifícia Universidade Católica de São Paulo, São Paulo.

[15] Rodrigues, M.R. (2015). A Urna de Bernoulli como modelo fundamental de ensino de probabilidade. Coleção do V Seminário Nacional de Histórias e Investigações de/em Aulas de Matemática, Grupo de Sábado - GdS, Universidade Estadual de Campinas, SP

[16] Rodrigues, M.R., Martins. E.G. (2016). A abordagem do tema probabilidade nos livros aprovados pelo PNLD para o triênio 2015 - 21017 e suas implicações no processo de ensino e aprendizagem. Anais do XII ENEM - Encontro Nacional de Educação Matemática, Universidade Cruzeiro do Sul, São Paulo, São Paulo.

[17] Santos, R.M. (2015). Estado da arte e história da pesquisa em Educação Estatística em programas brasileiros de Pós-Graduação, 348f. Tese (Doutorado em Educação) - Universidade Estadual de Campinas. 


\section{Capítulo 6}

\section{Um problema no ensino da matemática: aprendizado das frações}

\section{Maria Inmaculada Chao Cabanas}

Resumo: 0 estudo analisa um dos problemas cruciais no contexto da matemática escolar: o aprendizado das frações pelos estudantes da educação básica. Embora seja uma temática recorrente em pesquisas e análises de itens de avaliações em larga escala, verifica-se a necessidade de identificar o que orienta os discursos que justificam o fracasso dos alunos quando se deparam com o aprendizado desses números. 0 diálogo entre diferentes autores que estudam a problemática do aprendizado das frações e que são referência para o ensino da matemática, bem como itens e descritores de provas em larga escala, constituíram o material de análise no sentido de identificar comparativamente o que sustenta as escolhas metodológicas no ensino das frações e o que orienta a elaboração dos itens dos exames. Desse modo, as considerações decorrentes da análise das justificativas a respeito das diferentes dificuldades dos alunos no aprendizado das frações, realizadas a partir de revisão bibliográfica de inúmeros estudos e investigações sobre o tema, e o que consideram os descritores e itens da Prova Brasil em relação à proficiência nesses números, nos permitem inferir que a dificuldade dos alunos quando se deparam com as frações advém do modo como esse número é ensinado, o que parece ser determinado pelos exames. 


\section{INTRODUÇÃO}

O problema da dificuldade dos alunos no aprendizado dos números racionais é uma discussão recorrente em pesquisas que tratam do ensino da matemática escolar e documentos que orientam sistemas de ensino. É também comum a estes estudos e orientações propor estratégias metodológicas como um caminho possível para reverter supostos fracassos dos alunos na aprendizagem desses números.

Estas dificuldades são também expostas nos documentos que organizam os resultados das avaliações em larga escala, como Prova Brasil, SAEB, entre outras, e que analisam como insatisfatório o aprendizado dos números racionais pelos alunos da escola básica, apontando para ausências conceituais no ensino desses números.

No entanto, o que se observa nos resultados dos estudos e nas propostas metodológicas que decorrem destes é a ênfase no modo de como se espera que o estudante pense e não no porquê de pensar da maneira como o faz, o que acreditamos que poderia contribuir para a identificação de ausências também no modo de ensinar.

Assim, pela recorrência da problemática com o aprendizado das frações identificada tanto nas pesquisas que tratam do ensino e da aprendizagem desses números no ensino fundamental como nos documentos das avaliações em larga escala, justifica-se a necessidade da revisão dos discursos presentes nesses materiais no sentido de identificar o que orienta esses discursos.

Deste modo, a apresentação do diálogo entre diferentes autores e documentos orientadores do ensino da matemática, a partir dos pressupostos conceituais que adotam, podem tornar possível identificar as insuficiências presentes nas redes conceituais que sustentam escolhas metodológicas no ensino desses números e também, por que não, no que orienta a elaboração dos itens dos exames.

\subsection{S ESTUDOS REVISADOS}

Carvalho e Ponte (2016) investigaram o desenvolvimento de estratégias de cálculo mental com números racionais utilizando o que eles chamam de metodologia da Investigação Baseada em Design (IBD) e que se caracteriza pelo refinamento de projetos educacionais com base na experimentação de uma sequência de tarefas, análise dos resultados para então propor novas situações, sempre com base nessas experiências. Esta mesma metodologia é também estudada por Cobb, Jackson e Dunlap (2016), apud Carvalho e Ponte (2016).

Brown (1992) e Collins (1992) denominam a metodologia de "Pesquisa Baseada em Design" (PBD) e foram os responsáveis por introduzir este referencial no campo educacional a partir do conceito de "design experiments". Esta abordagem, ganha importância na pesquisa educacional a partir de crescente produção acadêmica, adotada por diversos grupos de pesquisa e designada por uma variedade de termos (design experoments, developmental research, design research e design based research).

Carvalho e Ponte (2016) justificam o uso da IBD por considerá-la potencialmente favorável ao desenvolvimento de estratégias de cálculo mental com números racionais e, para tanto, utilizam aspectos que orientam as experiências e funcionam em conjunto para apoiar a aprendizagem. 0 estudo teve como objetivo perceber as estratégias e erros no cálculo mental com números racionais dos alunos do 5o. ano de escolaridade, e dinâmicas referentes à realização de uma experiência de ensino centrada em tarefas de cálculo mental e na discussão coletiva dessas tarefas, aperfeiçoadas em dois ciclos de experimentação, em 2012 e 2013. Os autores organizam as dificuldades dos alunos a partir da evolução das estratégias que estes apresentam na resolução das questões que lhes são propostas. A partir dos erros evidenciados, são propostas novas tarefas orientadas com base na investigação. 
O Quadro 1 a seguir ilustra um recorte da investigação realizada por Carvalho e Ponte (p. 321-323)

\begin{tabular}{|c|l|}
\hline \multirow{2}{*}{ Dificuldade identificada } & $\begin{array}{l}\text { "Cálculo de } 1 / 2+1 / 2 \text { " } \\
\text { Resultado apresentado: } \\
{[2 / 4]}\end{array}$ \\
\hline $\begin{array}{c}\text { Justificativa dos alunos para a } \\
\text { solução }\end{array}$ & $\begin{array}{l}\text { "Eu fiz da mesma maneira que a Cristina: } 1+1 \text { e } 2+2 \text { " ou a de António } \\
\text { para o cálculo de } 1 / 3+1 / 6 . \text { Eu pensei assim, já que são os dois com o } \\
\text { mesmo numerador eu posso somar e dá 1/9". }\end{array}$ \\
\hline $\begin{array}{c}\text { Evidência: Análise das estratégias } \\
\text { dos alunos }\end{array}$ & $\begin{array}{c}\text { "Dificuldades na compreensão do conceito de fração, influenciando a } \\
\text { forma como os alunos operam na ausência de contexto da realidade". }\end{array}$ \\
\hline $\begin{array}{c}\text { Ajustes nas tarefas a partir da } \\
\text { análise das estratégias }\end{array}$ & $\begin{array}{l}\text { "Apresentar situações contextualizadas"; "influenciar positivamente a } \\
\text { compreensão de representaçôes simbólicas e seu significado } \\
\text { apresentadas no cálculo das expressões": } \\
\text { "a) A mãe da Catarina fez um bolo de chocolate. Ao almoço a Catarina } \\
\text { comeu 1/10 e o pai 1/5. Ambos comeram mais ou menos de metade do } \\
\text { bolo de chocolate?" }\end{array}$ \\
\hline $\begin{array}{c}\text { Análise decorrente da gestão da } \\
\text { discussão em sala de aula }\end{array}$ & $\begin{array}{l}\text { "..é através da discussão das estratégias dos alunos que percebemos a } \\
\text { adequação das tarefas... }\end{array}$ \\
\hline
\end{tabular}

A dificuldade relacionada à soma de frações, identificada no recorte realizado do estudo destes autores, também merece especial atenção no documento do Ministério da Educação de Buenos Aires e que se

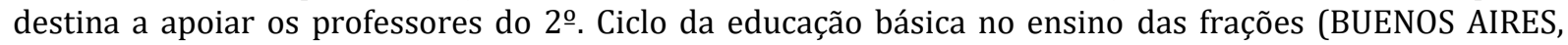
2001). No orientador, resultado de ações de capacitação de professores para a produção coletiva de propostas de ensino desenhadas para oportunizar a reflexão sobre as práticas atuais acerca do ensino das frações no sentido de incorporar novas formas de ensinar, são apontadas algumas "dificuldades dos alunos na aquisição das frações" (p.15).

Neste referencial é possível verificar que erros semelhantes aos identificados por Carvalho e Ponte também merecem destaque em suas análises. Os exemplos dos erros relatados no documento que orienta o ensino das frações, e as respectivas análises realizadas são apresentados no Quadro 2, a seguir:

\begin{tabular}{|c|l|}
\hline Exemplo 1: & Ao comparar frações os alunos respondem que: \\
& $1 / 3<1 / 5$ \\
& $1 / 5$ é a metade de $1 / 10$ \\
\hline \multirow{3}{*}{ Exemplo 2: } & Ao calcular: \\
& $2 / 3+4 / 5$ \\
& encontram $6 / 8$ \\
\hline \multirow{3}{*}{ Justificativa dos alunos } & "Como os numeradores são iguais e 3 é menor do que 5 então $1 / 3$ é \\
& menor do que 1/5"; "Os numeradores são iguais e 5 é a metade de \\
& 10 "; " \\
\hline Análise dos erros com base nas & "Transportam as propriedades do conjunto dos números naturais \\
& ao campo numérico dos números racionais, sem levar em conta \\
& que as frações formam um conjunto de números com propriedades \\
& especificas, distintas das propriedades dos números naturais"; \\
& "Somam os numeradores entre si e os denominadores entre si \\
& porque generalizam as propriedades da adição de números \\
& naturais no campo dos números racionais". \\
\hline
\end{tabular}

Saiz (1990) ao referir-se à mesma dificuldade a respeito da aquisição do conceito de fração, apontada por Carvalho e Pontes (2016) e exemplificada no Quadro 1, diz ser de um processo "lento e espiralado". Alerta ainda para a necessidade de que os estudantes desenvolvam uma compreensão operatória que pressupõe experiências que antecedem reconhecer que: (i) há uma regra para somar frações de denominadores iguais e outra para diferentes denominadores; (ii) há várias regras para comparar frações; (iii) há regras para fazer a conversão de uma fração em um número decimal, etc.

Godino (2004) também se detém na análise deste mesmo erro considerado comum aos alunos e apresentado no exemplo $1,[1 / 2<1 / 3]$. Este autor detém-se no significado do erro e na argumentação apresentada pelos alunos de que "2 é menor do que 3", apontando para o conhecimento dos números naturais como sendo talvez um obstáculo para a aprendizagem dos números racionais à medida que o erro se caracteriza pela extensão das propriedades dos primeiros e estes últimos. 
Já os Parâmetros Curriculares Nacionais (Brasil, 1997, p.101) referem-se ao raciocínio dos alunos, em torno das frações, como se fossem Números Naturais o que, assim como Godino (2004), Campos; Silva; Pietropaolo (2009) consideram essa relação da simples transferência das propriedades ou características, de um tipo de número para outro, como um obstáculo à aprendizagem.

Campos; Silva; Pietropaolo (2009) reconhecem que as propriedades das frações devem aparecer em contextos variados de modo a proporcionar aos estudantes as mesmas atividades que realizam com os números naturais, que definem como somar, dividir e ordenar.

Llinhares e Sánches (1988) apud Monteiro e Groenwald (2014) acrescentam a esse mesmo obstáculo o fato de que os símbolos dos Números Naturais também são utilizados para as frações, diferenciando-se apenas no traço na horizontal. Segundo eles, a experiência com os Números Naturais faz com os estudantes vejam as frações como um conjunto de dois Números Naturais separados por um traço e a utilização dos conhecimentos de cálculo, regras e algoritmos destes números para as frações.

No entanto, se analisarmos o processo de aprendizado do Sistema de Numeração decimal (SND) é possível perceber, como identificado nos estudos desenvolvidos por Zunino (1995), Mandarino e Belfort (2006), entre outros, que as crianças embora desconhecendo o valor posicional dos algarismos escrevem o número corretamente. Por exemplo, uma criança pode escrever corretamente o número "14" e, no entanto, não compreender que o algarismo " 1 " é utilizado nessa representação com um significado diferente do que ele assume em representações como "1" ou "21". Estas autoras analisam o fato de um mesmo símbolo poder representar quantidades diferentes como uma grande vantagem do sistema posicional e não como um impedimento para o aprendizado dos estudantes. Segundo elas, esta característica do sistema necessita ser explorada com auxílio de diferentes materiais e situações por tratar-se de um processo longo e que necessita da intervenção constante do professor.

Ao comparar o processor de aprendizagem do número, mais especificamente, do valor posicional, identificamos representações semelhantes ao que ocorre no aprendizado das frações, citado por Llinhares e Sánches (1988) ao afirmarem que os estudantes identificam a fração como "dois números" separados por "um traço".

Estas reflexões nos mostram que, assim como ocorre no aprendizado do SND, os estudantes não reconhecem a fração como um número mas, como símbolos isolados.

Nesta direção, Liao (2005), em sua pesquisa de mestrado, apresenta um aspecto relevante na compreensão da dificuldade dos estudantes da escola básica no estudo dos racionais ao se referir aos "signos" (símbolos numéricos), que originalmente surgem para representar um conjunto de contagem e que mais tarde é denominado conjunto dos racionais. Este conjunto tem conceitos próprios e intrínsecos aos alunos no entanto, pela escassez de outros signos matemáticos e a preocupação em tornar aquela linguagem excessivamente simbólica, cria-se uma possibilidade de combinação entre esses signos, que leva a novos conjuntos mas, com outros conceitos. Além do mais, cada um destes conjuntos numéricos, embora utilizando os mesmos signos, têm propriedades e operações diversas entre si.

Para Liao, o obstáculo no aprendizado das frações, tem forte relação com a "sequência didática" adotada na escolarização brasileira. 0 modo de fazer a leitura "desses signos" transporta o estudante para a conceituação de número natural e as suas respectivas propriedades. Adverte ainda que, a dificuldade e o não entendimento dos alunos deve-se à mudança dos significados numa combinação de signos, como por exemplo, os signos 2 e 3 , que representam quantidades naturais, e $2 / 3$, que representa uma quantidade completamente diferente das duas primeiras e sendo, inclusive, menor que 1.

Um outro aspecto relevante para esta revisão diz respeito aos diferentes significados que estão relacionados à ideia de fração. 0 que se observa é que tradicionalmente, nas situações escolarizadas, a fração é apresentada aos estudantes como "parte de um todo", desconsiderando as demais formas de interpretar esse número.

Sobre este mesmo aspecto, Belfort; Vasconcelos (2006) ressaltam que, ao contrário do que se pensa, assim como nas operações fundamentais as frações também estão associadas a mais de uma ideia. Para os autores, esta mesma redução que ocorre em relação ao significado das frações também acontece com muitos outros temas da matemática cujo ensino fica restrito, em geral, à aplicação de fórmulas e regras, sem que os alunos compreendam o que estão realizando. 
O Quadro 3, a seguir, organiza o que Belfort e Vasconcelos consideram necessário para o reconhecimento da fração e como esse número representa várias ideias diferentes.

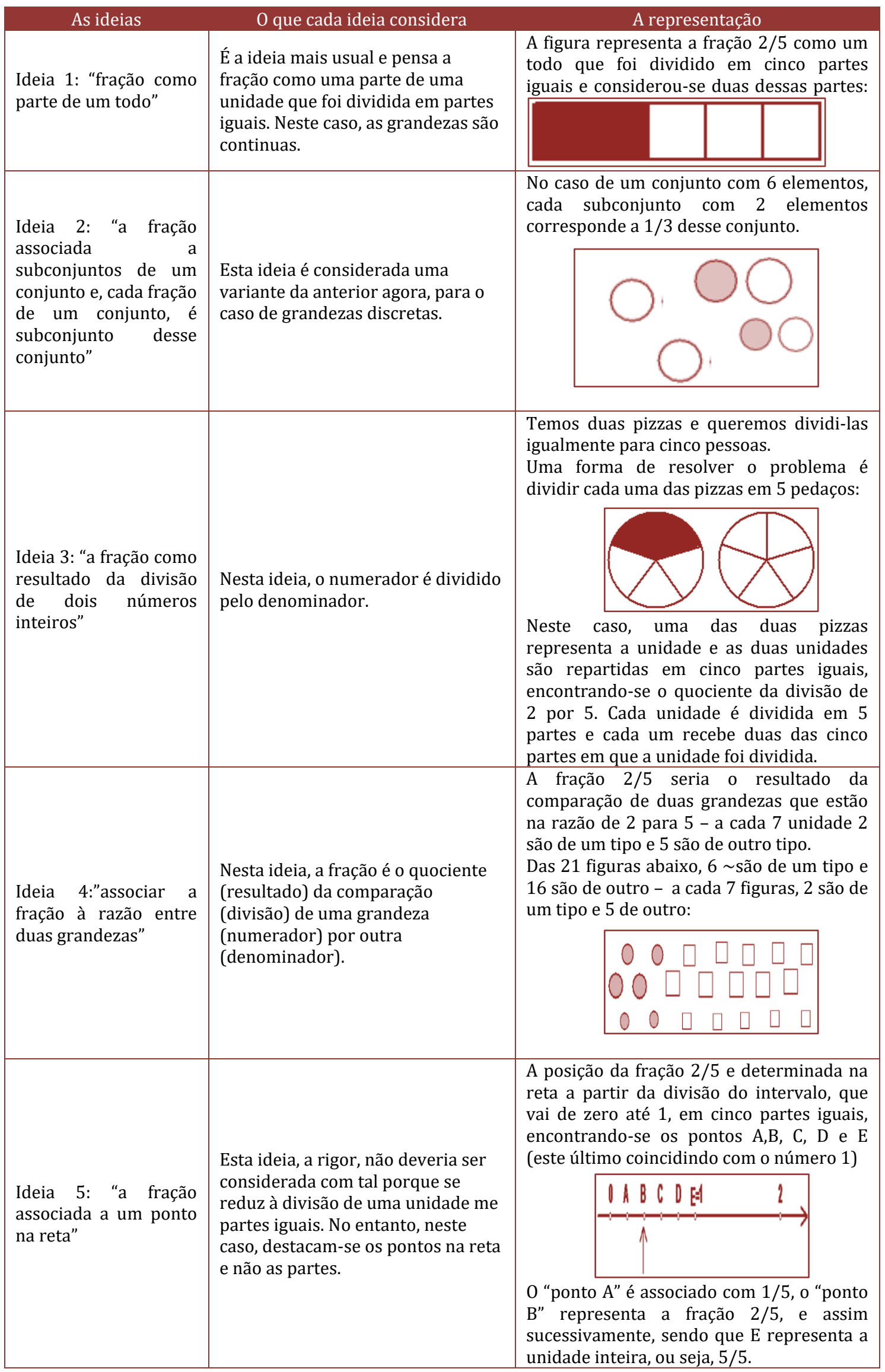


Nos estudos também desenvolvidos a respeito dos diferentes significados das frações, Dickson, Gibson \& Brown (1991) apontam para algumas destas mesmas interpretações apresentadas por Belfort e Vasconcellos como: (i) parte todo; (ii) subconjunto de um conjunto de objetos discretos; (iii) pontos de uma reta numérica; (iv) resultado de uma operação de divisão e (v) como medida. No entanto, estes afirmam que os erros dos estudantes geralmente vem associados à dificuldade de aprendizagem dessa grande quantidade de significados que as frações apresentam.

Para Nunes; Bryant (1997, p. 191), os estudantes, de maneira geral, parecem ter uma compreensão completa das frações mas que ainda não possuem. Esta suposta compreensão, segundo os autores, está aparentemente encoberta pelo fato de utilizarem os termos corretamente, falarem corretamente sobre elas e até resolverem alguns problemas. No entanto, aspectos conceituais passam despercebidos o que faz com que dificuldades deixem de ser superadas ou até identificadas pelos alunos e professores.

As pesquisas desenvolvidas por Nunes e Bryant a respeito do raciocínio das crianças sobre frações mostram que ao privilegiar o significado de parte-todo pode conduzir os estudantes ao erro porque compromete a compreensão de que o conjunto dos números racionais é uma extensão do conjunto dos números naturais. Além disso, afirmam haver uma discrepância dos estudantes entre a compreensão de divisão e números racionais fora da escola e o conhecimento de representações ensinadas na escola, por conta do modo como a linguagem fracionária é introduzida - "como um procedimento simples de contagem dupla em situações estáticas de parte-todo (NUNES; BRIANT(1997).

Estes autores enfatizam ainda que se os alunos resolvem problemas usando o conhecimento cotidiano que possuem e representações simbólicas, fazem conexões adequadas espontaneamente e utilizam o conhecimento cotidiano que possuem para resolver problemas mais complexos.

Já a pesquisa desenvolvida por Vasconcelos (2007), tendo como cenário as suas aulas de matemática na Educação Básica, constata um alto índice de dificuldades nos alunos na compreensão do conceito do número racional e mostra a necessidade de que estes tenham tempo para integrar os diferentes significados desse número, com seus símbolos e suas representações, o que o pesquisador considera como um ensino efetivo e uma aprendizagem significativa, pois reverte, assim, o quadro de dificuldades no ensino dos números fracionários.

\section{CONSIDERAÇÕES SOBRE OS ESTUDOS}

Os estudos de Nunes; Bryant contribuem para a necessidade de uma reflexão mais apurada quanto ao porquê dos estudantes pensarem as frações do modo como o fazem e o que os leva a realizar procedimentos que, embora reconhecendo os termos de uma fração ou mesmo os procedimentos operatórios não desenvolvem autonomia para a compreensão desses números.

Ao nos reportarmos aos estudos de Liao e à suposta compreensão das frações apontada por Nunes; Bryant é possível inferir que esta transposição conceitual de um conjunto para o outro parece ser desconsiderada no âmbito do ensino e no significado que é atribuído aos signos. 0 que, de certo modo, também ocorre no conjunto dos naturais quando as crianças se deparam com o Sistema de Numeração Decimal e o significado que necessitam atribuir aos símbolos (signos), para reconhecer o valor posicional dos mesmos.

Podemos ainda verificar pelas considerações a respeito do modo de ensinar o conjunto dos naturais e dos racionais que, mesmo os estudantes possuindo total domínio do conjunto dos naturais e das suas propriedades, no ensino dos racionais são desconsiderados aspectos relevantes que contribuiriam para realizar a chamada "transposição" de um conjunto para o outro.

No exemplo apresentado por Liao para os signos 2 e 3, no conjunto dos naturais e $2 / 3$ no conjunto dos racionais, o autor considera os $2 / 3$ como representação de uma quantidade menor do que 1 . No entanto, entendemos que esse reconhecimento não é preocupação quando nos deparamos com as sequências didáticas que abordam o ensino desses números. Esta hipótese é sustentada pelas constatações nos estudos de Nunes; Bryant, em que os estudantes reconhecem os termos de uma fração mas não a identificam como um número. E também, em Llinhares e Sánches quando se reportam ao fato de que os estudantes identificam a fração como "dois números" separados por "um traço".

Os obstáculos que são estudados pelos diversos autores, nos mostram que estas dificuldade estão, de modo geral, situadas na transposição de um conjunto para o outro. No entanto, o que podemos também observar a partir das nossas inferências sobre estes estudos é que as dificuldades que os estudantes apresentam na compreensão do conjunto dos racionais não estão situadas apenas na transposição mas na ausência da identificação por eles da fração como um número. E, pelo que relatamos, esta dificuldade 
também está presente no conjunto dos naturais, o que nos leva a crer que os obstáculos têm início bem antes da criança deparar-se com a fração.

$\mathrm{Na}$ análise dos PCN e estudos de Godino é recorrente a relação que os alunos estabelecem entre os naturais e os racionais como sendo um obstáculo à compreensão desses números. No entanto, considerar os conhecimentos que os estudantes já possuem sobre os números naturais como um obstáculo ao aprendizado dos racionais parece-nos negar a estes a estudantes, influenciados pelo que já sabem, a possibilidade de reconhecerem a capacidade que têm para ampliar esse conjunto e reconhecer as suas propriedades. Se esta capacidade dos alunos for desconsiderada também negamos o que se diz a respeito dos conhecimentos prévios e anteriores dos estudantes. Weisz (2002) diz que estes conhecimentos são a "base de novas aprendizagens - o que não significa a crença ou a defesa de pré-requisitos, ou tampouco a matéria ensinada anteriormente pelo professor". Além disso, deixa de ser desconsiderado também o que é defendido por Ausubel, et al. (1980, p.23), quando afirma que a aprendizagem matemática é uma construção pessoal e ativa do educando, exigindo que as novas informações se inter-relacionem com os demais conhecimentos existentes.

Vale ressaltar que, embora nos estudos revistos o contexto para a análise da dificuldade dos alunos tenha como foco os erros por eles cometidos, apenas Del Olmo (2015, p.6) faz referência ao significado do erro como "parte do processo da aprendizagem individual" apontando como base para essa referência os trabalhos de Karl Popper (1979), Gaston Bachelard (1978, 1988) e Imre Lakatos (1978).

Assim, o conceito de fração vai além de saber enunciar os termos corretamente porque depende de como se compreende cada um dos seus significados nas múltiplas interpretações que esse número admite.

Por outro lado, parece-nos que não podemos desconsiderar o fato de que aquilo que os estudantes apreendem não depende apenas da forma como se ensina mas também, em igual medida, do que é influenciado pelo que já sabem, incluindo nisto as crenças que possuem sobre a matemática.

Os trabalhos de Belfort e Vasconcellos também ressaltam a questão do modo de ensinar as frações que, além de reduzir esse número a uma única ideia (parte todo) o seu uso fica restrito à aplicação em cálculos orientados por regras que devem ser memorizadas sem que os estudantes tenham a compreensão do fazem.

Podemos também perceber, no caso da redução do ensino da fração a uma única de suas ideias, como prática recorrente no modo de ensinar esse número, que também está presente nos exemplos utilizados nas pesquisas os quais centram a análise das dificuldades dos alunos nesse único modelo.

Ao analisarmos o Quadro 3 que apresenta as diferentes ideias da fração, a "Ideia 1: parte-todo", e que é a mais usualmente ensinada, relaciona a fração com a "área" da figura, ou seja, a superfície que representa o objeto. Assim, cada parte pintada do retângulo representa $1 / 5$ da área do retângulo e cada uma dessas cinco partes têm a mesma área.

Estas noções, como a de "parte de um todo", as crianças já trazem de sua vida social em função de situações de partição de bolos, pães e chocolate. No entanto esta ideia necessita ser aprimorada na escola porque estes conhecimentos prévios vem associados a distorções conceituais que acabam por incorporarse ao aprendizado dos estudantes acompanhando-os por toda a trajetória escolar. Por exemplo, é muito comum crianças dizerem que querem a "metade maior", o que evidencia que, embora elas enunciem a fração como parte de um todo, não consideram que a divisão é em "partes iguais" e que o conceito ainda não está construído.

No caso dos estudos voltados para os diferentes significados das frações, como os de Belfort; Vasconcellos e Dickson, Gibson \& Brown mostram divergências quanto ao que leva o estudante ao erro ou a falta de compreensão nas frações. Enquanto Belfort e Vasconcellos ressaltam como obstáculos ao aprendizado das frações o modo de ensinar traduzido na redução desse número a uma única ideia, o seu uso restrito às contas com base em regras memorizadas e sem que os estudantes compreendam o que fazem, Dickson, Gibson \& Brown afirmam que é essa grande quantidade de significados que, geralmente, provoca os erros nos estudantes.

No entanto, é fato que esses vários significados estão longe de ser estudados pelos estudantes, como é apontado por Belfort e Vanconcellos ao sustentarem que o modo de ensinar as frações é reduzido unicamente à ideia de parte- todo. Além destes autores, Liao, em sua pesquisa, observa que ao analisar diferentes livros didáticos (4ํ․ e 5‥ anos) as frações são apresentadas como representações apenas de modelos contínuos e, mais que isso, as frações não são apresentadas como um outro conjunto numérico ou a exploração das propriedades elementares do conjunto dos racionais. 
Assim, se os estudantes desconhecem as diferentes ideias ou significados das frações, e as suas experiências escolares com esse número são reduzidas apenas a modelos contínuos, como estas podem provocar erros nos estudantes? Não seria a ausência delas?

Além disso, se as frações não são apresentadas aos estudantes como um conjunto numérico com as suas respectivas propriedades, como então eles podem mostrar dificuldades na transposição de um conjunto (naturais) para outro (racionais), se este último não é identificado por eles?

\subsection{QUE OS EXAMES EM LARGA ESCALA CONSIDERAM SOBRE AS FRAÇÕES}

Para melhor compreender o que é selecionado para o ensino das frações na escola básica partimos do pressuposto que a análise dos descritores e questões dos exames em larga pode contribuir para identificar o que se considera em relação a essa proficiência. Isto porque, de acordo com a Nota Técnica do Instituto Nacional de Estudos e Pesquisa (INEP, 2010), o desempenho dos estudantes nestes exames são informações que, quando associadas às do rendimento escolar, determinam o indicador de qualidade educacional (IDEB).

É também importante considerar ainda que a proficiência em Matemática (MACHADO, 2001) não está vinculada exclusivamente ao que se sabe de Matemática mas com o que se é capaz de fazer com ela. Nesse sentido, é necessário identificar o conhecimento do conteúdo matemático e a capacidade de criar estratégias na resolução de problemas.

A pesquisa de mestrado realizada por Vaccaro (2010) desenvolveu estudo nessa direção, analisando as diretrizes da Prova Brasil, os descritores que orientam os itens da prova que abordam as frações e as questões associadas a elas.

No levantamento feito pelo autor, de acordo com a Nota Técnica do Instituto Nacional de Estudos e Pesquisa (INEP, 2010), o desempenho dos estudantes nos exames padronizados, como a Prova Brasil, por exemplo, são dados que associados às do rendimento escolar (aprovação) determinam o indicador de qualidade educacional (IDEB). Este indicador, segundo o INEP, foi desenvolvido para sintetizar informações de desempenho em exames padronizados com informações sobre rendimento escolar (taxa média de aprovação dos estudantes na etapa de ensino).

No entanto, Vaccaro adverte que é uma afirmação imediata e descuidada dizer que as avaliações em larga escala medem a proficiência matemática dos avaliados justificando que qualquer avaliação priorizará apenas alguns aspectos dos conteúdos matemáticos e que são definidos pelos grupos envolvidos nas avaliações, e que atendam ao modelo das questões. E este mesmo autor identifica interesses conflitantes entre o que estes grupos interessados nas avaliações priorizam. Com base no que Schoenfeld (2007) apresenta a respeito desses interesse, Vaccaro mostra que para os Matemáticos, as avaliações de Matemática devem ser direcionadas a respeito das ideias centrais da Matemática. Já para os pesquisadores em Educação Matemática, estas mesmas avaliações devem refletir o "pensamento matemático" (thinking mathematically), que segundo Schoenfeld (2007, p.5) in Vaccaro (2007), se caracteriza pelo conhecimento conceitual - compreensão dos conceitos matemáticos, operações e relações; pela fluência procedimental capacidade de realizar procedimentos, flexíveis, precisos, eficientes e apropriados; raciocínio adaptativo capacidade de pensar logicamente, refletir, explicar e justificar; e disposição produtiva - inclinação habitual para perceber a matemática como algo compreensível, útil e valorosa, conectada com zelo e a eficácia. Do ponto de vista dos pais, a função das avaliações de matemática é esclarecer a respeito do conhecimento e progresso dos filhos - informar o que os filhos fazem "bem" e o que fazem "mal" para que possam providenciar o apoio necessário. As avaliações de Matemática na perspectiva dos professores devem ajudar tanto a eles próprios quanto aos estudantes a identificar as áreas nas quais ambos necessitam desenvolver-se. Para o grupo dos administradores (supervisores, gestores, secretários de educação, legisladores, prefeitos, governadores e o próprio presidente) o principal objetivo das avaliações é prover indicadores que permitam identificar qual é o estado do sistema educacional nos respectivos níveis de atuação de cada um deles. No caso do grupo de elabores, e são estes que definem o design e conteúdo das avaliações, devem conseguir satisfazer, além dos seus próprios interesses, os daqueles que os contratam e, na medida do possível, os interesses dos demais grupos. Como podemos observar, este grupo dos elaboradores, define as avaliações mediante a presença de fatores de pressão, entre eles, o do custo porque espera-se que, de modo geral, que o custo das avaliações aplicadas um grande número de participantes seja baixo. De acordo com Schoenfeld essa é uma das razões para o uso das questões de múltipla escolha. 
Além disso, as pressões exercidas pela determinação dos critérios técnicos utilizados nos exames de larga escala em Matemática, os chamados critérios psicosométricos acabam por se sobrepor aos conteúdos matemáticos destes mesmos testes. Esta sobreposição é determinante para provocar o embate entre a relevância que é atribuída aos critérios psicométricos e as informações que efetivamente poderiam auxiliar o professor nas ações pedagógicas.

Vale ressaltar um aspecto apontado por Burkhardt (2007, p. 78 e 79) in Vaccaro (2007) que diz respeito à influência que as avaliações exercem no sistema educacional. Embora não sendo apenas negativas, estas avaliações apresentam limitações e a crença de que sejam instrumentos precisos e capazes de abordar tudo o que se considera importante em Matemática relativo a um determinado conteúdo.

Deste modo, a proficiência em Matemática que estas avaliações declaram avaliar assume significado diferente daquele que considerado por Machado (2001) e que pressupõe a identificação do conhecimento do conteúdo matemático e a capacidade de criar estratégias na resolução de problemas.

Embora a Matriz de Referência de Matemática (INEP,2010), que apresenta os princípios da Prova Brasil, admita que está estruturada sobre o "foco da resolução de problemas", os itens propõe apenas a solução pelo estudante do problema, enquanto que a formulação do modelo já é apresentada pronta. Deste modo, o modelo e design do exame, não permite observar as etapas de solução do problema pelo estudante.

Por outro lado, para justificar essa incompletude esse mesmo documento afirma que "um aluno é capaz de resolver um problema a partir da utilização/aplicação de um conceito por ele já construído".

Esta justificativa reafirma a limitação dos itens da prova para avaliar estratégias de resolução. No entanto é o reconhecimento destas estratégias que nos irá fornecer as pistas em relação a proficiência do estudante.

\section{AS FRAÇÕES NOS ITENS DA PROVA BRASIL}

Para analisar como as frações são abordadas nos itens da Prova Brasile, apresentamos um recorte do estudo realizado por Vaccaro (2007) cujo o foco são itens que apresentam o conteúdo das frações. Os itens selecionados exemplificam descritores referentes ao 9o ano do ensino fundamental e fazem parte da publicação do Ministério da Educação (MEC) distribuída às escolas com o título de PDE/Prova Brasil e cujo objetivo maior, proposto no documento, é de "envolver gestores, docentes e demais profissionais da área da educação" no "conhecimento desse instrumento cognitivo de avaliação e sua importância para o alcance das metas propostas pelo Ideb".

A organização do Quadro 4, a seguir, procura favorecer a identificação do raciocínio utilizado na análise que fizemos do documento. Para isso, consideramos os itens que abordam as frações, "descritor" e a "habilidade" a ser avaliada para, então, relacioná-los às orientações que são propostas aos professores, no mesmo documento.

Análise dos itens e das suas respectivas orientações para o professor:

Entendemos que a análise das "sugestões para melhorar a habilidade avaliada" que são apresentadas para cada um dos itens da prova pode declarar o desejável em relação ao aprendizado das frações. Além disso, por tratar-se de um documento distribuído nas escolas e direcionado ao professor, fica mais evidente a intencionalidade de orientar a ação docente.

Descritor 21 - para este descritor o documento sugere ao professor atividades que podem melhorar esta habilidade e que se caracterizam por propor aos estudantes que "a partir dos números racionais na forma fracionária efetuem a divisão do numerador pelo denominador, obtendo-se o correspondente decimal.

\footnotetext{
${ }^{8}$ A Prova Brasil e o Sistema Nacional de Avaliação da Educação Básica (Saeb) são avaliações para diagnóstico, em larga escala, desenvolvidas pelo Instituto Nacional de Estudos e Pesquisas Educacionais Anísio Teixeira (Inep/MEC). Disponível em: http://portal.mec.gov.br/prova-brasil
} 


\begin{tabular}{|c|c|c|c|c|c|}
\hline $\begin{array}{l}\text { 1.Análise dos itens e das } \\
\text { suas respectivas } \\
\text { orientações para o } \\
\text { professor:Descritor }\end{array}$ & Habilidade & \multicolumn{4}{|c|}{ Item/Percentual de respostas às alterbativas } \\
\hline \multirow{3}{*}{$\begin{array}{l}\text { Descritor } 21 \text { - Reconhecer } \\
\text { diferentes representações } \\
\text { de um número racional. }\end{array}$} & \multirow{3}{*}{$\begin{array}{l}\text { "de o aluno identificar } \\
\text { números racionais nas } \\
\text { suas diversas } \\
\text { representações: } \\
\text { fracionária, decimal ou } \\
\text { percentual". }\end{array}$} & \multicolumn{4}{|c|}{$\begin{array}{c}\text { No Brasil,3/4 } \\
\text { da população vive na zona urbana. } \\
\text { De que outra forma podemos representar esta } \\
\text { fração? } \\
\text { (A) } 15 \% \text {. (B) } 25 \% \text {. (C) } 34 \% \text {. (D) } 75 \% \text {. }\end{array}$} \\
\hline & & A & B & c & D \\
\hline & & $16 \%$ & $17 \%$ & $32 \%$ & $32 \%$ \\
\hline \multirow{3}{*}{$\begin{array}{l}\text { Descritor } 22 \text { - Identificar } \\
\text { fração como representação } \\
\text { que pode estar associada a } \\
\text { diferentes significados }\end{array}$} & \multirow{3}{*}{$\begin{array}{l}\text { "de o aluno reconhecer } \\
\text { frações em diversas } \\
\text { representações como, } \\
\text { por exemplo, partes de } \\
\text { um inteiro, relação entre } \\
\text { conjuntos, razão entre } \\
\text { medidas } \\
\text { etc". }\end{array}$} & \multicolumn{4}{|c|}{$\begin{array}{l}\text { Dos } 11 \text { jogadores de um time de futebol, apenas } \\
5 \text { têm menos de } 25 \text { anos de idade. } \\
\text { A fração de jogadores desse time, com menos de } \\
25 \text { anos de idade, é } \\
\begin{array}{llll}\text { (A) } \quad 5 / 6 & \text { (B) } 6 / 5 & \text { (C) } 5 / 11 & \text { (D) } 6 / 11\end{array}\end{array}$} \\
\hline & & A & B & $c$ & D \\
\hline & & $19 \%$ & $14 \%$ & $58 \%$ & $8 \%$ \\
\hline \multirow[t]{3}{*}{$\begin{array}{l}\text { Descritor } 23 \text { - Identificar } \\
\text { frações equivalentes }\end{array}$} & \multirow[t]{3}{*}{$\begin{array}{l}\text { "de o aluno reconhecer } \\
\text { que uma fração também } \\
\text { pode ser representada } \\
\text { por um conjunto infinito } \\
\text { de outras frações } \\
\text { equivalentes a ela". }\end{array}$} & \multicolumn{4}{|c|}{$\begin{array}{l}\text { Quatro amigos, João, Pedro, Ana e Maria, saíram } \\
\text { juntos para fazer um passeio por um mesmo } \\
\text { caminho. Até agora, João andou 6/8 do caminho; } \\
\text { Pedro, 9/12; Ana. 3/8 e Maria, 4/6. Os amigos } \\
\text { que se encontram no mesmo ponto do caminho } \\
\text { são } \\
\text { (A) João e Pedro; (B) João e Maria } \\
\text { (B) Ana e Maria; (D) Pedro e Ana }\end{array}$} \\
\hline & & A & B & c & D \\
\hline & & $26 \%$ & $41 \%$ & $19 \%$ & $\mathbf{9} \%$ \\
\hline
\end{tabular}

Com base na revisão dos estudos anteriormente apresentada, as afirmações de Belfort e Vasconcellos nos permitem declarar que atividades do tipo como a sugerida pelo documento ao professor para desenvolver a habilidade avaliada pelo item com os seus alunos, reforçam a ideia do ensino de fração restrito à aplicação de cálculos (efetuar a divisão), orientado por regras (dividir o numerador pelo denominador), que devem ser memorizadas. E ainda, de acordo com estes autores, este tipo de procedimento permite que os estudantes até realizem as operações mas, sem ter a compreensão do que fazem. Sob este mesmo ponto de vista, Nunes e Bryant afirmam que esta suposta compreensão, e agora tomando como referência os "acertos" apresentados pelo item, faz com que os aspectos conceituais passem despercebidos e as dificuldades identificadas pelos professores.

Deste modo, ao propor que os alunos realizem cálculos e "reforcem" a aplicação da regra, como a sugestão apresentada no documento para "melhor desenvolver a habilidade" que é avaliada pelo item, estamos desconsiderando a necessidade que para "reconhecer as regras de conversão de uma fração em decimal, antecede a necessidade dos estudantes desenvolverem experiências que lhes permitam a compreensão operatória. A sugestão proposta, esconde a origem do problema, que é conceitual, e reafirma, cada vez mais, o desenvolvimento da habilidade de "responder corretamente" ao item.

Descritor 22 - para este descritor o documento sugere ao professor que sejam dadas diversas atividades nas quais os alunos devem representar frações utilizando materiais concretos e, posteriormente, escrever as frações correspondentes às situações-problema propostas.

Embora a proposta da manipulação de materiais seja uma estratégia que pode contribuir para a compreensão da fração associada a subconjuntos de um conjunto e, cada fração de um conjunto, como subconjunto desse conjunto (BELFORT; VASCONCELLOS, 2006), esta ideia de fração, para o caso de grandezas discretas, é considerada uma variante da ideia parte-todo. Desse modo, as orientações ao professor com base em atividades semelhantes à proposta neste item ratificam o que já foi identificado por Nunes e Bryant na crítica que fazem à forte tendência de privilegiar o significado de parte-todo no 
trabalho com as frações e como a compreensão de que o conjunto dos números racionais é uma extensão do conjunto dos números naturais fica prejudicada se o método escolhido focar somente este significado. Neste mesmo modo de entender, os estudos de Belfort e Vasconcellos também asseguram que ao reduzir as frações a uma única ideia (parte-todo) o uso desse número fica restrito à aplicação de cálculos orientados por regras.

Vale ressaltar que o documento, com base no índice de acertos dos alunos, afirma que 58\% deles dominam a habilidade de reconhecer frações em diversas representações. No entanto, a afirmação reduz as demais ideias a uma única e àquela que é mais usual, ou a preferível quando nos deparamos com o ensino e a avaliação do aprendizado das frações. Esta redução, porém, deixa de ser perceptível ou considerada na afirmação de que $58 \%$ dos alunos dominam a habilidade com as ideias de "partes de um inteiro, relação entre conjuntos, razão entre medidas etc", supondo que ao dominar uma ideia o aluno também domina as demais. O que nos leva a concluir que, embora o descritor mencione as diferentes ideias das frações, estas são consideradas como apenas uma.

Descritor 23 - 0 documento analisa o que "sugere o resultado" de $41 \%$ dos alunos assinalarem a alternativa incorreta (B), classificando-o como "sintomático" e, possivelmente, devido à igualdade entre os denominadores das frações, concluindo que apenas um quarto do universo avaliado mostrou dominar a habilidade do alunos reconhecer que uma fração também pode ser representada por um conjunto infinito de outras frações equivalentes a ela.

A revisão dos estudos de Carvalho e Ponte mostra que os alunos justificam os procedimentos com denominadores iguais, e que caracterizam erros, como sendo estes denominadores um Número Natural e a fração como um conjunto de dois Números Naturais separados por um traço. No entanto, as propostas para desenvolver esta habilidade nos alunos, sugeridas aos professores no documento orientam para "exercitar a representação de frações equivalentes, por meio de simplificação de numeradores e denominadores". Constata-se assim, mais uma vez, o "reforço" de procedimentos mecanizados sobrepondo-se à compreensão da fração e os erros apresentados pelos alunos reconhecidos como dificuldades na transposição de um conjunto para outro, dos Naturais para os Racionais. Porém, como observado em análise anterior, as frações não são apresentadas como um conjunto numérico, desse modo, associar à dificuldade ou o erro do aluno a essa transposição, não se sustenta.

Nos detivemos na análise de itens que apresentam as frações no conjunto dos Racionais Positivos por tratarmos das dificuldades inicias que os alunos apresentam quando se deparam com as frações e que são trabalhadas no conjunto destes números.

Deste modo, a apresentação do diálogo entre diferentes autores e documentos orientadores do ensino da matemática, a partir dos pressupostos conceituais que adotam, podem tornar possível identificar as insuficiências presentes nas redes conceituais que sustentam escolhas metodológicas no ensino desses números e também, por que não, no que orienta a elaboração dos itens dos exames.

\subsection{QUE CONCLUÍMOS}

Considerando que o desempenho dos estudantes diretrizes dos exames em larga escala e respectivas questões desses exames quando verificamos os descritores que orientam a elaboração dos itens dos exames, neste caso da Prova Brasil de 2015, constamos que reforçam a ideia do ensino de fração restrito à aplicação de cálculos, orientados por regras que devem ser memorizadas.

A análise do estudo realizado por Vaccaro, mais especificamente em relação às características dos exames e das limitações que apresentam, nos permitem expor que a influência que estes exercem no ensino da matemática estão situadas: (a) nos critérios psicométricos utilizados nas avaliações em larga escala que se sobrepõem ao conteúdo matemático; (b) na tendência em focar fundamentalmente as habilidades em detrimento do entendimento conceitual e a resolução de problemas; (d) na adequação dos currículos aos conteúdos expressos nos itens dos exames e, desse modo, desconsiderando o que é relevante para o entendimento conceitual.

A adequação do conteúdo matemático aos itens dos exames caracteriza uma redução no que diferentes grupos dizem considerar como necessário para o aprendizado. No entanto, a relevância atribuída a esse instrumento de medida, as informações que são obtidas a partir dele determinam tomadas de decisão com respeito às ações referentes aos processos educativos. Além disso, direcionam a análise do professor para um conteúdo matemático que é reduzido ou até incompleto em detrimento das limitações dessas avaliações. 
Mais ainda, pela forte influência que estes exames exercem, determinam a escolha dos conteúdos a serem trabalhados pelos professores. Deste modo, os estudantes acabam tendo um estudo reduzido às mesmas abordagens que aparecem nas questões dos exames.

No caso das frações, a análise das questões mostra que, ao privilegiar aspectos como um único modelo de fração, parte-todo, desconsiderando as demais ideias, a valorização de regras e procedimentos de cálculo, provavelmente serão estes também os aspectos priorizados e trabalhados pelos professores.

Esta possibilidade é ratificada pelos demais estudos apresentados que apontam para os erros dos alunos no aprendizado desses números. Embora identifiquem como causas dos erros situações como a transposição conceitual de um conjunto para outro, a redução da abordagem da diferentes ideias das fração a uma única: parte-todo, entre outras, entendemos que as dificuldades antecedem a estas questões porque os estudantes não experimentam o aprendizado desses conteúdos. Esta afirmação se sustenta no fato de que, se os exames orientam e até determinam a extensão do conteúdo de fração e abordagem que é dada a ele. Aspectos como o significado da fração, o reconhecimento das frações em diversas representações (por exemplo, como a razão entre duas grandezas, associada a um ponto na reta), a resolução de problemas utilizando o conhecimento cotidiano e representações simbólicas deixam de ser considerados por essas avaliações em função do que foi exposto, quando da análise desses exames. Desse modo, a dificuldade dos alunos quando se deparam com as frações, advém do modo como é ensinado esse número e que parece ser determinado pelos exames.

Os estudos realizados em torno das dificuldades que os estudantes apresentam no aprendizado das frações quando comparados com o modo como este aprendizado é avaliado pelos exames em larga escala e o interesse dos grupo de elabores nas propriedades estatística dos itens e, considerando a influência que estes mesmos instrumentos exercem no ensino da Matemática e nas escolhas que os professores fazem em relação aos conteúdos que ensinam, é possível concluir que se considera para a proficiência dos estudantes no aprendizado das frações, o que é fácil de medir e não o que constitui o entendimento conceitual desse número.

Embora sabedores de que produzir uma avaliação não seja uma tarefa fácil e que os elaboradores devem satisfazer exigências diversas e por vezes contraditórias, como a relação de proficiência com as limitações que os itens dos exames impõem, esta quantidade reduzida de itens que mede o aprendizado das frações desconsidera aspectos importantes da proficiência matemática em relação às frações, considerando apenas alguns de seus componentes.

Esta redução feita nos componentes considerados pelos itens dos exames e que avaliam apenas uma das muitas ideias das frações e valorizam procedimentos de cálculo, traduz o que os estudos apontam como uma das causas mais recorrentes que contribui para a dificuldade dos alunos no aprendizado das frações.

Ao considerarmos a influência que os exames exercem na escolha dos conteúdos de matemática pelos professores e a abordagem dada a eles, podemos também concluir que os aspectos das frações avaliados nos exames passam a ser a referência do aprendizado desses números, desconsiderando aspectos relevantes como foram apontados no estudo desses números.

Além disso, a também dita proficiência matemática é determinada pelo que os exames consideram nos itens estabelecidos para os conteúdos matemáticos. No entanto, os itens desconsideram as etapas de solução de um problema cujo modelo é apresentado pronto, como já comentado anteriormente. Desse modo, são proficientes em frações aqueles estudantes que reconhecem a fração como parte todo e sabem operar com esses números.

Deste modo, o que se verifica para o aprendizado das frações é a eficácia do saber realizar procedimentos de cálculo e memorização de procedimentos em questões que, embora denominadas como problemas, apenas propõe a solução, enquanto que o modelo já é apresentado pronto desconsiderando qualquer possibilidade de avaliar estratégias de resolução.

Os discursos que sustentam as diretrizes das avaliações condensam e expõem o que se considera desejável ou preferível: a proficiência em matemática predominantemente associada a memorizações e procedimentos. Estes discursos situam o caráter seletivo da escolarização e cujo núcleo dessa representação é o cálculo. Se o ensino das frações é determinado pelos exames identificar o que os itens dos exames e suas diretrizes estabelecem como preferível para esse ensino pode situar a representação da disciplina de Matemática no ensino em nosso país.

A valorização dos conteúdos escolares que são passíveis de ser avaliados pelos exames subjuga a complexidade do processo de ensino e de aprendizagem em matemática. 
Temos, então, um sistema de ensino dependente de um outro que o avalia e que se diz capaz de mensurar as competências matemáticas dos estudantes. Por outro lado, não se pode deixar de considerar que a matemática escolarizada, supostamente orientada por essa dependência, reduz o desenvolvimento cognitivo dos estudantes nessa disciplina à realização de procedimentos de cálculo, memorização pura e simples como se este ensino tivesse como único propósito (necessidade) selecionar (reduzir) o que é requerido pela sociedade em geral - "passar nos exames".

Esta dependência entre qualidade de ensino e resultados de exames mostra que estes determinam e expressam o aproveitamento dos alunos contribuindo para reforçar uma postura do professor, que vem de longa data. Esta prática do professor não valoriza o esforço do estudante na resolução do problema e sim na aplicação de uma determinada conta.

E, embora o sistema de ensino de matemática, coordenado por um sistema de seleção, traduzido em exames, se diga eficaz, os alunos fracassam.

\section{REFERÊNCIAS}

[1] Ausubel, D. P.; Novak, J. D. \& Hanesian, H. Psicologia Educacional. Rio de Janeiro: Editora Interamericana, 1980.

[2] Brasil. Mec. Secretaria de Ensino Fundamental. Parâmetros Curriculares Nacionais de Matemática para o 1 o e 2o Ciclos. Brasília, DF: MEC/SEF, 1997.

[3] Brown, A. Design experiments: theoretical and methodological challenges in creating complex interventions in classroom settings. The Journal of the Learning Science, v.2, n.2, p.141-178, 1992.

[4] Belfort,E.S.M.; Vasconcelos, C. Discutindo Práticas em Matemática. Diferentes significados de um mesmo conceito: o caso das frações. Secretaria de Educação a Distância/MEC. Boletim 13, agosto/2016, p. 38-47.

[5] Buenos Aires. La enseñanza de las fracciones en el 2do ciclo de la Educación General Básica. Módulo 2, Serie Aportes al Proyecto Curricular Institucional Agosto 2001.

[6] Campos, T. M. de M.; Silva, A. F. G.; Pietropaolo, R. C. Considerações a respeito do ensino e aprendizagem de representações fracionárias de números Racionais. In: Guimarães, G.; B.; Rosa, R. E. S. (Org.). Reflexões Sobre 0 Ensino de Matemática nos Anos Iniciais de Escolarização. RECIFE: SBEM, 2009. Cap. 9, p. 131-139.

[7] Carvalho, R., Ponte, J.P. Desenvolver o cálculo mental: Construção de uma teoria local de aprendizagem através de uma Investigação Baseada em Design. Atas Provisórias do XXVII Sem. Investigação em Educação Matemática. Porto: APM, (2016), pp. 311-326.

[8] Collins, A. Towards a design science of education. In: E. Scanlon and T. O'Shea (eds), New directions in educational technology. Berlin: Springer, 1992.

[9] Del Olmo, D.G. Errores comunes en el aprendizage de las fraciones: Un estudio con alunmos de 12/13 años en Cantabria. Universidad de Cantabria. Facultad de Educación, 2015.Máster en formación del professorado de educación secundaria.

[10] Dickson, L. - Brown, M. - Gibson, O. El aprendizaje de las matemáticas. Labor / M.E.C. Madrid, 1991

[11] Godino, J. Didáctica de las matemáticas para maestros. Proyecto Edumat-Maestros. Granada, (2004). Disponível em: http://www.ugr.es/ jgodino/edumat-maestros/manual/9_didactica_maestros.pdf

[12] Inep. Índice de Desenvolvimento da Educação Básica (nota técnica), 2010. Disponível

[13] emhttp://portalideb.inep.gov.br/index.php?option=com_content\&task=view\&id=4\&Itemid=5

[14] Liao, T. Uma análise do uso de modelos computacionais no ensino de Frações. Cocpg/Cefet/RJ, M.P.E.C.M, Ensino de Ciências e Matemática, 2005 . Dissertação (Mestrado) Centro Federal de Educação Tecnológica Celso Suckow da Fonseca, 2005.

[15] Llinares, S. C.; Sánchez, M. V. G. Fracciones la relacion parte-todo. Madrid: Sintesis, 1988.

[16] Machado, N. J. Matemática e Língua materna: análise de uma impregnação mútua. São Paulo: Cortez, 2001.

[17] Mandarino, M.C.F.; Belfort, E.S.M. Números Naturais: conteúdo e Forma. Ministério da Educação, UFRJ/LIMC, 2005.

[18] Nunes, T.; Bryant, P. Crianças fazendo Matemática. Porto Alegre: Artes Médicas, 1997.

[19] Saíz I (1990): Fracciones. Un aprendizaje diferente. Revista Hacer Escuela. Año XII. No. 10. Setiembre. Pag. 28 a 31. Ed. Niño y Dávila. 
[20] Vasconcelos, I. C. P. Números fracionários: a construção dos diferentes significados por alunos de $4^{\underline{a}}$ a $8^{\underline{a}}$ séries de uma escola do ensino fundamental. 2007. 104f. Dissertação (Mestrado em Educação). Programa de Pósgraduação em Educação. Universidade Federal do Rio Grande do Sul. Porto Alegre, RS.

[21] Weisz, T. O diálogo entre o ensino e a aprendizagem. São Paulo Editora Ática, 2002.

[22] Zunino, D. L. de. A matemática na escola: aqui e agora. Trad. Juan Acuña Llorens. - 2.ed. - Porto Alegre: Artes Médicass, 1995. 


\section{Capítulo 7}

Uma análise acerca da produção de conjecturas e provas matemáticas de alunos do $8^{\circ}$ ano do ensino fundamental

\section{Liana Krakecker \\ José Luiz Magalhães de Freitas}

Resumo: 0 objetivo deste artigo é apresentar considerações e perspectivas advindas de um trabalho, cujo objetivo consistiu em analisar a produção de conjecturas e provas de propriedades envolvendo ângulos de polígonos, por alunos do $8^{\circ}$ ano do ensino fundamental. 0 percurso metodológico seguiu os princípios da Engenharia Didática e foi aplicada uma sequência de atividades em contraturno escolar e analisados dados dos alunos com maior frequência nos encontros. Observou-se que atividades experimentais e as diferentes formações das duplas, ao longo dos encontros, favoreceram a elaboração de conjecturas. Apesar da maioria das provas serem fundamentadas em manipulações ou experimentações com utilização do transferidor e evidenciarem dificuldades dos alunos no que concerne à escrita em linguagem matemática, foi possível constatar evoluções em relação à produção de argumentos de prova apresentados.

Palavras-chave: Conjecturas. Tipologia de Provas. Ângulos. Validação. 


\section{INTRODUÇÃO}

Os Parâmetros Curriculares Nacionais indicam que, desde os primeiros anos de escolaridade, devem ser exploradas metodologias que favoreçam a criação de estratégias, comprovação, justificativa, argumentação, espírito crítico, criatividade, trabalho coletivo, autonomia, dentre outros. (BRASIL, 1997). Uma das orientações contidas nesse documento, em relação aos anos finais do ensino fundamental, consiste no trabalho com investigações e a argumentação acerca da validade dos resultados e das conjecturas por meio da linguagem oral e das diversas representações matemáticas (BRASIL, 1998).

Ainda, conforme o nível de escolaridade aumenta, há a indicação para o trabalho com algumas provas de propriedades, pois é:

[...] desejável que no terceiro ciclo se trabalhe para desenvolver a argumentação, de modo que os alunos não se satisfaçam apenas com a produção de respostas a afirmações, mas assumam a atitude de sempre tentar justificá-las. Tendo por base esse trabalho, pode-se avançar no quarto ciclo para que o aluno reconheça a importância das demonstrações em Matemática, compreendendo provas de alguns teoremas. (BRASIL, p. 1988 70-71)

Mesmo diante de tais orientações, nem sempre os alunos têm contato com provas matemáticas em sala de aula, como observamos em Oliveira (2009), Mello (2009), Piccelli (2010), entre outros. Estas pesquisas, cujos enfoques voltaram-se mais para a produção de provas e demonstrações evidenciam, por um lado, lacunas em relação às validações matemáticas e, por outro, mostram que com um trabalho orientado é possível que alunos de ensino fundamental apresentem provas de propriedades mais elaboradas no decorrer do tempo.

Neste contexto, desenvolvemos um trabalho no qual tínhamos o objetivo de analisar a produção de conjecturas e provas relativas a ângulos de polígonos que alunos de $8^{\circ}$ ano de uma escola pública de Campo Grande - MS viessem a produzir. Consideramos conteúdos geométricos pela afinidade que tínhamos para com os mesmos, como também pelo favorecimento em relação às atividades manipulativas (dobrar, recortar, medir, entre outras) e para a elaboração de conjecturas.

Para finalizar, descrevemos aspectos teóricos em relação a conjecturas e provas de propriedades, bem como algumas das considerações e perspectivas que tivemos a partir de nossas análises.

\section{CONJECTURAS E PROVAS MATEMÁTICAS}

Assumimos que uma conjectura é uma proposição que ainda não foi provada e tampouco refutada podendo ser verdadeira ou falsa. É importante destacar que na organização dedutiva da matemática, quando a conjectura é verdadeira apenas para alguns casos ela é falsa, pois bastaria um contraexemplo para invalidá-la. Por outro lado, quando se consegue provar que ela é verdadeira ela também deixa de ser uma conjectura e, nesse caso, passa a ser chamada de teorema.

Quando se trata de alunos de ensino fundamental que ainda não conhecem a propriedade relativa à medida da soma dos ângulos internos do triângulo, por exemplo, a suposição de que ela resulta sempre $180^{\circ}$ é uma conjectura até que venha a ser refutada ou provada, passando a adquirir status de proposição válida para essa comunidade.

Quanto à elaboração de conjecturas, "[...] é o processo de supor ou de perceber se uma afirmação é verdadeira, o que induz a necessidade de investigar a sua veracidade" (MASON et al. 1982, p. 71 apud MAGALHÃES; MARTINHO, 2014, p. 104). Esse processo pode envolver, por exemplo, a formulação da conjectura, a verificação de casos particulares por meio de diversos testes, a apresentação de motivos pelos quais se considera que ela é válida, a reformulação da conjectura, entre outros.

Existem diferentes maneiras pelas quais uma conjectura pode ser formulada, seja por meio da observação e/ou manipulação de dados, busca por regularidades, testes sucessivos, entre outros. No trabalho em sala de aula, nem sempre as conjecturas são explicitadas, pois elas podem ficar restritas ao pensamento do aluno (PONTE; BROCARDO; OLIVEIRA, 2003). Neste caso, discussões coletivas podem auxiliar o professor a compreender melhor a conjectura formulada e os motivos pelos quais se acredita que ela é válida. Por vezes, os próprios alunos concluem a falsidade de determinadas hipóteses levantadas mediante a exposição dos argumentos de colegas, como observamos em nosso trabalho maior (KRAKECKER, 2016).

Outra característica do grupo investigado e que, segundo Ponte (2003; 2006), é comum em alunos que possuem pouco contato com a elaboração de conjecturas, é a conclusão de que elas são verdadeiras após 
as terem testado apenas para alguns casos. Como destacamos anteriormente, nem todas as formulações são verdadeiras ou verdadeiras para todos os casos possíveis, por isso é importante o trabalho de validálas tomando como base princípios matemáticos válidos. Nesse sentido, deixa-se de operar com a "lógica natural" utilizada espontaneamente pelos alunos, passando a considerar "a lógica formal" envolvida (ARSAC, 1982). Assim,

A introdução da ideia da prova matemática pode ser feita gradativamente, restringindo-se, numa fase inicial e com os alunos mais novos, à procura de uma justificação aceitável que se baseie num raciocínio plausível e nos conhecimentos que os alunos possuem. À medida que os alunos vão interiorizando a necessidade de justificarem as suas afirmações e que as suas ferramentas matemáticas vão sendo mais sofisticadas, vai se tornando mais fácil realizarem pequenas provas matemáticas. (PONTE; BROCARDO; OLIVEIRA, 2003, p. 38)

Nessa linha de pensamento, algumas provas simples, cujo raciocínio seja plausível podem ser consideradas pelo professor e pelo grupo de alunos. Balacheff (1988), por exemplo, apresenta um modelo de classificação hierárquica para as provas que contempla desde validações fundamentadas em exemplos ou casos particulares até as demonstrações. Então, quando um grupo de alunos aceita determinada proposição como sendo válida em determinado momento, surge a noção de prova. Neste caso, "a prova tem valor relativo, serve apenas para o grupo que a aceita, que se sentiu convencido pelo argumento" (SALES, 1996, p. 36) e, assim, uma explicação pode ter o status de prova para certo grupo, mas para outro, não (ARSAC, 1992).

Balacheff (1988) classifica as provas em dois níveis sendo o primeiro deles referente às provas pragmáticas as quais são apoiadas em ações realizadas em alguns exemplos singulares, sem que haja elementos voltados à generalização. Por isso, podemos dizer que são baseadas em manipulações e exemplos. Neste nível, Balacheff identificou dois tipos de prova, a saber, empirismo ingênuo e experimento crucial. Quando a afirmação é obtida com base na observação de casos particulares, como, por exemplo, quando se conclui que a soma das medidas dos ângulos internos de qualquer triângulo é $180^{\circ}$, a partir da manipulação de algumas poucas figuras, dizemos que o tipo de prova apresentada é do tipo empirismo ingênuo. Caso o aluno desconfie da validade da afirmação com o teste apenas desses poucos resultados e decida testar conjectura em um triângulo atípico, por exemplo, com ângulos de medidas $10^{\circ}, 120^{\circ}$ e $70^{\circ}$, podemos inferir que ele apresentou o tipo de prova experimento crucial.

O segundo nível estabelecido pelo autor recebe o nome de provas intelectuais, nas quais as conclusões obtidas são fundamentadas em deduções, com base em propriedades válidas e neste nível já aparece a generalização. As provas são dos tipos exemplo genérico e experimento mental. 0 exemplo genérico ocorre quando o aluno escolhe um caso particular para ser o representante da sua classe de objetos. Seria este o tipo de prova caso os alunos utilizassem noções sobre retas paralelas e transversais e ângulos de meia volta para relacionar a congruência de ângulos no triângulo. Conforme a figura que segue, os ângulos de medidas p e r / q e t são congruentes. Então, $\mathrm{p}+\mathrm{s}+\mathrm{q}=\mathrm{r}+\mathrm{s}+\mathrm{t}=180^{\circ}$.

Figura 1 - Exemplo do tipo de prova exemplo genérico

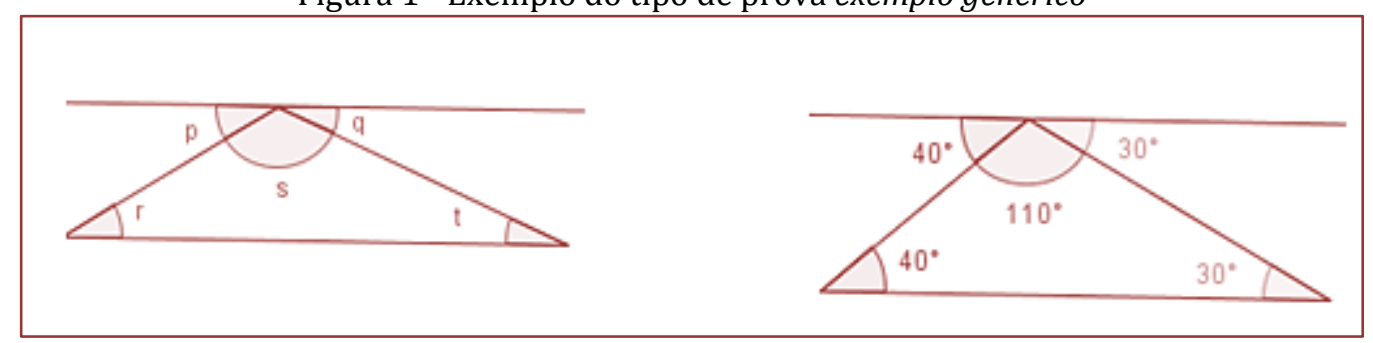

Fonte: Os autores 
E, por último, têm-se o experimento mental, em que a validação é baseada em uma proposição genérica. Para exemplificar este tipo de prova, podem-se citar as demonstrações formais, como quando se demonstra a partir de postulados e axiomas sem precisar se prender ao auxílio da figura. Quando ela é utilizada, serve apenas como suporte ao raciocínio, representando generalidade,

A principal diferença entre estes dois últimos tipos de prova consiste na generalização, que no primeiro caso é realizada raciocinando sobre um elemento particular. Já no experimento mental, mesmo diante de uma representação qualquer, está-se pensando para quaisquer elementos do grupo a que pertence essa representação. (KRAKECKER, 2016, p. 40, grifo do autor)

Na prática, a seguinte resposta dada a partir da figura 2 consiste em um tipo de prova experimento mental: dado um triângulo $\mathrm{ABC}$, considere a reta $\mathrm{r}$ que passa pelo vértice $\mathrm{C}$ e paralela à reta determinada por $\mathrm{A}$ e $\mathrm{B}$. $\mathrm{O}$ ponto $\mathrm{C}$ determina sobre $\mathrm{r}$ duas semirretas. Sejam $\mathrm{X}$ e $\mathrm{Y}$ dois pontos, um em cada uma destas semirretas. Temos: medidas $X \widehat{C} A+\widehat{C}+B \widehat{C} Y=180^{\circ}$. Como a reta $A C$ é transversal às paralelas $r$ e $A B$, segue da proposição "duas retas paralelas interceptadas por uma reta transversal determinam ângulos correspondentes

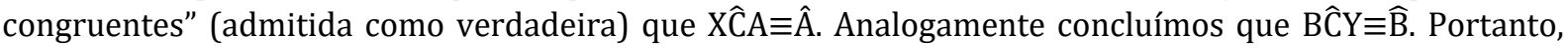
medidas $\hat{\mathrm{A}}+\widehat{\mathrm{B}}+\widehat{\mathrm{C}}=\mathrm{X} \widehat{\mathrm{C} A}+\mathrm{BC} Y+\widehat{\mathrm{C}}=180^{\circ}$.

Figura 2 - Exemplo do tipo de prova experimento mental

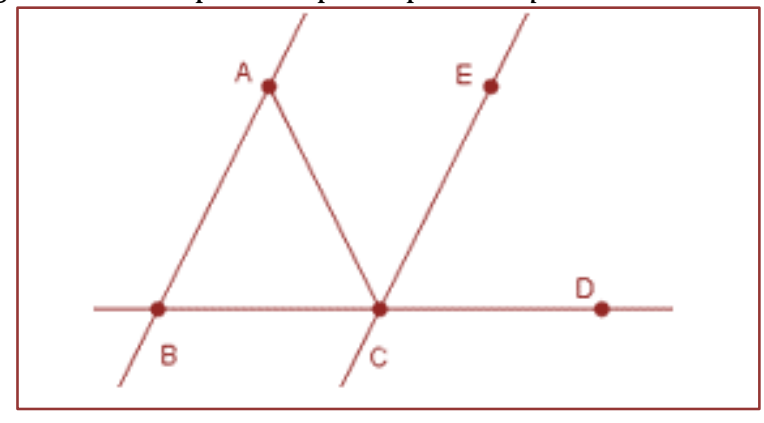

Fonte: Os autores

\section{PROCEDIMENTOS METODOLÓGICOS}

Com relação aos procedimentos metodológicos, nosso trabalho teve como norte a Engenharia Didática (ARTIGUE, 1996), que pressupõe quatro fases: análises preliminares, concepção e análise a priori, experimentação e análise a posteriori e validação.

Uma vez definido o tema com o qual trabalharíamos, ângulos de polígonos, passamos a realizar leituras acerca do mesmo, abrangendo também a geometria, seu ensino, o livro didático, a elaboração de conjecturas, a produção de provas, entre outras. Neste cenário, procuramos artigos, dissertações e teses cujo tema e objetivos se aproximassem daqueles que estávamos explorando. Dentre tais trabalhos, podemos citar Oliveira (2009), que analisou a evolução dos argumentos presentes nas validações em relação às construções geométricas em uma turma de alunos do $8^{\circ}$ ano do Ensino fundamental; Mello (2009), que objetivou elaborar uma sequência didática com alunos de oitava série do Ensino Fundamental, considerando a demonstração; Piccelli (2010), que investigou a elaboração e a validação de conjecturas em geometria plana por alunos do primeiro ano do Ensino Médio.

Exploramos, também, documentos norteadores do Ensino Fundamental, tais como os Parâmetros Curriculares Nacionais e o que estes orientam no que se refere ao ensino da Geometria e à elaboração de conjecturas e provas. Uma coleção de livros didáticos também foi objeto de estudo quanto à abordagem do conteúdo em questão, especificamente o tema ângulos de polígonos e respectivas provas de propriedades.

Esse primeiro trabalho foi retomado e aprofundado ao longo da investigação conforme sentíamos necessidade. Esta fase de análises preliminares subsidiou tanto a escolha das variáveis didáticas, quanto à elaboração das atividades com vistas à produção de conjecturas e provas de propriedades, realizado durante a segunda fase da Engenharia. Nela, além da elaboração da sequência de atividades, tentamos prever e descrever possíveis respostas, resoluções e comportamentos, tanto dos alunos como nossos, diante da implementação da proposta. 
A fase da experimentação consiste no contato direto com os alunos e com os dados produzidos por eles diante das atividades propostas, bem como por meio de diálogos, registros e entrevista. Nesse momento, aplicamos nossas atividades com alunos de $8^{\circ}$ ano de uma escola municipal de Campo Grande - MS em horário extraescolar. Foram desenvolvidas sete sessões com duração média de duas horas cada e, devido à participação voluntária, analisamos os dados produzidos pelos sete alunos de maior frequência nos encontros.

De acordo com a sondagem inicial que fizemos junto ao professor regente da turma, identificamos que, embora os alunos já tivessem tido algum contato com o tema em anos anteriores, este não ocorreu de modo aprofundado. Ademais, o conteúdo relativo a ângulos de polígonos reservado ao $8^{\circ}$ ano ainda não havia sido abordado em sala. Por este motivo, nas primeiras sessões, tínhamos a intenção de identificar e, também, revisar conceitos e ideias fundamentais para o andamento da proposta, como, por exemplo, medir ângulos utilizando o transferidor e a soma das medidas de ângulos complementares.

A experimentação foi realizada pela primeira autora deste trabalho junto de um colega, ambos, membros do Grupo de Estudos em Didática da Matemática - DDMat ${ }^{9}$, dentro do qual a pesquisa estava inserida. Os conteúdos trabalhados nas sessões foram: ângulo raso, ângulo de uma volta, ângulos suplementares, ângulos complementares, retas paralelas e transversais, ângulos opostos pelo vértice (OPV), ângulos formados por retas paralelas e transversal, ângulos internos de triângulos, ângulos internos de polígonos quaisquer, ângulos externos de polígonos quaisquer.

De posse dos dados produzidos pelos alunos, realizamos as análises a posteriori onde olhamos para a transcrição das falas, como também para os protocolos (produções escritas) num processo de análise, considerando o objetivo e os referenciais adotados. Esse movimento constituiu-se de idas e vindas entre as análises feitas logo após a experimentação e aquelas feitas anteriormente, numa tentativa de amarrar as duas em apenas uma.

\section{ELEMENTOS DE ANÁLISE}

Na primeira sessão, observamos que os alunos não possuíam muitos conhecimentos acerca de ângulos e suas propriedades e, por isso, foi necessário realizar uma explanação sobre o uso do transferidor e o modo como medir ângulos. As discussões ocorreram de forma tímida e os protocolos permaneceram praticamente em branco. Mesmo assim, por ser o primeiro encontro com a proposta de trabalho, consideramos que os resultados foram satisfatórios, já que, quando são propostas atividades que exigem justificativas que não são comuns na sala de aula, o registro escrito é um desafio a mais, porque exige um tipo de representação que geralmente não é utilizado (PONTE; BROCARDO; OLIVEIRA, 2003).

No segundo encontro, os alunos formularam a conjectura de que os ângulos OPV possuem medidas iguais e para validá-la, apoiaram-se em suas próprias construções, como podemos observar na resposta de Lisa $^{10}$.

Classificamos a resposta de Lisa como sendo o tipo de prova experimento crucial, de nível pragmático, cuja conclusão é baseada em diversos exemplos, sobretudo em algum bem particular, como é possível observar nos desenhos do protocolo. É importante destacar que mesmo diante de poucas construções, o fato de Lisa ter dito "Olha aqui o tamanho desses!" significa que para ela aquele desenho cujo prolongamento das semirretas foi pequeno, ao qual estava se referindo, foi o caso não familiar, atípico e determinante na validação da conjectura.

\footnotetext{
${ }^{9}$ http://grupoddmat.pro.br/index.php/home/

10 Todos os nomes dos alunos utilizados neste trabalho são fictícios.
} 
Figura 3 - Protocolo da aluna Lisa.

Pesquisadora: Será que sempre, quando tivermos dois segmentos concorrentes como dessa forma, os ângulos OPV terão mesma medida?

Ana: Não

Lisa: Sim! Olha o que eu fiz... Deu a mesma coisa! Olha aqui, eu fiz um monte, olha! Deu tudo a mesma coisa! Olha aqui o tamanho desses!

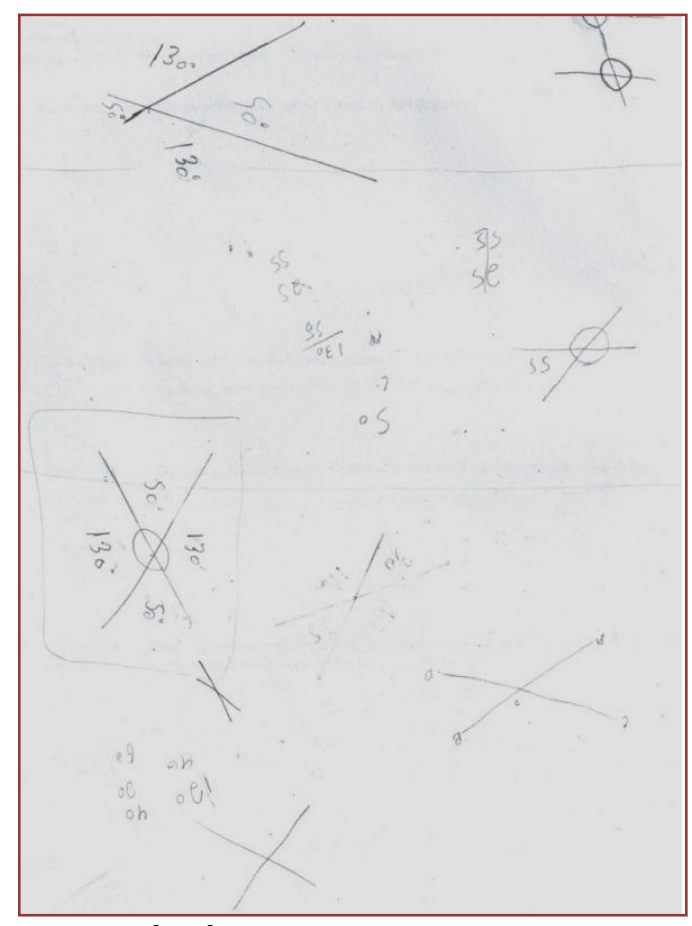

Fonte: Dados da pesquisa.

Na terceira sessão, retomamos esse assunto, ângulos OPV, pois percebemos que nem todos os alunos sentiram-se convencidos pelo argumento de Lisa, o que significa que a validação da conjectura não adquiriu status de prova para o grupo de alunos. A partir deste dia, ao final de cada sessão, passamos a realizar uma prova de cada propriedade que estava sendo abordada com o intuito de mostrar aos alunos outras possibilidades de justificações, além daquelas que vinham sendo apresentadas (de nível pragmático). Esse momento era de discussão, pois os alunos participavam ativamente da construção da prova. Sobre isso, Boavida et al. inferem que

Nem sempre os alunos conseguem provar as conjecturas formuladas, nem sequer acompanhar uma prova apresentada pelo professor. Este facto não constitui um factor negativo, pois a actividade de formulação de conjecturas tem, em si mesmo, valor educativo. Além disso, este facto pode proporcionar boas oportunidades para os alunos começarem a compreender a natureza do trabalho em Matemática onde a formulação de conjecturas e a sua prova, frequentemente, não ocorrem em simultâneo. (BOAVIDA et al., 2008, p. 89)

Nem sempre é fácil fazer com que os alunos compreendam a necessidade de justificação de conjecturas, sobretudo quando estas parecem ser verdadeiras e resistem a vários testes. Contudo, esse é um trabalho que se faz necessário.

No quarto encontro, trabalhamos com ângulos formados por retas paralelas e transversais, assim como atividades de aplicação e reinvestimento de noções que até então foram abordadas. A quinta sessão foi dividida em dois momentos. No primeiro deles distribuímos diversos triângulos com tamanhos e formas diferentes e solicitamos aos alunos que medissem seus ângulos internos. A conjectura pretendida foi elaborada, como percebemos no diálogo entre Wendy e Peter

Wendy: Quanto deu a soma aqui?

Peter: $180^{\circ}$ eu acho...

Wendy: Olha deu $180^{\circ}$ de novo!

Algum tempo depois...

Wendy: Deu $180^{\circ}$ de novo!

Peter: Não está dando todos $180^{\circ}$ não!

Wendy: Está dando todos $180^{\circ}$ !
Peter: Você já mediu quantos?

Wendy: Quatro!

Peter: Eu estou no terceiro ainda!

Algum tempo depois...

Wendy: Nossa está dando todos $180^{\circ}$ ! Eu acho que vai dar todos $180^{\circ} \ldots$ 
Peter afirma que nem todas as somas feitas estão resultando em $180^{\circ}$ e observamos em sua folha de anotações que seus resultados, para a soma das medidas dos ângulos internos dos triângulos, foram $163^{\circ}$ (um caso), $182^{\circ}$ (três casos) e $184^{\circ}$ (dois casos). Nas anotações de Wendy, por outro lado, todas as somas resultam em $180^{\circ}$. E aqui, não é possível concluir se ele arredondou as medidas dos ângulos ou se, percebendo para um ou dois casos a recorrência desse valor, modelou os demais. Depois de um processo de experimentação no qual Wendy mediu os ângulos internos de vários triângulos e somou as medidas encontradas, ela diz achar que "vai dar todos $180^{\circ}$ ". Esse é um caso em que há a conjectura implícita de que a soma das medidas dos ângulos internos de um triângulo é $180^{\circ}$.

Em seguida, naquele momento de exploração, pedimos aos alunos que pintassem e recortassem os ângulos internos dos triângulos e os juntassem em torno de um único vértice. Wendy logo se pronuncia,

Wendy: Ahhh! Não falei que iria dar $180^{\circ}$ ! Deu a metade, olha... $180^{\circ}$ aqui mais $180^{\circ}$ vai dar $360^{\circ}$ !

As provas produzidas permaneceram no nível pragmático, pois os alunos apoiaram-se na atividade experimental que foi realizada. Vemos, assim como no trabalho de Mello (1999), que quase todos os estudantes que fizeram esta mesma atividade, lembram e a utilizam para justificar a medida da soma dos ângulos internos de triângulos, mesmo passado algum tempo. Desta forma, consideramos que estas atividades são importantes para que o aluno se sinta ativo e faça parte do seu processo de aprendizagem e para que possa estabelecer associações entre diferentes noções matemáticas. Entretanto, elas devem compor o caminho para se chegar à formalidade que a matemática exige.

Na sessão posterior, os alunos realizaram atividades de aplicação e reinvestimento de noções que havíamos trabalhado até o momento. Além disso, propusemos questões relativas à soma dos ângulos internos de quadriláteros, a fim de que conjecturas e provas a esse respeito fossem elaboradas. Peter apresentou a seguinte resposta:

Figura 4 - Protocolo do aluno Peter

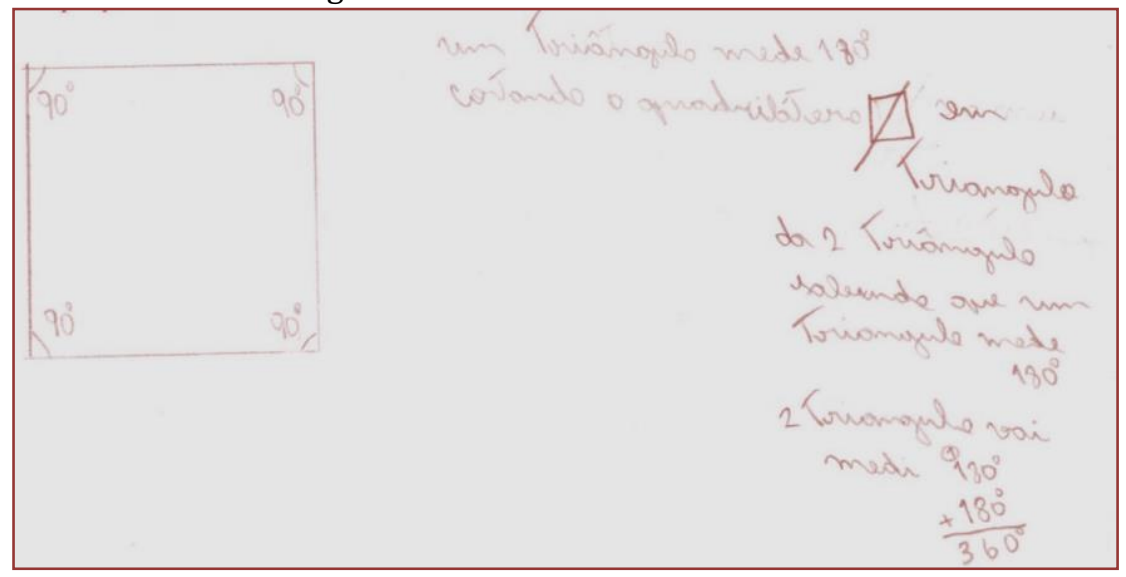

Fonte: Dados da pesquisa.

O aluno dividiu o quadrilátero em triângulos e organizou seu discurso dedutivo. Destacamos que mesmo que Peter tenha sido influenciado pela atividade experimental realizada (juntar os ângulos do quadrilátero convexo em torno de um único vértice), ele apresenta uma sequência lógica de afirmações a partir da representação de um polígono de quatro lados. Nesse sentido, classificamos a prova apresentada como sendo exemplo genérico. Essa classificação seria outra, caso Peter respondesse algo do tipo "é $360^{\circ}$, por que quando recortamos e juntamos os dois triângulos, vimos que deu dois triângulos". Para Balacheff (1987), quando se trata de uma evolução referente às provas, em específico das provas pragmáticas para as intelectuais, o processo é marcado não só por uma evolução da natureza do conhecimento, mas também por uma evolução das características linguísticas, como vem demonstrando Peter.

Outro elemento que nos fez atribuir a referida classificação à prova realizada, foi a presença de duas representações do quadrado em seu protocolo. Numa delas, aspectos como o traço exato, a utilização da régua e a igualdade de certas medidas foram consideradas por Peter importantes para "constatar" a veracidade da conjectura. Na segunda (Figura 4), não há preocupação alguma em obedecer a tais regras, de modo que o estatuto passa a ser outro. Arsac (1982) sublinha que, pouco a pouco, o aluno deverá 
evoluir, assim como o estatuto da figura em geometria. Isso é difícil de ser explicado ou definido precisamente, mas se deixará de medir ou constatar com réguas ou transferidores para raciocinar ou ainda deduzir a partir da figura. Ademais, acreditamos que a justificativa apresentada por Peter pode ter sido influenciada pela nossa opção em discutir provas de propriedades trabalhadas a cada sessão, mostrando que é possível de se atingir níveis de provas intelectuais.

No último encontro, tínhamos a intenção de formular conjecturas acerca da soma das medidas dos ângulos externos de triângulos a partir da manipulação de exemplos produzidos pelos próprios alunos. Isso foi observado, por exemplo, no diálogo entre Mary e Wendy:

Wendy: $330^{\circ} \ldots$

Mary: $365^{\circ}$... Não vai dar... Tem mais que $335^{\circ}$

Wendy: 0 meu deu $330^{\circ} \ldots$

[...]

Mary: $40^{\circ}$ aqui. Dá $120^{\circ} \ldots$

Wendy: Por que aqui deu $120^{\circ}$ ?

Mary: $380^{\circ} \ldots$ Deu $365^{\circ}$, Wendy...

Wendy: 0 meu deu $360^{\circ} \ldots$

Mary: Por que aqui deu... E aqui deu $360^{\circ}$ ? Por que o quadrado...

Wendy: Dentro... Dentro tem que dar $180^{\circ}$ [referindo-se aos ângulos internos do triângulo] Aqui deu $180^{\circ}$ certo?

Mary: Mas tem que medir o de fora...

Wendy: Verdade...

Inicialmente, as alunas não distinguem ângulos internos e externos, mas ao longo da discussão este aspecto é resolvido entre as próprias alunas, evidenciando a autonomia já adquirida. Além disso, há a exploração das medidas dos ângulos das figuras e, por meio disso, a formulação da conjectura. A justificativa escrita de Mary e Wendy foi classificada como empirismo ingênuo, pois elas escreveram que a resposta solicitada fora $360^{\circ}$, pois haviam medido com o transferidor. Este foi um aspecto que se mostrou evidente em quase todas as sessões, já que os alunos justificavam com respostas escritas como se estivessem a nos contar o motivo pelo qual acreditavam que suas respostas estavam corretas. As alunas ainda não produziram argumentos escritos de provas intelectuais, como foi o caso de Peter e James (que neste dia trabalharam juntos).

\section{CONSIDERAÇÕES E PERSPECTIVAS}

Acreditamos que a produção de conjecturas, assim como havia nos sinalizado Ponte, Brocardo e Oliveira (2003), ocorre de diversas maneiras e em diferentes situações. Em nosso caso, a manipulação do transferidor foi fundamental para que os alunos elaborassem suas conjecturas, assim como as atividades experimentais nas quais foi preciso desenhar, medir, recortar, manipular, entre outros procedimentos. Destacamos que o trabalho em duplas também foi de grande valia, uma vez que possibilitou debates acerca das resoluções e das próprias atividades. Como a participação dos alunos foi voluntária, nem sempre tínhamos os mesmos alunos a cada encontro e, por isso, a composição das duplas quase nunca era a mesma. Vimos que este aspecto possibilitou que eles trabalhassem com parceiros diferentes, discutissem coisas diferentes e aprendessem coisas também diferentes.

Em relação à validação de conjecturas, conseguimos identificar algumas provas, sendo a maioria situada no nível das provas pragmáticas, em que as conclusões foram fundamentadas em exemplos particulares, manipulações, dentre outros, sem haver elementos relacionados à generalização. No processo de validação, destacamos a escrita em linguagem matemática, uma vez que os alunos, de modo geral, escreviam nos protocolos como se estivessem nos contando como ou porque acreditavam que sua resposta estivesse correta.

Nesse contexto, Balacheff (1987) destaca que quando se trabalha com uma geometria baseada na observação, a natureza do conhecimento do qual o aluno dispõe não lhe permite satisfazer as exigências de uma demonstração de modo imediato e que, independentemente da negociação de um novo contrato 
didático, não se trata de uma simples passagem das provas pragmáticas até a demonstração. Esta é constituída por uma sucessão de construções sobre o terreno do conhecimento e da racionalidade e que, portanto, requer certo tempo. Acreditamos que um trabalho prolongado com os alunos poderia levá-los a atingir níveis mais elevados de prova, pois as ferramentas para isso aos poucos iam passando a fazer parte do repertório deles, como foi possível observar tanto nos diálogos quanto nos protocolos.

É importante dizer que para outros temas, diferentes daquele com o qual trabalhamos, um intenso trabalho também precisará ser desenvolvido pelo professor ou pelo pesquisador, pois para a produção de conjecturas, e principalmente para a produção de provas de propriedades, é preciso que haja a utilização de algumas noções anteriormente trabalhadas. Aos poucos, os alunos passam a entrar nesse "novo jogo" e a procurar elementos de validação para suas conjecturas, afinal, nos primeiros encontros, como os alunos poderiam apresentar provas do tipo experimento mental, por exemplo, se não as conheciam? Como poderiam justificar suas respostas se não o fazem sempre?

Destacamos que em meio a esta proposta, as atividades ou sessões cuja intenção consistiu em reinvestir noções anteriormente trabalhadas, foram importantes para que os alunos colocassem em prática o "conhecimento teórico", podendo estabelecer relações de aplicação, mesmo que dentro da lógica interna da matemática. Para nós, foram oportunidades de observar a (não) mobilização das noções que estavam em jogo em prol da realização da tarefa.

Em meio a um percurso muito distante da linearidade que a organização desta ou de qualquer outra produção possa sugerir, surgiram-nos inquietações as quais não foram possíveis de serem exploradas. Então, como seria desenvolver um trabalho que abarcasse conjecturas falsas ${ }^{11}$ e que, a partir delas, se discutisse a necessidade da prova matemática? Em que medida a manipulação de softwares educacionais teria contribuído para a elaboração de conjecturas? Como é discutida, na formação de professores, a produção de conjecturas e provas de propriedades?

Por último, como estão Lisa, Peter, Mary, Wendy, Miguel, João e James, alunos cujas produções foram analisadas para que chegássemos a tais considerações? O que eles teriam a nos dizer? 0 que eles nos diriam sobre o tema com o qual trabalhamos? Enfim...

\section{REFERÊNCIAS}

[1] Arsac, G. et al. Initiation au raisonnement déductif au collège. Lion-França: Presses Universitaires de Lion, 1992.

[2] Artigue, M.Engenharia didática. In: BRUN, Jean (Org.). Didáctica das Matemáticas. Lisboa: Instituto Jean Piaget, 1996.

[3] Balacheff, N. Processus de prouve et situations de validation. Educational Studies in Mathematics, nำ18, 1987, p.147-176.

[4] Balacheff, N. Une étude des processus de preuve em Mathématique chez lês élèves de collège. 1988. Tese (Doutorado)- Grenoble: Université Joseph Fourier, 1988.

[5] Boavida, A. M. et.al. A experiência matemática no Ensino Básico. Programa de formação contínua em Matemática para professores do 1.ำ e 2.ํㅡㄹ Ciclos do Ensino Básico. Lisboa: Ministério da Educação, 2008.

[6] Brasil, Ministério da Educação e do Desporto. Secretaria de Educação Fundamental. Parâmetros Curriculares Nacionais: Matemática, 5a a 8éries. Brasília, 1998.

[7] Brasil, Parâmetros Curriculares Nacionais: 1aa a 4⿳⺈ séries. Brasília: MEC/SEF, 1997.

[8] Krakecker, L. Produção de Conjecturas e Provas de propriedades de ângulos de polígonos: um estudo com alunos do $8^{\circ}$ ano do Ensino Fundamental. 2016, 150f. Dissertação (Mestrado)- Universidade Federal de Mato Grosso do Sul, Mestrado em Educação Matemática, Campo Grande, 2016.

[9] Magalhães, M. da G.; Martinho, M. H. O desenvolvimento da argumentação matemática no estudo das funções racionais. Quadrante, v. XXIII, no 1, 2014.

[10] Mello, E. G. S. Uma sequência didática para a introdução do seu aprendizado no ensino da geometria. 1999, 189f. Dissertação (Mestrado em Educação Matemática)- Universidade Pontifícia Católica de São Paulo, São Paulo, 1999.

${ }^{11}$ Aqui, não se trata da elaboração de conjecturas falsas, mas da exploração das mesmas, independente de terem sido ou não formuladas pelos alunos. 
[11] Oliveira, S. G. da S. Um estudo de argumentações produzidas por alunos do 8o ano em atividades de construções geométricas envolvendo pontos notáveis de triângulo. 2009, Dissertação (Mestrado)- Universidade Federal do Mato Grosso do Sul, Mestrado em Educação Matemática, Campo Grande, 2009.

[12] Piccelli, P. H. Processos de validação de conjecturas em geometria plana. 2010, 135f. Dissertação (Mestrado em Educação Matemática)- Universidade Federal de Mato Grosso do Sul, Campo Grande, 2010.

[13] Ponte, J.P; Brocardo, J. Oliveira, H. Investigações Matemáticas na sala de aula. 3. ed. Belo Horizonte: Autêntica, 2003.

[14] Sales, A. 0 ensino de matemática no $1^{\circ}$ grau: um estudo sobre o significado do conhecimento geométrico para alunos da 8a série. 1996. Dissertação (Mestrado em educação)- Universidade Federal de Mato Grosso do Sul, Campo Grande, 1996.

[15] Rocha, A., Ponte, J. P. Aprender Matemática investigando. Zetetiké, v.14, n. 26, p. 29-54, 2006. 


\section{Capítulo 8}

A resolução de problemas no contexto da álgebra elementar: Uma investigação dos saberes $e$ das práticas do professor de matemática de $7^{0}$ e $8^{\circ}$ anos do ensino fundamental

Valquírio Firmino da Silva

Gilberto Francisco Alves de Melo

Resumo: Este artigo baseia-se na pesquisa de mestrado do autor, cujo objetivo foi investigar os saberes e as práticas produzidos por professores no ensino da matemática via Resolução de Problemas no contexto da álgebra elementar. A investigação é um estudo de caso, de caráter qualitativo, que associa a pesquisa bibliográfica à de campo. Foi desenvolvida com a colaboração de quatro professores de matemática do $7^{\circ}$ e do $8^{\circ}$ ano do Ensino Fundamental, informantes que trabalhavam em escolas públicas de Rio Branco, no Estado do Acre, em 2014. Os resultados mostram que os saberes e as práticas dos professores em relação à resolução de problemas (como metodologia) no ensino de álgebra elementar apresentam limitações decorrentes da formação inicial lacunar e das precárias condições de trabalho; no entanto, a vivência da Oficina de Resolução de Problemas possibilitou a mobilização de saberes experienciais e curriculares de álgebra elementar.

Palavras-chave: Saberes docentes; Prática pedagógica; Resolução de problemas; Ensino de álgebra; Ensino Fundamental. 


\section{INTRODUÇÃO}

Nos últimos anos, o ensino da matemática vem passando por mudanças no campo metodológico, sobretudo no que se refere aos métodos de abordagem dos conteúdos, cuja diretriz aponta para a ideia de que o professor deve contextualizar o assunto, isto é, deve partir de situações-problema para estimular o raciocínio matemático nos alunos, como se verifica na proposta curricular nacional e na do Estado do Acre.

Diante disso, a pesquisa desenvolvida preocupou-se em discutir essa nova abordagem metodológica do ensino da matemática, enfocando, primordialmente, a observação do emprego da resolução de problemas como forma de abordagem dos conteúdos em sala de aula pelos professores, no intuito de investigar os saberes e as práticas já construídos e em reelaboração pelos docentes no ensino dessa disciplina. Além disso, buscou-se compreender como os professores concebem e desenvolvem essa metodologia na sua prática pedagógica, particularmente no ensino de álgebra elementar.

Percebeu-se que os alunos do Ensino Fundamental II apresentam dificuldades em matemática, como a falta de compreensão da situação-problema e a incapacidade de elaborar um plano estratégico para chegar a uma solução coerente, durante a resolução de problemas matemáticos. A hipótese básica é que isso decorre de alguns fatores, dos quais o mais crítico é a falta de saberes, não só do educando, mas também do educador, o qual não desenvolveu habilidades para ensinar matemática via resolução de problemas. 0 fato de o professor não estabelecer diferença entre problema e exercícios reforça tal situação; há, ainda, o desafio de romper com concepções e práticas dogmáticas no campo do ensino de matemática.

No decorrer da investigação, realizou-se uma revisão bibliográfica para discutir a temática proposta, que enfatiza a resolução de problemas, o ensino de álgebra e as práticas pedagógicas associadas aos saberes docentes, buscando apresentar aspectos e dimensões que vêm se destacando no cenário da Educação Matemática; em seguida, abordaram-se questões metodológicas. Por fim, apresentaram-se as contribuições da pesquisa realizada para a melhoria do ensino e da aprendizagem da matemática frente ao uso da Resolução de Problemas como método de abordagem de conteúdos.

\section{FUNDAMENTAÇÃO TEÓRICA}

\subsection{CONSIDERAÇÕES SOBRE A RESOLUÇÃO DE PROBLEMAS}

A abordagem dos conteúdos por meio da resolução de problemas é uma das tendências atuais em Educação Matemática, cujo objetivo é propor o desenvolvimento de conceitos matemáticos mais significativos para o aluno. Durante algum tempo, a resolução de problemas foi utilizada como um fim para o ensino de matemática. Porém, a partir dos anos 1990, passou a ser vista como uma metodologia de ensino, isto é, deixou de ser um fim para ser um dos meios pelo qual se deveria ensinar matemática. Nesse sentido, Onuchic (1999) diz que a intenção de ensinar matemática por meio de resolução de problemas passa de

[...] ter um papel de atividade limitada de engajar os alunos, depois da aquisição de certos conceitos de determinadas técnicas, para ser tanto um meio de adquirir novo conhecimento como um processo no qual pode ser aplicado àquilo que previamente havia sido construído (ONUCHIC. In: BICUDO, 1999, p. 208).

Essa abordagem da matemática se contrapõe à prática tradicional do ensino da disciplina, que se baseava em técnicas de memorização, no uso de regras e algoritmos e na repetição de exercícios. Para reforçar isso, Onuchic e Allevato (2004) destacam que

[...] a resolução de problemas têm como propósito fazer com que os alunos possam pensar matematicamente, levantar ideias matemáticas, estabelecer relações entre elas, saber se comunicar ao falar e escrever sobre elas, desenvolver formas de raciocínio, estabelecer conexões entre temas matemáticos e de fora da matemática e desenvolver a capacidade de resolver problemas, explorá-los, generalizá-los e até propor novos problemas a partir deles (ONUCHIC; ALLEVATO. In: BICUDO; BORBA, 2004, p. 218).

Outro aspecto importante refere-se às diferenças entre problemas e exercícios, pois existe grande confusão entre as definições de ambos. Desse modo, julga-se oportuno esclarecer as diferenças entre os dois termos na prática pedagógica. Acerca desse assunto, Pozo (1998) sustenta que, de um lado, uma 
situação é vista como um exercício quando já se tem em mente os procedimentos que permitem solucionála, de forma mais ou menos imediata, sem exigir nenhuma forma de reflexão ou tomada de decisões sequenciadas. Então, embora o exercício seja necessário para consolidar habilidades instrumentais básicas, ele não deve ser confundido com problemas.

Por outro lado, um problema é uma situação desafiadora que exige do resolvedor criatividade, originalidade, reflexão e tomada de decisões, ou seja, demanda a construção de um conhecimento matemático próprio, como também a descoberta de respostas próprias. Dessa forma, o aluno terá um papel ativo e autônomo na sua aprendizagem, pois o conteúdo a ser aprendido será apresentado a partir de contextos significativos.

Em relação às perspectivas sobre a resolução de problemas, destacam-se as contribuições de Gazire (1988), que categoriza a resolução sob três prismas: a resolução de problemas como um novo conteúdo, como aplicação de conteúdos e como um meio de se ensinar matemática. Todas essas perspectivas podem ser trabalhadas em sala, dependendo dos objetivos da aula e do nível de maturidade dos alunos. Ressaltase que a primeira categoria apresentada por Gazire (1988) relaciona-se às ideias de Polya (1995); a segunda, possui fortes traços de ensino tradicional, porque valoriza a transmissão do conhecimento matemático, em detrimento da construção; já a terceira perspectiva propõe uma abordagem com enfoque na construção dos conceitos matemáticos pelo aluno.

Do que se expôs até aqui, destaca-se que esta pesquisa se identifica com a última perspectiva: resolução de problemas como um meio de se ensinar matemática, isto é, ensinar matemática por meio da resolução de problemas, sendo o problema o gerador do processo de ensino-aprendizagem.

\section{2. ÁLGEBRA E SUAS CONCEPÇõES}

Sabe-se que nos anos iniciais do Ensino Fundamental já é possível desenvolver e/ou explorar situações que contribuam para a formação do pensamento algébrico, como, por exemplo, identificar e descrever padrões numéricos e geométricos, regularidades numéricas, padrões em sequências de figuras geométricas e padrões em conjuntos de expressões numéricas.

Contudo, é especialmente nos anos finais do Ensino Fundamental (do 6o ano ao 9o) que as atividades algébricas serão ampliadas e formalizadas. Isso deve ocorrer, como expressam os PCN (1997), por meio da exploração de situações-problema, em que o aluno reconhecerá diferentes funções da álgebra (generalizar padrões aritméticos, estabelecer relação entre duas grandezas, modelizar, resolver problemas aritmeticamente difíceis), representará problemas por meio de equações e inequações (diferenciando parâmetros, variáveis, incógnitas, tomando contato com fórmulas) e ainda compreenderá a "sintaxe" (regras para resolução) de uma equação.

Verifica-se, conforme esses objetivos, que o ensino-aprendizagem da Álgebra Elementar deve acontecer a partir de situações-problema, fato que implica um ensino pautado na investigação, o que não será possível pelo uso de técnicas tradicionais, mas pela metodologia da resolução de problemas, que possibilita construção de estratégias. Nesses objetivos existem concepções subjacentes sobre a álgebra e seu ensino, cujo conhecimento é fundamental para a compreensão dos saberes e das práticas mobilizados pelos professores durante o seu fazer pedagógico. Há muitas pesquisas que apontam a identificação dessas concepções, dentre elas estão os estudos de Fiorentini, Miguel e Miorim (1993), Usiskin (1994) e outros, bases teóricas deste trabalho.

Sobre as concepções de álgebra, destacam-se aqui apenas as contribuições de Usiskin (1994), o qual apresenta quatro concepções de álgebra baseadas na importância que o uso das variáveis assume. A primeira é a aritmética generalizada, que entende a álgebra como ampliação dos conceitos da aritmética, partindo do estabelecimento de padrões, com a preservação das propriedades válidas para os números.

A segunda concepção, álgebra como estudo de métodos para resolver certos problemas, implica a tradução de uma situação-problema para uma linguagem algébrica, geralmente uma equação. Usiskin (1994) estabelece como terceira concepção de álgebra o estudo de relação entre grandezas. Possivelmente, o estudo das funções é o maior representante dessa concepção. Por fim, a quarta concepção é o estudo das estruturas que buscam entender que percepções matemáticas (tais como equivalências entre expressões, simplificações e outras atitudes matemáticas) podem ser úteis ou não para resolver os problemas em álgebra, como, por exemplo, fatorar a expressão " $\mathrm{x}^{2}$ - 9".

Diante dessas concepções de álgebra propostas pelo autor, percebe-se que elas se manifestam em diversos momentos da prática docente no ensino desse assunto. É importante destacar que a forma de o professor 
trabalhar os conceitos e procedimentos algébricos pode dificultar a aprendizagem do aluno. Assim, ao fundamentar sua prática em uma ou mais dessas concepções, o professor deve optar pela abordagem metodológica mais adequada para o ensino da álgebra e refletir sobre sua eficácia.

Uma dessas abordagens mais adequadas para favorecer o processo de ensino-aprendizagem de matemática seria a resolução de problemas, já que possibilita o desenvolvimento de aulas orientadas pela investigação e construção do saber, uma vez que prioriza o desenvolvimento de estratégias ou heurísticas, em vez de memorização/aquisição mecânica de algoritmos e fórmulas.

\subsection{SABERES E PRÁTICAS DOCENTES}

Os dados construídos da pesquisa foram problematizados em relação às classificações e tipologias/categorias de saberes docentes mobilizados pelos professores de matemática, no que concerne ao ensino da álgebra elementar mediada pela resolução de problemas. Acerca desse assunto, apresentamse a seguir as abordagens de autores, como Tardif (2002), Santos (2010) e Melo (2003), que concebem os professores na perspectiva de produtores de saberes construídos na prática profissional e não apenas como meros consumidores e/ou reprodutores de conhecimentos exteriores à sua prática.

Na discussão empreendida, Tardif (2002) formula alguns questionamentos:

Quais são os saberes que servem de base ao oficio de professor? Noutras palavras, quais são os conhecimentos, o saber-fazer, as competências e as habilidades que os professores mobilizam diariamente, nas salas de aulas e nas escolas, a fim de realizar concretamente as suas diversas tarefas? Qual é a natureza desses saberes? [...] como esses saberes são adquiridos? (TARDIF, 2002, p. 09).

Refletindo sobre essas questões, que são fundamentais para a compreensão dos saberes e das práticas que os professores constroem e reelaboram diariamente no exercício de sua complexa função, percebe-se que a produção de saberes docentes envolve um conjunto de condicionantes e o contexto no qual tais conhecimentos inserem.

Tardif (2002) propõe a existência de uma diversidade de saberes, considerando que ensinar é mobilizar diversos saberes, os quais são denominados saberes disciplinares, curriculares, experienciais e os da formação profissional.

Nessa perspectiva, o professor ideal, se existe, é aquele que reúne todos esses saberes, sendo capaz de dominar, integrar e mobilizar tais saberes como condição para desenvolver sua prática cotidiana com os alunos. Ainda nessa direção, Tardif (2002) afirma que os professores, na impossibilidade de controlar os saberes curriculares, disciplinares e da formação profissional, produzem ou tentam produzir saberes que determinam a sua prática, levando-os a se distanciarem daqueles saberes adquiridos fora dela.

Percebe-se que a experiência conduz o professor a realizar uma análise crítica daqueles saberes que foram construídos e/ou adquiridos antes ou fora da prática profissional, o que possibilita aos docentes um processo permanente de avaliação de todos os seus saberes.

Apresentando ideias análogas, Melo (2003, p. 77) atenta para "a possibilidade de considerar a prática como lócus de produção de saberes, [...]". Ainda nesse sentido, Santos (2010) afirma que todo saber implica um processo de aprendizagem e formação. Ele constatou que os professores revelam, por meio dos seus escritos, práticas com perspectivas voltadas para a produção de saberes significativos.

Melo (2003) também focalizou a produção e a apropriação de saberes docentes, destacando, em sua investigação, que a mobilização de saberes do professor ocorre em dois níveis de formação, quais sejam: o de compreender as dificuldades de seus alunos em álgebra elementar e o de revisar e ressignificar a sua Formação Inicial.

\section{METODOLOGIA DE PESQUISA}

A presente pesquisa, de cunho qualitativo, consiste num estudo de caso acerca dos saberes e das práticas pedagógicas de professores de matemática que trabalhavam com 7으 e 8o anos do Ensino Fundamental em escolas públicas de Rio Branco, no Estado do Acre, em 2014. 
A escolha do estudo de caso se justifica face à pertinência e aplicabilidade dessa modalidade para aprofundar estudos com temática e/ou problemática voltados à área da educação, conforme defendem Lüdke e André (1986).

Essa opção deve-se também ao fato de o estudo de caso enfocar uma situação, um fenômeno particular, tornando-o um tipo de estudo adequado para investigar problemas da prática educacional. Além disso, a capacidade heurística é outra contribuição desse tipo de pesquisa, pois pode levar à descoberta de novos sentidos, à expansão de experiências ou à confirmação de algo que já se sabia.

Para a construção dos dados foram utilizados os seguintes instrumentos: entrevistas semiestruturadas, questionário semiaberto, observações de aulas, diário de campo, pesquisa bibliográfica e as produções dos professores oriundas das atividades desenvolvidas na "Oficina de Resolução de Problemas", realizada no $2^{\circ}$ semestre de 2014 pelo pesquisador.

Quanto à análise, os dados foram classificados de forma sistemática por meio de seleção (exame minucioso), codificação (técnica operacional de categorização) e tabulação (disposição dos dados de forma a verificar as inter-relações). Essa classificação possibilita maior clareza, visando à construção das categorias de análise.

\section{ANÁLISE}

A análise consistiu em confrontar os dados construídos a partir dos instrumentos, já mencionados, à luz do referencial teórico, visando responder à questão de pesquisa: Como os professores de matemática manifestam saberes e práticas em relação à metodologia resolução de problemas no contexto da álgebra elementar no $7^{\circ}$ e no $8^{\circ}$ ano?

Para atingir esse objetivo, construíram-se categorias empíricas confrontadas com o aporte teórico de Polya (1995), em relação à resolução de problemas; de Tardif (2002), no que se refere aos saberes docentes; e de Usiskin (1994), no que tange ao ensino de álgebra elementar, ou seja, analisou-se o desenvolvimento quanto às (aos):

\subsection{CONCEPÇÕES DOS PROFESSORES SOBRE RESOLUÇÃO DE PROBLEMAS}

Verificou-se uma grande dificuldade dos quatro professores em fazer tal distinção, o que ficou evidente nas respostas da entrevista e do questionário e nas observações colhidas durante as aulas de matemática desses docentes. Um exemplo disso está no texto de um dos informantes, denominado P2, ao responder questionário: "No geral tento trabalhar primeiro exercícios de fixação, após eu trabalho com situações que reflitam problemas cotidianos".

Outra evidência é o relato do informante P4, quando diz, em resposta ao mesmo questionário: "Sempre após ensinar a base do assunto uso resolução de problemas para que os alunos fixem os conteúdos de forma significativa". É preciso destacar a presença da ação de "fixar" em ambos os relatos, expressa pelo substantivo "fixação", no primeiro, e pela forma verbal "fixem", no segundo, o que leva à inferência de que, apesar de os professores expressarem que usam a resolução de problemas como metodologia, suas práticas se fundamentam numa abordagem tradicional de ensino da Matemática. Isso porque, na percepção deles, a resolução de problemas se apresenta na perspectiva da "aplicação de conteúdos", como propõe Gazire (1988).

Ainda nesse sentido, percebe-se mais uma confusão, agora entre problema e contextualização: para os professores, uma situação contextualizada é um problema. Tal concepção evidencia-se na declaração de P2, em entrevista concedida ao pesquisador ${ }^{12}$ : "Se for para falar de problemas para nortear uma aula, lembro-me de uma aula [...] sobre a ida ao cinema, onde eu trabalho sobre a bilheteria, fazendo perguntas para eles e iam respondendo, ou seja, contextualizei para eles uma situação [...]".

\footnotetext{
${ }^{12}$ As entrevistas foram realizadas em dezembro de 2014, em Rio Branco-AC, e constituem material ainda inédito.
} 


\subsection{SABERES PRODUZIDOS E/OU MOBILIZADOS NA PRÁTICA DOS PROFESSORES EM RELAÇÃO À RESOLUÇÃO DE PROBLEMAS FRENTE À ÁLGEBRA ELEMENTAR}

A segunda categoria em discussão nesta pesquisa diz respeito aos saberes que os professores mobilizam ao ensinar a matemática em sua sala de aula numa abordagem de resolução de problemas. Antes de discuti-la, é necessário ressaltar uma das principais fontes desse saber: a formação escolar, acadêmica e profissional dos professores.

0 relato dos professores deixa transparecer que não chegaram a conhecer a resolução de problemas (como metodologia) durante a formação acadêmica. A fala de P2, na entrevista, comprova essa hipótese, quando afirma, de forma enfática: "Se for pensar nessas coisas, o que me recordo ter visto sobre a resolução de problemas foi só em Física, o resto foi tudo Matemática bruta, sem contextualização, sem nada. Conhecimento pelo conhecimento".

Em consequência disso, percebe-se que os saberes experienciais são os mais mobilizados na prática docente durante uma aula. Esse fato também é comprovado, por exemplo, na descrição feita por P3 (em resposta ao questionário) de como trabalha os problemas e exercícios: "Procuro inserir o aluno como parte ativa do problema, fazendo a leitura junto com ele, fazendo perguntas sobre como resolver e pedindo sugestões". Estratégia semelhante se percebe no professor P4, que afirma no questionário: "Sempre após ensinar a base do assunto, uso resolução de problemas para que os alunos fixem os conteúdos de forma significativa". Percebe-se que eles desenvolveram métodos pessoais para executar suas atividades docentes referentes à resolução de problemas, os quais são oriundos da própria prática, conforme assevera Tardif (2002).

\subsection{FATORES QUE DIFICULTAM O DESENVOLVIMENTO DA RESOLUÇÃO DE PROBLEMAS NA PRÁTICA PEDAGÓGICA DOS PROFESSORES}

Todos os professores da pesquisa deixaram patente que as abordagens ou os conteúdos estudados na academia não lhes deram suporte para ensinar a álgebra escolar mediada pela Resolução de Problemas. Exemplo disso ocorre na seguinte declaração feita pelo informante P4, durante entrevista: "A minha dificuldade já é ensinar aqueles problemas que têm várias operações 'pros' meninos. Acho que é preciso fazer formação continuada, principalmente em matemática".

Dessa forma, constata-se que a abordagem metodológica atribuída ao ensino da álgebra na Licenciatura produz profundas marcas nos futuros professores. Isso também se verifica na fala do professor P2, ao fazer a seguinte afirmação, em entrevista: "Vou ser sincero, não houve mudanças do Ensino Fundamental e Médio para o Superior, eles continuaram com o mesmo ensino tradicional, mostrando coisas que eu não sabia, continuaram usando as mesmas metodologias, e eu tive muitas dificuldades".

Outro aspecto que se revela como fator que dificulta a utilização da Resolução Problemas se refere ao desinteresse dos alunos em trabalhar a matemática dentro de um contexto de resolução de problemas. Aliás, para além disso, os estudantes expressam antipatia pela própria matemática, como se verifica no relato de um dos entrevistados, professor P2: "Vejo na escola de colegas que os alunos não prestam atenção e, assim, o ensino não tem um retorno na aprendizagem do aluno. Os alunos odeiam matemática". Isso decorre, possivelmente, do tratamento metodológico que caracteriza as aulas, o qual, em geral, baseia-se nas técnicas de memorização e repetição.

Outro aspecto que gera dificuldades em abordar o ensino da matemática via resolução de problemas, apontado pelos quatro professores, relaciona-se às más condições de trabalho, dentre as quais se destacam os baixos salários, a sobrecarga de trabalho, o espaço físico e a estrutura escolar inadequados, a escassez de recursos materiais, pedagógicos e tecnológicos.

Observa-se um exemplo dessa situação no relato, colhido em entrevista, do professor P4: "Eu não concordo com os baixos salários que temos, e ainda tirar dinheiro do bolso para comprar materiais. Acho que isso está errado e muito errado". P4 percebe o quanto é injusta a condição salarial e de desvalorização a que os educadores são submetidos, a ponto de ter de financiar os recursos pedagógicos se quiser desenvolver um trabalho melhor, fato que expressa, de forma perversa, uma política de desmonte da educação pública.

Além disso, inclui-se nesse aspecto a (in)existência de ambientes extraclasse, como bibliotecas, laboratórios, entre outros, para atividades práticas, os quais, quando existem, muitas vezes não oferecem condições de funcionamento para que os professores desenvolvam sua prática pedagógica com mais eficácia. Essa preocupação transparece na fala do entrevistado P2: "A escola que estou tem apenas cinco 
computadores funcionando, dos trinta que estão na sala do laboratório. Qual é a possibilidade que tenho de dar uma aula usando, por exemplo, o Geogebra? Isso não é problema só dessa escola, mas da rede".

\section{CONSIDERAÇÕES FINAIS}

Verificou-se que os quatro docentes investigados manifestam concepções equivocadas sobre a metodologia resolução de problemas, devido a um conhecimento teórico limitado, o qual é fruto de sua formação acadêmica. Em seus discursos, afirmam usar a resolução de problemas; porém, na prática isso não se materializa, pois associam a resolução de problemas à contextualização ou à aplicabilidade da matemática, considerando que a metodologia comumente utilizada é aquela indicada no livro didático e a adquirida no decorrer de formação inicial e continuada do professor.

Constatou-se, ainda, que há predominância dos saberes curriculares devido ao uso excessivo do livro didático (abordagem conteudista), no entanto, os saberes experienciais não são desprezados, tendo em vista que os professores desenvolveram formas particulares para ensinar matemática, confundindo tais estratégias com o método da resolução de problemas. Além disso, os docentes pesquisados destacam a formação inicial lacunar e as precárias condições de trabalho como limitadoras da adequada exploração dessa metodologia.

\section{REFERÊNCIAS}

[1] Brasil. Parâmetros Curriculares Nacionais. Matemática. Brasília: MEC/SEF, 1997.

[2] Fiorentini, D.; Miguel, A.; Miorim, M. A. Contribuição para um repensar... a Educação Algébrica elementar. Pro-Posições, v. 4, n.1, p. 78-91, 1993.

[3] Gazire, E. S. Perspectiva da Resolução de Problemas em Educação Matemática. 1988. Dissertação (Mestrado em Educação Matemática) - Instituto de Geociências e Ciências Exatas, Universidade Estadual Paulista Júlio de Mesquita Filho, Rio Claro, Unesp, 1988.

[4] Lüdke, M; André, M. E. D. A. Pesquisa em Educação: abordagens qualitativas. São Paulo: EPU, 1986.

[5] Melo, G. F. A. A Formação Inicial e a Iniciação Científica: investigar e produzir saberes docentes no ensino de álgebra elementar. 2003. Tese (doutorado) - Universidade Estadual de Campinas, Faculdade de Educação - Campinas: Unicamp, 2003.

[6] Pozo, J. I. A Solução de Problemas: aprender a resolver, resolver para aprender. Porto Alegre: Artmed, 1998.

[7] Onuchic, L. R. Ensino-aprendizagem de Matemática através da resolução de problemas. In: Bicudo, M. A. V. (Org.) Pesquisa em Educação Matemática: concepções e perspectivas. São Paulo: Editora UNESP, 1999.

[8] Onuchic, L. R.; Allevato, N. S. G. Novas reflexões sobre o ensino-aprendizagem de Matemática através da resolução de problemas. In: Bicudo, M. A. V.; Borba, M. C. (Org.). Educação Matemática: pesquisa em movimento. São Paulo: Cortez, 2004, p. 212-231.

[9] Polya, G. A Arte de Resolver Problemas: um novo aspecto do método matemático. Trad. Heitor Lisboa de Araújo. Rio de Janeiro: Interciência, 1995.

[10] Santos, M. S. G. Saberes da Prática na Docência do Ensino Superior: análise de sua produção nos cursos de licenciatura da UEMA. 2010. 225 f. Dissertação (Mestrado em Educação) - Universidade Federal do Piauí, Teresina, 2010.

[11] Tardif, M. Saberes Docentes \& Formação Profissional. Petrópolis: Vozes, 2002.

[12] Usiskin, Z. Concepções sobre a álgebra da escola média e utilizações das variáveis. In: Coxford, A. F.; Shulte, A. P. As Ideias da Álgebra. São Paulo: Atual, 1994, p. 9-22. 


\section{Capítulo 9}

Identificação da grandeza área em livro didático do 9o ano do Ensino Fundamental numa perspectiva didática-praxeológica

\section{Edmundo Silva Guerra}

Marcella Claudia Barbosa da Silva

Jorge Henrique Duarte

Resumo: Neste artigo é apresentada uma análise realizada em livro didático de matemática do 9o ano do Ensino Fundamental sobre a grandeza área com suporte das Teorias dos Campos Conceituais, do Jogo de Quadros e Antropológica do Didático. As atividades analisadas foram classificadas como situação de Comparação, Produção ou Medida de área e nessa perspectiva contribuem para a aquisição desse conceito por parte do aluno e no enriquecimento do olhar do professor sobre a grandeza área. Identificamos, porém, poucas atividades que contribuem para a construção significativa do conceito de área como grandeza. Acreditamos que esse estudo permitirá ao educador matemático refletir sobre a didática de ensino do conceito de área e na elaboração de situações significativas em relação a sua aprendizagem por parte do estudante.

Palavras-chave: Grandeza Área; Praxeologia; Didática; Ensino Fundamental. 


\section{INTRODUÇÃO}

Na comunidade de educadores matemáticos muitos debates remetem aos processos de ensinoaprendizagem da Matemática em sala de aula ou fora dela. Aliados a essa discussão destacam-se estudos sobre a importância do livro didático e sua contribuição ao professor que deve encaminhar sequências de ensino na perspectiva de que a aprendizagem possa ser utilizada na vida social do estudante.

Considera-se nesses estudos que os conceitos matemáticos são importantes na vida de todo cidadão e que são expressivos por sua relação interdisciplinar com outras ciências. Essas relações vêm sendo vivenciadas pelos professores de Matemática em sala de aula e de certa forma se vincula a orientação da LDB em seu artigo 26, quando revela a importância dos currículos do ensino fundamental e médio que,

\section{"[...] devem ter uma base nacional comum, a ser complementada, em cada sistema de ensino e estabelecimento escolar, por uma parte diversificada, exigida pelas características regionais e locais da sociedade, da cultura, da economia e da clientela. $\S 1 \stackrel{o}{0}$. Os currículos a que se refere o caput devem abranger, obrigatoriamente, o estudo da língua portuguesa e da matemática, o conhecimento do mundo físico e natural e da realidade social e política, especialmente do Brasil".}

Destacamos dos objetivos gerais dos PCN (p. 48, 1998) para o ensino de Matemática a necessidade de "analisar informações relevantes do ponto de vista do conhecimento e estabelecer o maior número de relações entre elas, fazendo uso do conhecimento matemático para interpretá-las e avaliá-las criticamente." Concordamos com esse objetivo, pois, nos leva a refletir sobre a importância dos conceitos matemáticos e sua interpretação em questões que abordam o cotidiano do cidadão.

Várias pesquisas reforçam a necessidade de conceber os conceitos matemáticos como forma de interação humana e para a construção da cidadania desde os anos iniciais de escolarização do indivíduo. Quando um conceito matemático se alia a outros conhecimentos de forma interdisciplinar promove no estudante sensações ricas e relevantes quanto ao seu papel social em níveis de ensino mais avançados.

Nesse contexto, destacamos a importância do conhecimento sobre a grandeza área e de várias ações encaminhadas pelo professor para que o estudante possa entender e aplicar esse conceito matemático em seu dia-a-dia. Nesse sentido, é fundamental a essa importância de entendimento e aplicação a afirmação de Baltar (1996) de que é possível identificar alguns erros, assim como, hipóteses explicativas das dificuldades no processo de ensino aprendizagem envolvendo o conceito de área.

Portanto, o estudo realizado surgiu a partir de conhecimentos vivenciados nas disciplinas Grandezas e Medidas na Educação Básica e Tópicos Atuais em Didática da Matemática no curso de Especialização em Ensino de Matemática na FACIG, em Igarassu - PE, com uma questão para ser pesquisada: Num livro de matemática do 9o ano, as atividades que abordam o conceito de área podem ser diagnosticadas como tarefa direta ou inversa segundo a TAD (Chevallard, 1999) e classificadas segundo Baltar (1996) em situação de Comparação, Produção e Medida.

\section{FUNDAMENTOS TEÓRICOS}

0 estudo em tela procurou analisar o conceito de área enquanto grandeza na perspectiva da praxeologia didática identificando as formas (ou maneiras) como são sequenciados os conceitos e são apresentados os exercícios, as atividades e desafios.

Procuramos caracterizar as atividades como tarefa inversa ou direta segundo a TAD (Chevallard, 1999) e classificá-las como situação de Produção, de Comparação ou de Medida de Área com base em Baltar (1996). Dessa forma, consideramos a orientação dos Parâmetros Curriculares Nacionais - PCN (Brasil, 1998) para que o professor estimule os alunos a buscar variadas possibilidades de soluções para os problemas, exercícios e atividades desafiadoras apresentadas no estudo de um conceito matemático.

A TAD foi adotada no estudo como aporte teórico principal no sentido de analisar atividades as quais vislumbrassem a grandeza área num livro didático do 9o ano do Ensino Fundamental com auxílio da Teoria dos Campos Conceituais (Vergnaud, 1990) e da Teoria do Jogo de Quadros (Douady, 1989).

Destaque-se, de Gérard \& Roegiers (1998), dois aspectos relevantes aos entraves existentes nos processos de ensino e aprendizagem para alunos na educação básica: a importância do livro didático na relação com o aluno e suas relações com o professor. 
Nesse contexto, temos a praxeologia da TAD como o modelo teórico que sustenta a análise das atividades, as quais são produtos das fases que o conceito de área como objeto do saber matemático percorre. Tivemos como objetivo analisar aspectos da metodologia e da didática do ensino da grandeza em pauta, procurando uma relação com as questões propostas pelo professor com o suporte do Livro Didático e dos parâmetros legais.

Considerando a questão que seria pesquisada constatamos que não estão plenamente evidenciadas e exploradas como tarefa aberta, pois, no texto de uma situação-problema os dados e as incógnitas não estão totalmente pré-fixados.

O estudo de Rossini (2006) que se apoia em Bosch e Chevallard (1999), destaca que a noção de tarefa em Matemática é

"O que distingue a atividade matemática das outras atividades humanas é que, diante de uma tarefa, é preciso saber como resolvê-la. 0 "como resolver a tarefa" é o motor gerador de uma praxeologia: é preciso ter (ou construir) uma técnica, que deve ser justificada por uma tecnologia, a qual, por sua vez, precisa ser justificada por uma teoria (Bosch e Chevallard, p.84, 1999).”.

Para exemplificar uma situação como uma tarefa direta, destacamos: Representar graficamente uma função a partir de sua expressão algébrica. 0 aluno necessita interpretar como é o funcionamento das técnicas e de seus resultados. Para ilustrar uma tarefa inversa temos: Obter a expressão algébrica que representa um gráfico. Neste caso, os dados e as incógnitas não estão totalmente pré-fixados, é uma situação inversa da tarefa direta.

Utilizando a Teoria dos Campos Conceituais (Vergnaud, 1983) o professor promove a aquisição de conhecimento de forma satisfatória. De acordo com o autor é possível ao professor, após muita formação e estudos, observar a ocorrência do erro num determinado percurso conceitual dentre os elencados por ele e consegue partir da teoria para a prática.

Entretanto, é preciso testar e trabalhar sempre as diversas ideias de um conceito com os alunos. Cometer erros e acertos, recomeçar sempre, pressupõe ser para a Didática a chave do conhecimento escolar nesse mundo contemporâneo e de uma disputa de um nível cada vez mais exigente. No entanto, é preciso compreender que cada disciplina possui sua respectiva didática e dentro da possibilidade da Didática da Matemática é fundamental, para o professor de Matemática, tomar consciência das especificidades dessa disciplina e os vários conceitos em particular o conceito de área.

Para ampliar os fundamentos desse trabalho recorremos a Teoria do Jogo de Quadros (Douady, 1996), destacando que a aprendizagem deve ocorrer através da resolução de problemas que envolvam a interação entre pelo menos dois quadros tem suas relações com o trabalho em destaque. Consideramos como quadros conceituais (domínios, segundo Douady, 1983) os ramos da mesma, como a álgebra, a geometria, a combinatória, entre outros.

Nessa linha de pensamento considera-se que um determinado problema que aborda o conceito de área é mais significativo para o aluno quando são mobilizadas representações algébricas, geométricas e numéricas para a grandeza área. Ao considerar os elementos de respostas para avaliar a aprendizagem do aluno e a qualidade do ensino a TAD aparece como uma teoria propícia para auxiliar o professor na identificação desses elementos.

A ideia de contemplar a qualquer tempo a Organização Didática (OD) na resolução de problemas favorece, segundo Chevallard (1989), a orientação para não priorizar apenas a solução das situações propostas, mas, centrar nos meios que permitam chegar a resposta esperada. Neste caso, os procedimentos adotados pelo aluno na resolução de uma situação-problema devem ser estimulados pelo professor a mobilizá-los em outras oportunidades.

Nesse sentido, recomenda-se que a avaliação da aprendizagem seja centrada no estudo dos procedimentos que oportunizem a resolução de situações propostas pelo aluno com apoio nas orientações de Chevallard (1989) e dos PCN (1998).

As praxeologias didáticas respondem, em geral, a questões do tipo: “Como realizar o estudo de determinado assunto, referem-se ao modo que possibilita a realização do estudo de um determinado tema, o conjunto de tipos de tarefas, de técnicas, de tecnologias, etc., mobilizadas para o estudo de um tema." (CHEVALLARD, 1998). Também se referem à estrutura e ao desenvolvimento do trabalho de certo conceito ou conteúdo ou ainda, o modo que possibilita a realização de um determinado conceito, técnica, 
tecnologia, no estudo de um conceito, são o caminho para estabelecer uma Organização Matemática (OM), melhor e mais adequada escolha, nas questões do tipo: Como realizar determinado conceito matemático?

Para Chevallard, Bosch e Gascón (2001, p. 251) na atividade matemática, como em qualquer outra atividade, existem duas partes que não podem viver uma sem a outra, pois, de um lado estão as tarefas e as técnicas e, de outro, as tecnologias e teorias.

Chevallard propôs, em sua teoria, seis momentos os quais, sem o rigor da devida ordem proposta, podem revelar, por meio de possibilidades de apresentação e avaliação, a eficiência ou não, por exemplo, do Contrato Didático (CD). Posposto a isso, poderá revelar em qual momento houve uma quebra (ou ruptura) no processo, em que o professor pode retomar a sequencia no momento do erro até que se alcance o objetivo.

Alguns estudos evidenciam o erro como alguma coisa que não está relacionada a algo negativo. Dois momentos são descritos por Teles (2004), um deles nos faz remeter a uma reflexão sobre as dificuldades dos alunos na aprendizagem da álgebra oferecendo subsídios para estudo sobre a relação aritméticaálgebra nos seus aspectos de ruptura e continuidades, pois acreditamos que seja uma possível consequência para que o aluno também tenha dificuldades no ensino-aprendizagem do conceito de área. 0 outro momento nos traz uma reflexão sobre a influência do campo algébrico na resolução de situações que envolvem fórmulas de área em que são discutidos os procedimentos corretos ou não, feitos pelos alunos, em questões extraídas de livros didáticos de matemática.

\section{A SEQUÊNCIA QUE ABORDA A GRANDEZA ÁREA}

A BCC-PE ${ }^{13}$ (2008) divide as competências e saberes dos conceitos matemáticos em dois períodos distintos do ensino fundamental: um para a primeira etapa (séries iniciais) e outro para a segunda etapa (séries finais) do Ensino Fundamental. Na primeira, a criança traz consigo um conjunto de saberes matemáticos construídos em interação com seu meio social. A segunda, na qual se vincula o livro didático analisado, pode ser tratada como uma continuação da etapa anterior e deve ser vista como avanço, ampliação e consolidação das aprendizagens realizadas anteriormente.

A grandeza área está presente na história da humanidade bem como em várias culturas. Também, naturalmente, obtém sua importância na relação com os vários setores da sociedade, nos quais são realizadas varias atividades envolvendo essa grandeza. Por sua vez, o seu estudo, investido na educação básica, é reconhecido nas orientações curriculares nacionais para o ensino fundamental e pela indicação das grandezas e medidas como um dos quatro domínios da matemática escolar (BRASIL, 1997; 1998).

Segundo Vergnaud (1986), o conhecimento emerge na resolução de problemas e a partir da ação do sujeito sobre a situação que precisa ser resolvida, seja de caráter teórico ou prático, esta ação precisa de uma reflexão para que não se torne apenas uma competência adquirida, mas sim, que se encaminhe na direção da formação. Assim poderá ser estabelecida uma competência de um determinado saber.

Fig. 1 -

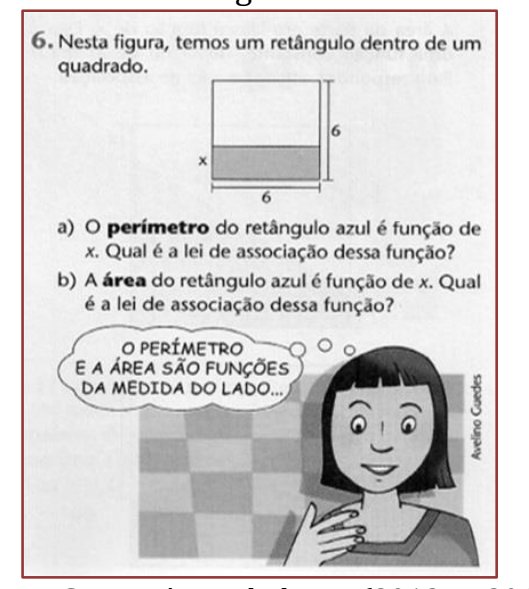

Fonte: Centurión e Jakubovic (2012, p. 201)

${ }^{13}$ Base Curricular Comum para as Redes Públicas de Ensino de Pernambuco 
A atividade ilustrada na figura acima destaca a interação entre os conceitos de perímetro e área (do quadro das grandezas), referentes a um retângulo dentro de um quadrado (quadro geométrico), as medidas de comprimento indicadas x (incógnita) e 6 (u.c.) são os lados do retângulo e 6 (u.c.) do quadrado (são conceitos do quadro numérico) e as leis de formação correspondentes (quadro da álgebra e das funções) segundo a Teoria do Jogo de Quadros (Douady, 1983).Observamos na figura acima a relação entre a área e o perímetro de um retângulo dentro do quadrado em função do lado x. Para resolver a questão com o suporte da TAD identificamos a atividade como exemplo de duas tarefas diretas (Td).

A técnica $(\mathrm{t})$ a ser utilizada para resolver cada tarefa requer o conhecimento sobre as fórmulas do perímetro e da área de um retângulo, respectivamente, sendo apoiada pela teoria que trata dos conceitos de perímetro (comprimento do contorno) e área (superfície) de uma figura plana. Para representar a lei de formação do perímetro e da área do retângulo, em função do lado x, é necessário se apoiar nos conceitos de perpendicularismo, paralelismo e congruência entre os lados $x$ e 6 , obtendo $x+x+6+6=2 x+12$ para o perímetro e x.6 para a área do retângulo.

Ainda sobre o livro pesquisado, o levantamento quantitativo revelou a apresentação, a conceituação e a exemplificação de uma proposta total de 67 atividades, da página 158 a 177, e como foi elaborada pelos autores a organização didática envolvendo a grandeza área para ser apresentada ao aluno.

Levamos também em consideração os Parâmetros Curriculares Nacionais (PCN, 1998, p. 44 e p. 48) e interpretamos que os autores apresentam diversos exemplos do cotidiano que trazem o termo área bem como a sua interdisciplinaridade e contextualização com outras ciências. 0 quantitativo de atividades com os respectivos percentuais é mostrado no quadro abaixo, destacando a grandeza área e dessas quais são as atividades classificadas segundo DUARTE (2010) que se apoiou em Baltar (1996) em situações de Medida, Comparação e Produção de Áreas.

Gráfico 1. Classe de situação segundo Baltar (1996)

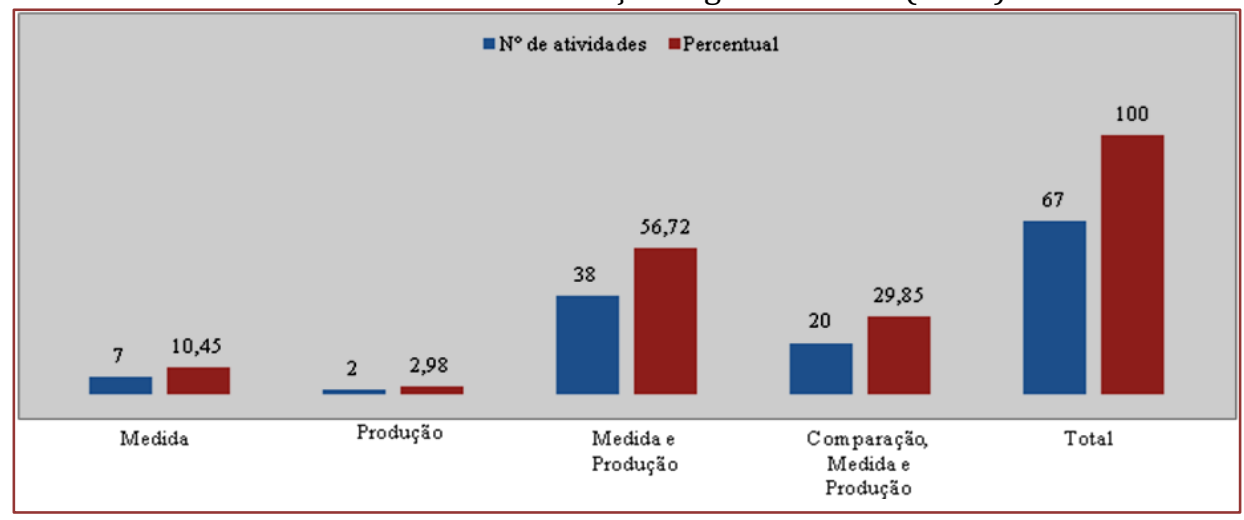

São exemplificadas abaixo quatro atividades do livro didático de CENTURIÓN e JAKUBOVICK (2012) com destaque para a Tarefa direta (Td) e a Tarefa inversa (Ti) segundo a TAD (Chevallard, 1998) e para contextualizar em classes de situação segundo Baltar (1996) envolvendo a grandeza área: produção, medida e comparação.

Fig. 2 (pág. 174)

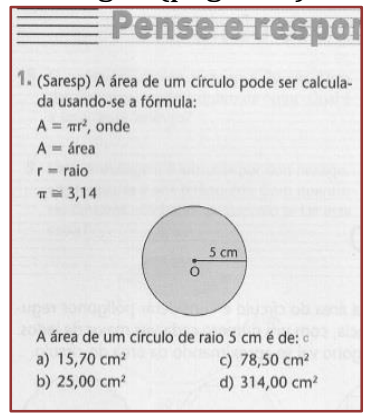

Fig. 3 (pág. 159)

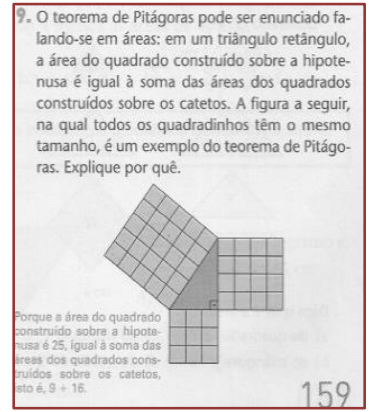

Fig. 4 (pág. 172)

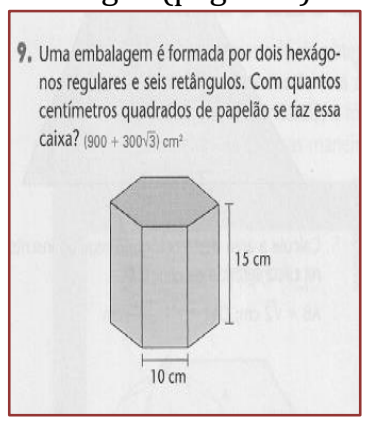

Fig. 5 (pág. 175)

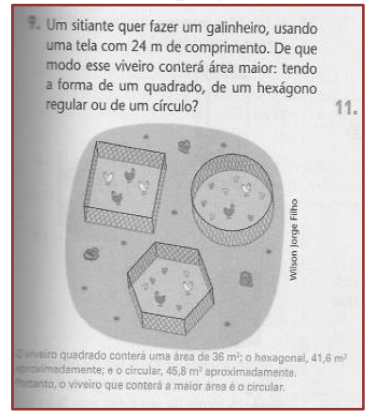


Em relação às figuras acima, poderemos tecer alguns comentários, que são relevantes à pesquisa destacando as técnicas esperadas para resolução.

A figura 2 ilustra uma Tarefa Direta em que o aluno necessita associar os dados fornecidos (significado dos termos A e $r$, e o valor de $\pi=3,14$ ) com a fórmula para calcular a área de um círculo cujo raio mede $5 \mathrm{~cm}$. A técnica esperada é substituir a medida do raio e o valor de $\pi$ na fórmula $\pi . r^{2}$; efetuar a potenciação em $r$; em seguida a multiplicação por $\pi$ e obter a resposta que é 78,5 $\mathrm{cm}^{2}$ (alternativa c).

Quanto à figura 3, consideramos um bom exemplo para o aluno entender o significado do Teorema de Pitágoras em termos do conceito de área. Caracterizamos como Tarefa Direta, pois a técnica esperada é a contagem dos quadrados unitários que representam as medidas das áreas dos quadrados $(9,16$ e 25) desenhados sobre os lados do triângulo retângulo ou usar a fórmula de área de um quadrado (lado x lado) obtendo $3 \times 3,4 \times 4$, $5 \times 5$ e aplicando posteriormente a fórmula do Teorema de Pitágoras e obtendo a relação $3 \times 3+4 \times 4=5 \times 5, \log 0,9+16=25$.

A figura 4 é outro exemplo de Tarefa Direta e para sua resolução é necessário identificar os dados fornecidos para a embalagem (prisma de base hexagonal) formada por seis faces retangulares, suas medidas $(15 \mathrm{~cm}$ e $10 \mathrm{~cm}$ ) e associar com a planificação adequada não esquecendo os dois hexágonos (superior e inferior). Para resolver é necessário recorrer às fórmulas das áreas de um hexágono (que depende da fórmula de um triângulo equilátero, b.h/2) e de um retângulo (b.h) e somar de acordo com a sentença 2.Ahex + 6.Aret, obtendo a medida de área em $\mathrm{cm}^{2}$ de papelão a ser usado para fazer a embalagem.

Na figura 5 temos outra Tarefa Direta. Apresenta três figuras (um quadrado, um hexágono e um círculo) e uma medida de comprimento. Para encontrar a resposta é necessário utilizar a técnica seguinte: usar inicialmente as fórmulas do perímetro de cada figura, calcular o elemento da figura que auxiliará no cálculo da medida das áreas correspondentes a cada figura e depois comparar as medidas dessas áreas. 0 procedimento de comparar as medidas das áreas decidirá a reposta esperada.

No decorrer da apresentação do conceito de área pelo Livro Didático analisado, foi verificado, por meio de levantamento da pesquisa que a parte formal das figuras geométricas planas é mais explorada do que a grandeza área de cada uma das figuras geométricas citadas nas páginas 158, Área do retângulo e área do quadrado, página 161, Área do paralelogramo e área do triangulo, página 167, Área de outros polígonos, e página 173, Área do círculo, de acordo com o Capítulo 6. Na página 158, encontra-se a construção das áreas do retângulo e do quadrado inicialmente no conceito formal e depois a utilização das respectivas figuras com a definição algébrica generalizada para as duas figuras. Nos dois exemplos contidos nessa página, tratamos de ilustrar a tarefa direta.

Na apresentação do conceito da área do paralelogramo, página 161, os autores utilizam quatro figuras (paralelogramos) com suas respectivas medidas algébricas, em uma ilustração na qual consideramos como conceito informal, para depois se formalizar o respectivo conceito, sendo encontrada apenas uma exemplificação de Tarefa Direta. Na página seguinte, os autores utilizaram a construção de um paralelogramo para definir a área do triangulo de maneira informal e, a partir daí, construíram a definição formal e a apresentação de sua forma algébrica.

Contudo, acreditamos que o estudante deve aprender sobre várias possibilidades de se encontrar a área das figuras geométricas planas e que é possível encontrar á área de um triângulo por meio de algumas outras figuras.

Consideramos ainda que o professor tem um papel de suma importância na descoberta dos conceitos desenvolvidos pelos alunos. Dos três exemplos verificados nessa página foi detectada apenas a exemplificação de Tarefa Direta.

Na página 167, os autores demonstram que é possível calcular a área de alguns polígonos fazendo o uso de triângulos. Para a demonstração, os autores utilizaram dois trapézios, sendo um retângulo e o outro não, de tal modo que a definição do conceito é dada de forma escrita (formal) e que o único exemplo se dá por uma tarefa direta. Definindo a área do losango na página 168 os autores fazem uso do mesmo raciocínio mencionado na página anterior. Partindo desses requisitos utilizados pelos autores, acreditamos que o professor precisa trabalhar muito bem em sala aula a construção de uma figura a partir de outra.

Nessa página são construídos dois triângulos semelhantes a partir de um trapézio, para o qual os autores chegam a uma definição algébrica para depois formalizar uma definição informal. Os autores usaram o mesmo procedimento para se obter a área do trapézio na formação da definição da área do losango. 
Na página 169, os autores constroem o conceito da área dos polígonos regulares fazendo o uso da figura de um pentágono regular. 0 pentágono foi dividido em cinco triângulos e a partir daí foi construída o conceito da área de um polígono regular de maneira formal e informal. Para contextualizar, de maneira escrita, algébrica, formal e direta, através desses polígonos, o conceito da área do círculo, foi feita a observação de que aumentando o número de lados, mais a área do polígono se aproxima da área do círculo e, consequentemente, o perímetro do polígono se aproxima do comprimento da circunferência.

Fig. 6 (Atividade da pág. 159).

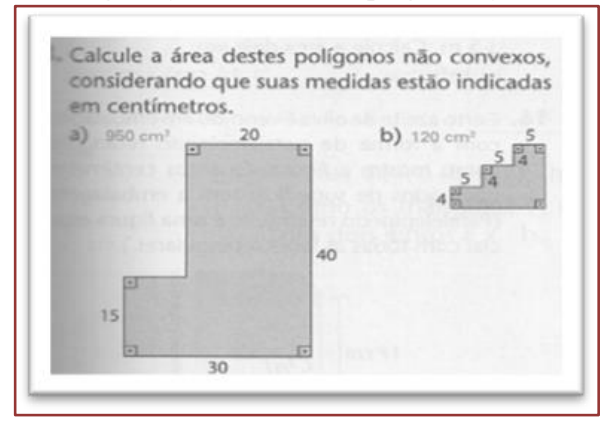

Fig.7 (Atividade da pág. 160).

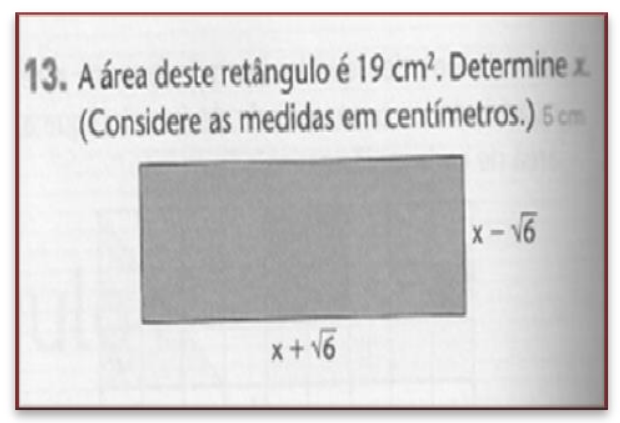

Os exemplos acima apresentam tipos de Tarefas Diretas, com base na TAD, em que, na atividade a) da figura 6 é necessário observar a existência de, pelo menos, dois retângulos; e, na atividade b) a existência de pelo menos 3 figuras retangulares. Entretanto, em quaisquer dessas duas atividades, será preciso avaliar qual(is) procedimento(s) devem ser usados para resolver as atividades. Na figura 7 é apresentada uma tarefa envolvendo um retângulo com os lados expressos algebricamente. Essa atividade é caracterizada como classe de medida de área de uma tarefa direta, em que o aluno precisa ter o conhecimento da operação multiplicação de expressões algébricas para obter o valor de "x".

O capítulo 6, norte específico para o estudo do livro didático do 9o ano do ensino fundamental (Centurión e Jakubovic, 2012), trata das fórmulas de alguns polígonos convexos e do círculo e traz para o aluno uma perspectiva de ampliação de conhecimento das figuras geométricas planas, uma perspectiva de conhecimento sobre medidas úteis no cotidiano, bem como uma perspectiva para ampliar o conhecimento da Grandeza Área com o suporte de conceitos básicos da geometria, a qual será estudada com mais conteúdos e dinamismo no Ensino Médio.

\section{CONSIDERAÇÕES FINAIS}

Sobre os momentos refletidos nesse trabalho acreditamos que contribuirá no enriquecimento do olhar do professor a respeito das atividades analisadas. Com base nos dados levantados consideramos que o estudo da grandeza área foi desenvolvido com prioridade para situações de medida. Eventualmente o autor propõe atividades que necessitam da produção. Destacamos que a comparação de medidas de áreas aparece com menos frequência do que as situações de produção. As atividades classificadas como situações de "Medida e Produção de Área", com 38 atividades representam 56,72\% do total.

Acreditamos que a medida em sua essência numérica requer a prévia existência de conhecimento de formas geométricas bem como alguns conceitos de fórmulas para resolver as atividades relacionadas à grandeza em estudo.

$\mathrm{Na}$ pesquisa identificamos a ausência de estímulos antecedentes (conceitos anteriores) ao conceito da grandeza área os quais pudessem levar o aluno a resolver as atividades propostas. Na maioria das vezes os conceitos eram consolidados, pelo livro, de maneira formal, seguidos de exemplos e exercícios que, possivelmente, podem criar um "comodismo" no estudante. Sugerimos que é importante, inicialmente estimular o estudante por meio de desafios, depois apresentar o conceito em seu estado informal e em seguida promover sua apresentação de forma usual ou formal.

Embora seja um recurso indispensável ao professor e ao estudante, é difícil definir o Livro Didático (LD) quanto à função que exerce ou deveria exercer dentro e fora da sala de aula. Para Gérard e Roegiers (1998, p.19), o livro didático é um instrumento impresso, intencionalmente estruturado para se inscrever num processo de aprendizagem, com o fim de lhe melhorar a eficácia. Contudo, acreditamos também que o LD, 
de acordo com as condições, lugares e situações adversas em que é produzido e utilizado assume uma importância diferenciada.

Por fim, acreditamos que esse trabalho permitirá uma reflexão mais abrangente sobre a exposição do conceito da grandeza área e na elaboração de novas técnicas e situações didáticas mais eficientes em relação ao ensino aprendizagem do conceito em pauta cabendo ao professor de matemática buscar novas leituras que o ajude a vivenciar práticas didática mais significativas, selecionando atividades de livros didáticos apoiadas em fundamentos teóricos que justifiquem a sua prática de ensino.

\section{REFERÊNCIAS}

[1] Barbosa, E. J. T.; Lins, A. F. Teoria antropológica do didático: uma análise sobre equação do primeiro grau em livros didáticos. In: Enem, X, 2010, Salvador. Disponível em: <http://www.lematec.net/CDS/ENEM10/artigos/CC/T4_CC35.pdf>. Acesso em: 29 jul. 2015.

[2] Brasil. MEC. LDB - Leis de diretrizes e Bases<http://portal.mec.gov.br/setec/arquivos/pdf1/proejalei9394.pdf.>. Acesso em 03 mar. 2016.

[3] Brasil. MEC. SEF. PCN - Parâmetros Curriculares Nacionais. 1997.<http://portal.mec.gov.br/seb/arquivos/pdf/livro03.pdf>. Acesso em 03 mar. 2016.

[4] Brasil. MEC. SEF. PCN - Parâmetros Curriculares $\quad$ Nacionais. 1998. <http://portal.mec.gov.br/seb/arquivos/pdf/livro03.pdf>. Acesso em 03 mar. 2016.

[5] Centurión, M.; Jakubovic, J. Matemática: teoria e contexto, 9o ano, ensino fundamental: livro do professor. São Paulo: Saraiva, p.260, 2012.

[6] Duarte, J. H.; Um estudo sobre a compreensão de problemas de matemática envolvendo grandezas perímetro e área, álgebra e funções no ensino médio. In: Enem, IX, 2007, Minas gerais. Disponível em: <www.sbembrasil.org.br/files/ix_enem/.../CC17227801420R.doc>. Acesso em: 02 mar. 2016.

[7] Gérard, F.-M, Roegiers, X. (1993) - Concevoir et évaluer des manuels scolaires. Bruxelas. De Boeck-Wesmail (tradução Portuguesa de Júlia Ferreira e de Helena Peralta, Porto: 1998).

[8] Rossini, R.A contribuição da teoria antropológica do didático para a análise de livros didáticos de matemática. In: Educere, VI, Paraná, 2006. <http://www.pucpr.br/eventos/educere/educere2006/anaisEvento/docs/CI-155-TC.pdf>. Acesso em 02 fev. 2016.

[9] Teles, R. A. M. A Aritmética e a Álgebra na Matemática Escolar. Educação Matemática em Revista. VIII Enem, 2004. Disponível em <http://www.sbem.com.br/files/viii/pdf/02/ MC58937242400.pdf >. Acesso em 25 fev. 2016

[10] Teles, R. A. M. Um estudo sobre a influência do campo algébrico na resolução de situações que envolvem fórmulas de área. Educação Matemática em Revista. Educação Matemática Pesquisa (Online), v.12, p. 1 - 14, 2010. Disponível em <http://revistas.pucsp.br/index.php/emp/article/ view/2377>. Acesso em 25 fev. 2016

[11] Vergnaud, G. Teoria dos campos conceituais. In Nasser, L. (Ed.) Anais do 1o Seminário Internacional de Educação Matemática do Rio de Janeiro. p. 1-26, 1993. 


\section{Capítulo 10}

\section{Origami: O uso como instrumento alternativo no}

ensino da geometria.

\section{Aline Claro de Freitas Abucarma \\ José Roberto Nogueira}

Resumo: Frente à realidade do ensino contemporâneo que demanda a necessidade de diversificar o uso de estratégias de ensino, pretendemos propor uma abordagem, por meio de material concreto e que pode tornar-se bastante significativa no ensino da matemática. Este trabalho discute sobre a história, aplicações clássicas e utilização do origami em sala de aula. Após uma breve apresentação histórica sobre o origami, apresentamos uma abordagem axiomática deste instrumento. Dois dos três famosos problemas matemáticos gregos da antiguidade que não podem ser solucionados através da régua e compasso: trissecção do ângulo e duplicação do cubo encontram uma solução por meio das técnicas de origami. Além disso, apresentamos sugestões de roteiros de aulas e a atividade aplicada em sala de aula que obteve resultado satisfatório.

Palavras-chave: aprendizagem; geometria; origami; trissecção; axioma. 


\section{INTRODUÇÃO}

0 ensino de matemática tem se tornado um verdadeiro desafio. No cotidiano escolar verifica-se o baixo rendimento na disciplina e as avaliações externas comprovam o despreparo dos alunos. Requer-se a diversificação de metodologias na prática docente, projetando um cenário mais atraente e motivador ao aluno e tornando possível o desenvolvimento de habilidades e competências. Neste contexto é que uma nova abordagem da geometria pode ser de grande valia. Aqui será proposto um recurso alternativo com o intuito de trazer significado não só à geometria, mas à matemática como um todo: o origami.

Em verdade, por muito tempo o ensino da geometria desempenhou, tão somente, um papel secundário no ensino da matemática. Seu resgate poderá minimizar as deficiências encontradas e o uso do origami, neste sentido, se mostrar bastante profícuo. Aliás, é sabido que a utilização de recursos concretos e lúdicos no ensino da matemática pode trazer ganhos na significação dos conteúdos, permitindo que o aluno faça a apropriação do conhecimento e tenha uma aprendizagem mais eficaz. Apesar de ser uma técnica conhecida há mais de dois milênios, é pouco difundida como recurso metodológico de ensino. No Brasil é também chamada de dobradura e usualmente tratada apenas como forma de arte ou diversão. Como bem pontuou Robert J. Lang (2010), as figuras de origami possuem uma beleza estética que agrada tanto ao matemático como o leigo. Parte do seu apelo é a simplicidade do conceito, onde é possível fazer desde construções pouco elaboradas até as mais complexas por meio da definição de uma sequência de dobragem.

Este campo é rico e variado, com conexões nos diversos campos da matemática como: divisão binária, construção de frações ou proporções racionais, determinação de frações irracionais, construções geométricas diversas, entre outras. Estimular a inserção dessa metodologia, ainda pouco utilizada nos processos de ensino certamente concorrerá para o aprimoramento do ensino da matemática.

\section{CONTEXTO HISTÓRICO DO ORIGAMI}

Acredita-se que o origami seja criação japonesa. Apesar de o papel ter sido desenvolvido na China, os origamis mais antigos encontrados datam do século VI d.C., mesmo período em que o papel chegou ao Japão, trazido pelos monges budistas. Ademais, a própria palavra "origami" deriva de duas palavras japonesas. A expressão Ori significa dobrar e Kami possui dois significados: papel e deus. Ori e Kami formam assim a palavra origami que designa precisamente a arte de criar figuras diversas utilizando-se apenas papéis e dobraduras, sem cortá-los ou colá-los. (FREITAS, 2013)

Inicialmente, a arte foi dominada pelos nobres em razão do custo elevado da matéria prima. De fato, o papel era tido como artigo de luxo e o origami utilizado para adornar cerimoniais religiosos. Após o papel tornar-se mais popular, a técnica se difundiu e já em 1876 integrava o currículo escolar japonês. 0 origami passou a compor parte relevante na cultura japonesa. Era possível reconhecer as diferentes classes sociais e profissões, por exemplo, a partir da constatação de quais dobraduras os indivíduos possuíam. A disseminação da técnica culminou por aperfeiçoá-la e sua prática alcançou o mundo. No Brasil ocorreu mais tardiamente e era privilégio das famílias portuguesas mais abastadas.

O origami ganhou ainda mais notoriedade com a lenda do pássaro grou, ave sagrada no Japão. A lenda dizia que o pássaro viveria mil anos e qualquer pessoa que dobrasse mil pássaros de papel teria seu desejo atendido. Uma menina, chamada Sadako, sofria com sequelas deixadas pela bomba atômica de Hiroshima, e ao conhecer essa lenda, iniciou sua jornada na esperança de sobreviver, mas acabou falecendo antes de completar os mil pássaros. Sua obstinação inspirou milhares de crianças a arrecadarem dinheiro para erigir um monumento em sua homenagem. Num gesto de protesto e de apelo pela paz mundial, foram gravadas as seguintes palavras: "Este é o nosso grito. Esta é a nossa prece. Construir a paz no mundo que é nosso". (OLIVEIRA, 2004). 0 Tsuru (pássaro grou) se consubstanciou em um símbolo da paz, a prática do origami adquiriu no Japão uma conotação muito mais artística e filosófica do que científica. 0 alemão Friedrich Froebel foi o pioneiro em desenvolver um método pedagógico. Posteriormente, o inglês Arthur H. Stone registrou os flexágonos como exemplo de aplicação do origami, permitindo de forma recreativa verificar conceitos matemáticos. Na formalização desta técnica Humiaki Huzita e Koshiro Hatori destacaram-se nos estudos que enumeravam as possíveis dobragens em origami e as combinações entre elas sendo esta a primeira descrição formal. 


\section{AXIOMAS DE HUZITA HATORI}

Humiaki Huzita se destacou quando apresentou seis operações para definir uma dobragem com um único vinco que, por si só, alinha várias combinações de pontos e retas já existentes. Estas operações ficaram conhecidas como axiomas de Huzita e fornecem a primeira descrição formal para as construções geométricas por origami. Anos mais tarde, em 2002, Koshiro Hatori apresentou uma sétima dobragem que completa a lista dos sete axiomas de Huzita-Hatori. Os axiomas de Huzita-Hatori, retirados de Cavacami e Furuya (2010), são os descritos a seguir:

Axioma 1: Dados dois pontos, $P_{1}$ e $P_{2}$, existe apenas uma dobra que passa por eles.

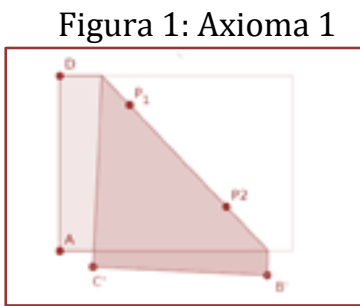

Fonte: CAVACAMI e FURUYA, 2010, p. 3

Axioma 2: Dados dois pontos, $P_{1}$ e $P_{2}$, há uma dobragem que os torna coincidentes.

Figura 2: Axioma 2

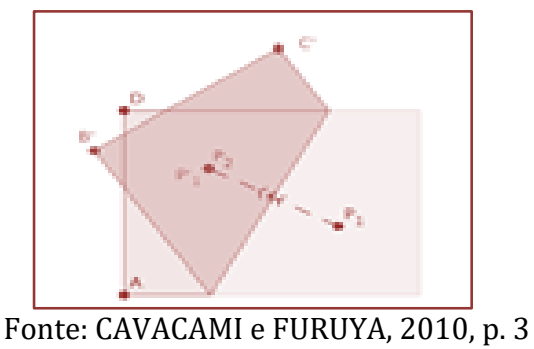

Axioma 3: Dadas duas retas, $r_{1}$ e $r_{2}$, há uma dobra que as torna coincidentes.

Figura 3: Axioma 3

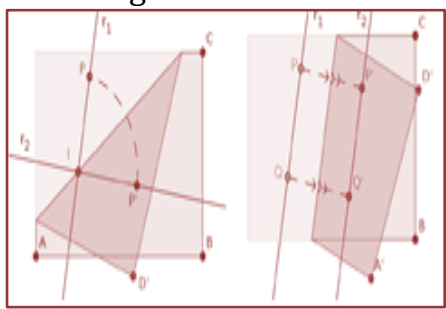

Fonte: CAVACAMI e FURUYA, 2010, p. 4

Axioma 4: Dados um ponto $\mathrm{P}$ e uma reta $r$, há uma dobra perpendicular a $r$ que passa por P.

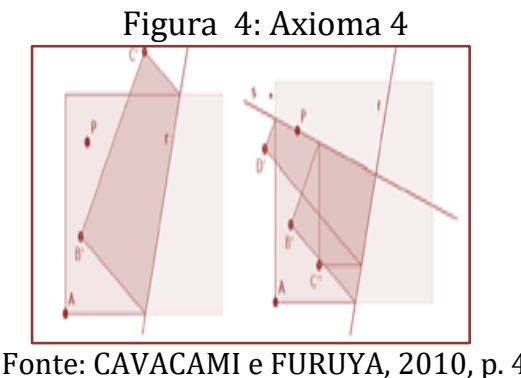


Axioma 5: Dados dois pontos, $P_{1}$ e $P_{2}$, e uma reta $r_{1}$, se a distância de $P_{1}$ a $P_{2}$ for igual ou superior à distância de $P_{2}$ a $r_{1}$, há uma dobra que faz incidir $P_{1}$ em $r_{1}$ e que passa por $P_{2}$.

Figura 5: Axioma 5

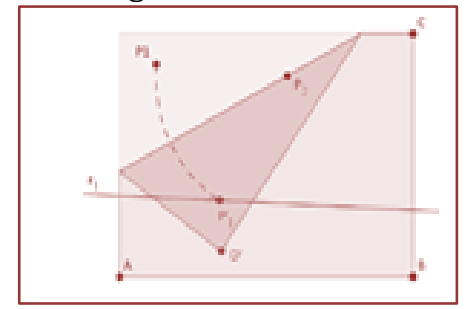

Fonte: CAVACAMI e FURUYA, 2010, p. 4

Axioma 6: Dados dois pontos, $P_{1}$ e $P_{2}$, e duas retas, $r_{1}$ e $r_{2}$, se as retas não forem paralelas e se a distância entre as retas não for superior à distância entre os pontos, há uma dobragem que faz incidir $P_{1}$ em $r_{1}$ e $P_{2}$ em $r_{2}$.

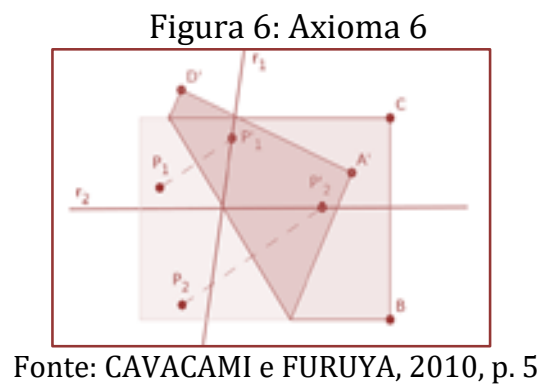

Axioma 7: Dado um ponto, $P$, e duas retas, $r_{1}$ e $r_{2}$, se as retas não forem paralelas, há uma dobragem que faz incidir $P$ em $r_{1}$ e é perpendicular a $r_{2}$.

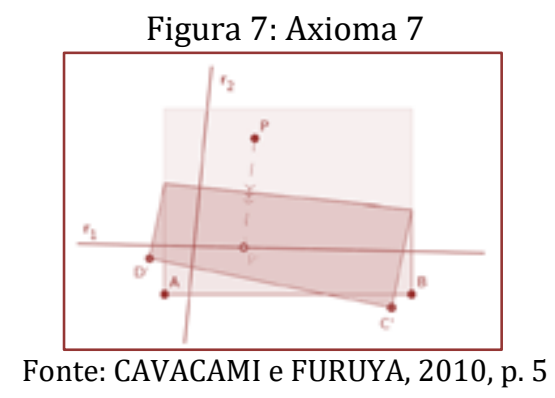

\section{PROBLEMAS CLÁSSICOS DA ANTIGUIDADE GREGA.}

Três importantes problemas são conhecidos como "Os três problemas clássicos da antiguidade grega". Segundo Howard Eves (2011), a importância destes problemas é que não podem ser resolvidos, a não ser aproximadamente, com régua e compasso não marcados, embora sirvam para a resolução de muitos outros problemas de construção. Além disso, a busca pela solução destes problemas possibilitou inúmeras descobertas matemáticas em diversas áreas como: as secções cônicas, muitas curvas cúbicas e quárticas e várias curvas transcendentes, o desenvolvimento de partes da teoria das equações ligadas a domínios de racionalidade, números algébricos e teoria de grupos. Apresentaremos aqui dois dos três problemas, sendo estes possíveis de serem solucionados através do Origami

\subsection{TRISSECÇ̃̃O DO ÂNGULO.}

0 problema de dividir um ângulo arbitrário em $n$ partes iguais era de grande interesse dos gregos, pois através deste recurso poderia ser construído um polígono regular de $n$ lados. Tal problema pode ser solucionado através do origami. Utilizando uma folha de papel quadrada de dimensão qualquer, 
apresentamos um método para trisseccionar um ângulo agudo. Para encontrar a trissecção, basta seguir a rotina da Figura 5.1:

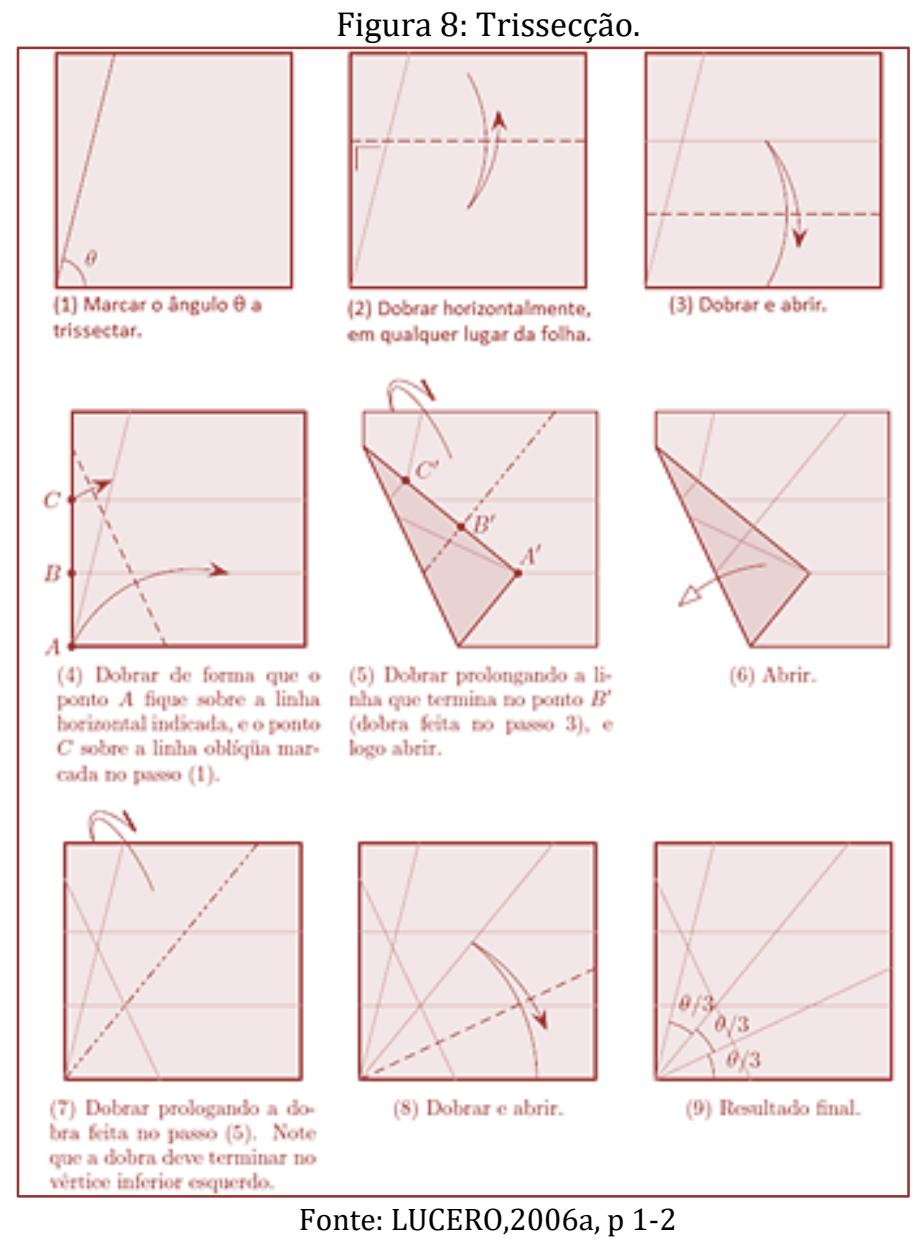

0 passo que não pode ser realizado pela régua e compasso é o de item 4 que é dado pelo axioma 6 de Huzita.

Demonstração: Na figura abaixo foi reproduzida o resultado final juntamente com a dobra do passo (4).

Figura 9: Demonstração trissecção.

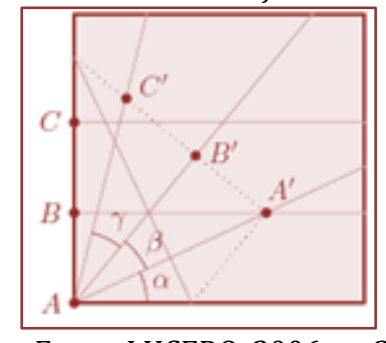

Fonte: LUCERO, 2006a, p.2

Queremos mostrar que $\alpha=\beta=\gamma$. Da dobradura (8) sabemos que $\alpha=\beta$. Além disso, os triângulos $A B^{\prime} A^{\prime}$ e $A B^{\prime} C^{\prime}$ são congruentes. De fato: Como $A B=B C$ da dobra (3) resulta que $B^{\prime} A^{\prime}=B^{\prime} C^{\prime}$; da dobra (5) temos que $A B^{\prime}$ é perpendicular a $A C^{\prime}$. Assim, temos que $\beta=\gamma$ 


\subsection{DUPLICAÇÃO DO CUBO}

O segundo problema que também não é possível de ser solucionado com régua e compasso não marcados, mas possível através das técnicas do origami é a duplicação do cubo.

Conta Eratóstenes que, certa vez na antiga Grécia, os habitantes da ilha de Delos perguntaram ao oráculo de Apolo o que fazer para combater uma peste que assolava o povo. A resposta do oráculo foi que o altar de Apolo, de forma cúbica, devia ser duplicado. Assim, teria nascido o problema geométrico da duplicação do cubo, também conhecido como "problema deliano, que se tornou um dos problemas clássicos da Antiguidade." (BOYCE, 1996; HEATH 1981 apud LUCERO, 2006, p.1).

Figura 10: Procedimento duplicação do cubo.

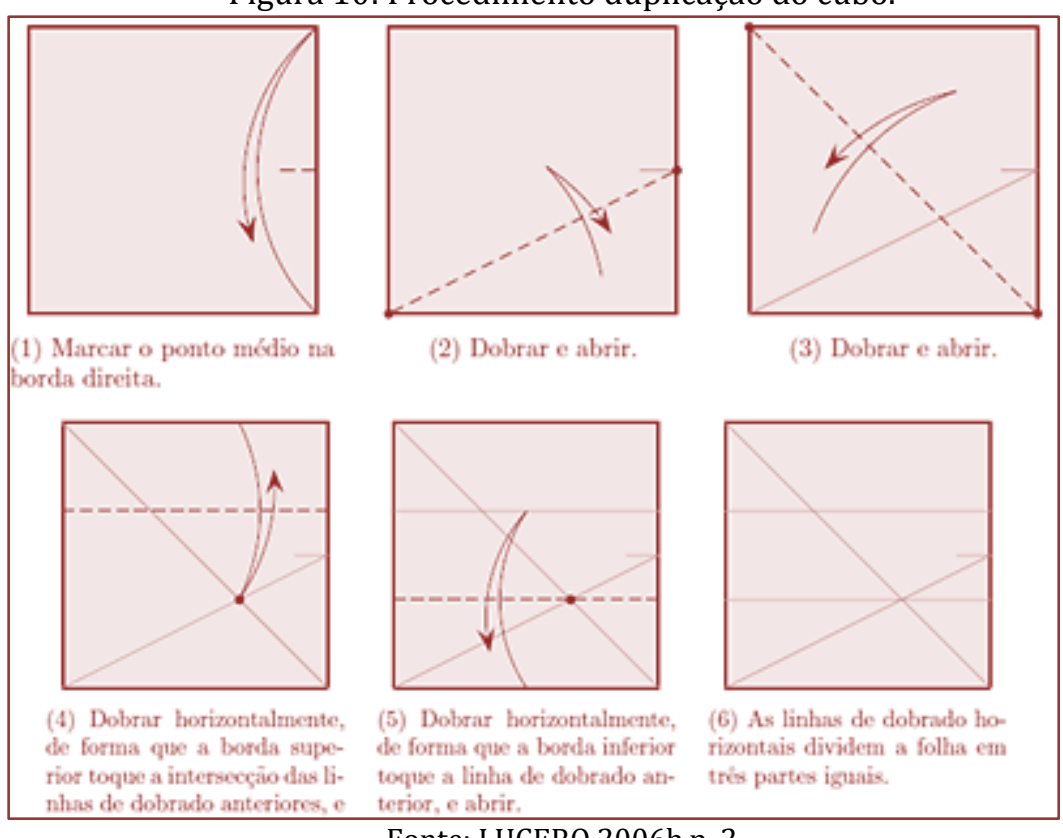

Fonte: LUCERO,2006b,p. 2

Algumas linhas da dobradura não relevantes foram eliminadas, e finalmente encontramos $\sqrt[3]{2}$.

Figura 11 : Passos (7) e (8) duplicação do cubo.

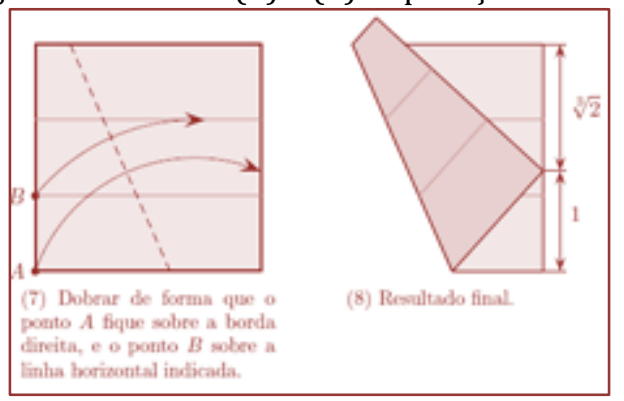

Fonte: LUCERO,2006b,p. 2

Demonstração:A demonstração está de acordo com Lucero (pag 3, 2006 ). Os passos de (1) a (6), dividem o quadrado em três partes iguais. 
Figura 12: Demonstração duplicação do cubo - parte 1.

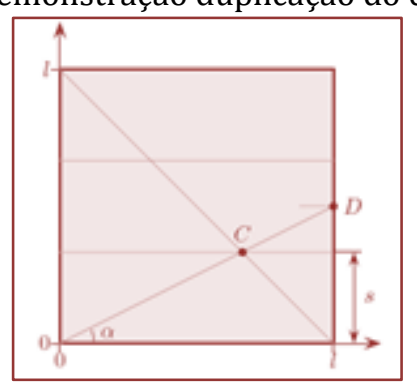

Fonte: LUCERO,2006b,p. 3

De fato: tome a folha com comprimento $l$, e insira um eixo coordenado $(x, y)$, no canto inferior esquerdo da figura. 0 ponto $C$ está à mesma distância da borda inferior e da borda direita, tomemos como $S$ esta distância. As coordenadas dos pontos são: $C=\left(x_{C}, y_{C}\right)=(l-s, s)$ e $D=\left(x_{D}, y_{D}\right)=\left(l, \frac{l}{2}\right)$. Considerando C: $\tan \alpha=\frac{s}{l-s}$. Considerando D: $\tan \alpha=\frac{l / 2}{l}$. Assim: $\frac{s}{l-s}=\frac{l / 2}{l} \Rightarrow l=\frac{1}{3}$. Pelos passos (4) e (5) as linhas horizontais tem a distância de $\frac{l}{3}$ entre si. Observe agora a figura:

Figura 13: Demonstração do cubo - parte 2.

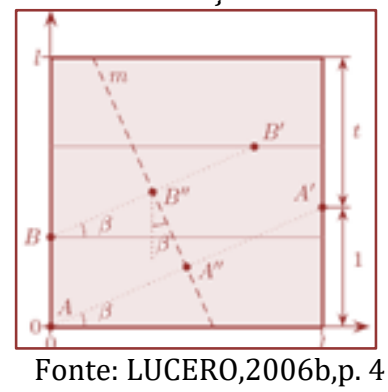

De acordo com os passos (7) e (8) podemos determinar as seguintes coordenadas: $A=(0,0) ; B=$ $\left(0, \frac{l}{3}\right) ; A^{\prime}=(l, 1) ; B^{\prime}=\left(a, \frac{2 l}{3}\right)$; sendo a abcissa do ponto $B^{\prime}$. A partir também da dobra (7), temos que $A^{\prime \prime}$ e $B^{\prime \prime}$ são os pontos médios dos segmentos $A A^{\prime}$ e $B B^{\prime}$ respectivamente. $\operatorname{Logo} A^{\prime \prime}=\left(\frac{l}{2}, \frac{1}{2}\right)$; e $B^{\prime \prime}=\left(\frac{a}{2}, \frac{l}{2}\right)$. Pela geometria da figura os três ângulos que são representados por $\beta$ são iguais. Assim: A partir do vértice A: (I) $\tan \beta=\frac{1}{l}$. Considerando o vértice em $\mathrm{B}$ : (II) $\tan \beta=\frac{\frac{l}{3}}{a}$. Considerando o vértice em $B^{\prime \prime}$ : (III) $\tan \beta=\frac{l-a / 2}{l-1 / 2}=\frac{l-a}{l-1}$. Igualando (I) $=$ (II) $\frac{1}{l}=\frac{\frac{l}{3}}{a} \Rightarrow a=\frac{l^{2}}{3}$. Igualando $(\mathrm{II})=(\mathrm{III}) \quad \frac{\frac{l}{3}}{a}=\frac{l-a}{l-1} \Rightarrow l^{3}-3 l^{2}+3 l-3=0 \Rightarrow(l-1)^{3}-2=0$ E substituindo $t=l-1$ temos: $(t)^{3}-2=0 \Rightarrow \mathrm{t}=\sqrt[3]{2}$ que prova a solução do problema deliano.

Com dobraduras de papel é possível resolver qualquer equação cúbica, o que é impossível de ser feito com régua e compasso.

\section{RESULTADOS}

Para verificar a influência do origami em sala de aula, foi desenvolvido um projeto que consistia em confeccionar dobraduras simples para que os alunos conhecessem os principais elementos geométricos. Esta atividade foi realizada em duas turmas do 7ํo ano de uma escola pública de Presidente Prudente com 
duração de 8 aulas em cada uma. 0 projeto foi apresentado à professora e alunos, que aceitaram participar voluntariamente da pesquisa e acordaram que desenvolveriam as atividades com compromisso e atenção. Inicialmente foi aplicado um questionário com o propósito de obter uma avaliação diagnóstica para a verificação dos conhecimentos prévios dos discentes acerca dos elementos geométricos. Os discentes deveriam escrever uma definição e/ou representar o que entendiam por: ângulo; ângulo reto; bissetriz; retas paralelas; retas perpendiculares; retas concorrentes; segmento de reta; triângulo; triângulo equilátero; quadrado e vértice. Cerca de $70 \%$ dos alunos deixou a maior parte dos itens em branco. A professora relatou que a sala apresenta grandes dificuldades de aprendizado devido à defasagem em conteúdos de anos anteriores. A análise diagnóstica foi tabulada, os itens em branco foram considerados como erros. A maior parte dos alunos enfrentou dificuldade tanto em representar como em descrever os elementos geométricos. No item que se refere ao quadrado, grande parte representou por um quadrilátero com ângulos retos, mas sem congruência dos lados. A maior assertiva foi quanto à representação do triângulo. Os resultados das duas salas foram semelhantes, com pequena variação entre elas. A média de acertos em ambas as salas ficou abaixo de $20 \%$.

As aulas envolvidas no projeto foram ministradas durante quatro semanas seguidas, acontecendo em aulas duplas em cada uma das salas. 0 material utilizado foi baseado em Carneiro e Spira (2005). As atividades desenvolvidas através do recurso do origami foram: determinação de retas perpendiculares a um ponto dado; construção de duas retas paralelas; construção da reta mediatriz a um segmento dado; determinação da reta bissetriz de um ângulo qualquer; determinação da altura e ortocentro de um triângulo; construção de triângulo equilátero; construção do quadrado; verificação da razão áurea; construção de pentágono regular; trissecção de um ângulo agudo. Na última aula, após a realização das atividades, os alunos responderam novamente ao questionário conceitual. Observou-se que todos os elementos pesquisados obtiveram melhora após o trabalho com o origami. A média de acertos subiu consideravelmente nas duas salas. Além disso, a maior parte dos alunos não deixou questões em branco e conseguiu além de definir, representar grande parte dos conceitos. Segue abaixo os gráficos que comparam os resultados entre a avaliação diagnóstica e a avaliação final.

Gráfico 1: Comparação de resultados 7ํB

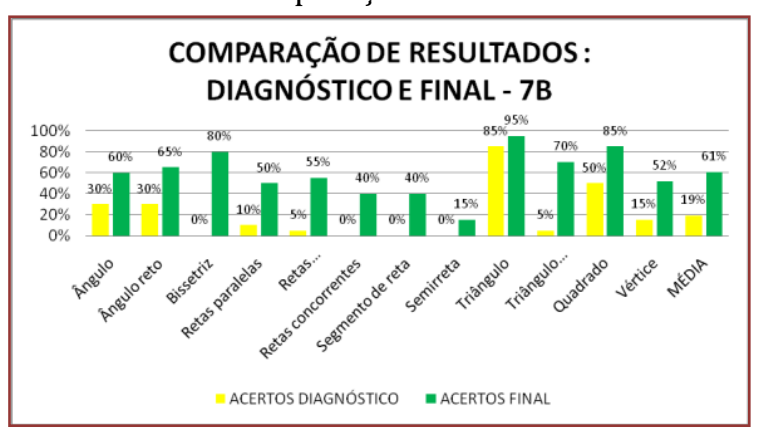

Fonte: Autoria própria.

Gráfico 2: Comparação de resultados 7ํㅡ

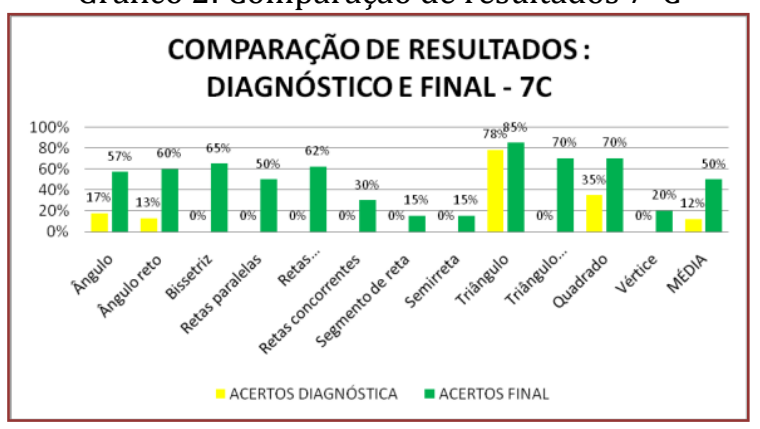

Fonte: Autoria própria. 
Além da reaplicação do questionário após a realização das atividades foi solicitado aos alunos que respondessem sobre seu grau de satisfação em relação às aulas. A maior parte dos discentes afirmou que a atividade foi interessante, diferente e divertida. Muitos deles disseram que a realização das atividades não foi fácil, pois não têm contato com o uso de dobraduras usualmente, entretanto a maioria acrescentou que a confecção do origami parece uma brincadeira e que gostaram do desafio. 0 desenvolvimento do projeto foi agradável sendo perceptível a empatia dos aprendizes em relação ao material utilizado. Os resultados espelham o que foi descrito por Manso $(2008$, p.3)

Os resultados deste estudo apontam para que ao trabalhar com as dobragens, a grande maioria dos alunos da turma: (1) conseguiram desenvolver uma aprendizagem consistente, através da organização das ideias; (2) demonstraram entusiasmo por novos desafios e por novas descobertas; (3) desenvolveram a sua capacidade de autocrítica; (4) reconheceram o valor do trabalho em grupo e a importância do papel do professor.

Uma pequena parcela descreveu que gostou bastante das atividades no início do projeto, mas acharam que elas se tornaram um tanto repetitivas no decorrer das aulas. 0 cansaço demonstrado pelos alunos devido a necessidade da repetição de procedimentos também foi relatado por Manso (2008). Assim, com esta pesquisa, constatou-se melhoras tanto no aspecto intelectual quanto no atitudinal. Houve elevação de cerca de $40 \%$ na média de acertos das avaliações. Ainda foi notória a motivação para o desenvolvimento dos procedimentos bem como a cooperação entre os pares.

\section{CONSIDERAÇÕES FINAIS}

A geometria do Origami desenvolvida a partir da década de 70 fundamenta a técnica que pode ser muito eficaz na resolução de diversos problemas matemáticos. 0 axioma 6 é o diferencial que permite solucionar questões que outrora não eram possíveis com os instrumentos euclidianos. Este item torna possível a resolução de equações cúbicas como a trissecção do ângulo e o problema deliano.

A inserção deste instrumento no ensino tem sido alvo de estudo nos últimos anos, inclusive por alunos mestrandos do PROFMAT, entretanto ainda não repercutiu em sala de aula de maneira desejável. Até mesmo o currículo oficial do estado de São Paulo (2010) embora tenha sido reestruturado a partir do ano de 2008, não aborda o uso do origami como instrumento de ensino. 0 uso de dobraduras pode ser muito útil no ensino da matemática. A utilização de materiais concretos em sala torna a aula dinâmica e a aprendizagem mais significativa. 0 trabalho desenvolvido em campo alcançou a receptividade dos alunos. Percebe-se, contudo, que a utilização sequenciada do mesmo instrumento também o torna cansativo. Alguns alunos relataram em suas avaliações que as atividades finais tornaram-se repetitivas.

Conclui-se que é imprescindível no cotidiano da sala de aula diversificar metodologias e estratégias, por isso propusemos o origami como mais um instrumento que auxilie o docente nesta importante e desafiadora missão que é o ensino da matemática.

\section{AGRADECIMENTOS}

Agradeço à fundação Capes pelo apoio financeiro no desenvolvimento deste projeto.

\section{REFERÊNCIAS}

[1] Cavacami, Eduardo. Furuya ,Yolanda Kioko Saito. Explorando Geometria com Origami. Departamento de Matemática da Universiade Federal de São Carlos. www.dm.ufscar.br/ yolanda/origami/origami.pdf, 2009

[2] Eves, Howard. Introdução à história da matemática. Campinas: Editora Unicamp, 2004, p.843.

[3] Freitas, Bruno Amaro. Os problemas clássicos da geometria: uma abordagem com o uso do Origami. 2013. 47f. Dissertação (Mestrado). -Universidade Federal do Rio de Janeiro. Rio de Janeiro - 2013

[4] Lang, Robert J. Origami and Geometric Constructions, 2010. Disponível em:

[5] < http://www.langorigami.com/science/hha/origami_constructions.pdf>. Acesso em 06 mar. 2015.

[6] Lucero, Jorge C. A trisecção de um ângulo, Departamento de Matemática da Universidade de Brasília, $2006^{\mathrm{a}}$. Disponível em: <www.mat.unb.br/lucero/origami/Notas_3.pdf>. Acesso em 10 out. 2015 
[7] _ _ o problema Deliano, Departamento de Matemática da Universidade de Brasília, 2006b. Disponível em: <www.mat.unb.br/ lucero/origami/Notas_2.pdf>. Acesso em 10 out. 2015.

[8] Manso, Roberta L. D. Origami: uma abordagem pedagógica para o ensino de geometria no 9ano. $2008244 \mathrm{f}$. Dissertação (Mestrado).- Universidade de Lisboa, Lisboa.

[9] Monteiro, Liliana Cristina Nogueira. Origami: História de uma Geometria Axiomática. 2008.111f. Dissertação (Mestrado).- Universidade de Lisboa, Lisboa, 2008.

[10] Oliveira, Fátima Ferreira. Origami: Matemática e Sentimento, 2004. Disponível em: http://www.nilsonjosemachado.net/20041008.pdf. Acesso em 01 set. 2015.

[11] São Paulo (Estado) Secretaria da Educação. Currículo do Estado de São Paulo: Matemática e suas Tecnologias. São Paulo: SEE, 2010. 


\section{Capítulo 11}

Ensino de geometria como temática de uma formação continuada

\section{Waléria de Jesus Barbosa Soares \\ Carlos André Bogéa Pereira}

Resumo: Durante o ano de 2018, foi oferecida pela Rede Municipal de Educação de São Luís, Estado do Maranhão, a Formação Continuada em Matemática para professores dos anos iniciais - FORMAT. A formação teve a Geometria como uma das oito temáticas a serem trabalhadas ao longo do processo, pensadas e escolhidas pelos próprios professores envolvidos. Neste sentido, o objetivo deste texto é apresentar como se deu o desenvolvimento dessa temática durante a formação que buscou responder ao seguinte questionamento dos professores: o que nós, professores que ensinam matemática, devemos saber sobre o que é e como ensinar a geometria aos estudantes dos anos iniciais do Ensino Fundamental? Por meio de observação e análise das narrativas dos professores, constatamos que o envolvimento dos mesmos em uma formação pensada para e por eles, partindo de suas necessidades, contribuiu para que vissem a relevância da aprendizagem matemática significativa. E ainda, como resultados, os professores, além de refletirem sobre o que é a Geometria, discutiram sobre novas metodologias e recursos para o seu ensino, e elaboraram atividades que priorizavam as seguintes dimensões para o ensino de geometria: história da matemática; os jogos explorando o lúdico; o material concreto; e, a resolução de situações-problema. Os resultados desta formação foram apresentados em um seminário que envolveu todos os professores participantes da mesma, no final do ano letivo.

Palavras-chave: Formação continuada. Geometria. Ensino. 


\section{INTRODUÇÃO}

Durante a formação inicial de professores que ensinam matemática, ou seja, os pedagogos, nem sempre a Matemática é apresentada a partir de suas unidades temáticas e suas dimensões, onde o professor tem contato com a teoria e a prática que futuramente deverá ser desenvolvida nas salas de aula em que atuarão.

Ao deixar de ter esse contato, os professores tendem a repassar a matemática aos estudantes, da mesma forma como aprenderam: sem base teórica e com poucas metodologias que levam o estudante a perceber a matemática como significativa.

Buscando soluções para essa problemática, a Rede Municipal de Educação de São Luís, ofereceu no ano de 2018, a Formação Continuada em Matemática para professores dos anos iniciais - FORMAT. A formação aconteceu durante o segundo semestre, em oito encontros quinzenais e levou em consideração as indagações dos professores sobre "como ensinar aquilo que não sabemos?".

Cada um dos encontros tratou de uma temática escolhida pelos próprios professores, a partir de suas necessidades. A saber, foram:

\begin{tabular}{|c|c|}
\hline Encontro & Temática \\
\hline 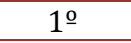 & Geometria Espacial e Geometria Plana \\
\hline $2^{\circ}$ & Sistema de Numeração Decimal \\
\hline 3 o & Pensamento Algébrico \\
\hline 40 & As operações: Adição, Subtração e Multiplicação \\
\hline 50 & A operação: Divisão \\
\hline $6^{0}$ & Frações \\
\hline 7음 & Grandezas e Medidas \\
\hline $8^{0}$ & Educação Estatística \\
\hline
\end{tabular}

A escolha dos professores pela geometria como uma das temáticas vai ao encontro do que ressaltam Nacarato, Gomes e Grando (2008, p. 27) quando dizem que "esse campo matemático raramente é trabalhado nas escolas públicas e, quando o é, ocorre no final do ano ou de forma totalmente destituída de sentido e significado para o aluno".

Neste sentido, o objetivo deste texto é apresentar como se deu o desenvolvimento da temática geometria, buscando responder ao seguinte questionamento dos professores: o que é geometria e de que forma podemos trabalhá-la nos anos iniciais do Ensino Fundamental?

As considerações aqui apresentadas partem da experiência de dois formadores (autores deste texto), a partir da observação e análise das narrativas dos professores, durante a formação.

\section{2 É PRECISO COMPREENDER O QUE É A GEOMETRIA}

Muitos professores não conseguem definir o que é a geometria. Alguns conseguem somente identificar os elementos ou objetos que ela investiga. 0 ponto inicial do encontro formativo foi o questionamento: como ensinar geometria se não sabemos o que ela é?

Foi preciso definir a geometria. Tomamos Ferreira (1999) e a concebemos como:

[...] ciência que investiga as formas e as dimensões dos seres matemáticos (...) um ramo da matemática que estuda as formas, plana e espacial, com as suas propriedades, ou ainda, ramo da matemática que estuda a extensão e as propriedades das figuras (geometria Plana) e dos sólidos (geometria no espaço). (FERREIRA, 1999, p.983)

Chegamos à conclusão de que ela é a parte da matemática que tem por objetivo analisar, organizar e sistematizar os conhecimentos espaciais.

Mas, e na escola, como a definimos? Para isso, primeiramente tomamos a Matemática como o "alicerce de quase todas as áreas de uma arquitetura que permite desenvolver os níveis cognitivo e criativo" (BIEMBENGUT; HEIN, 2000, p.9), para então compreender a geometria como uma unidade temática 
dentro do componente curricular matemática, que está no tripé básico dos conhecimentos matemáticos, que conta ainda com medidas e números como temáticas (LORENZATO, 2006).

A geometria é assim um dos ramos da matemática de suma importância para aquisição de conhecimentos matemáticos, pois "desencadeia no homem o pensamento voltado à realidade concreta (observar, descrever, comparar, tocar, construir)" (SCHMITZ; LEDUR, MILANI, 1994, p.78).

Buscamos na história da geometria, suas raízes. Concordamos com Pavanello (2004, p. 131), quando diz que "os professores em sua formação inicial ou continuada precisam ter algum contato como o modo pelo qual os matemáticos produzem a matemática, os procedimentos que utilizam nessa produção".

Entendemos então, que a geometria se desenvolveu ao longo do tempo, a partir da necessidade de o homem utilizar conhecimentos sobre a medida da terra, logo comungamos com Boyer (1996, p. 5), quando diz que "o desenvolvimento da geometria pode ter sido estimulado por necessidades práticas de construção e demarcação de terras, ou por sentimentos estéticos em relação a configurações e ordem".

Para ampliar o entendimento de como a geometria foi desenvolvida ao logo dos tempos, buscamos nas histórias de vida e histórias de vida profissional de geômetras, como se deu esse desenvolvimento e quais as suas contribuições para o ensino da matemática.

Entendemos que a história da matemática é importante e relevante para o ensino de geometria, pois "mostra como surgiu, para que serve e onde serve. Portanto, acredita-se que podemos ensinar matemática pura e aplicada nas escolas de forma que o aluno se sinta íntimo da disciplina como parte de sua vida" (ROSA NETO, 2003, p. 7-8).

Os matemáticos (geômetras) investigados na formação e que estavam associados a conhecimentos relativos à matemática dos anos iniciais, foram:

$\begin{array}{ll}- & \text { Pitágoras; } \\ - & \text { Euclides; } \\ - & \text { Renés Descartes; e, } \\ \text { - } & \text { Gauss. }\end{array}$

Vimos também, como a geometria foi/é utilizada por vários povos ou comunidades. Nesse ponto, demos destaque aos estudos sobre cestarias, pinturas e jogos desenvolvidos nas culturas indígenas e africanas.

A relevância de um trabalho que envolve a etnomatemática foi assim discutida, através do entendimento de Sebastiani (2002):

Através do conceito de etnomatemática chama-se a atenção para o fato de que a matemática, com as suas técnicas e verdades, constitui um produto cultural, salienta-se, que cada povo, cada cultura e cada sub-cultura desenvolve a sua própria matemática, em certa medida, específica. (SEBASTIANI, 2002, p.13)

Dentro da regionalidade maranhense, buscamos reconhecer a geometria nas pinturas dos corpos indígenas de tribos como os Guajajaras e os Krikatis, que habitam em cidades do interior maranhense. Acreditamos que levar essa geometria para sala de aula faz com que os estudantes percebam que "a geometria está por toda parte..., mas é preciso conseguir enxergá-la..." (LORENZATO, 1995, p. 5).

Reconhecemos também a geometria nas peças produzidas pelas rendeiras da cidade de Paço do Lumiar, situada na região da Ilha de são Luís, capital do Estado, o que nos fez perceber que, "a matemática faz parte da vida social de cada um de nós, é impossível separá-la da realidade. Dessa forma, devemos repensar sobre como ensinar essa disciplina, buscando novos caminhos e olhares ao ensiná-la" (BEZERRA; MOURA, 2014, p. 735).

Desta forma, tivemos oportunidade de reconhecer que a geometria está na vida das pessoas, nos padrões da natureza, nos objetos que utilizamos, nas culturas, indo além daquela apresentada no ambiente escolar.

\section{A GEOMETRIA NAS AULAS DE MATEMÁTICA}

A dificuldade que os estudantes enfrentam com relação ao conhecimento geométrico é reflexo, muitas vezes, do ensino que foi ministrado. E esse método de ensino é fruto de como os professores, anteriormente, aprenderam. 
Tomando Guimarães, Vasconcellos e Teixeira (2006), acreditamos que os empecilhos encontrados nas aulas de matemática sobre geometria, referem-se a três fatores principais: o não reconhecimento da utilidade da geometria por parte dos professores, as dificuldades para desenvolver o raciocínio hipotéticodedutivo e as falhas advindas da formação dos professores. Sobre estes, discutimos, no encontro formativo, o terceiro.

Encontramos muitos professores que se lamentam de como a geometria lhes foi apresentada em sua formação inicial, desprovida de significado, e muitas vezes isolada das outras unidades matemáticas. Assim, "acabam repassando aquilo que aprenderam, limitando-se a exigir do estudante apenas nomes de figuras, sem se preocuparem com o reconhecimento das propriedades das mesmas" (PAVANELLO, 2001, p.183).

Isso acarreta em uma formação deficiente para os estudantes, pois entendemos que:

Os conceitos geométricos constituem parte importante do currículo de Matemática no ensino fundamental, porque, por meio deles, o aluno desenvolve um tipo especial de pensamento que lhe permite compreender, descrever e representar, de forma organizada, o mundo em que vive. 0 trabalho com noções geométricas contribui para a aprendizagem de números e medidas, pois estimula a criança a observar, perceber semelhanças e diferenças, identificar regularidades e vice-versa. (BRASIL, 1997, p. 56)

É preciso conceber que a geometria ajuda o estudante a entender o mundo. Se ela não lhe é apresentada desta forma, como poderá desenvolver capacidades como olhar, comparar, medir, adivinhar, generalizar e abstrair? (BULOS, 2011, p. 5).

Sobre a importância do olhar, pensamos tal qual Kaleff (2003) quando cita os estudos de Van Hiele em que "a visualização, a análise e a organização informal (síntese) das propriedades geométricas relativas a um conceito geométrico são passos preparatórios para o entendimento da formalização do conceito" (p.14).

Então, para esse fim, não só o professor deve mudar suas concepções de ensino da geometria, mas todo o sistema. É necessário se pensar em um currículo integrador, em que se perceba que a geometria é o elo entre a aritmética e a álgebra (LORENZAT0, 1995, p.6).

Se este elo não acontece, as unidades temáticas são vistas como ramos da matemática isolados e a aprendizagem fica fragmentada, fazendo-nos concordar com Lindquist e Shulte (1994, p.240) quando dizem que "são cada vez maiores os indícios de que as dificuldades de nossos alunos em cálculo se devem a uma formação deficiente em geometria".

Após reconhecermos a importância da geometria no ensino de matemática, partimos para a reflexão sobre o desenvolvimento do raciocínio que a ela está atrelada.

Entendemos que a geometria está em nosso dia a dia, e buscamos refletir sobre o que significam seus conceitos. E, assim, concordamos com Dienes (1974, p.01), quando diz que "os conceitos não se ensinam tudo que se pode fazer é criar, apresentar situações e as ocorrências que ajudarão a formá-los".

Corroboramos com a ideia de que, nos anos iniciais do Ensino Fundamental, deve-se partir da geometria espacial para a planificação das figuras, momento em que o estudante percebe o abstrato a partir do concreto. Isso nos levou a compreender, segundo Fainguelernt (1995), que a geometria desempenha um papel fundamental na educação porque ativa as estruturas mentais na passagem de dados concretos e experimentais para os processos de abstração e generalização.

\section{ELABORAÇÃO DE ATIVIDADES QUE ENVOLVEM A GEOMETRIA}

A escolha inadequada de atividades a serem realizadas nas salas de aula pode comprometer a visão que se construirá sobre a geometria, acarretando em estudantes que sequer conseguem identificar elementos ou figuras geométricas.

0 que se deve buscar, através do ensino de geometria, é uma matemática mais humanizada, menos abstrata ou desligada da realidade. Esta visão pode mudar quando proporcionamos atividades que despertem o potencial investigativo dos estudantes dentro das aulas de matemática.

Propomos assim, um ensino geometria de caráter mais experimental (NACARATO; PASSOS, 2003). Discutiu-se com os professores sobre como o estudante deve ver o ensino de geometria e concordamos 
que devemos propor metodologias que lhes permitem, "ao ensinar-lhe [o estudante] certo conteúdo, desafiá-lo a que se vá percebendo na e pela própria prática, sujeito capaz de saber" (FREIRE, 1996, p. 124).

Associar essas atividades à realidade dos estudantes faz com que eles percebam que a geometria está em seus contextos sociais. Portanto, é preciso oportunizar. Vale ressaltar que, todas as formas de trabalhar com a geometria nas aulas de matemática devem levar em consideração o ano escolar do estudante, adequando as atividades à sua idade.

0 papel do professor como mediador e pesquisador de novas metodologias é ponto fundamental nesse processo. É ele quem planejará as atividades e pensará nas metodologias que envolvem o ensino de geometria.

Nesse contexto, concordamos com Pimenta (1999) quando ressalta que o profissional de educação é e sempre será a peça fundamental na aprendizagem de forma específica, e no desenvolvimento da sociedade de forma geral.

Durante o encontro formativo, pensamos em quais materiais poderiam ser utilizados durante as aulas de matemática para alcançar nosso objetivo. Sobre eles destacamos alguns.

0 uso de livros de literatura infanto-juvenil que trate da geometria é viável, pois possibilita ao aluno uma viagem prazerosa ao mundo da matemática, que pode ser por ele desconhecido. Sobre este tipo de literatura, concorda-se com Resende (1993),

A cada mergulho nas camadas simbólicas dos livros, emerge-se vendo o universo interior e exterior com mais claridade. Entra-se no território da palavra com tudo o que se é e se leu até então, e a volta se faz com novas dimensões, que levam a re-inaugurar o que já se sabia antes. (RESENDE, 1993, p. 164)

Reforçamos que, as histórias sobre a geometria são um contributo, pois mostram aos estudantes que a matemática foi construída ao longo do tempo por pessoas normais, e não por gênios. Sendo assim, são pessoas que também podem ter cometido erros. Aliás, essa parte da história nunca aparece nos livros didáticos, segundo Lopes (2005, p.36), "os obstáculos de percurso e as visões errôneas no decorrer da construção do conhecimento, dificilmente estão descritos nos livros didáticos, principalmente naqueles voltados à área das ciências exatas".

Tão importante quanto a literatura são os materiais concretos e/ou manipulativos. Vimos nos mesmos, bons recursos didáticos que contribuem para a formação das imagens mentais dos estudantes (NACARATO, 2005). Para isso é necessário entender que:

Nas atividades de ensino da geometria, envolvendo o uso de materiais, é preciso estar duplamente vigilante para que toda informação proveniente de uma manipulação esteja em sintonia com algum pressuposto racional e, ao mesmo tempo, que todo argumento dedutivo esteja associado a alguma dimensão experimental. Acreditamos que este é o primeiro passo para valorizar uma interpretação dialética para o uso dos materiais didáticos. Evitar uma racionalidade vazia desprovida de significado, assim como evitar toda espécie de atividade empírica desconexa de um objetivo educacional previamente analisado. (PAIS, 2000, p. 13-14)

Procuramos elaborar atividades com o uso de materiais concretos como o Geoplano e o Tangram, e outros materiais manipulativos construídos através de sucata, por exemplo. A utilização desses materiais "fornecem oportunidades para raciocinar com objetos e, portanto, para ensinar a resolver problemas" (LINDQUIST; SHULTE, 1994, p. 77).

Na perspectiva de que, segundo Atalay (2007), a natureza inspira tanto o artista quanto o cientista, utilizamos também obras de arte para elaborar atividades a partir das mesmas. Concluímos que "o ensino da Matemática só poderá contribuir de forma positiva e significativa aos alunos, se o olhar fragmentado e limitado dos professores for desconstruído, percebendo as múltiplas possibilidades que favorecem essa interdisciplinaridade" (SOARES, 2013, p. 36).

Refletimos também sobre o uso das tecnologias no ensino de geometria e com ela, a contribuição de softwares. Por meio deles, os estudantes aprendem a aplicar, construir, explorar e manipular conceitos geométricos. Como exemplo, discutimos sobre o Geogebra, que associa geometria e álgebra, e do que podemos fazer com ele durante as aulas de geometria. 
Concordando com Contiero e Gravina (2001), entendemos que,

Com os recursos tecnológicos disponíveis, diferente poderia ser o processo de aprendizagem da matemática a se instalar nas escolas - tanto na provocação das habilidades cognitivas dos alunos, quanto na integração de conteúdos que normalmente são estudados separadamente e desta forma o contexto da aprendizagem também poderia se aproximar daquele de natureza interdisciplinar (CONTIERO; GRAVINA, 2001, p. 3)

Os estudantes de hoje são seduzidos pela tecnologia, pois "percebem o fluxo constante de informações com as quais convive e, por consequência, como este novo mundo tecnológico está transformando a maneira pela qual aprendem" (RANCAN, 2011, p. 17).

A partir de todas essas reflexões, e pensando no que ressaltam Ponte e Serrazina (2000) sobre a falta de atenção dos estudantes durante as aulas de matemática e, consequentemente, as aulas de geometria, outras atividades foram pensadas e elaboradas, durante as formações, para que potencializassem o ensino de geometria nos anos iniciais do ensino fundamental.

Essas atividades envolveram:

Ditado matemático;

Bingo e dominó geométricos;

Caça palavras geométrico;

Cruzadinhas;

Blocos lógicos;

Leitura de imagem de obras de arte; entre outras.

É interessante perceber que todas essas atividades deveriam associar teoria e prática, conceitos geométricos e procedimentos, pois os materiais nelas utilizados,

[...] contribuem para a compreensão dos conceitos geométricos, porém, não podem ser considerados como determinantes, pois "sua finalidade é servir de interface mediadora para facilitar a relação entre o professor, o aluno e o conhecimento em um momento preciso da elaboração do saber". (PAIS, 2000, p. 2-3)

Ressaltamos que, quando os conteúdos de geometria trabalhados nas aulas de matemática partem de situações vivenciadas pelos estudantes, facilitam o entendimento de que, a "geometria envolve o estudo de um amplo conjunto de conceitos e procedimentos necessários para resolver problemas do mundo físico e de diferentes áreas do conhecimento" (BRASIL, 2017, p. 269).

É primordial que permitamos que o estudante experimente a geometria, pois assim desenvolverá um olhar geométrico sobre a realidade a sua volta.

\section{ALGUMAS CONSIDERAÇÕES SOBRE OS RESULTADOS DA FORMAÇÃO}

Acreditamos que as temáticas das formações continuadas que envolvem professores que ensinam matemática, devem surgir a partir das necessidades dos próprios professores envolvidos (GATTI, 2009).

Desta forma, o trabalho aqui apresentado se caracterizou como colaborativo (NACARAT0, 2006), a partir do momento em que a temática foi discutida com os professores e escolhida pelos professores.

A Geometria, como pretendida no objetivo da formação, foi refletida a partir das indagações dos professores dos anos iniciais do Ensino Fundamental sobre o que ensinar e como ensinar, de forma que os mesmos aprenderam novos conhecimentos, discutiram novas metodologias e recursos para aplicarem em sala de aula.

Sobre o trabalho dos professores em sala de aula, o retorno era sempre trazido para o encontro formativo seguinte. Logo, de acordo com os professores, a partir de suas narrativas durante as formações, o ensino se tornou mais motivador e a aprendizagem mais significativa para os estudantes, a partir das atividades elaboradas. 
Constatamos enfim, que educar estudantes matematicamente, para além dos muros da escola, necessita de um professor em constante formação.

Logo, ao alcançarmos o objetivo de trabalhar com os professores que ensinam matemática sob um viés da reflexão sobre a prática a partir de uma unidade temática da matemática - a Geometria -, possibilitou-nos perceber que se aprende fazendo e refletindo sobre a própria prática.

\section{REFERÊNCIAS}

[1] Atalay, B. A Matemática e a Mona Lisa, a confluência da arte com a ciência. São Paulo: Mercuryo, 2007.

[2] Bezerra, S. M. C. B.; Moura, A. R. L. de. Contribuições da terapia filosófica wittgensteiniana no modo de ver os usos e significados de matemática em práticas de formação docente. In: Simpósio Linguagens e Identidades da/na Amazônia Sul-Ocidental: artes, silêncios e silenciamentos; Colóquio Internacional "As Amazônias, as Áfricas e as Áfricas na Pan-Amazônia”, 7., 2014, Rio Branco. Anais ... Rio Branco: UFAC, 2014. pp. 724-736.

[3] Biembengut, M. S.; Hein, N. Modelagem matemática no ensino. São Paulo: Contexto, 2000.

[4] Boyer, C. B. História da Matemática. 2. ed. São Paulo: Edgard Blücher, 1996. Tradução: Elza F. Gomide.

[5] Brasil. Secretaria de Educação Básica. Base Nacional Comum Curricular. Brasília: MEC/SEF, 2017, 468 p.

[6] _. Secretaria de Educação Fundamental. Parâmetros Curriculares Nacionais: Matemática. Brasília: MEC/SEF, 1997, 142 p.

Bulos, A. M. M. O ensino da geometria nos anos iniciais do ensino fundamental. In: XIII CIAEM - IACME, Recife, Brasil, 2011.

[7] Contiero, L. O.; Gravina, M. A. Modelagem com o GeoGebra: uma possibilidade para a educação interdisciplinar? Revista Novas Tecnologias na Educação, v. 9, n. 1, julho, 2011.

[8] Dienes, Z. P. Exploração do espaço e prática da medição. São Paulo: Editora pedagógica e Universitária, 1974.

[9] Fainguelernt, E. K. O Ensino de Geometria no 1 o e $2^{\circ}$ Graus. In: Educação Matemática em Revista - SBEM 4, 1995, pp. 45- 52.

[10] Ferreira, A. B. H. Novo dicionário Aurélio da Língua Portuguesa. 2. ed. Curitiba: Nova Fronteira, 1999.

[11] Freire, P. Pedagogia da Autonomia: saberes necessários à prática educativa. São Paulo: Paz e Terra, 1996 (Coleção Leitura).

[12] Gatti, B. A. Formação de professores: condições e problemas atuais. Revista Brasileira de Formação de Professores, Cristalina, maio, v. 1, n. 1, 2009. pp. 90-102.

[13] Guimarães, S. D.; Vasconcellos, M.; Teixeira, L. R. M. O ensino de geometria nas séries iniciais do Ensino Fundamental: concepções dos acadêmicos do Normal Superior. Zetetiké. Unicamp, jan/jun, v. 14, n. 25, 2006. pp. 93 106.

[14] Kaleff, A. M. M. R. Vendo e entendendo poliedros: do desenho ao cálculo do volume através de quebracabeças e outros materiais concretos. Niterói: EdUFF,2003.

[15] Lindquist, M. M.; Shulte, A. P. (Orgs.). Aprendendo e ensinando geometria. São Paulo: Atual, 1994.

[16] Lopes, J. O livro didático, o autor e as tendências em Educação Matemática. En Nacarato, A. M.; Lopes, C. E. Escritas e leituras na Educação Matemática. pp. 35-62. Belo Horizonte: Autêntica, 2005.

[17] Lorenzato, S. Educação Infantil e percepção matemática. Campinas: Autores Associados, 2006.

[18] _._. Por que não ensinar geometria? Educação Matemática em Revista, Rio de Janeiro, v. 1, n. 4, pp.3-13, jan. 1995. Semestral.

[19] Nacarato, A. M. Eu Trabalho Primeiro no Concreto. Revista de Educação Matemática, São Paulo, v. 9, n. 9-10, pp. 1-6, 2005. SBEM-SP. Disponível em: <http://www.sbempaulista.org.br/revedmatvol9.pdf>. Acesso em: 25 jan. 2019.

[20] Nacarato, A. M. et al. Professores e futuros professores compartilhando aprendizagens: dimensões colaborativas em processo de formação. In: NACARATO, A. M.; PAIVA, M. A. V. (Orgs.). A formação do professor que ensina matemática: perspectivas e pesquisas. Belo Horizonte: Autêntica, 2006. pp. 197-212.

[21] Nacarato, A. M.; Gomes, A. A.; Grando, R. C. Grupo colaborativo em Geometria: uma trajetória... uma produção coletiva. In: Nacarato, A. M.; Gomes, A. A.; Grando, R. C. (Orgs.). Experiências com Geometria na escola básica: narrativas de profesores em (trans)formação. São Carlos: Pedro \& João Editores, 2008.

[22] Nacarato, A. M.; Passos, C. L. B. A Geometria nas Séries Iniciais: Uma análise sob a perspectiva da prática pedagógica e da formação de professores. São Carlos: EdUFSCar, 2003. 
[23] Pais, L. C. Uma análise do significado da utilização de recursos didáticos no ensino da Geometria. Anped. 23ạ Reunião, Caxambu, 2000. Disponível em: <http://anped.org.br/23/textos/1919t.pdf>. Acesso em: 21 jan. 2019.

[24] Pavanello, R. M. A Geometria nas séries iniciais do ensino fundamental: Contribuições da pesquisa para o trabalho escolar. In: PAVANELLO, R. M. Matemática nas series iniciais do ensino fundamental: a pesquisa e a sala de aula, 2(6). São Paulo. Coleção SBEM, 2004. pp. 129-143.

[25] _ - Geometria: atuação de professores e aprendizagem nas séries iniciais. In: Simpósio Brasileiro de Psicologia da Educação Matemática, 1., 2001, Curitiba. Anais... Curitiba: [s. n.], 2001. pp. 172-183.

[26] Pimenta, S. G. Formação de professores: identidade e saberes da docência. In: Pimenta, S. G. (Org.). Saberes pedagógicos e atividade docente. São Paulo: Cortez Editora, 1999. p. 15-34.

[27] PONTE, J.; Serrazina, L. X. A didática da matemática do 1ociclo. Lisboa: UA, 2004.

[28] Rancan, G. Origami e Tecnologia: Investigando Possibilidades Para Ensinar Geometria No Ensino Fundamental. Porto Alegre, RS, 2011, 80f. Dissertação (Mestrado em Ciências e Matemática) - Faculdade de Física PUCRS, Porto Alegre, RS.

[29] Resende, V. M. Literatura Infantil e Juvenil. Vivências de leitura e expressão criadora. RJ: Saraiva, 1993.

[30] Rosa Neto, E. Didática da Matemática. São Paulo: Ática, 2003.

[31] Sebastiani, E. F. Cidadania e Educação Matemática. Educação Matemática em Revista- Revista da Sociedade Brasileira de Educação Matemática. São Paulo, ano 9, n.1, pp. 13-18, jul. 2002.

[32] Schmitz, C. C.; Ledur, E. A.; Milani, M. D. N. Geometria de 1a a 4⿳a série: uma brincadeira séria. São Leopoldo, RS: Unisinos, 1994.

[33] Soares, W. J. S. A matemática nas artes contemporâneas: possibilidade para uma atividade interdisciplinar. Educação Matemática em Revista. São Paulo, ano 18, n. 40, pp. 30-37, nov. 2013. 


\section{Capítulo 12}

Resultados Finais de uma atividade diagnóstica sobre conhecimentos geométricos de alunos do $6^{\circ}$ ano do ensino fundamental

\section{Geovana Raquel Pereira da Silva}

\section{Luana Cardoso da Silva}

\section{Cristiane Fernandes de Souza}

Resumo: Apresentamos nesse texto algumas considerações acerca do processo e dos resultados da aplicação de uma Atividade Diagnóstica final realizada com três turmas do 6ำ ano do Ensino Fundamental (totalizando 94 alunos), dos turnos matutino e vespertino, de uma escola pública do município de Mamanguape/PB. Essa atividade diagnóstica versava sobre conteúdos de Geometria, tais como: reconhecimento de figuras planas e não planas, classificação de sólidos em poliedros e corpos redondos, planificação de sólidos geométricos, localização espacial. A pesquisa foi realizada com o objetivo de investigar os conhecimentos e habilidades geométricas adquiridas por esses alunos ao final de uma intervenção didática realizada nas três turmas, de um projeto de ensino desenvolvido dentro do Programa de Licenciatura - PROLICEN/UFPB, desenvolvido no ano de 2015. Com os resultados obtidos na análise das respostas da Atividade foi possível perceber uma melhora significativa com relação à primeira Atividade Diagnóstica, realizada antes da intervenção didática.

Palavras-chave: Ensino-Aprendizagem da Geometria. Ensino Fundamental. Habilidades Geométricas. 


\section{INTRODUÇÃO}

A Geometria é considerada por muitos pesquisadores como a área da Matemática que favorece ao aluno a desenvolver diferentes capacidades, tais como, deduzir, intuir, abstrair, formalizar, entre outras. Entretanto, o que se tem observado a partir dos resultados de avaliações em larga escala (no âmbito federal, estadual e municipal) é que os alunos avaliados não têm demonstrado o desenvolvimento dessas capacidades.

Os resultados das avaliações feitas pelo Saeb têm mostrado que os alunos conseguem resolver apenas questões rotineiras, relacionadas à aplicação direta de conceitos e a mecanização de fórmulas (PAVANELLO, ANDRADE, 2002). Esses resultados revelam que os professores de Matemática, quando abordam os conteúdos geométricos, priorizam os tipos de questões de aplicação de conceitos e de fórmulas em sala de aula.

Assim, buscando a melhoria do ensino e aprendizagem da Geometria nos anos finais do Ensino Fundamental, foi desenvolvido no ano de 2015 um projeto de ensino, dentro do Programa de Licenciatura da Universidade Federal da Paraíba - PROLICEN/UFPB, intitulado "O ensino-aprendizagem da Geometria nos anos finais do Ensino Fundamental: Propostas metodológicas em atividades didáticas”, coordenado por uma professora e com a participação de uma aluna bolsista e uma voluntária do curso de Licenciatura em Matemática, UFPB/Campus IV. O referido projeto teve como objetivo principal propor, aplicar e avaliar atividades e sequências didáticas para o ensino-aprendizagem da Geometria nos anos finais do Ensino Fundamental, utilizando diferentes materiais didático-pedagógicos.

Como parte integrante desse projeto, foi realizada uma investigação acerca dos conhecimentos e habilidades geométricas adquiridas pelos alunos de quatro turmas do 6으o ano do Ensino Fundamental, dos turnos matutino e vespertino de uma escola pública do município de Mamanguape/PB (SILVA, SILVA, SOUZA, 2015a). Foi aplicando um instrumento denominado Atividade Diagnóstica, para mapear os conhecimentos e as dificuldades desses alunos acerca de alguns conteúdos de Geometria para o $6^{\circ}$ ano do Ensino Fundamental. Os resultados desse diagnóstico mostraram que a maioria dos alunos investigados não apresentou as habilidades plenamente desenvolvidas ao final dos anos iniciais do Ensino Fundamental, elencadas pelos Parâmetros Curriculares Nacionais (BRASIL, 1997).

Com base nos dados coletados nesse diagnóstico, foi realizado um planejamento para a elaboração e execução das atividades didáticas na escola, no âmbito do projeto, em três das quatro turmas que participaram da investigação.

As atividades didáticas buscaram contemplar as orientações dos Parâmetros Curriculares Nacionais de Matemática para o Ensino Fundamental (BRASIL, 1998) e tiveram como base o livro didático utilizado pelas turmas (PROJETO ARARIBÁ, 2010), adaptando algumas atividades para levar uma proposta de abordagem que visou explorar as experiências trazidas pelos alunos de suas vivências diárias, considerando também as dificuldades apresentadas por estes alunos (SILVA, SILVA, SOUZA, 2015b). Em seguida, realizamos um trabalho em sala de aula, em conjunto com a professora de Matemática das turmas, utilizando diferentes materiais didático-pedagógicos (vídeos, jogos didáticos, material concreto, instrumentos de desenho geométrico, embalagens e objetos, entre outros).

Ao final das aulas desenvolvidas nas turmas utilizamos o mesmo instrumento, Atividade Diagnóstica, aplicado no início da pesquisa, com o objetivo de investigar os conhecimentos e habilidades geométricas adquiridas pelos alunos ao final da intervenção didática realizada nas três turmas.

Dessa forma, o presente texto tem por objetivo discutir o processo e os resultados desse estudo diagnóstico final realizado com os 94 alunos das três turmas de $6^{\circ}$ ano do Ensino Fundamental, participantes das atividades didáticas realizadas em sala de aula, e que também responderam a Atividade Diagnóstica inicial.

\section{METODOLOGIA DA INVESTIGAÇÃO}

O objetivo da reaplicação da Atividade Diagnóstica foi investigarmos os conhecimentos adquiridos pelos alunos durante as semanas da intervenção didática. Esse instrumento contém oito questões ilustradas, abertas e fechadas, que versam sobre conteúdos da Geometria, tais como: reconhecimento de figuras planas e não planas, classificação de sólidos em poliedros e corpos redondos, planificação de sólidos geométricos, localização espacial. 
A 1 a questão da atividade diagnóstica consistiu na classificação de 13 figuras geométricas, identificadas de "A" a "M", em dois grupos: "Figuras planas" e "Figuras não planas". O objetivo dessa questão foi verificar se os alunos sabem identificar as diferenças entre figuras bidimensionais e tridimensionais.

A $2^{\text {a }}$ questão se resumiu em identificar entre quatro planificações, dispostas nos itens (a), (b), (c) e (d), qual corresponderia à figura de um bumbo, apresentado na questão, que tem o formato cilíndrico. 0 objetivo dessa questão foi averiguar se os alunos têm conhecimento acerca de planificações de algumas figuras tridimensionais, nesse caso do cilindro.

A 3 ${ }^{a}$ questão compreendeu identificar entre quatro grupos de figuras geométricas planas, dispostas no que foi chamado de "caixa", enumeradas de 1 a 4, qual deles seria utilizado montar uma pirâmide de base quadrada, apresentada na questão. Essas contêm triângulos e quadriláteros (retângulos e quadrados) ou apenas quadriláteros. 0 objetivo dessa questão foi sondar se os alunos reconhecem quais figuras planas que compõem as faces da pirâmide de base quadrada.

A 4⿳a questão consistiu na associação da nomenclatura de quatro polígonos (1- Quadrado, 2- Pentágono, 3Triangulo, e 4-Hexágono) a sua forma geométrica, ao número de lados, e ao número de ângulos, que estão distribuídos em uma tabela de três colunas. Essa questão teve como objetivo analisar se os alunos conseguem associar as características de um polígono: nome, forma geométrica, números de lados e número de ângulos.

A 5 ${ }^{\mathfrak{a}}$ questão estava composta por uma tabela com figuras de quinze objetos do cotidiano e que devem ser associadas às formas de sólidos geométricos: prisma, pirâmide, cone, cilindro, esfera, círculo, circunferência, que estão enumerados de 1 a 7, respectivamente. 0 objetivo dessa questão foi saber se os alunos associam objetos geométricos de seu cotidiano ao nome de sua forma geométrica.

A 6a questão compreendeu a apresentação de oito imagens de sólidos geométricos, identificados de " $A$ " a "H", que devem ser separadas em dois grupos: "Poliedros" e "Corpos redondos". O objetivo dessa questão foi saber se os alunos identificam os sólidos de cada um dos grupos, reconhecendo as características que diferem um do outro.

A 7 a questão estava constituída por um mapa de uma sala de aula que contem três fileiras de alunos, enumeradas da parte inferior para a superior como "fila 1", "fila 2", "fila 3". Cada fileira contém três alunos. O mapa contém também três pontos de referência: "a porta da sala", "o lugar do professor" e "o quadro". Essa questão teve como objetivo verificar se os alunos conseguem localizar no espaço a posição de alunos no mapa, a partir de pontos de referência dados nos enunciados: item (a) na fila 3, o aluno mais distante e o mais próximo do professor; e item (b) na fila 1, o aluno mais distante da porta.

Por último, a $8^{\underline{a}}$ questão continha um pequeno mapa de um bairro com quatro ruas: Rua das Camélias, Rua dos Prados, Rua das Palmeiras e Rua das Laranjeiras, algumas paralelas, perpendiculares e concorrentes entre si. 0 objetivo dessa questão foi averiguar se os alunos têm conhecimento dos conceitos de retas paralelas e perpendiculares. Para tanto, a questão apresenta três itens: no item (a) os alunos devem identificar a rua que é paralela à Rua das Camélias; o item (b) requer que os alunos identifiquem a rua perpendicular à Rua das Palmeiras; no item (c) os alunos teriam que identificar a rua que se cruze com a Rua das Palmeiras, mas que não fosse perpendicular a ela.

A Atividade Diagnóstica final foi aplicada a 94 alunos do 6a ano (A, B e C) do Ensino Fundamental. As turmas A e B são do turno matutino e a turma $\mathrm{C}$ do turno vespertino, todas tinham a mesma professora de Matemática.

Na Atividade Diagnóstica inicial, por nossas recomendações, os alunos que a responderam não se identificaram, diferentemente da segunda Atividade que foi preciso a identificação para estabelecer uma nota aos alunos, solicitada pela professora das turmas, logo não foi possível avaliar o desenvolvimento individual dos alunos, comparando uma Atividade com a outra.

Assim como a primeira Atividade, para analisar as respostas, identificamos cada aluno pela letra A (de aluno), seguida de um número. Na turma A temos do A1 ao A35; na turma B temos do A36 ao A69 e na turma C temos do A70 ao A94.

\section{RESULTADOS E DISCUSSÃO}

Apresentamos os dados coletados na Atividade Diagnóstica final por meio de tabelas, destacando a questão, as turmas, e os tipos de respostas (correto, parcialmente correto, errado e em branco), e os valores absolutos e relativos de alunos em cada categoria de respostas. Foram utilizados os mesmos 
critérios de correção da Atividade inicial: para serem consideradas "corretas", as respostas deveriam se apresentar certas e coerentes com o solicitado no enunciado. Já as respostas consideradas "parcialmente corretas" necessitavam ter no mínimo $60 \%$ de acertos, para o caso da $1^{a}$, 4 $\stackrel{a}{a}$, 5a e $6^{\underline{a}}$ questões. Foram consideradas "erradas" as respostas que estavam incoerentes com relação ao solicitado no enunciado, as que não atingiram a quantidade mínima de acertos (60\%) ou as que apontaram mais de uma resposta.

Na 1a questão os alunos precisariam classificar as 13 figuras em "planas" e "não planas". A resposta foi considerada correta se os alunos classificaram todas as figuras corretamente; parcialmente correta se acertaram no mínimo 3 de 5 figuras planas e 5 de 8 figuras não planas; e errada se a resposta encontrou-se inversa ou não terem atingido a quantidade mínima de acertos. A Tabela 1 a seguir mostra as respostas dos alunos para essa questão.

Tabela 1 - Respostas da 1ํㅜ questão

\begin{tabular}{|c|c|c|c|c|c|c|c|c|}
\hline \multirow[t]{2}{*}{ Turmas } & \multicolumn{2}{|c|}{ Correto } & \multicolumn{2}{|c|}{$\begin{array}{l}\text { Parcialmente } \\
\text { correto }\end{array}$} & \multicolumn{2}{|c|}{ Errado } & \multicolumn{2}{|c|}{ Em branco } \\
\hline & № & $\%$ & № & $\%$ & № & $\%$ & № & $\%$ \\
\hline $60 \mathrm{~A}$ & 23 & 65 & 03 & 9 & 09 & 26 & 00 & 0 \\
\hline $60 \mathrm{~B}$ & 03 & 9 & 08 & 23 & 13 & 38 & 10 & 29 \\
\hline $6 \div \mathrm{C}$ & 19 & 76 & 01 & 4 & 05 & 20 & 00 & 0 \\
\hline Total & 45 & 48 & 12 & 13 & 27 & 28 & 10 & 11 \\
\hline
\end{tabular}

Nessa questão, observamos que a maioria dos alunos apresentou um bom desempenho. Das respostas parcialmente corretas percebemos que os alunos, em sua maioria, acertaram as 05 "figuras planas", mas ainda acrescentaram "figuras não planas" em suas respostas. Das 12 respostas parcialmente corretas, 09 delas adicionaram a esfera como figura plana, e pode ser que os alunos, como na primeira atividade, não tenham percebido os meridianos destacados, que indicam a tridimensionalidade da figura, por ser da mesma cor do círculo.

A respeito das 27 questões erradas, em 15 delas os alunos separaram a figura do círculo, do cilindro e da esfera das demais figuras as agruparam em "figuras planas", e os sólidos geométricos em "figuras não planas". Pode ser que os alunos tenham interpretado que precisariam classificar em "poliedros" e "corpos redondos", já que eles separaram todos que apresentam a forma circular. Observamos que alguns alunos trocaram totalmente as "figuras planas" por "figuras não planas", visualizando que existem diferenças entre essas figuras, mas não sabem identificar o nome do grupo à qual elas pertencem quando as figuras estão desenhadas; observamos também que alguns alunos classificaram aleatoriamente as figuras, mostrando que ainda não conseguem identificar as diferenças entre elas quando as figuras estão desenhadas.

Na 2 ${ }^{\text {a }}$ questão os alunos deveriam identificar qual a planificação do bumbo, que tem o formato cilíndrico. A resposta foi considerada correta se o aluno assinalou corretamente a planificação e considerada errada se assinalou outra planificação ou marcou mais de uma opção. As respostas dos alunos para essa questão seguem na Tabela 2 .

Tabela 2 - Respostas da $2^{\underline{a}}$ questão

\begin{tabular}{|c|c|c|c|c|c|c|}
\hline \multirow{2}{*}{ Turmas } & \multicolumn{2}{c}{ Correto } & \multicolumn{2}{c|}{ Errado } & \multicolumn{2}{c|}{ Em branco } \\
& № & \% & № & \% & № & $\%$ \\
\hline 6ㅇ A & 34 & 97 & 01 & 3 & 00 & 0 \\
\hline 6 B & 17 & 50 & 09 & 26 & 08 & 23 \\
\hline 6ㅇ C & 20 & 80 & 05 & 20 & 00 & 0 \\
\hline Total & 71 & 75 & 15 & 16 & 08 & 8 \\
\hline
\end{tabular}

Fonte: Atividade Diagnóstica Final

É possível perceber que a maioria dos alunos acertou essa questão. Das 15 respostas erradas, 11 delas, os alunos assinalaram a opção (a), que é a planificação de um cone e observamos que, assim como na primeira atividade, uma parcela dos alunos pode ter assinalado essa alternativa por ter observado a figura e interpretado que só haveria a parte de cima do bumbo (circular) já que no objeto real em questão ela é a que aparece em evidência, o mesmo pode ter ocorrido nesta segunda atividade, pois ao analisarmos o 
instrumento do A40, percebemos que, ao assinalar essa alternativa, complementou com a justificativa: "arredondado por cima e circular de lado", ou seja, ele não imaginou que a parte de baixo do bumbo existia para comparar com o vértice da planificação do cone, então inferimos que isso pode ter influenciado na hora de escolher a sua planificação. A outra parcela das respostas erradas os alunos assinalaram entre as alternativas (b) e (d).

$\mathrm{Na}$ 3a questão os alunos necessitavam identificar corretamente qual "caixa" que apresenta as figuras planas e que poderiam ser usadas para montar a pirâmide de base quadrada. A resposta foi considerada correta se foi escrita a "caixa" com as peças fundamentais (quadrado e quatro triângulos) e errada se foi escrita uma diferente ou mais de uma opção de "caixa". As respostas para essa questão encontram-se na Tabela 3 a seguir.

Tabela 3 - Respostas da 3a questão

\begin{tabular}{|c|c|c|c|c|c|c|}
\hline \multirow{2}{*}{ Turmas } & \multicolumn{2}{|c|}{ Correto } & \multirow{2}{*}{$\begin{array}{c}\text { Errado } \\
\text { № }\end{array}$} & \multicolumn{3}{|c|}{ Em branco } \\
\hline & № & $\%$ & & $\%$ & № & $\%$ \\
\hline $6^{\circ} \mathrm{A}$ & 33 & 95 & 01 & 2 & 01 & 2 \\
\hline $60 \mathrm{~B}$ & 16 & 47 & 08 & 23 & 10 & 29 \\
\hline $6^{\circ} \mathrm{C}$ & 22 & 88 & 03 & 12 & 00 & 0 \\
\hline Total & 71 & 75 & 12 & 13 & 11 & 11 \\
\hline
\end{tabular}

Fonte: Atividade Diagnóstica Final

Nessa questão, podemos perceber que a maioria dos alunos apresentou um ótimo desempenho. Além de essa questão apresentar uma facilidade maior, como foi abordado na análise da primeira atividade diagnóstica, pelo fato de que nessa questão as figuras planas que representam as faces do sólido são mais rapidamente identificáveis (quadrilátero e triângulo) e estão mostradas separadas, os alunos apresentaram também um bom desempenho em sala de aula, durante as atividades de ensino, com o assunto de figuras planas, planificações, e visualizaram com facilidade as formas das faces dos sólidos. Das 12 questões erradas, 08 delas os alunos marcaram a "caixa" 1 que também continham triângulos e quadriláteros, mas que ao invés de quadrados eram retângulos e três triângulos, ao invés de quatro e como a figura estava desenha, os alunos não prestaram atenção nas diferenças.

$\mathrm{Na} 4 \underline{\text { a }}$ questão os alunos precisavam associar a nomenclatura dos polígonos com sua forma, o número de lados e o número de ângulos correspondentes. As respostas foram consideradas corretas se as três colunas estavam associadas corretamente; parcialmente correta se no mínimo duas colunas estivessem associadas corretamente; errada se a quantidade mínima de colunas não estivesse associada corretamente ou se foram marcados símbolos diferentes do que foi pedido. Na Tabela 4 estão os resultados obtidos para essa questão.

Tabela 4 - Respostas da 4⿳亠丷a questão

\begin{tabular}{|c|c|c|c|c|c|c|c|c|}
\hline \multirow[t]{2}{*}{ Turmas } & \multicolumn{2}{|c|}{ Correto } & \multicolumn{2}{|c|}{$\begin{array}{l}\text { Parcialmente } \\
\text { correto }\end{array}$} & \multicolumn{2}{|c|}{ Errado } & \multicolumn{2}{|c|}{ Em branco } \\
\hline & № & $\%$ & № & $\%$ & № & $\%$ & № & $\%$ \\
\hline $6^{\circ} \mathrm{A}$ & 29 & 83 & 00 & 0 & 06 & 17 & 00 & 0 \\
\hline 60 B & 10 & 29 & 00 & 0 & 22 & 65 & 02 & 6 \\
\hline $6^{\circ} \mathrm{C}$ & 21 & 84 & 01 & 4 & 03 & 12 & 00 & 0 \\
\hline Total & 60 & 64 & 01 & 1 & 31 & 32 & 02 & 2 \\
\hline
\end{tabular}

Nessa 4o questão, a maioria dos alunos conseguiu associar corretamente a figura, mas também apresentaram um número significativo de erros. Na resposta que foi considerada parcialmente correta, o aluno enumerou corretamente apenas a coluna do formato dos polígonos e do número de lados, demostrando que ainda desconhece sobre ângulos. Do total de 31 respostas erradas, 22 delas demostraram confusão entre o pentágono e o hexágono e pode ser que esses alunos não tenham fixado a questão da nomenclatura dos polígonos, e essa foi a maior dificuldade, nas atividades desse assunto, durante a intervenção.

Na 5 $5^{\text {a }}$ questão os alunos deveriam associar 15 (quinze) imagens de objetos, dispostos em uma tabela, ao nome de sólidos geométricos que representam as formas desses objetos. As respostas consideradas corretas foram as que associaram corretamente todos os objetos; parcialmente correta se foram 
associados corretamente no mínimo 09 (nove) dos 15 objetos; e errada se todos os objetos foram associados incorretamente ou abaixo da quantidade mínima de acertos. A seguir estão os resultados para essa questão, expostos na Tabela 5.

Tabela 5 - Respostas da 5a questão

\begin{tabular}{|c|c|c|c|c|c|c|c|c|}
\hline \multirow[t]{2}{*}{ Turmas } & \multicolumn{2}{|c|}{ Correto } & \multicolumn{2}{|c|}{$\begin{array}{l}\text { Parcialmente } \\
\text { correto }\end{array}$} & \multicolumn{2}{|c|}{ Errado } & \multicolumn{2}{|c|}{ Em branco } \\
\hline & № & $\%$ & № & $\%$ & № & $\%$ & № & $\%$ \\
\hline $6^{\circ} \mathrm{A}$ & 24 & 68 & 06 & 17 & 50 & 14 & 0 & 0 \\
\hline $60 \mathrm{~B}$ & 00 & 0 & 12 & 35 & 18 & 53 & 04 & 11 \\
\hline $6^{\circ} \mathrm{C}$ & 15 & 60 & 04 & 16 & 06 & 24 & 00 & 0 \\
\hline Total & 39 & 41 & 22 & 23 & 29 & 31 & 04 & 4 \\
\hline
\end{tabular}

Nessa questão, foi possível perceber que os alunos demostraram uma melhora significativa, num total de 39 respostas corretas ao contrário da Atividade inicial, em que nenhum aluno acertou por completo a questão. Das 22 respostas parcialmente correta em 09 delas os alunos erraram apenas 01 dos 15 objetos apresentados na questão, alguns deles assinalaram o cone com a alternativa "pirâmide" e o círculo e a alternativa "esfera". Das respostas erradas, a maioria delas apresentou dificuldades com a questão dos prismas e pirâmides, círculo e circunferência e algumas até assinaladas aleatoriamente.

$\mathrm{Na} 6^{\mathrm{a}}$ questão os alunos deveriam agrupar os 08 sólidos geométricos em poliedros e corpos redondos. A resposta foi considerada correta se os alunos agruparam todos os sólidos corretamente; parcialmente correta se acertaram no mínimo 02 dos 03 corpos redondos e 03 dos 05 poliedros; e errada se na resposta o agrupamento estava invertido ou se não atingiu a quantidade mínima de acertos. As respostas para a $6^{\underline{a}}$ questão seguem na Tabela 6.

Tabela 6 - Respostas da 6ª questão

\begin{tabular}{|c|c|c|c|c|c|c|c|c|}
\hline \multirow{2}{*}{ Turmas } & \multicolumn{2}{|c|}{ Correto } & \multicolumn{2}{|c|}{$\begin{array}{l}\text { Parcialmente } \\
\text { correto }\end{array}$} & \multicolumn{2}{|c|}{ Errado } & \multicolumn{2}{|c|}{ Em branco } \\
\hline & № & $\%$ & № & $\%$ & № & $\%$ & № & $\%$ \\
\hline $6^{\circ} \mathrm{A}$ & 20 & 57 & 06 & 17 & 09 & 25 & 00 & 0 \\
\hline $6^{\circ} \mathrm{B}$ & 09 & 26 & 07 & 21 & 09 & 26 & 09 & 26 \\
\hline $6^{\circ} \mathrm{C}$ & 17 & 68 & 06 & 24 & 02 & 8 & 00 & 0 \\
\hline Total & 46 & 49 & 19 & 20 & 20 & 21 & 09 & 9 \\
\hline
\end{tabular}

Tabela 6 - Respostas da 6ª questão

\begin{tabular}{|c|c|c|c|c|c|c|c|c|}
\hline \multirow[t]{2}{*}{ Turmas } & \multicolumn{2}{|c|}{ Correto } & \multicolumn{2}{|c|}{$\begin{array}{l}\text { Parcialmente } \\
\text { correto }\end{array}$} & \multicolumn{2}{|c|}{ Errado } & \multicolumn{2}{|c|}{ Em branco } \\
\hline & № & $\%$ & № & $\%$ & № & $\%$ & № & $\%$ \\
\hline $60 \mathrm{~A}$ & 20 & 57 & 06 & 17 & 09 & 25 & 00 & 0 \\
\hline $60 \mathrm{~B}$ & 09 & 26 & 07 & 21 & 09 & 26 & 09 & 26 \\
\hline $6^{\circ} \mathrm{C}$ & 17 & 68 & 06 & 24 & 02 & 8 & 00 & 0 \\
\hline Total & 46 & 49 & 19 & 20 & 20 & 21 & 09 & 9 \\
\hline
\end{tabular}

Nessa questão, nas respostas parcialmente corretas, alguns alunos agruparam corretamente os "poliedros", mas adicionaram o corpo redondo C e, do mesmo modo, outra parcela de alunos também agrupou corretamente todos os "corpos redondos", mas foram adicionados também os poliedros F e G ou apenas um deles, assemelhando-se a Atividade inicial, em que o formato meio "esférico" ou "circular", dos poliedros $F$ e G, pode ter influenciado na resposta dos alunos. Nas respostas erradas, alguns alunos classificaram nos "corpos redondos" apenas a esfera, adicionando o cilindro e o cone no grupo dos "poliedros".

Também encontramos erros como desenhos de figuras planas no espaço de respostas e algumas respostas demostraram que os alunos classificaram sem ter uma noção mais aprimorada de distinção entre os dois grupos. Alguns alunos também trocaram por completo as duas opções, expondo assim que enxergaram a 
diferença entre os dois grupos, mas não souberam classificá-los corretamente, assim como na questão 1. Foi surpreendente o número de erros nessa questão, mesmo não sendo a maioria, pois o assunto de Poliedros e Corpos redondos foi o mais frisado dentro das salas de aula durante a intervenção.

Na 7̣ questão os alunos precisavam identificar a localização de alunos em um mapa da sala de aula, vista de cima. Nos itens (a) e (b), os alunos teriam que localizar alunos em determinado ponto da sala de aula de acordo com uma referência oferecida na questão. No item (a) a resposta é considerada correta se identificar corretamente os 02 alunos solicitados; parcialmente correta se 01 dos 02 for identificado corretamente; errada se os 02 alunos não forem identificados corretamente. 0 item (b) é considerado correto se o aluno for identificadocorretamente, caso contrário estará errado. Na Tabela 7 segue os resultados obtidos para essa questão.

Tabela 7 - Respostas da 7̣a questão

\begin{tabular}{|c|c|c|c|c|c|c|c|c|c|}
\hline \multirow[t]{2}{*}{ Turmas } & \multirow[t]{2}{*}{ Itens } & \multicolumn{2}{|c|}{ Correto } & \multicolumn{2}{|c|}{$\begin{array}{l}\text { Parcialmente } \\
\text { correto }\end{array}$} & \multicolumn{2}{|c|}{ Errado } & \multicolumn{2}{|c|}{ Em branco } \\
\hline & & № & $\%$ & № & $\%$ & № & $\%$ & № & $\%$ \\
\hline \multirow[t]{2}{*}{$6 \div \mathrm{A}$} & (a) & 26 & 74 & 04 & 11 & 03 & 9 & 02 & 5 \\
\hline & (b) & 31 & 89 & 00 & 0 & 02 & 5 & 02 & 5 \\
\hline \multirow[t]{2}{*}{$6 \div \mathrm{B}$} & (a) & 11 & 32 & 08 & 23 & 05 & 15 & 10 & 29 \\
\hline & (b) & 13 & 38 & 00 & 0 & 11 & 32 & 10 & 29 \\
\hline \multirow[t]{2}{*}{$6 \div \mathrm{C}$} & (a) & 18 & 72 & 04 & 16 & 03 & 12 & 00 & 0 \\
\hline & (b) & 20 & 80 & 00 & 0 & 05 & 20 & 00 & 0 \\
\hline Total & & 119 & 126 & 16 & 17 & 29 & 31 & 24 & 25 \\
\hline
\end{tabular}

Como podemos observar na Tabela 7, nessa questão os alunos também se saíram melhor comparados à primeira Atividade, com exceção da turma do 6으 $\mathrm{C}$ que apresentou uma quantidade de erros e respostas em branco ainda maior. Nas respostas consideradas erradas, os alunos cometeram o mesmo erro de atenção, considerando as filas na posição vertical e não na horizontal, como mostra a imagem contida na questão, mostrando que esses alunos não compreenderam a noção de direcionamento.

Na $8^{\text {a }}$ questão os alunos precisavam identificar nos itens (a), (b) e (c) quais as ruas que são paralelas, perpendiculares e concorrentes entre uma e outra. A resposta de cada item foi considerada correta se as ruas foram identificadas corretamente, caso contrário as respostas estão erradas. A Tabela 8 a seguir apresenta as respostas dos alunos para essa questão.

Tabela 8 - Respostas da 8a questão

\begin{tabular}{|c|c|c|c|c|c|c|c|}
\hline \multirow{2}{*}{ Turmas } & \multirow{2}{*}{ Itens } & \multicolumn{2}{|c|}{ Correto } & \multicolumn{2}{|c|}{ Errado } & \multicolumn{2}{|c|}{ Em branco } \\
\hline & & № & $\%$ & № & $\%$ & № & $\%$ \\
\hline \multirow{3}{*}{$6^{\circ} \mathrm{A}$} & (a) & 22 & 62 & 12 & 34 & 01 & 3 \\
\hline & (b) & 21 & 60 & 13 & 37 & 01 & 3 \\
\hline & (c) & 22 & 62 & 12 & 34 & 01 & 3 \\
\hline \multirow{3}{*}{$6^{\circ} \mathrm{B}$} & (a) & 07 & 21 & 15 & 44 & 12 & 34 \\
\hline & (b) & 08 & 23 & 17 & 50 & 09 & 26 \\
\hline & (c) & 07 & 21 & 15 & 44 & 12 & 34 \\
\hline \multirow{3}{*}{$6^{\circ} \mathrm{C}$} & (a) & 16 & 64 & 09 & 36 & 00 & 0 \\
\hline & (b) & 18 & 72 & 07 & 28 & 00 & 0 \\
\hline & (c) & 15 & 60 & 10 & 40 & 00 & 0 \\
\hline \multicolumn{2}{|c|}{ Total } & 136 & 144 & 110 & 117 & 36 & 38 \\
\hline
\end{tabular}

Nesta última questão, os alunos demostraram um ótimo desempenho, comparado ao primeiro. Dos alunos que responderam à questão, 30 (trinta) deles acertaram os três itens simultaneamente, ao contrário da primeira avaliação que de todos os 130 alunos que responderam, apenas 03 (três) acertaram simultaneamente. Das respostas erradas, muitos alunos confundiram o "perpendicular" com o "paralelo", trocando a resposta dos dois itens, mostrando assim que entenderam a noção desses assuntos, mas sentem dificuldades na nomenclatura dos mesmos, pois houve muitos acertos quando a questão era direcionada a "retas concorrentes". 
Após a aplicação da Atividade Diagnóstica final foi possível verificar que mesmo diante das dificuldades encontradas durante o tempo da intervenção na escola, obtemos resultados muito positivos, se comparados aos resultados da Atividade Diagnóstica inicial.

Com relação ao reconhecimento de figuras planas e não planas, embora alguns alunos ainda confundissem algumas figuras, o resultado correto foi bastante satisfatório. Um resultado que ainda apresentou um expressivo número de erros foi associar a nomenclatura dos polígonos com sua forma, o número de lados e o número de ângulos correspondentes. Embora as atividades propostas tenham buscado trabalhar esses assuntos com significação, observamos que os alunos apresentaram bastantes dificuldades. Em relação à classificação de sólidos em poliedros e corpos redondos, e a associação das figuras às nomenclaturas, percebemos que os alunos tiveram um bom desempenho, diferentemente aos primeiros resultados encontrados. A respeito da planificação de sólidos geométricos, os alunos demonstraram compreensão na associação do sólido e sua planificação. Finalmente, sobre a localização espacial, tiveram um desempenho bastante satisfatório, em relação aos resultados iniciais.

Percebemos que em uma das três turmas avaliadas os resultados das duas atividades diagnósticas foram menos satisfatórios do que em relação às outras duas turmas. Essa foi a turma em que o nosso trabalho foi mais dificultoso, pois a turma possuía alunos indisciplinados e menos participativos, e isso pode ter refletido no resultado obtido.

Reconhecemos, também, que tal resultado pode ter sido oriundo de nossa (bolsista e voluntária) inexperiência ao lidar com situações de adversidade, e também da metodologia desenvolvida, pois aplicamos a mesma metodologia em todas as salas, quando poderíamos ter desenvolvido atividades diferenciadas na turma com maior dificuldade de atenção e compreensão, tendo em vista que essa turma tinha um desenvolvimento diferente das outras. Esse fato nos alertou para que sejamos mais sensíveis ao desempenho diferenciado de cada aluno.

Ter um contato com alunos e sua realidade, durante o tempo da intervenção, nos levou a uma reflexão sobre quão grande é o nosso desafio de nos tornarmos profissionais conscientes dos elementos inerentes ao processo ensino-aprendizagem da Matemática, de como podemos nos preparar para as futuras responsabilidades diante de uma sala de aula.

\section{REFERÊNCIAS}

[1] Brasil. Parâmetros Curriculares Nacionais: Matemática. 1o e 2ociclos. Brasília: MEC/SEF, 1997.

[2] Brasil. Parâmetros Curriculares Nacionais: Matemática. 3o e 4ociclos. Brasília: MEC/SEF, 1998.

[3] Pavanello, R. M; Andrade, R. N. G. Formar professores para ensinar geometria: um desafio para as licenciaturas em Matemática. Educação Matemática em Revista, São Paulo/SP, ano 9, n.11. Edição Especial, p. 78-87, abr. 2002.

[4] Projeto Araribá. Matemática: 6º ano. 3. ed. São Paulo: Editora Moderna, 2010.

[5] Silva, G. R. P; Silva, L. C; Souza, C. F. Resultados de uma investigação sobre conhecimentos geométricos de alunos do 6o ano do Ensino Fundamental. In: II Congresso Nacional de Educação - Conedu, 2015, Campina Grande/PB. Anais... Campina Grande/PB, 2015a.

[6] Silva, G. R. P; Silva, L. C; Souza, C. F. Aplicação de atividades didáticas para o ensino-aprendizagem da Geometria:relato de experiências. In: IV Semana da Matemática - UFPB/Campus IV, 2015, Rio Tinto/PB. Anais... Rio Tinto/PB: UFPB, 2015b. 


\section{Capítulo 13}

\section{Ensino da matemática no século XXI: Desafios e possibilidades}

\section{Maria de Fátima Caldas de Figueirêdo}

Resumo: 0 objetivo deste trabalho é apresentar os primeiros resultados de uma pesquisa sobre o uso de recursos digitais no ensino da Matemática, identificando a importância da inclusão da tecnologia no processo de ensino e aprendizagem da referida disciplina, refletindo a utilização dos jogos, considerados um dos recursos digitais favoritos dos alunos, apontados como ferramenta metodológica, sendo um importante aliado do professor da educação básica, devido seu caráter lúdico. A pesquisa teve uma abordagem qualitativa com utilização de questionário online respondidos por professores que ensinam Matemática e pesquisa bibliográfica com aporte teórico que dialogam com a temática. Os dados coletados inicialmente evidenciam a dificuldade de alguns professores em trabalhar com recursos digitais em sala de aula.

Palavras-chave: Ensino da Matemática. Recursos digitais. Jogos. 


\section{INTRODUÇÃO}

A importância da utilização de recursos digitais no ensino da Matemática como facilitador da aprendizagem é encontrada, em geral, nos livros ou textos didáticos. Mas na prática pedagógica, essas ferramentas não se referem apenas a entretenimento. Os recursos digitais nos processos de ensino e de aprendizagem tem uma grande validade, se usada pelo seu caráter desafiador, pelo interesse do educando e pelo objetivo proposto pelo professor.

A utilização dessas ferramentas tecnológicas como proposta pedagógica, deve ser inserida no planejamento disciplinar como subsídio eficiente ao alcance de um objetivo. Nesse sentido, considerar os recursos digitais como mediador no processo de ensino e aprendizagem, é necessário planejamento do professor que possibilite o aluno construir seu próprio conhecimento, evitando dessa forma o processamento de uma mera reprodução de conteúdo entre professor e aluno.

Sendo perceptível a dificuldade enfrentada pelos alunos em Matemática, desde conceitos mais simples a situações problemas mais complexas. E nessa perspectiva que se reflete a utilização dos recursos digitais nas aulas da referida disciplina, pois se acredita nas suas contribuições para uma aprendizagem significativa ${ }^{14}$ e mais compatível com as necessidades atuais. Sendo que o uso consciente e planejado das tecnologias auxilia na formação do aluno com habilidade de aplicar seus conhecimentos na sua vida pessoal, social e profissional.

As seções seguintes apresentam uma reflexão sobre o ensino da Matemática no que se refere aos desafios e possibilidades do século XXI, assim como, algumas considerações sobre os jogos enquanto recursos digitais. Em seguida é apresentado o percurso metodológico com os passos utilizados para a realização da pesquisa e sua análise. Na sequência são retratados os resultados e discussões, onde são representados também por meio de gráficos para uma melhor compreensão do leitor, finalizando com a apresentação das conclusões, empreendidas a partir do estudo bibliográfico e dos primeiros dados obtidos na pesquisa.

\section{ENSINO DA MATEMÁTICA: ALGUMAS CONSIDERAÇÕES}

A forma de construção do conhecimento em pleno século XXI não deve seguir uma prática tradicional, em que o professor é apenas o transmissor de conhecimentos e de informações. Desse modo, com a chegada das tecnologias isso não é mais admissível no processo de ensino e aprendizagem, já que a informação não está mais centrada nas mãos do professor como foi considerado por muito tempo, mas sim, acessível a qualquer momento a todos. Tendo o docente um novo papel de mediador do conhecimento, possibilitando aos discentes uma aprendizagem significativa.

Conforme Onuchic; Allevato (2004), sempre houve muita dificuldade para se ensinar e aprender Matemática. Apesar disso, todos reconhecem a importância e a necessidade da Matemática para compreender os acontecimentos e as relações em sociedade. Não apenas nas áreas exatas, como suas aplicações no cotidiano, desde uma interpretação de gráfico em um jornal até compreensão de simples descontos promocionais.

Nesse sentido, é inaceitável que nas escolas ainda persevere o uso de métodos pedagógicos retrógrados, em que apenas se ensina e aprende por meio da memorização, sem materiais de ensino para além do quadro e do giz. É observado que o ensino da Matemática tem passado por mudanças, visto que os atores envolvidos nesse processo também mudaram. Mas, apesar dessas transformações é notório ainda a presença de falhas, lacunas existentes que indicam o quanto precisa ser pesquisado a fim de sanar essas dificuldades.

Dar aulas é diferente de ensinar. Ensinar é dar condição para que o aluno construa seu próprio conhecimento. Vale salientar a condição de que há ensino somente quando, em decorrência dele, houver aprendizagem. Note que é possível dar aula sem conhecer, entretanto não é possível ensinar sem conhecer. Mas conhecer o quê? Tanto o conteúdo (matemática) como o modo de ensinar (didática); e ainda sabemos que ambos não são suficientes para uma aprendizagem significativa (LORENZATO, 2006, p. 03).

${ }^{14}$ Aprendizagem significativa conforme a teoria da aprendizagem de David Ausubel. 
Diante do exposto surge a preocupação com a forma do ensino da Matemática e entende-se que os educadores precisam urgentemente buscar metodologias as quais venham integrar suas aulas e despertar interesse nos alunos que convivem constantemente com essa dificuldade de aprendizagem. Sendo importante considerar que aulas motivadoras apoiadas em metodologias que busquem incluir o aluno no processo de aprendizagem, tende a sanar essas dificuldades na referida disciplina.

Para D’Ambrósio (1993) existem quatro características desejáveis em um professor de Matemática:

(i) Visão do que vem a ser a Matemática: a Matemática deve ser vista como uma disciplina de investigação, na qual o conhecimento faz parte de um processo que está em constantes mudanças.

(ii) Visão do que constitui a atividade Matemática: a atividade Matemática pode ser considerada basicamente sob dois elementos, em que o primeiro se refere à utilização da Matemática para resolver problemas no dia a dia; e o segundo elemento é referente à necessidade de modelos de estudo para solucionar problemas.

(iii) Visão do que constitui a aprendizagem da Matemática: é importante que os professores conheçam as teorias que explicam a forma que o conhecimento matemático é construído pelo indivíduo.

(iv) Visão do que constitui um ambiente propício à aprendizagem da Matemática: o ambiente propício para a aprendizagem da Matemática é o que possibilita encorajamento ao aluno a propor soluções, passar a explorar mais possibilidades, levantando hipóteses, justificando seu raciocínio e validando suas conclusões.

É necessário se considerar que estas características devem ser construídas ao longo do processo de formação inicial do docente, isto é, durante o seu curso de licenciatura. Porém, não se pode pensar que apenas este momento de formação seja suficiente, desta forma, essas características se consolidarão também durante a efetiva prática pedagógica e por meio de um processo de formação continuada para o professor se situar no processo de ensino do século XXI.

Lira (2016) apresenta algumas características básicas dos professores para o século XXI, entre elas: ter boa formação inicial; respeitar a diversidade; utilizar as NTICs (Novas Tecnologias da Informação e da Comunicação); atualizar-se com as novas didáticas; planejar e avaliar constantemente; ser mediador que ressignifica o ensino; possuir visão holística, integradora e interdisciplinar. Sendo esses aspectos importantes para o fazer docente, mediante o contexto no qual a escola está inserida e a geração de alunos que hoje frequenta esse ambiente escolar.

Com esse entendimento, o advento das tecnologias trouxe a possibilidade de podermos continuar avançando em relação aos objetivos propostos para o ensino da Matemática, uma vez que podemos associá-los ao trabalho docente.

Tendo a seu dispor os recursos e dominando as técnicas e metodologias, os docentes os utilizam, porque sabem que, aumentando o interesse do aluno, consequentemente aumentam também a motivação e a aprendizagem. E, com isso, diminuem os casos de indisciplina (especialmente aqueles originados pela monotonia das aulas ou pela inatividade do aluno) (ZAGURY, 2006, p. 206).

Pode-se compreender que fazer uso de recursos digitais como um método pedagógico pode ser uma boa estratégia para se ensinar a matemática, pois a tecnologia pode facilitar a aquisição de conceitos matemáticos, contudo, é importante saber de sua importância na aprendizagem do aluno. Ao utilizar os recursos digitais em sala de aula precisam-se estabelecer regras, para que as atividades envolvidas façam com que os alunos desenvolvam o pensamento e suas habilidades. Uma vez que sua utilização torna as atividades da Matemática divertida e o professor precisa utilizar em suas aulas de forma adequada, sempre procurando ter como objetivo o aprendizado do discente.

De acordo com Parra (1996) o mundo é constantemente modificado, sendo que essa mudança ocorre na sociedade como toda, desde aspectos econômicos, sociais, culturais até educacionais. Com isso, é exigido tanto da escola como dos professores e demais profissionais da educação competências que contribuam diretamente para a vida do novo alunado que está chegando ao ambiente escolar. As exigências por uma educação de qualidade vêm sendo cobradas a todo instante pela própria sociedade. E para que os profissionais do ensino de Matemática possam ter condições de tornar possível a construção do conhecimento com qualidade, é de fundamental importância que estejam sempre em formação continuada. 
Com os avanços que ocorreram na tecnologia digital é possível observar que temos uma grande clientela, os alunos, inseridos nessa mudança que vai além de uma simples transfiguração.

Nossos alunos mudaram radicalmente. Os alunos de hoje não são os mesmos para os quais o nosso sistema educacional foi criado. Os alunos de hoje não mudaram apenas em termos de avanço em relação aos do passado, nem simplesmente mudaram suas gírias, roupas, enfeites corporais, ou estilos, como aconteceu entre as gerações anteriores. Aconteceu uma grande descontinuidade (PRENSKY, 2001, p.01).

Para Prensky (2001) atualmente temos dois sujeito distintos envolvidos no processo ensino e aprendizagem, Nativos Digitais os quais o autor considera sendo os alunos de hoje, dos anos iniciais da educação básica ao ensino superior, representando eles as primeiras gerações que cresceram com esta nova tecnologia. E Imigrantes Digitais, os professores, Prensky (2001) aponta aqueles que não nasceram no mundo digital, mas em algum momento de suas vidas, ficou deslumbrado e adotou grande parte dos elementos ofertados da nova tecnologia.

Esse dispare entre aluno e professor gera uma desigualdade que consequentemente reflete na educação. 0 professor não deve simplesmente ignorar essa cenário atual da educação, mas sim criar estratégias para estar a todo o momento em paralelo com essa modernidade digital, pois mesmo com toda a informação ao alcance o docente faz parte desse processo de aprendizagem, desempenhando um importante papel na vida de muitas pessoas que almejam o conhecimento.

A utilização de recursos digitais não é uma atividade isolada, para ser desenvolvida separadamente das aulas regulares, mas sim, deve ser parte integradora do currículo e cuidadosamente planejada para que seja realizada de modo contínuo e ativo ao longo do ano letivo, utilizando conceitos e procedimentos matemáticos que estão sendo desenvolvidos. Sendo que não aprende Matemática de repente, é um processo contínuo, que exige planejamento e tempo.

Segundo Pimenta (2009) as transformações que ocorrem nas práticas escolares são efetivadas na medida em que o professor amplia sua consciência sobre as próprias ações, sejam aquelas da sala de aula ou da escola como um todo. Sendo necessário voltar o olhar para o docente que é o grande protagonista nesse processo de mediação de aluno e conhecimento, que é o responsável pela educação de várias crianças, adolescentes, jovens, homens e mulheres que constituem a nossa sociedade. Sociedade está que está cada vez mais interligada e apropriada das tecnologias da comunicação e informação.

No percurso de todo esse processo de inclusão das tecnologias no sistema educacional precisa ser feita algumas observaç̃̃es no tocante à qualificação dos professores. Conforme o Ministério da Educação (BRASIL, 2001) é necessário superar o desafio da ineficiência da formação inicial, em que a maioria dos professores ou não teve esse tipo de formação relacionada às TIC (Tecnologia da Informação e Comunicação), mesmo em universidades, ou essa formação não foi suficiente para alterar suas concepções em relação ao ensino e à aprendizagem e levá-los à utilização dessas ferramentas. Só a existência das tecnologias e sua presença em massa na escola não garantem eficácia e todo o rendimento que é esperado por parte de toda a sociedade. E por mais que seja estudioso e dedicado, o professor precisa formações que comportem a dificuldade e deficiência da formação inicial.

Tardif (2014) define o saber docente como um saber plural "[...] formado pelo amálgama, mais ou menos coerente, de saberes oriundos da formação profissional e de saberes disciplinares, curriculares e experienciais" (TARDIF, 2014 p. 36). Mostrando dessa forma que o saber docente não é homogêneo, nem ao menos imóvel. Mas repleto de acoplamentos entre diferentes saberes, sem sobreposição, e sim conexões de conhecimentos adquiridos em diferentes contextos que se completam. Tardif (2014) diferencia os saberes disciplinares, curriculares e experienciais, como:

- Saberes disciplinares - refere-se aos sabres sociais definidos e selecionados pela instituição universitária, integrando também a prática docente através da formação inicial e contínua dos professores nas diversas disciplinas oferecidas pela instituição de ensino superior.

- Saberes curriculares - condiz aos discursos, objetivos, conteúdos e métodos sob a forma de programas escolares, que a partir dos quais a instituição escolar categoriza e apresenta os saberes sociais por ela definidos e selecionados como modelos de cultura erudita;

- Saberes experienciais - referem-se aos saberes específicos, baseados em seu trabalho cotidiano e no conhecimento de seu meio, incorporando experiência tanto individual como coletiva sob a forma de habilidades de "saber-fazer e de saber-ser" (TARDIF, 2014; p.39). 
É perceptível que a prática pedagógica cotidiana do professor exige algumas ações que muitas vezes não são aprendidas em sua formação, seja ela inicial ou continuada, e nem nos currículos impostos pela instituição escolar. Esses saberes, produzidos e apropriados ao longo de sua história de vida, em sua prática pedagógica diária, nas relações entre a equipe escolar, alunos, família, comunidade, a escola e sua organização e entre os professores e os seus próprios saberes, são classificados por Pimenta (2009) como os saberes da experiência, ou seja, aqueles advindos da intervenção pedagógica do professor na escola, em suas turmas, na organização do trabalho pedagógico, em sua própria história ao longo da sua vida.

Em relação às diferentes formações, inicial e continuada, no tocante ao uso das TIC nas práticas escolares, é considerado que grande parcela de professores que atuam nas escolas públicas não teve, na sua formação inicial, conteúdos e práticas sobre o uso das tecnologias digitais para a incorporação ao seu trabalho docente, a formação continuada reveste-se de maior importância, pois é a possibilidade que os professores têm em adquirir formação que ocorra dentro das necessidades da escola e de seus alunos (SCHNELL; QUARTIERO, 2009, p 123). A formação continuada permanece como um desafio para o professor, tendo que perceber os diferentes discursos e representações da escola na vida dos alunos, já que as tecnologias digitais iniciaram uma nova era, onde o espaço e os saberes adquiriram novos significados.

Segundo Freire (1996) "[...] ensinar não é transferir conhecimento, mas criar as possibilidades para sua própria produção ou a sua construção" (FREIRE, 1996, p. 47). É necessário ver que os alunos não chegam à escola como folhas em branco, mas com uma variedade de conhecimentos que irá refletir no seu processo de aprendizagem. Esse repertório de leitura, experiência extra sala e vivências do aluno possibilita a produção ou construção do seu conhecimento.

Desempenhando o papel de elo entre o aluno e a Matemática, o professor é automaticamente mediador. Esta mediação não funciona com absolutismo, com imposição de conhecimentos. É importante ressaltar que a ação pedagógica envolve dois polos: o ensino e a aprendizagem, representados respectivamente pelo professor e pelo aluno. Ensinar Matemática pode e deve ser compatível com formar pessoas, onde os professores de Matemática devem ser capazes de selecionar e organizar atividades adequadas para contribuir para o desenvolvimento dos alunos e para o desenvolvimento de uma Matemática acessível para todos.

\section{OS JOGOS COMO RECURSOS DIGITAIS PARA O ENSINO DA MATEMÁTICA}

Como já foi debatido nas seções anteriores, é importante o uso de recursos digitais no ensino da Matemática, sendo que é interessante apresentar de maneira atraente para o aluno por meio de diferentes recursos, como; jogos, software, fotografias, gráficos, tabelas, infográficos, entre outros, com o intuito de incentiva-lo a ter interesse pelo que será estudado, tornando o estudo mais significativo.

Os jogos são um dos recursos digitais favoritos dos alunos, esse recurso que também é didático, é recomendado como ferramenta metodológica, sendo um importante aliado do professor, principalmente na educação básica. Como exemplo, temos os jogos eletrônicos que promovem um deslumbramento muito grande, pois eles proporcionam ao individuo uma personalização, permitindo ao aluno um controle virtual das ações da jogada por meio do aplicativo. Proporcionando momentos prazerosos, que de contrapartida podem sanar algumas dificuldades referentes ao conteúdo durante a aula de Matemática, tornando esse momento mais desafiador e significativo.

Conforme Smole (2007) os erros são sentidos de forma natural nos jogos pelos alunos, sem deixar marcas negativas, proporcionando novos testes, estimulando antecipação e averiguação. Oportunizando o aluno enquanto jogador corrigir quando erra e analisar suas vitórias, desenvolvendo uma auto avaliação. Permitindo o aluno interagir de forma dinâmica com a construção de sua própria aprendizagem, saindo da inércia que muitas vezes está presente nas salas de aula.

É importante direcionar para quem, onde e para qual realidade vamos aplicar os jogos.

A aprendizagem através de jogos, como dominó, palavras cruzadas, memória e outros permite que o aluno faça da aprendizagem um processo interessante e até divertido. Para isso, eles devem ser utilizados ocasionalmente para sanar as lacunas que se produzem na atividade escolar diária. Neste sentido verificamos que há três aspectos que por si só justificam a incorporação do jogo nas aulas. São estes: o caráter lúdico, o desenvolvimento de técnicas intelectuais e a 
formação de relações sociais (GROENWALD; TIMM, 2002, apud LARA, 2011, p. 23).

No jogo, mediante a articulação entre o conhecido e o imaginado, a possibilidade de desenvolvimento cognitivo é bem maior comparado ao ensino tradicional. E isso para os alunos é muito importante, uma vez que é necessário desenvolver no aluno a habilidade de elaborar raciocínio lógico e fazer uso inteligente e eficaz dos recursos disponíveis, para que ele possa propor boas soluções às questões que surgem em seu dia a dia, na escola ou fora dela. Um bom uso de jogos em sala de aula pode proporcionar momentos prazerosos e sanar algumas dificuldades referentes ao conteúdo. Porém a utilização de jogos requer que tenhamos uma noção clara do que se quer explorar no momento da execução e de como realizá-los.

Os jogos exercem um papel importante na construção de conceitos matemáticos por se construírem em desafios aos alunos. (...) os desafios apresentados pelos jogos vão além do âmbito intelectual, relacionado diretamente ao dito "conteúdo escolar", pois, ao trabalhar com jogos, as crianças deparam com regras e envolvem-se em conflitos, uma vez que não estão sozinhas, mas em um grupo ou equipe de jogadores. Tais conflitos são excelentes oportunidades também para alcançar conquistas sociais e desenvolver a autonomia (STAREPRAVO, 2010, p.19).

Nesta percepção, é importante destacar que o jogo como recurso de aprendizagem é indispensável nas aulas de Matemática, e que no contexto escolar deve se integrar ao programa de forma minuciosa, desde o momento de selecionar os jogos que devem ser usados, até determinar os objetivos que se pretendem alcançar com os jogos utilizados e concretizar a avaliação das atividades lúdicas.

De acordo com os PCN's (1998) os jogos podem contribuir com o desenvolvimento de habilidades proporcionando "[...] formação de atitudes - enfrentar desafios, lançar-se à busca de soluções, desenvolvimento da crítica, da intuição, da criação de estratégias e da possibilidade de alterá-las quando o resultado não é satisfatório" (BRASIL, 1998, p.43). 0 jogo por ser desafiante leva os alunos a um momento de distração, que em contra partida deve ser bem planejado, com objetivos definidos. É importante deixar claro para os alunos que nas aulas de Matemática, durante o momento lúdico, eles não estão só jogando, mas sim, aprendendo a referida disciplina por intermédio do jogo.

É perceptível, com isso, que a metodologia com utilização do lúdico pode levar o aluno a motivar-se e favorecer a compreensão do conteúdo. Por isso, o professor precisa estar atento e buscar meios para motivar seus alunos a interagir nas aulas de matemática, e os jogos podem ser uma boa estratégia para favorecer essa interação. Assim, o educador deve proporcionar momentos de interação na turma fazendo com que os alunos possam acreditar no próprio potencial de construir conhecimentos.

Meu papel como professor, ao ensinar o conteúdo $a$ ou $b$, não é apenas o de me esforçar para, com clareza máxima, descrever a substantividade do conteúdo para que o aluno o fixe. Meu papal fundamental, ao falar com clareza sobre o objeto, é incitar o aluno a fim de que ele, com os materiais que ofereço, produza a compreensão do objeto em lugar de recebê-la, na íntegra, de mim. Ele precisa se apropriar da inteligência do conteúdo para que a verdadeira relação de comunicação entre mim, como professor, e ele, como aluno se estabeleça (FREIRE, 1996, p.118).

A aprendizagem do aluno não acontece de forma vertical, mas há várias possibilita para que ele se desenvolva, sendo essa a importância de criar diferentes espaços na sala de aula, como também, abordar os conteúdos de diferentes formas para que o aluno desenvolva suas habilidades cognitivas. Pois, quanto mais estratégias o professor utilizar, mais chance os alunos terão para se identificar com a metodologia e consequentemente aprender.

Para Karnal (2014) um dado permanece mais na memória se vier associado a mais lembranças ou ordenado em sequências com alguma lógica. Em geral, quanto mais intensa e completa a emoção associada à memória, quanto mais variado o universo que eu senti naquele momento, mais estruturada será essa lembrança. 0 Lúdico deve ser utilizado com fins educativos, sendo bem planejado para que o objetivo da aula seja concretizado. 


\section{METODOLOGIA E CONTEXTO DA INVESTIGAÇÃO}

Os resultados apresentados na próxima seção fazem parte dos primeiros dados coletados de uma pesquisa online realizada com um grupo de professores que lecionam Matemática nos anos finais do Ensino Fundamental nas escolas públicas no município cearense de Barro. Os sujeitos selecionados fazem parte de um grupo de docentes que participam de formação continuada ofertada pelo município.

É cada vez mais comum a pesquisa online como instrumento de pesquisa. Conforme Mendes (2009) com os avanços das tecnologias digitais a coleta de dados também atinge outro patamar, em que os sujeitos envolvidos têm acesso à pesquisa num ambiente online, que pode ser acessado a qualquer momento. Como também, o próprio pesquisador tem a possibilidade de acompanhar o andamento da pesquisa à medida que os dados forem sendo fornecidos, fazendo alterações e reajustes no curso da investigação.

A pesquisa online foi realizada por meio de questionário elaborado em enquete disponibilizada no grupo do Whatsapp dos professores participantes da formação continuada acima mencionada, optando pela não identificação dos participantes para evitar qualquer tipo de constrangimento. Segundo Prado e Carrara (2005) o questionário pode ser autoaplicável e, neste caso, ampliam-se bastante as alternativas da sua aplicação: pode ser enviado pelo correio, convencional ou eletrônico, a uma amostra de pessoas; além de poder ser disponibilizado na internet como convite para pessoas com determinadas características responderem. A seguir são apresentadas algumas questões que foram abordadas no questionário relacionadas ao ensino e aprendizagem da Matemática e a utilização de jogos nas aulas da referida disciplina.

\section{RESULTADOS E DISCUSSÕES}

No que se refere o nível de aprendizagem dos alunos em relação à disciplina de Matemática os professores classificaram entre pouco, médio e bom (palavras utilizadas pelos respondentes).

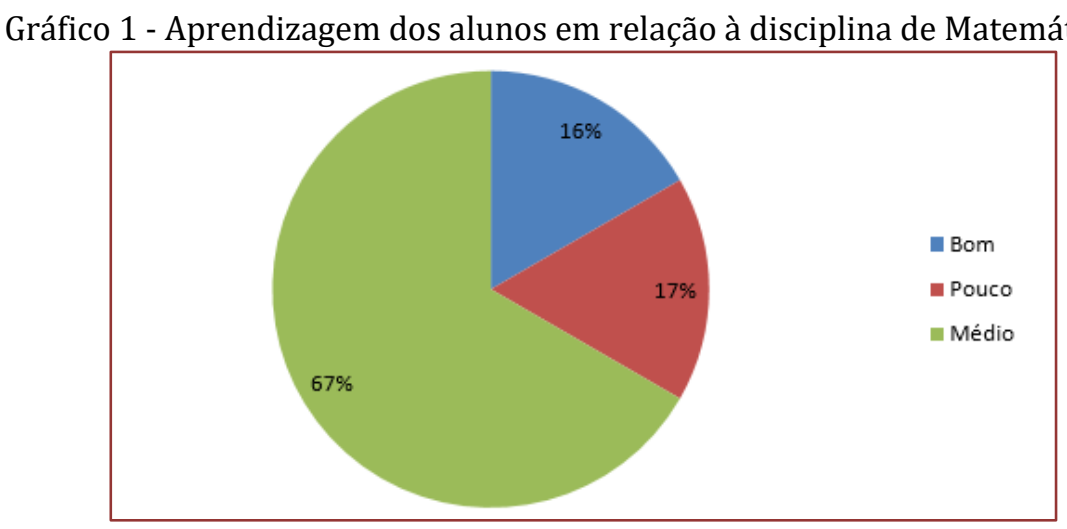

Fonte: Elaborado pelo autor

O gráfico 1 demonstra que dezesseis por cento dos professores consideram bom a aprendizagem dos alunos na disciplina de Matemática. Cerca de sessenta e sete por cento dos professores declaram como médio, e alguns docentes, aproximadamente dezessete por cento acreditam ser pouco a aprendizagem. Confirmando dessa forma com os pesquisadores Onuchic; Allevato (2004) que relatam sobre a dificuldade da aprendizagem em Matemática.

No tocante a recepção dos alunos nas aulas em que é utilizado algum tipo de recurso digital, os professores no geral consideram que o alunado gosta; um docente citou "excelente, a aula fica mais atrativa", outro respondeu "eles gostam muito", teve outra pessoa que comentou "acham interessante". Confirmando com Zagury (2006) que os professores utilizam em suas aulas porque sabem que, aumentando o interesse do aluno, consequentemente aumentam a motivação e a aprendizagem.

Quanto à utilização de jogos dezessete por cento dos docentes consideram difícil utilizar os jogos na versão online. Apoiados na ideia de Prensky (2001) que afirma a existência de muitos professores Imigrantes Digitais, que apesar de não nasceram no mundo digital, adotou muitos ou a maioria dos aspectos da nova tecnologia, incorporando-os na sua prática docente mesmo com dificuldade. 


\section{CONSIDERAÇÕES FINAIS}

A partir do aporte teórico e da pesquisa online é possível observar alguns desafios existentes no ensino da Matemática. Entre eles o trabalho com recursos digitais, como os jogos, citados por alguns professores que mesmo com dificuldade de utiliza-los reconhecem a importância no processo de ensino e aprendizagem da Matemática. Refletindo também, que por meio desses recursos é possível trabalhar com o discente atingindo sua totalidade, percebendo que os motiva, abre espaço para diálogo, oportuniza momentos de socialização do conhecimento, caracterizando uma situação totalmente propícia para o aprendizado.

Foi identificada também a diferença de um jogo pedagógico de outro de caráter apenas lúdico, sendo que o jogo pedagógico desenvolve-se com a intenção de provocar aprendizagem, estimular a construção de um novo conhecimento, fixar e explorar o conteúdo. Já os jogos de caráter apenas lúdico, proporcionam um prazer momentâneo, mas não contribui para uma aprendizagem do discente, se restringe a um brincar sem possibilitar assimilação, fixação e construção de um novo conhecimento.

Destacando também a necessidade da formação continuada para professores como possibilidades para o ensino da Matemática, principalmente formações voltadas para o uso de recursos digitais, uma vez que a pesquisa online e o aporte teórico revela a dificuldade que alguns professores têm em utilizar esses recursos nas aulas de Matemática.

\section{REFERÊNCIAS}

[1] Brasil. Ministério da Educação. Conselho Nacional de Educação. Conselho Pleno. Parecer no 09/CP/CNE/2001. Dispõe sobre as Diretrizes Curriculares Nacionais para a Formação de Professores da Educação Básica, em nível superior, curso de licenciatura, de graduação plena. Brasília: CP/CNE/MEC, 2001.

[2] Brasil. Ministério da Educação. Parâmetros curriculares nacionais: Matemática. Brasília: MEC/SEF, 1998.

[3] D’ambrósio, B. S. Titulado de Formação de Professores de Matemática para o Século XXI: o grande desafio. Pro-posições, v.4, mar.1993.

[4] Freire, P. Pedagogia da autonomia: saberes necessários à prática educativa. 28. ed. Rio de Janeiro: Paz e Terra, 1996.

[5] karnal, L. Conversas com um jovem professor. São Paulo: Contexto, 2014.

[6] lara, I. C. M. Jogando com a Matemática do 6oao 9o ano. São Paulo: Rêspel, 2011.

[7] Lira, B. C. Práticas pedagógicas para o século XXI: a sociointeração digital e o humanismo ético. Petrópolis RJ: Vozes, 2016.

[8] Lorenzato, S. Para aprender matemática. Campinas, SP: UNESP, 2006.

[9] Mendes, C. M. A Pesquisa Online: potencialidades da pesquisa qualitativa no ambiente virtual. Revista digital Hipertextus, n.2, jan.2009.

[10] Onuchic, L. R.; Allevato, N. S. G. Novas reflexões sobre o ensino-aprendizagem de matemática através da resolução de problemas. In: BICUDO, M. A. V.; BORBA, M. C. (Orgs.). Educação Matemática: pesquisa em movimento. São Paulo: Cortez, 2004.

[11] Parra, C. Didática da Matemática. Porto Alegre: Artes Médicas, 1996.

[12] Pimenta, S. G. (Org.). Saberes pedagógicos e atividade docente. 7. ed. São Paulo: Cortez, 2009.

[13] Prado, P. S. T.; Carrara, K.; Omote, S. Versão eletrônica de questionário e o controle de erros de resposta. Estudos de Psicologia, v. 10, n. 3, p. 397-405, 2005.

[14] Prensky, M. Nativos digitais, imigrantes digitais. On the Horizon (NCB University Press), v. 9, n. 5, 2001.

[15] Schnell, $\quad$ R. $\quad$ F.; $\quad$ Quartiero, $\quad$ E. $\quad$ M. $\quad$ A $\quad$ sociedade $\quad$ da informação e os novos desafios para a educação. Revista linhas, v. 10, n. 02, p. 104-126, jan./jun. 2009.

[16] Smole, K. S. Jogos matemáticos do 1ํa ao ano. Porto Alegre: Artmed, 2007.

[17] Starepravo, A. R. Mundo das ideias: jogando com a matemática, números e operações. Curitiba: Aymará, 2010.

[18] Tardif, M. Saberes docentes e formação profissional. Petrópolis: Vozes, 2014.

[19] Zagury, T. O professor refém: para pais e professores entenderem por que fracassa a educação no Brasil. 4.ed. Rio de Janeiro: Record, 2006. 


\section{Capítulo 14}

O surgimento de um jogo didático e suas contribuições na formação de professores: Decimando

\section{Flávia Streva Nunes}

Gabriela Felix Brião

Resumo: Este um recorte de uma pesquisa de monografia do curso de licenciatura em Matemática da Universidade do Estado do Rio de Janeiro. 0 trabalho relata desde o processo de criação de um jogo didático (Decimando) para uma turma de sétimo ano do Ensino Básico até a sua aplicação em uma turma de licenciatura em Matemática, objeto desta pesquisa. 0 estudo aborda a compreensão que o futuro professor tem de números decimais e investiga se, ao jogar o Decimando e fazer as atividades pós-jogo, estes licenciandos apresentam melhora na compreensão do tema. A análise do resultado é feita por três pontos de vista: um teste escrito, o progresso dos alunos durante a pesquisa pela visão da autora e o relato dos próprios estudantes. Discute-se a importância do aprofundamento do estudo de conteúdos da Matemática Básica na formação inicial de professores assim como estimulá-los por meio da própria experiência a conhecerem mais a metodologia lúdica.

Palavras-chave: Matemática Lúdica; Formação de Professores; Jogo Didático; GEMatUERJ. 


\title{
1.INTRODUÇÃO
}

0 trabalho é um recorte de uma monografia de conclusão do curso de Licenciatura em Matemática da Universidade do Estado do Rio de Janeiro (UERJ). Nele é relatado o processo de criação de um jogo didático, denominado Decimando, e uma pesquisa realizada com a aplicação do jogo na formação inicial de professores de Matemática. 0 objeto da pesquisa são alunos de Licenciatura em Matemática da UERJ, na disciplina "Práticas Pedagógicas em Matemática I" do terceiro período do currículo. Na disciplina acontece o aprofundamento do conhecimento pedagógico do conteúdo matemático do Ensino Fundamental II, conciliando Teoria, Prática e Metodologias aplicadas ao Ensino Fundamental.

O objetivo geral desta pesquisa é fomentar a utilização da Matemática Lúdica pelos futuros professores através da própria experiência de construção do conhecimento de forma ativa e significativa. Assim, os licenciandos podem se encorajar a usar essa metodologia ao verem resultados em si mesmos. Gabriela Brião afirma:

\begin{abstract}
"Quebrar paradigmas pode ser uma forma do professor se rebelar contra o que está posto, romper com o sistema instituído e dar voz a sua intuição. Parece certo afirmar que muitos percebem que algo não vai bem na educação matemática escolar. Muitos também não sabem como fazer algo para mudar isto, seguem o fluxo". (BRIÃO, 2015, p.94)
\end{abstract}

Os objetivos específicos vão para além de responder à pergunta de pesquisa, mas também relatar todo um processo de criação e construção de um jogo didático na minha formação inicial como professora.

No Campus Maracanã UERJ, o curso de licenciatura plena em Matemática possui uma estrutura em formato de tripé: a Faculdade de Educação (EDU), responsável pela formação pedagógica geral, o Instituto de Aplicação Fernando Rodrigues da Silveira (CAp-UERJ), responsável pelo conhecimento pedagógico da matemática e o Instituto Básico (IME), responsável pela formação matemática dos licenciandos.

O projeto foi desenvolvido no CAp-UERJ, uma instituição de ensino pública em que sua finalidade é a formação inicial e continuada de professores. 0 colégio é campo de estágio com ambiente propício a atividades de pesquisa em ensino e educação e os professores trabalham de uma forma dinâmica, totalmente diferente do que seria uma aula expositiva, ainda predominante na educação brasileira. Professores do CAp-UERJ tem o diferencial de estarem lecionando na Educação Básica e também formando professores nos cursos de graduação.

A presente investigação apresenta dificuldades de futuros professores de Matemática em relação à compreensão da estrutura de nosso sistema decimal de numeração, principalmente ao trabalharem com submúltiplos da unidade. Os estudantes trabalharam tais dificuldades de maneira lúdica, com o jogo Decimando, e discutiram o tema com auxílio também de outras atividades. Ilydio Sá entende "Lúdico" como:

“ [...] a forma de desenvolver a criatividade, os conhecimentos, o raciocínio de um estudante de todos os níveis, através de jogos, música, dança, teatro, filme, leituras, mímica, desafios, curiosidades, histórias, etc. Nossa proposta, usando o lúdico nas salas de aula, é educar matematicamente, permitindo que o aluno raciocine, descubra e interaja criticamente com colegas e professores". (SÁ, p.1)

0 jogo Decimando foi criado a partir de um erro em um teste diagnóstico de uma turma de sétimo ano do Ensino Fundamental II, do Colégio de Aplicação da UERJ, em 2013. Durante reuniões que aconteciam para discussão do desenvolvimento de um Laboratório de Ensino da Matemática no colégio, o grupo supôs que o erro havia sido causado por uma fragilidade na compreensão do nosso sistema de numeração. Baseado no erro de uma soma com parcelas com submúltiplos da unidade foi criado o jogo como estratégia para trabalhar esse conteúdo específico com eles, aplicado ainda em 2013.

Grando (2000) elaborou uma lista de vantagens e desvantagens que o uso de jogos em sala de aula pode trazer. Algumas das vantagens citadas são: fixação de conteúdos já aprendidos de forma motivadora, introdução e desenvolvimento de conceitos de difícil compreensão, desenvolvimento de estratégias de resolução de problemas, tomada de decisões e saber avalia-las, significação para conceitos aparentemente incompreensíveis, interdisciplinaridade, participação ativa do aluno na construção do conhecimento, desenvolvimento da criatividade, de senso crítico, da participação, da competição "sadia", da observação, das várias formas de uso da linguagem e do resgate do prazer em aprender, alunos de diferentes níveis interagem, os jogos permitem ao professor identificar, diagnosticar erros de aprendizagem e dificuldades. Dentre as desvantagens temos: existe o perigo de dar ao jogo um caráter puramente aleatório quando mal 
utilizado, os alunos jogam e sentindo-se motivados apenas pelo jogo, sem saber porque jogam, o tempo gasto com as atividades de jogo em sala de aula é maior, se o professor não estiver preparado, pode existir um sacrifício de outros conteúdos pela falta de tempo, a exigência do aluno ter que jogar, mesmo que não queira, destruindo a voluntariedade pertencente a natureza do jogo, a perda da "ludicidade" do jogo pela interferência constante do professor, destruindo a essência do jogo.

Na primeira aula de intervenção com os licenciandos, já em 2015, foi feito um teste sobre sistema de numeração e a aplicação do jogo Decimando com a turma aconteceu no encontro seguinte. No terceiro encontro a autora falou sobre nosso sistema de numeração decimal e levou algumas outras atividades, sempre se remetendo ao jogo. Como está apresentado no PCN,

"Recursos didáticos como jogos, livros, vídeos, calculadoras, computadores e outros materiais têm um papel importante no processo de ensino e aprendizagem. Contudo, eles precisam estar integrados a situações que levem ao exercício da análise e da reflexão, em última instância, a base da atividade matemática (PCN, 1997, p. 19)".

No último encontro, aplicou-se o mesmo teste inicial seguido de um breve questionário que buscou compreender a opinião dos licenciandos sobre como a atividade lúdica feita contribuiu para a sua formação como professor e a sua compreensão de números decimais. Mesmo o Decimando tendo surgido como estratégia para uma dificuldade observada em uma turma de sétimo ano que era investigada sob uma perspectiva de professor-pesquisador de seu aluno, para este trabalho utilizou-se o mesmo assunto, os números decimais, em uma turma na formação inicial de professores. A intensão inicial era o amadurecimento do conteúdo e discussão a respeito do jogo para ensino da Matemática.

As ações na turma e análise dos dados buscam responder às perguntas: Qual compreensão os futuros professores de matemática, objetos desta pesquisa, tem de números decimais? Ao jogar o Decimando e fazer atividades pós-jogo, os licenciandos apresentam algum indício de melhor compreensão do tema?

\section{A CRIAÇÃO DO JOGO}

Em 2013 iniciaram-se reuniões no CAp-UERJ visando a discussão e pesquisa em Matemática Lúdica e o desenvolvimento de um laboratório de matemática voltado para a formação de professores da UERJ. Os encontros ocorriam entre uma professora e alunos estagiários de Matemática da instituição e ocorriam discussões de textos ligados a Laboratório de Matemática, Matemática Lúdica e o perfil de professorpesquisador de seu aluno. 0 grupo tinha como campo de pesquisa as aulas de Matemática de uma turma de sétimo ano do CAp-UERJ, regidas pela professora do grupo.

Um teste diagnóstico foi realizado pela turma onde a questão "1,02 +0,8 $=$ _" a maioria dos alunos apresentou a resposta 1,1. Essa questão foi analisada nas reuniões em busca de uma estratégia didática para trabalhar tal erro. De início analisou-se o pensamento do aluno ao dar a resposta 1,1, pois queríamos emergir de seus modelos matemáticos. A hipótese que tínhamos era que, ao aparecer os submúltiplos da unidade, eles consideravam como se todas as ordens dos submúltiplos fossem uma só, somando décimos com centésimos.

Discutindo a respeito, lembrou-se do jogo WAR (jogo de tabuleiro e estratégia, lançado no Brasil pela Grow em 1972) no qual dez peças pequenas (exércitos) equivalem a uma peça grande. As crianças, durante o jogo, costumam fazer as contas com as peças pequenas e grandes sem dificuldade, porém observamos uma dificuldade dos alunos em entender o nosso sistema de numeração decimal. Considerando que os estudantes entendem o sistema de numeração presente em jogos de tabuleiro foi pensado um jogo de tabuleiro onde os alunos teriam que operar aritmeticamente com submúltiplos da unidade. 0 esperado era que os alunos percebessem a diferença entre as ordens e a equivalência de valor entre elas, entender a formação do número, o que acontece na adição e constatar que no Sistema IndoArábico de numeração temos um sistema decimal posicional com o zero.

Problemática posta elaborou-se um tabuleiro com diversas casas com valores em forma decimal e fichas de um inteiro, um décimo, um centésimo e um milésimo. 0 jogador lança o dado e anda a quantidade de casas tirada, ao parar em uma casa do tabuleiro deve pegar no banco as fichas o valor correspondente àquela casa. $\mathrm{O}$ objetivo do jogo é conseguir o maior valor em fichas, visto que o problema era a soma de números decimais.

Com a base do jogo formada, começou-se a pensar nos detalhes. Ainda faltava estimular os jogadores a perceberem a equivalência decimal entre as ordens durante a soma. Nas regras seria possível trocar fichas 
por valores equivalentes. Mais do que ser possível, era preciso fazer com que os jogadores fizessem essas trocas para perceberem o que acontece durante a soma. Como estímulo a isso foi acrescentada a regra que a cada troca feita o participante ganharia mais um inteiro. Foram feitos jogos teste com estagiários de Matemática que frequentavam o CAp-UERJ e com amigos para os ajustes de detalhes.

\section{Figura 1 - Tabuleiro do jogo Decimando}

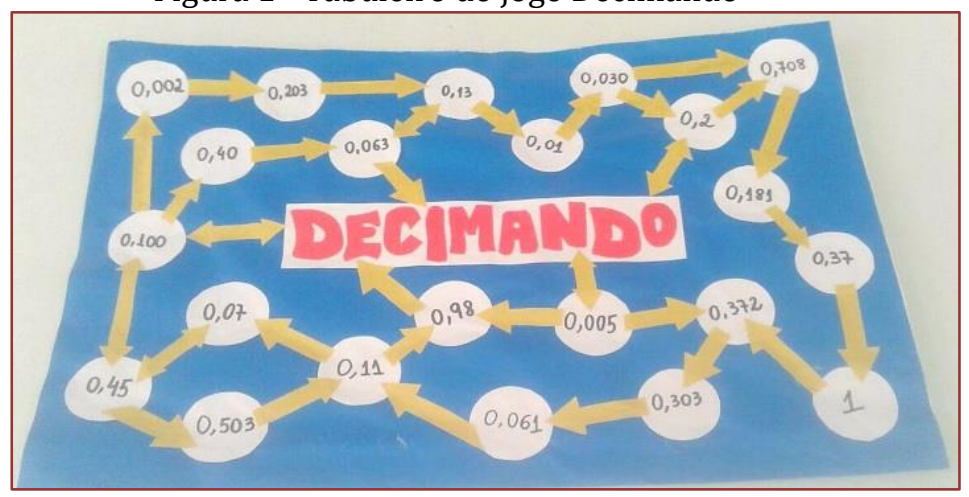

\section{RELATO DO JOGO EM DIFERENTES CONTEXTOS}

A primeira aplicação ocorreu em 2013, na turma de sétimo ano do CAp-UERJ, a qual fez o teste. Os alunos eram interessados durante as aulas de Matemática. Nela havia alunos que levavam a matemática de uma forma fácil tanto como alunos com muita dificuldade na disciplina. A turma dividiu-se em grupos e cada um confeccionou seu próprio jogo, sem saber das regras. Durante a aplicação estavam presentes autoras do trabalho, dois estagiários que já conheciam as regras e outro que aprendeu as regras junto aos alunos. Todos eles observavam e auxiliavam os alunos quando preciso.

Durante a atividade os alunos interagiam, se ajudavam, tiravam suas dúvidas com os estagiários presentes e criavam estratégias na disputa pela vitória. Certo aluno, desatento às regras, ao parar na casa 0,43 quis pegar 43 fichas de um centésimo para poder efetuar a troca para décimos logo em seguida. Ao serem perguntados se este era de sorte ou estratégia, os alunos discutiram entre si e deram como resposta ser um pouco dos dois: sorte ao jogar o dado, porém estratégia para saber qual caminho seguir. Como estratégia alguns escolhiam casas com o maior valor e outros preferiam escolher casas dependendo da quantidade de fichas que já possuíam, sempre atentos as trocas.

Na conversa a turma mostrou ter gostado da atividade, tendo um grupo comentado que iriam produzir um tabuleiro para jogarem em casa, já que os confeccionados ficariam no laboratório do CAp-UERJ. Até então o jogo não tinha nome e um grupo sugeriu "Decimando com Adolfo" (Adolfo era um dos estagiários que acompanhava a turma e estava presente no dia), e toda a turma votou no nome "Decimando".

Na reunião seguinte o grupo aprimorou o jogo para um melhor aproveitamento didático. Foi feita uma tabela para registro, já que o professor não consegue estar em todas as mesas ao mesmo tempo, além de facilitar a formalização da matemática envolvida no jogo. A tabela possui o valor da casa onde o jogador parou, a quantidade de cada ficha pega e o momento que as trocas foram feitas. Outra alteração foi nas fichas, diferenciando-as também por cores e seu valor por extenso.

Em 2014 o mesmo teste diagnóstico foi apresentado para outra turma de sétimo ano. Já divididos em grupos, a questão "1,02 +0,8 = _ teve dois como resposta da maioria da turma. 0 perfil da turma era totalmente diferente da trabalhada no ano anterior. Na classe havia alunos que agiam de forma desrespeitosa durante as aulas, tendo um comportamento inadequado ao meio escolar. No momento do jogo o comportamento se manteve o mesmo, tendo alunos que não se dispuseram nem a ouvir as regras do jogo e aproveitaram para fazer confusão. Os alunos interessados tiraram proveito da atividade, interagindo e suprindo suas dúvidas, porém esta atitude foi de poucos.

Querendo ampliar o alcance dos benefícios que o jogo poderia atingir, o grupo de matemática lúdica do GEMat-UERJ levou o jogo para divulgação científica em eventos de Educação Matemática, tanto por meio de relatos de experiência, como em oficinas. Nesses eventos, o jogo esteve em contato com professores de diversas localidades do Estado, tanto em formação inicial quanto já atuantes no Ensino Básico. Com uma 
dinâmica participativa, os professores jogavam e discutiam sobre o jogo, os pontos positivos e os negativos, possíveis adaptações e melhorias.

O jogo também foi aplicado em um projeto do Programa Institucional de Bolsas de Iniciação à Docência (Pibid), em 2014, que desenvolve um laboratório de Matemática em uma escola pública do Rio de Janeiro. O Decimando foi produzido pelos bolsistas e aplicado com uma turma de sétimo ano. Ao confeccionar os tabuleiros, o grupo de bolsistas pensou em uma nova disposição para as casas do jogo (versão atual). Os frequentadores do laboratório eram alunos em seu contra turno, sem nenhuma exigência ou bonificação na nota, frequentavam apenas pelo prazer de estarem ali. Cerca de dez alunos jogaram o Decimando. Esse número de alunos no laboratório foi fundamental para a aplicação ter dado certo, pois os estudantes estavam com muitas dúvidas em como formar cada número e na questão das trocas e assim foi possível dar atenção e explicar a cada grupo o sistema de numeração decimal.

Com o objetivo de incentivar um maior engajamento dos professores de Matemática do Estado do Rio de Janeiro com a Matemática Lúdica e levar o trabalho feito no grupo do Laboratório de Matemática para fora dos muros do CAp-UERJ, o Projeto de Extensão "Jogos didáticos: trazendo o lúdico para a sala de aula" visita escolas públicas com um dia de oficinas de jogos. Nas turmas do Fundamental II houve dificuldade principalmente para entenderem como formariam os números já que só tinham como opção um décimo, um centésimo, um milésimo e um inteiro de fichas. Essa dificuldade também apareceu no Ensino Médio, porém menos intensa. Observou-se que para uma atividade onde se tem aproximadamente uma hora com os alunos e diversas atividades em revezamento, não compensa usá-lo se já não há um certo conhecimento prévio de decimais. Pois nesse caso, os alunos usam tanto tempo ao tentar montar o número que não aproveitam o jogo e não houve oportunidade para auxiliá-los.

\section{DECIMANDO NA FORMAÇÃO INICIAL DE PROFESSORES}

O jogo Decimando foi levado a uma turma de Práticas Pedagógicas em Matemática I, matéria de terceiro período do curso de licenciatura em Matemática da UERJ. Elaborou-se um teste para os licenciandos, buscando ver como eles entendiam o nosso sistema de numeração decimal. Mais do que saber se os estudantes dominavam as operações com os números em sua forma decimal, o intuito era ver se dominavam o que representa cada algarismo que o compõe. 0 primeiro encontro com a turma foi a aplicação do teste. Durante a correção duas questões em especial chamaram mais atenção: a questão 5, que perguntava quantos centésimos possui o número 0,320 e que nenhum dos alunos presentes respondeu de forma correta; e a questão 6, que dado uma certa quantidade de décimos, centésimos e milésimos em um número era necessário completar uma tabela e escrever o número representado. Após a correção, o foco da pesquisa veio a ser às questões recém citadas. Na aula seguinte foi levado o jogo para aplicação e mais três alunos, ausentes no encontro anterior, fizeram o teste antes de jogarem.

Dividida em três grupos a turma leu as regras, tiraram dúvidas e começaram a jogar. Observou-se que alguns alunos da turma dominavam o conteúdo e tiravam as dúvidas dos outros jogadores. Foi pedido que caso houvesse um responsável por dar as fichas, que fosse feito o pedido de quantas de cada por cada participante. Nessa hora as dúvidas começaram a aparecer. Ao pedir, usavam o vocabulário "número inteiro, vírgula, parte decimal" e com um pedido para que pedissem pelo nome da ficha eles se forçaram a falar os nomes das ordens. No início os jogadores hesitavam um pouco em falar e olhavam para as fichas parar garantirem que usariam a palavra certa, mas, depois de um tempo já passaram a pedir com mais rapidez e segurança.

Alguns jogadores tiveram dificuldade em saber como montariam os números do tabuleiro com as fichas do Decimando. Os participantes do grupo ajudavam os que estavam mais inseguros e os explicavam caso pedissem por fichas erradas. As casas “ 0,40 ” e “ 0,030 ” foram as que trouxeram mais questionamentos. Jogadores pediram quarenta fichas de um décimo no primeiro exemplo e trinta fichas de um centésimo no segundo exemplo citado. Esse erro apareceu diversas vezes, tanto no Ensino Básico quanto no Ensino Superior. Após dez rodadas contou-se a pontuação para ver quem ganhou em cada tabuleiro. Cada jogador foi instruído a contar o valor das fichas que possuía, anotar na tabela, e depois fazer a soma no papel do valor das casas onde parou durante o jogo, anotassem e entregassem a tabela. Das onze tabelas de registro, os resultados das contas com o valor das fichas não eram iguais em $55 \%$ delas.

As dúvidas que apareceram durante o jogo confirmaram a necessidade de se trabalhar com números decimais com a turma. Para os professores ensinarem uma Matemática sem regras aparentemente sem sentido, é preciso que este entenda o sistema de numeração, estando claro o que isso representa e sem vícios de linguagem que acabam dificultando o entendimento. A etapa seguinte consistiu em uma aula para 
a turma de licenciatura usando o jogo como referência. Esta foi a primeira vez que se preparou uma aula remetendo atividades ao Decimando. A aula continha atividades com números em sua forma decimal com situações trazidas do jogo e outras que os alunos pudessem interagir de uma forma dinâmica. 0 planejamento fluiu tão bem que precisou dos quatro tempos de aula (três horas). Escolheu-se três atividades diferentes para dinamizar: as fichas do jogo, o material dourado e as mãos. A aula começou com uma questão similar à do teste que perguntava quantos centésimos um número possuía. Colocando as opções de resposta no quadro se viu as alternativas dos erros dos alunos no teste. Deixei a questão no canto do quadro com as alternativas e continuei com o planejamento, para que depois das atividades voltássemos para dar a resposta após as atividades. Todos em sala de aula estavam participando das atividades e interagindo. A turma se dividiu em dois grupos e foi pedido para efetuarem somas utilizando o material dourado, as fichas do jogo e as mãos, (onde cada um do grupo era uma ordem diferente dos números nas operações). Após resolverem nos grupos eles apresentavam as resoluções para todos da sala de aula. Uma conta de divisão foi colocada no quadro e pedi a ajuda da turma para que me explicassem como eles faziam a operação. 0 intuito dessa atividade era observar se eles entendiam o passo a passo "oculto" no algoritmo usado para a divisão.

A cada etapa da divisão foi escrito a lado o que o processo significava, e a resposta dos licenciandos para a parte inteira foi rápida. Porém, ao restar uma unidade na divisão por quatro simplesmente falaram "Coloca o zero do lado do um no resto, a vírgula no quociente e continua fazendo a conta". Questionou-os o porquê do acrescimento do zero seguido da vírgula no quociente. Houve um momento de silêncio, enquanto pensavam e disseram nunca ter parado para pensar no motivo pelo qual faziam isso, simplesmente o faziam da forma que tinham aprendido. Até que um aluno respondeu: coloca o zero porque estamos transformando a unidade em décimos. Completou-se apenas que se a divisão era de décimos, o resultado seria décimos, logo, precisaríamos colocar a vírgula no quociente.

Em um último momento da aula foi proposto aos estudantes a realizarem a subtração com as fichas do Decimando, e após, usar as fichas, fazer a conta com a dinâmica das mãos. No processo da subtração com as fichas acontece o inverso da adição. Na adição é preciso fazer trocas de dez fichas iguais por uma de ordem maior. Já na subtração, quando não se tem fichas suficientes para retirar em uma ordem, é necessário que se troque uma ficha de uma ordem maior por dez fichas da ordem menor. Ao se depararem com tal situação os alunos pararam para pensar e rapidamente solucionaram o que deveria ser feito. Quando usaram as mãos, perceberam a necessidade de mais uma pessoa para auxiliar na quantidade de dedos de uma ordem. Os futuros professores de Matemática se revezavam para apresentar as atividades feitas.

A última aula da intervenção foi dedicada a aplicação do mesmo teste do primeiro encontro, acrescido de um questionário com perguntas referentes a metodologia lúdica.

\section{RESULTADOS}

Um ponto de vista para analisar a evolução da turma foi a visão das autoras do trabalho. Durante a dinâmica em sala com as atividades foi possível perceber uma melhora significativa por parte dos alunos que apresentaram dificuldade no teste e durante o jogo. Participantes que no início se mostraram confusos em relação aos números decimais, nas atividades já estavam os tratando de maneira mais íntima e apresentando as respostas de forma clara. Os alunos ao final das atividades estavam verbalizando os números decimais da forma correta e natural e operavam rapidamente com as fichas, mãos e material dourado. Mesmo sem uma explicação prévia do que deveria ser feito, os estudantes subtraíram com os materiais utilizados, fazendo as trocas necessárias. Isso mostra que o trabalho feito durante a aula que seguiu o jogo foi fundamental para o amadurecimento em como entendem o nosso sistema de numeração e suas operações.

Para analisar a opinião dos licenciandos, foram levadas em consideração suas falas, respostas no questionamento final e os Resumos Avaliativos de cada aula pedido pela professora regente da turma. Ao final dos testes alguns alunos comentaram positivamente sobre a pesquisa que participaram, dizendo ter entendido melhor o nosso sistema de numeração e algoritmos das operações e por terem feito o mesmo teste com muito mais confiança e com menos dificuldade. Mesmo os alunos que dominavam o conteúdo relataram que a compreensão melhorou, e ao ver o tema de forma diferente, se atentaram a detalhes antes não percebidos. Os relatos traduzem a perspectiva dos futuros professores de matemática de que a pesquisa obteve ganhos para sua compreensão de números decimais e todos gostaram da metodologia lúdica utilizada para abordar o conteúdo, achando válido levar tal metodologia às aulas do Ensino Básico. 
Analisando os testes da segunda aplicação ficou visível uma melhora após a realização das atividades. Todas as questões apresentaram um melhor percentual em relação à primeira aplicação, inclusive com questões tendo $100 \%$ de acerto, o que não aconteceu no primeiro teste. 
Figura 2 - Percentual de acerto dos dois testes

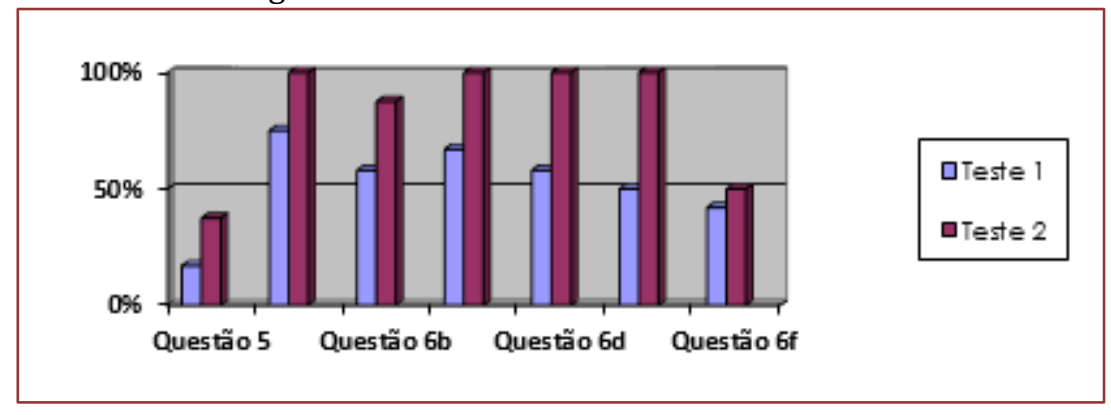

\section{CONSIDERAÇÕES FINAIS}

A pesquisa se iniciou de forma indireta em 2013 com os encontros para discussão de Educação Matemática entre uma professora e estagiários do CAp-UERJ. Nesses encontros foi elaborado o jogo Decimando para uma turma de sétimo ano, sendo aplicado depois em eventos de Educação Matemática e em outras instituições de ensino e séries diferentes, chegando nesse trabalho a formação de professores de Matemática.

A hipótese feita foi de que os alunos da graduação melhorariam o resultado no teste e compreenderiam melhor o sistema de numeração, facilitando o entendimento das operações aritméticas. Outro resultado esperado foi através da própria experiência motivar os alunos futuros professores a usarem a metodologia lúdica em suas aulas. Ao término do trabalho todos os estudantes pesquisados apoiavam o uso da metodologia lúdica nas salas de aula do Ensino Básico. A importância da Matemática Lúdica na formação de professores se torna aqui presente. Trabalhar com essa metodologia no início do curso de graduação dá a oportunidade aos futuros professores de a conhecerem, já que muitos relatam nunca ter jogado em uma aula de Matemática antes, e amadurecerem o compromisso de utilizá-la durante sua formação inicial.

O jogo Decimando, ou atividades com suas fichas, tem espaço para ser usado desde os últimos anos dos anos iniciais até a formação de professores, da Matemática e da Pedagogia, em cada segmento focando em diferentes questões sobre o conteúdo. É possível adaptar as regras e tabuleiro e trabalhar com o jogo com subtração, multiplicação e divisão abrangendo todas as operações básicas. Esta possibilidade emergiu durante esta pesquisa. Os cursos de formação de professores de Matemática precisam dar mais atenção quando se trata do conhecimento que esse professor tem da Matemática Básica, visto nas escolas. Os professores da Educação Básica precisam de um conhecimento profundo da Matemática Elementar.

É importante que, ao utilizar jogos, o professor cite a atividade posteriormente, enquanto trabalha o conteúdo. Relacionar o material do jogo com atividades em sala de aula, para que o aluno perceba que $o$ que jogou está de fato ligado à Matemática e formalizar o que foi visto, é fundamental para não ser apenas o jogo pelo jogo.

\section{REFERÊNCIAS}

[1] Brião, Gabriela F. Algumas insubordinações criativas presentes na prática de uma professora de matemática. In: D’ambrosio, B.; Lopes, C. E. (Orgs.). Ousadia criativa nas práticas de educadores matemáticos. Campinas, SP: Mercado de Letras, 2015, p. 87102.

[2] Grando, Regina. O conhecimento matemático e o uso de jogos na sala de aula. Campinas, SP, 2000. Tese de doutorado. Faculdade de Educação, Universidade Estadual de Campinas - Unicamp

[3] Parâmetros curriculares nacionais : matemática / Secretaria de Educação Fundamental. - Brasília : Mec/Sef, 1997.

[4] www.Magiadamatematica.com, Os jogos e atividades lúdicas nas aulas de matemática da educação básica, SÁ, Ilydio P. de. Acessado em 17 jul 2015. 


\section{Capítulo 15}

\section{Educação financeira nos anos iniciais do ensino fundamental sob o olhar da inclusão}

\section{Barbara Cristina Mathias dos Santos}

\section{Luciana Troca Dantas}

\section{Chang Kuo Rodrigues}

Resumo: Este trabalho integra o Grupo de Pesquisa Investigações no Ensino de Matemática e Ciências e tem como objetivo apresentar um estudo de caso, desenvolvido numa escola municipal de Duque de Caxias, cujos sujeitos são crianças com deficiência intelectual leve e/ou moderada. Como a Educação Financeira reflete na vida social do indivíduo, constatou-se essa abordagem pertinente na prática inclusiva, desde os anos iniciais. A inclusão de pessoas com deficiência faz-se presente em vários setores da atividade humana, até porque é seu direito firmar-se no mercado de trabalho quando adultos. Para tanto, pretende-se observar as leis que tratam dos direitos de aprendizagem da criança com deficiência, relacionar a Educação Financeira ao currículo escolar, para assim, iniciar os primeiros passos na construção dos conceitos de educar financeiramente. Diante disso, este trabalho tem um viés na formação continuada de professores que atuam efetivamente na inclusão, diante de reflexões, discussões e possibilidades de ação.

Palavras-chave: Educação Matemática; Deficiência Intelectual; Educação Financeira; Matemática Inclusiva. 


\section{INTRODUÇÃO}

A Inclusão, no Brasil, está acompanhada de muitas inquietações no que tange às práticas pedagógicas bem como a interação social, nos dias de hoje. A escola, neste sentido, atua em todas as vertentes, trabalhando conteúdos sob as perspectivas atitudinais, conceituais e procedimentais, preconizadas pelos documentos oficiais. Dentre vários temas a serem trabalhados com esse público, podemos destacar o preparo para o exercício da cidadania, aqui, com o sentido da autonomia.

A escola, então, deve agir voltada para a inclusão das pessoas com deficiência, cumprindo as normas previstas na Constituição Federal de 1988 que, em seu artigo art. 205, trata do direito, permanência e atendimento especializado, afirmando categoricamente que "a educação, direito de todos e dever do Estado e da família, será promovida e incentivada com a colaboração da sociedade, visando ao pleno desenvolvimento da pessoa, seu preparo para o exercício da cidadania e sua qualificação para o trabalho." Já no caso do art. 206, "O ensino será ministrado com base no seguinte princípio: I - igualdade de condições para o acesso e permanência na escola" e, por fim, no art. 208: "o dever do Estado com a educação será efetivado mediante a garantia de: III - atendimento educacional especializado aos portadores (sic) de deficiência, preferencialmente na rede regular de ensino." (BRASIL, 1988)

Vale dizer que o termo "portadores" foi devidamente substituído por "pessoas com deficiência", de acordo com a Secretaria de Direitos Humanos, Conselho Nacional dos Direitos da Pessoa com Deficiência, Resolução no 1, de 15 de outubro de 2010.

Nesse sentido, a prática pedagógica no processo da inclusão tem sido um tema recorrente em grupos de estudos e em qualquer ambiente de discussão docente. As dificuldades dos docentes em entender as necessidades individuais do sujeito com deficiência representam o grande desafio na atualidade dentro de uma instituição educacional. Essa problemática aumenta quando se une a ela a preocupação no que diz respeito à perspectiva de futuro desse público, principalmente a inserção no mundo do trabalho, valendo lembrar que a Lei 8.213 de 24 de julho $1991^{15}$ que assegura a garantia de vagas para elas.

Para que se atinja o objetivo em questão é imprescindível que a escola desde cedo trabalhe com a questão da conscientização sobre o uso dos recursos, tanto financeiros quanto ambientais. Sobre essa tomada de consciência, recorremos à Fávero (2011) que considera três aportes particulares: a situação interacional, a análise dos atos da fala e a tomada de consciência no sentido desenvolvimental piagetiano. De acordo com a autora, adotar a análise dos atos da fala produzidos na interação implica em defender um procedimento que, concomitantemente, evidencia a tomada de consciência de cada sujeito e bem como seus processos de regulações cognitivas e metacognitivas, sendo este, realizado por meio da análise dos processos comunicacionais das interações (FÁVERO, 2005 apud FÁVERO, 2011). Para proceder as análises, recorremos a conceitos de Educação Financeira de modo a abordar questões simples do cotidiano, levando o sujeito a pensar nas suas atitudes que envolvem o dinheiro, partindo de temas mais simples para os mais complexos.

Percebemos na sociedade uma preocupação geral sobre o endividamento pessoal, por isso, na expectativa de se garantir uma melhor qualidade de vida no futuro, a Educação Financeira tem recebido destaque nacional e internacional nos últimos anos. Diante disso, conciliar os saberes matemáticos sob a ótica das finanças e a educação inclusiva acaba por convergir em uma prática desafiadora, permitindo ampliar as possiblidades de o educador matemático exercer potencialmente o seu papel no âmbito escolar.

\section{A PESQUISA}

Mais especificamente, esta pesquisa aborda a questão dos alunos com deficiência intelectual leve e/ou moderada como critério de inclusão para os sujeitos da pesquisa, destacando ainda que o projeto desta investigação passou pelo crivo do Comitê de Ética em Pesquisa, sob o número CAAE 51197815.2.00005283. A deficiência intelectual teve seu conceito construído na Convenção da Guatemala, em 2001, no artigo 1o como [...] "uma restrição física, mental ou sensorial, de natureza permanente ou transitória, que limita a capacidade de exercer uma ou mais atividades essenciais da vida diária, causada ou agravada pelo ambiente econômico e social". Durante muitos anos a medida do coeficiente de inteligência (QI) foi utilizada como parâmetro de definição dos casos de deficiência intelectual, estando

15 A chamada Lei de Cotas (Lei 8.213 de 24 de julho 1991) garantiu a inserção de pessoas com deficiência no mercado de trabalho. Atualmente, existem cerca de 306 mil pessoas com deficiência formalmente empregadas no Brasil. Desse total, cerca de 223 mil foram contratadas beneficiadas pela Lei de Cotas, o que comprova a importância da Lei. 
presente inclusive no CID 10 (Código Internacional de Doenças, desenvolvido pela Organização Mundial de Saúde), que ao mencionar o Retardo Mental (F7079), classificando-o entre leve, moderado, grave e profundo, conforme o comprometimento:

- Leve: QI entre 50 e 69 (em adultos, idade mental de 9 a menos de 12 anos). Podendo apresentar dificuldades de aprendizado na escola. Muitos adultos poderão ser capazes de trabalhar e de manter relacionamento social satisfatório e de contribuir para a sociedade.

- Moderado: QI entre 35 e 49 (em adultos, idade mental de 6 a menos de 9 anos). Podendo ocorrer atrasos acentuados do desenvolvimento na infância, mas a maioria dos pacientes aprende a desempenhar algum grau de independência quanto aos cuidados pessoais e adquirir habilidades adequadas de comunicação e acadêmicas. Os adultos necessitarão de assistência em grau variado para viver e trabalhar na comunidade.

- Grave: QI entre 20 e 40 (em adultos, idade mental de 3 a menos de 6 anos). Provavelmente deve ocorrer a necessidade de assistência contínua.

- $\quad$ Profundo: QI abaixo de 20 (em adultos, idade mental abaixo de 3 anos). Devem ocorrer limitações graves quanto aos cuidados pessoais, continência, comunicação e mobilidade.

Cabe ressaltar que é garantido por lei, que o aluno, com deficiência, seja assistido em sua peculiaridade. Para isso, levantamos a questão norteadora desta pesquisa: Como educar financeiramente as crianças na perspectiva da inclusão? Para responder a esta pergunta, a pesquisa tomou como referencial teórico Jean Piaget (1973; 1978a; 1978b) e seus estudos no que tange à epistemologia genética. Na busca de sintetizar a contribuição de Piaget, utilizaremos os apontamentos de Chiarottino (1988) que, segundo o autor, tem um sentido claro: o fato de o sujeito organizar, estruturar e explicar o mundo onde está inserido. Nesse sentido, Chiarottino (1988, p.3) esclarece que: "conhecer não é somente explicar; e não é somente viver: conhecer é algo que se dá a partir da vivência (ou seja, da ação sobre o objeto do conhecimento) para que este objeto seja imerso em um sistema de relações".

Em sua obra, Piaget (1973) propõe, então, uma teoria do conhecimento, em que busca fundamentá-las por meio de critérios especificamente definidos e, cujo objetivo, segundo o autor é:

[...] levar a psicologia a sério e fornecer verificações em todas as questões de fato que cada epistemologia suscita necessariamente; mas substituindo a psicologia especulativa ou implícita, com a qual em geral se contentam, por meio de análises controláveis. (PIAGET, 1973, p. 13)

As observações realizadas por Piaget, durante anos, acompanharam sujeitos da infância até a adolescência, com uso de métodos específicos desenvolvidos pelo próprio autor. A epistemologia de Piaget, na sua própria definição, destaca que não se trata de uma visão positivista e, sim, naturalista, por meio das relações do sujeito com o objeto, na medida em que esse objeto, durante a observação, passa a ter significados diferentes de acordo com o desenvolvimento do sujeito.

Nessa perspectiva, podemos considerar que Piaget apresenta o sujeito em um dinamismo cognitivo, em constante aquisição e transformação das estruturas mentais; para isso, ele apresenta dois conceitos, a saber: assimilação e acomodação. A assimilação, tal como Piaget define, seria a absorção de novos conceitos oferecidos pelo meio aos mecanismos já construídos pelo sujeito, ao passo que, a acomodação, por sua vez, representa as alterações que o sujeito faz intrinsecamente nos esquemas mentais, após uma nova informação, ou seja, um processamento que se comprova por meio de mudança da prática.

Piaget, segundo Kamii (1993), defende outro conceito muito importante para a inclusão: a autonomia. Esse termo estaria diretamente ligado à moral e à ética. Então o professor terá sempre em mente, como objetivo da educação, a promoção da autonomia do aluno. Para Kamii (1993), o principio essencial para o desenvolvimento da autonomia seria o de encorajá-los a debater sobre soluções para problemas sociais. Dessa maneira, ao longo do tempo, essas crianças aprenderiam a decidir o que é melhor para todos os envolvidos.

Nesse sentido, tendo assumido a ideia piagetiana de autonomia e relacionando-a com a matemática, podese pensar o ensino voltado para o desenvolvimento da capacidade da autonomia, quando as crianças aprimoram seu raciocínio e confiança na própria habilidade de raciocinar. Espera-se também que eles se tornem capazes de resolver problemas de formas diferentes e comparem com o pensamento de seus pares. 


\section{OS MEIOS}

O Estudo de Caso, segundo Gilberto Martins (2008) é uma das metodologias mais antigas na investigação científica e tem seu ápice com a publicação da obra de Robert Yin: "Case Study Research: Design and Methods”, consolidando-se uma referência básica para investigações sob este método. A preferência é justificável pela consistência normativa dos procedimentos propostos pelo autor.

Na concepção de Martins (2008), o estudo de caso é uma estratégia metodológica de se fazer pesquisa nas ciências sociais e nas ciências da saúde. Esta metodologia é destinada para avaliar ou descrever situações onde o elemento humano está presente. Ainda em Martins (2008), busca-se compreender uma situação em sua totalidade através de um mergulho profundo sobre o objeto delimitado para estudo.

Para André (1995), Dauster, Tosta e Rocha (2012 apud ALLEGRINI, 2013) o estudo de caso investiga situações bem específicas, singulares, como uma pessoa, um grupo, uma sala de aula, uma cultura etc., contribuindo para a compreensão global de um fenômeno peculiar, sem a pretensão de modificá-las.

Em Educação, o estudo de caso pode ser utilizado como metodologia para as investigações sobre os métodos de aprendizagem de avaliação e de outras práticas educativas. Como instrumento deste trabalho de campo pode citar a análise documental, utilizando, também, diário de campo e entrevistas. (ANDRÉ, 1995; DAUSTER; TOSTA; ROCHA, 2012 apud ALLEGRINI, 2013)

De acordo com Yin (2005), o estudo de caso pode ser entendido como método rigoroso de pesquisa, que usa uma abordagem sistêmica e sociológica, apoiando-se em exemplos concretos. Além disso, o autor ainda sugere que um estudo de caso "atraente" deve reunir algumas características básicas:

Engajamento, instigação e sedução - essas são características incomuns dos estudos de caso. Produzir um estudo de caso como esse exige que o pesquisador seja entusiástico em relação à investigação e deseje transmitir amplamente os resultados obtidos. (YIN, 2005, p. 197). A metodologia do estudo de caso implica, em particular, a existência de uma hipótese prévia, que será testada na aplicação durante a investigação, o que não pressupõe que ela possa inadmitir uma construção de uma nova hipótese a partir dos resultados obtidos na investigação.

Diante dessas reflexões, entendemos que esta pesquisa, que se debruçou no ambiente escolar num contato direto com crianças com deficiência intelectual, tem no estudo de caso, uma metodologia apropriada, aplicada nesse caso, com alunos com deficiência intelectual leve/moderada matriculados em turma regular de ensino de uma escola Pública Municipal em Duque de Caxias, estado do Rio de Janeiro, que verificará a hipótese de que é possível trabalhar educação financeira com crianças com deficiência intelectual.

\subsection{PROCEDIMENTOS METODOLÓGICOS}

Certa dos ganhos decorrentes da Educação Financeira, a sociedade está ao encontro do movimento em defesa da inclusão, sobretudo, no âmbito escolar, e, tratando-se da inclusão de crianças com deficiência percebe-se a necessidade de adaptação de conceitos e atividades.

As atividades desenvolvidas foram selecionadas no sentido de possibilitar o acesso das crianças com deficiência de maneira que não somente se colha dados, mas principalmente se possa oferecer alguma contribuição na formação da autonomia desses alunos. Elas se organizam em dois eixos: 0 Valor das Coisas e Economia \& Sustentabilidade.

O Valor das Coisas Neste eixo será explorado com a criança que todas as coisas têm um valor, mas que existem coisas materiais (que podemos pegar) e imateriais (que não podemos pegar). As coisas materiais são compradas com dinheiro, as imateriais não, mas que são também coisas de muito valor. Outro conceito presente neste eixo é o da necessidade e desejo. Para aprender a consumir com responsabilidade é preciso que a criança seja estimulada a fazer essa reflexão.

Economia \& Sustentabilidade. Existem certas atitudes que se formadas nos anos iniciais de vida do individuo se consolidam para toda a vida. Ensinar uma criança a cuidar de seus objetos estão diretamente ligadas ao comportamento do adulto, que preserva tanto seus bens quanto o patrimônio público, bem como se é ensinado a essa criança a valorizar seu próximo, ela o fará também. Cuidar bem de suas coisas é economizar para se ter. Dentro desse eixo encontra-se também o cuidado com os bens coletivos. É importante que a criança perceba que existem coisas que é para o uso de todos e devem ser preservados. Exemplos possíveis para serem trabalhados na escola são a água, a energia e o papel. Outra reflexão que 
este eixo proporciona é a cooperação e solidariedade. É importante que a criança se desenvolva com a preocupação pelo próximo, isto é, responsabilidade social.

Pequenas atitudes como doar aquilo que não lhe serve mais, já faz o sujeito perceber o que é cooperação e solidariedade. Para início de investigação, aplicou-se um questionário a fim de analisar os conhecimentos prévios da criança. As atividades aplicadas foram adaptadas da coleção "Descobrindo o Valor das Coisas: o guia de educação financeira para pais e professores ensinarem as crianças brincando", de Cerbasi (2012).

Para ilustrar uma atividade pertencente a “O Valor das Coisas”, segue como exemplo na Figura 1.

Figura 1: Atividade do eixo "O Valor das Coisas"

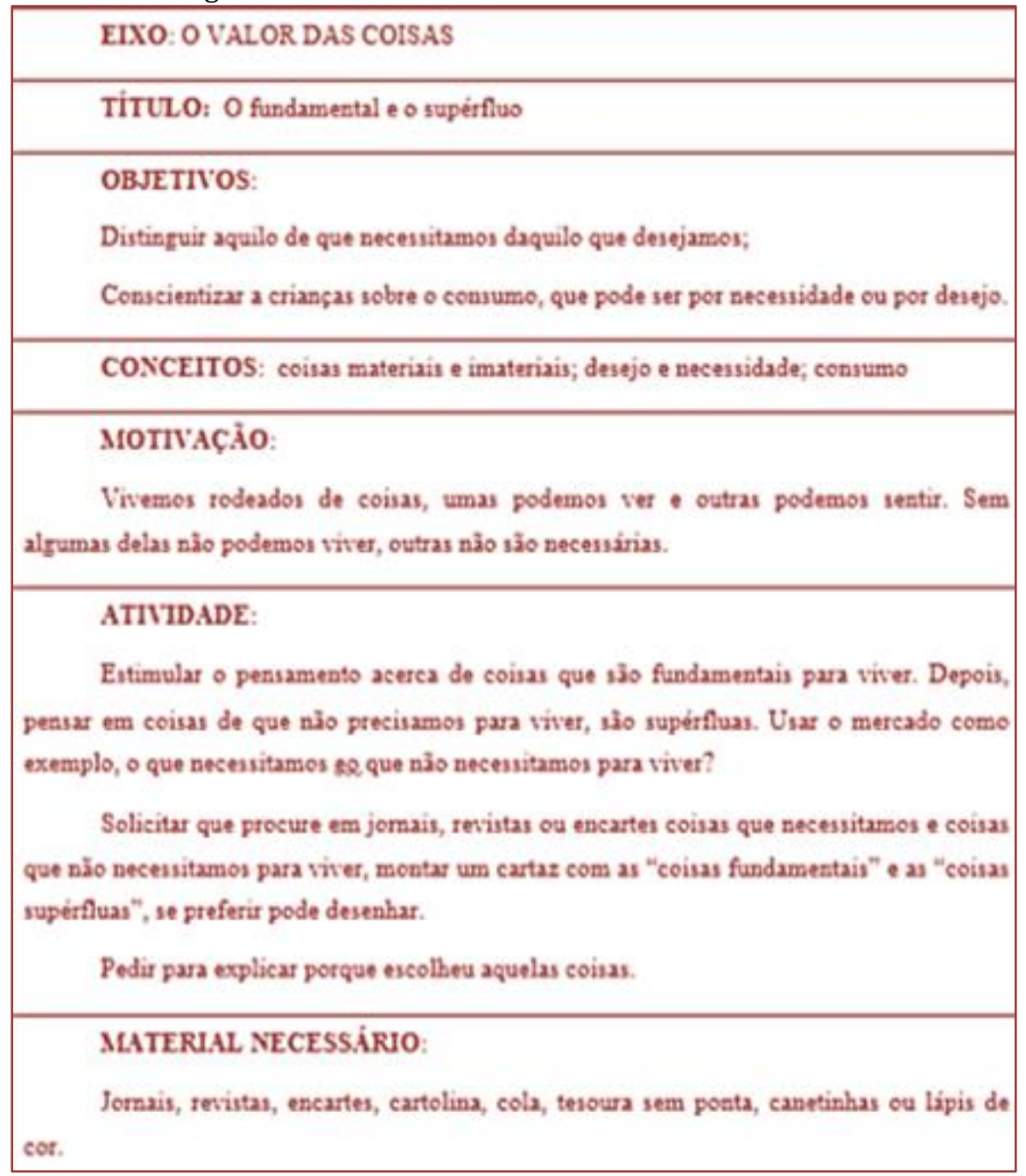

Fonte: Dados da Pesquisa

\section{RESULTADOS}

A presente pesquisa foi aplicada em uma escola pública, no município de Duque de Caxias, com três alunos com deficiência intelectual do Ensino Fundamental que são identificados como D.8, R.10, e J.12. As entrevistas ocorreram individualmente bem como as outras atividades.

Como ilustração, será apresentada a transcrição da entrevista realizada com um dos sujeitos sobre alguns subtemas da Educação Financeira.

P - Pesquisador E - Entrevistado: R. 10 anos

P - Você sabe o que é dinheiro e pra que ele serve?

E- Pra fazer compras.

P- Como o que por exemplo? 
E- Comprar arroz, feijão e batata.

P- Você sabe como faz pra ganhar dinheiro?

E- É só ir no banco tirar

P- Você acha que para ser feliz precisa de muito ou pouco dinheiro?

E- muito

P- Por que? O que você acha que o dinheiro vai fazer a gente ser mais feliz?

E- Comprar material, caderno, estojo.

P-Alguém dá dinheiro para você?

E- minha mãe.

P- E o que você faz com o Dinheiro?

E- Compro caderno, lápis, guaraná.

P- Você ganha dinheiro sempre ou quando merece?-

E - Quando merece.

P- 0 que você faz para merecer?

E- eu lavo louça porque minha mãe ganhou neném.

P- Você tem algum sonho?

E - telefone

P- você sabe que o telefone tem que pagar uma conta todo mês?

E- sei

P- Você acha que vai ter dinheiro para pagar a conta?

E - Nunca

$\mathrm{P}$ - Se você quisesse realizar seu sonho, o que você poderia fazer?

E- Comprar outra coisa, um tablet

P- Um tablet e o telefone precisa de muito dinheiro. Como você pode fazer para conseguir muito dinheiro?

E - É só ir no banco para tirar muito dinheiro.

P- Quem você acha que coloca o dinheiro no banco?

E - O prefeito

P - Você acha importante guardar o dinheiro?

E - sim

P - Você guarda dinheiro? Para que?

E - Comprar um chinelo.

Analisando a intervenção acima apresentada, buscou-se retomar à questão levantada nesta pesquisa: Como educar financeiramente as crianças na perspectiva da inclusão? Nesta entrevista em particular pode-se comprovar que R.10 tem contato com dinheiro dentro da própria casa. Apesar de não demonstrar conhecimento de como a família faz para perceber uma remuneração, em casa, ela sabe que se colaborar com algum serviço será recompensada. Foi possível perceber, que a felicidade para R.10 está ligada aos bens materiais, que neste caso se fez por meio de material escolar. 0 banco para ela, tem significado de muito dinheiro. Citou o sonho de adquirir um telefone mesmo sabendo que não terá recursos para mantêlo em sua função principal (comunicação). 


\section{CONSIDERAÇÕES FINAIS}

A inclusão não se refere a adaptação do sujeito a escola, mas o inverso: a escola se adapta ao sujeito. Nesta adaptação estão embutidos o currículo e os métodos. Assim, esta pesquisa abraça o viés da Educação Financeira como contribuição de uma formação pautada na autonomia desses sujeitos.

Sabendo da necessidade de tempo para a aprendizagem da pessoa com deficiência, a proposta é que se inicie com a temática da Educação Financeira nos anos iniciais do ensino fundamental. As atividades propostas nos procedimentos metodológicos foram permeadas por situações da vida diária dessas pessoas, contextualizando da melhor forma o conteúdo trabalhado.

Por meio do estudo de caso, foram aplicadas a entrevista e as atividades com crianças de 8, 10 e 12 anos, com quadro específico de deficiência intelectual leve/moderada.

Para a análise dos resultados, recorreu-se ao aparato teórico de Piaget quando ele destaca que a aprendizagem é uma construção que se dá de maneira natural, por meio das relações do sujeito com um objeto que pode ainda ter significados diferentes na medida em que o sujeito se desenvolve.

Para se educar crianças com deficiência intelectual financeiramente, é necessário que se utilize atividades com mínima progressão de complexidade, de modo que se diagnostiquem quais relações estes sujeitos já possuem com o objeto de estudo e quais conceitos formados eles tem a esse respeito. Não se deve negar a importância dessa abordagem para este público com especificidades próprias. Espera-se, contudo, após a intervenção que eles se tornem capazes de decidir acertadamente os diferentes problemas não apenas financeiro, mas os de toda uma vida.

\section{REFERÊNCIAS}

[1] André, M. E. D. A. Etnografia da prática escolar. Campinas: Papirus, 1995. Angrosino, M.; Flick, U. (Coord.). Etnografia e observação participante. Porto Alegre: Artmed, 2009. BRASIL. Ministério da Justiça. Coordenadoria Nacional para Integração da Pessoa Portadora de Deficiência. Declaração de Salamanca: linhas de ação sobre necessidades educativas especiais. Brasília: Corde, 1994. __. Ministério da Educação. Secretaria de Educação Média e Tecnológica. Parâmetros curriculares nacionais: ensino médio. Brasília: Mec/Semtec, 1999 Chiarottino, Z. Psicologia e epistemologia genética de Jean Piaget. São Paulo: EPU, 1988. Cerbasi, G.; Sousa, M. Descobrindo o valor das coisas: o guia da educação financeira para pais e professores ensinarem seus filhos brincando. 1 ed. São Paulo: Gente, 2012. Fávero, M. H. A pesquisa de intervenção na psicologia da Educação Matemática: aspectos conceituais e metodológicos. Educar em Revista, v. 1, p. 47-62, 2011. KAMII, C. Aritmética: novas perspectivas-implicações na teoria de Piaget. Campinas, SP: Papirus, 1993. Martins, G. A. Estudo de Caso: uma estratégia de pesquisa. São Paulo: Atlas, 2008. Organização Mundial da Saúde. Classificação Estatística Internacional de Doenças e Problemas Relacionados à Saúde CID-10. Disponível em: <www.datasus.gov.br/cid10/v2008/cid10.ht... Acesso em: 01 nov. 2015

[2] Piaget, J. A Epistemologia Genética. Trad: Nathanael C. Caixeiro. Rio de Janeiro: Vozes, 1973. _. 0 Nascimento da Inteligência na Criança. Trad. Alvaro Cabral, Rio de Janeiro: Zahar, 1978a. __. Psicologia e Epistemologia: por uma teoria do conhecimento. Forense Universitária, 1978b. YIN, Robert K. Estudo de Caso, planejamento e métodos. 2.ed. São Paulo: Bookman, 2001. 


\section{Capítulo 16}

\section{Softwares matemáticos na prática pedagógica: Uma reflexão sobre o uso em escolas públicas}

\section{Ana Cristiane de Sousa \\ Ruth Brito de Figueiredo Melo}

Resumo: A utilização de softwares educativos no ensino da matemática vem tornando as aulas mais atrativas proporcionando aos educandos um aprendizado significativo, diferenciado e contextualizado. Dessa forma, este trabalho foi realizado através de uma pesquisa exploratória e descritiva, com o objetivo de avaliar as potencialidades e limitações da utilização de alguns softwares matemáticos e investigar o uso dos mesmos por parte de alguns profissionais da área nas suas práticas pedagógicas. Para a realização da pesquisa, foi aplicado um questionário aos professores de matemática de quatro escolas públicas de Campina Grande, com enfoque qualitativo e quantitativo, em que os dados obtidos foram tratados em médias utilizando-se o programa Excel. Com base nos resultados encontrados, observamos, no que tange as limitações do uso dos softwares, a falta de incentivo que possibilite uma formação continuada à área específica de cada professor e a precariedade das condições físicas das escolas, bem como a insuficiente quantidade de computadores que atenda a demanda dos alunos; enquanto que as maiores potencialidades se deram para as atribuições de melhor absorção dos conteúdos, troca de informações e experiências entre alunos e professores na obtenção de um maior envolvimento destes.

Palavras-chave: Software matemático, Limitações, Potencialidades. 


\section{INTRODUÇÃO}

Segundo Lourenço (2010), despertar a curiosidade e a motivação nos alunos nem sempre é uma tarefa fácil. Para motivá-los é necessário apresentar os conteúdos como atividades ou experiências enriquecedoras que incentivem o interesse e a curiosidade.

A utilização de softwares educativos no ensino da matemática vem tornando as aulas mais atrativas proporcionando aos educandos um aprendizado significativo, diferenciado e contextualizado (DULLIUS e HAETINGER, 2005).

Portanto, a presente pesquisa tem seu problema ligado as seguintes questões: Quais os obstáculos que geram a resistência ao uso dos recursos computacionais por parte dos professores nas aulas de matemática? Como o uso de novas tecnologias interfere no processo de ensino aprendizagem da matemática?

Softwares, tais como, Geogebra, Excel, Matlab, Poly, trilha matemática 1.0, Math Educator 1.2 e outros, são programas matemáticos que podem ser utilizados para uma melhor explanação dos conteúdos de matemática no dia a dia, inclusive para dinamizar as aulas. Tais programas, citados na pesquisa, podem tornar-se de conhecimento dos professores de matemática como mais uns dos recursos didáticos a serem utilizados em sua prática pedagógica, levando-os a uma reflexão sobre a relevância do uso dos mesmos.

De acordo com Cysneiros (2000), a inserção da informática no ambiente escolar faz-se necessária, permitindo o acesso dos indivíduos a um bem cultural que deveria ser disponível para todos, sendo também imprescindível haver investimento por parte das autoridades governamentais na melhoria da educação pública, que visa à formação de uma geração capaz de competir no mercado de trabalho e, sobretudo, na sociedade globalizada.

Diante do relato, e associado ao interesse em abordar seu contexto no âmbito escolar, este trabalho tem por objetivo avaliar as potencialidades e limitações da utilização de alguns softwares matemáticos e investigar o uso dos mesmos por parte de alguns profissionais da área nas suas práticas pedagógicas.

\section{EMERGÊNCIA DO US O DAS MÍDIAS DIGITAIS NO ENSINO DA MATEMÁTICA}

Para Tedesco (2004, p. 11), A incorporação das novas tecnologias à educação deveria ser considerada como parte de uma estratégia global de política educativa e, nesse sentido, destaca que as estratégias devem considerar, de forma prioritária, os professores, considerando que as novas tecnologias modificam significativamente o papel do professor no processo de aprendizagem e as pesquisas disponíveis não indicam caminhos claros para enfrentar o desafio da formação e do desempenho docente nesse novo contexto.

O professor, por outro lado, consciente de que não consegue alcançar resultados satisfatórios junto a seus alunos e tendo dificuldades de, por si só, repensar satisfatoriamente seu fazer pedagógico, procura novos elementos muitas vezes meras receitas de como ensinar determinados conteúdos que, acredita, possam melhorar esse quadro. Uma evidência disso é, positivamente, a participação cada vez mais crescente de professores em encontros, conferências ou cursos (SANTANA e MEDEIROS, 2014).

0 uso de Tecnologia Informática (TI) em atividades do cotidiano cresce velozmente em toda nossa sociedade, e, em particular, nas escolas. Este fato, aliado a diferentes tipos de ações nas próprias escolas, tem mudado o cenário da educação, oferecendo novas possibilidades de trabalhar as diferentes disciplinas do currículo (ZULATTO,2002).

Dessa forma, o emprego das mídias na Educação Matemática aumenta a capacidade de exploração e descoberta, gerando o aprendizado de conceitos matemáticos envolvidos nas construções em sala de aula, em que os meios digitais podem servir como ferramentas essenciais para a aprendizagem ou pesquisa de conceitos matemáticos (BERNART, 2010).

\section{VANTAGENS E DESVANTAGENS DO USO DE SOFTWARES NO ENSINO DE MATEMÁTICA}

São muito evidentes os sinais da importância do uso do computador nas instituições de ensino. Como qualquer ferramenta educativa, o computador possui vantagens e desvantagens, sendo mais apropriado para algumas aplicações do que para outras, em que verifica-se, a utilização do mesmo não é a resposta para todos os problemas educacionais, sendo indispensável portanto a prevalência das boas práticas que tiveram êxito no sistema educacional, uma vez que depende de qualidades humanas para que ele seja usado de uma forma eficiente (IÉGAS e LUPPI, 2007). 
Através de recursos computacionais podemos oferecer, de maneira rápida, o conteúdo necessário para aprendizagem e estendermos as abordagens passivas utilizadas para o ensino atual, provendo exemplos interativos com animações gráficas que ilustrem o funcionamento de funções, cálculos e construções geométricas, dentre outras áreas. Com a experimentação e o retorno gráfico destas ferramentas, poderemos obter resultados sensivelmente positivos ao ensino de matemática (ISOTANI, SAHARA e BRANDÃO, 2001, p. 02).

Dessa forma, assim como um bom livro-texto não é, por si só, garantia de um bom curso, também um bom software precisa ser bem explorado por professores e alunos para dar bons resultados. Ao contrário do que esperam muitos administradores educacionais o computador não faz milagre (DULLIUS e HAETINGER, 2005).

A inserção de softwares matemáticos como suporte didático se, bem utilizados e direcionados no alcance do objetivo proposto vem contribuir e atuar de forma direta na minimização de diferenças entre as duas realidades, possibilitando assim, a formação de uma escola mais instigante a partir do uso de novas tecnologias de informação e comunicação condizendo com o que pais e alunos de hoje esperam do ensino e da instituição escolar: uma escola moderna, preparada e dinâmica, que estimulam educandos e educadores na construção coletiva e busca do conhecimento, haja vista que o conhecimento é construído na mente do aprendiz.

\section{DIFICULDADES DA IMPLANTAÇÃO DE SOFTWARES MATEMÁTICOS NA PRÁTICA PEDAGÓGICA}

A Matemática, como ciência, sempre teve uma relação muito especial com as tecnologias, desde as calculadoras e os computadores, aos sistemas multimídia e à internet. No entanto, os professores (como, de resto, os próprios matemáticos) têm demorado a perceber como tirar partido destas tecnologias como ferramenta de trabalho. 0 grande desafio que elas põem hoje em dia à disciplina de Matemática é saber se está conseguirá dar uma contribuição significativa para a emergência de um novo papel da escola ou se continuará a ser a parte mais odiosa do percurso escolar da grande maioria dos alunos (DULLIUS e HAETINGER, 2005).

De acordo com Mercado (2002) e Lorenzato (2006, p.52) essas limitações acontecem devido à formação que o professor recebe do curso superior em licenciatura de Matemática, uma vez que favorece estudos e pesquisas direcionadas ao terceiro grau, preterindo a um segundo plano a formação do futuro docente para atuar como professor do ensino fundamental ou médio.

Outro motivo está relacionado à necessidade do domínio de metodologias de ensino, por parte do professor. Não basta a este profissional dominar apenas o uso da informática educativa. Ele precisa aprender a fazer seu planejamento pautado nas possíveis dificuldades dos alunos com relação ao tema da aula. Esse planejamento precisa contemplar também a mediação do professor durante a aula, no sentido de favorecer aos alunos momentos em que possam apresentar suas soluções para eventuais discussões.

Mercado (2002) afirma que as tentativas para incluir o estudo das novas tecnologias nos currículos dos cursos de formação de professores esbarram ainda nas dificuldades com investimento exigido para a aquisição de equipamentos.

\section{METODOLOGIA}

A pesquisa foi desenvolvida em quatro escolas estaduais de ensino fundamental e/ou médio: Irmã Stefanie, Escritor Alceu do Amoroso Lima, Dom Luiz Gonzaga Fernandes e Severino Cabral, localizadas no bairro das Malvinas, Cinza e Bodocongó na cidade Campina Grande -PB. A população foi composta por dez professores de matemática das escolas estaduais citadas acima, durante o período de funcionamento nos três turnos, no período de agosto de 2014.

O projeto foi desenvolvido pela acadêmica do curso de Especialização em Fundamentos da Educação: Práticas Pedagógicas Interdisciplinares, da Universidade Estadual da Paraíba, situada em Campina Grande - PB, e aplicado um questionário com questões de 1 à 11 que teve enfoque qualitativo para que se pudessem analisar melhor as informações fornecidas pelos professores.

Posteriormente, foi realizada uma análise quantitativa em que os dados obtidos foram tratados em médias utilizando-se o programa Excel e qualitativa, utilizando-se triangulação dos dados, objetivando constatar o uso de softwares matemáticos nas práticas pedagógicas. 


\section{ANÁLISE DE DISCUSSÃO DE DADOS}

Após a aplicação do questionário aos professores e professoras que lecionam matemática nas quatro escolas públicas pesquisadas, fizemos a triangulação dos dados coletados transformando em informações as questões que julgaram ser mais relevantes, quanto à construção de novos modelos de ensino na edificação do saber. Partindo desse pressuposto, gráficos e tabelas foram inseridos a fim de discorrermos melhor e de forma mais detalhada os resultados obtidos, como veremos posteriormente. A análise dos dados foi quanti-qualitativa.

Perguntamos inicialmente aos envolvidos na pesquisa, quais os softwares relacionados abaixo seriam de conhecimento de cada professor entrevistado e registramos na Figura 1 a seguir.

Figura 1. Relação de softwares conhecidos pelos entrevistados

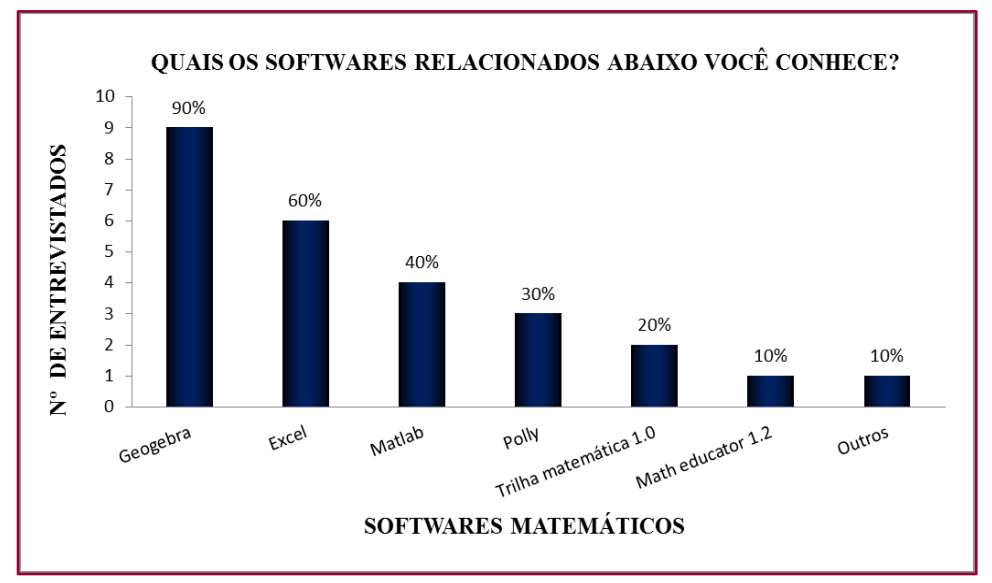

A partir das respostas registradas, observamos que nove dos professores e professoras (90\%) questionados, afirmaram conhecer o software Geogebra, seguidos do excel que representou $60 \%$ dos entrevistados. Via de regra, apenas um dos professores (as) examinados corfirmou ter conhecimento no Math educator 1.2 e /ou outros softwares não mencionados na pesquisa.

Na figura 2 possibilitou-se identificar que nem todo docente encontra-se totalmente conectado as tecnologias disponíveis, verificando-se que este fato pode estar atrelado também à faixa etária de professores pesquisados.

Figura 2. Percentual de faixa etária de docentes que utilizam algum software na prática pedagógica

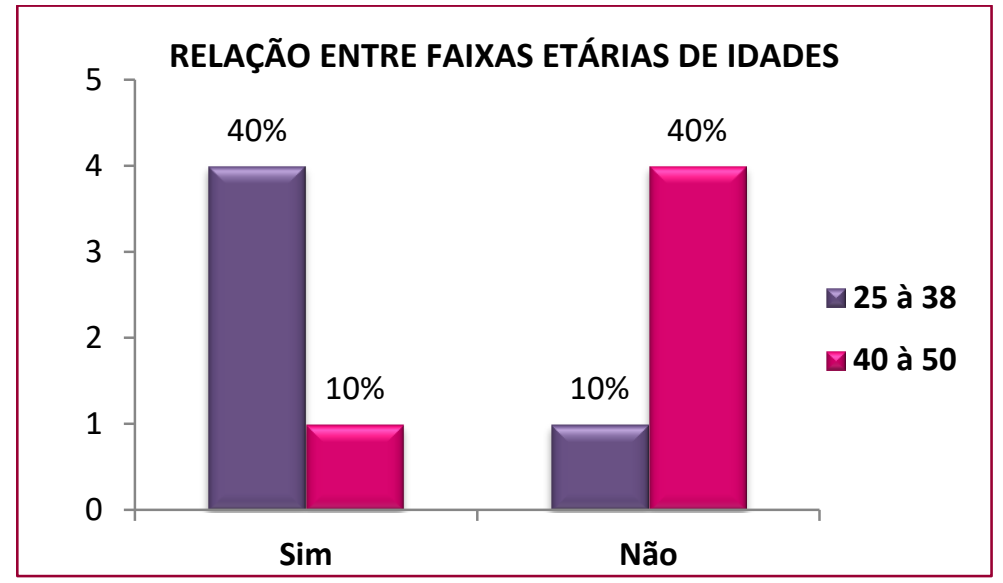


A análise de dados, em relação ao questinário aplicado contemplou na Tabela 1, a avaliação dos professores quanto ao grau de dificuldades no manuseio dos softwares matemáticos, que resultou no seguinte: nas questões relativas à Falta de incentivo (políticas públicas) e precariedades das condições prediais e insuficiência de computadores, destacam-se os maiores graus de dificuldades, com uma hegemonia de concordância de oito pessoas, cada. Entretanto, para o parâmetro estudado (Menor), foi obtido apenas um voto, que se deu de forma semelhante para as questões de falta de conhecimento e qualificação por parte dos professores, bem como, falta de incentivo por parte das políticas públicas que, anteriormente ganhou o maior número de votos enquanto avaliados no parâmetro (Maior).

Tabela 1. Avaliação dos professores quanto ao grau de dificuldades no manuseio dos softwares matemáticos.

\begin{tabular}{|c|c|c|c|}
\hline \multirow{2}{*}{$\begin{array}{c}\text { Numa escala de } 1 \text { a } 5 \text {, sendo } 1 \text { para a maior dificuldade e } 5 \text { para a } \\
\text { menor dificuldade encontrada, avalie com relação a esses graus o } \\
\text { manuseio dos softwares matemáticos? }\end{array}$} & \multicolumn{3}{|c|}{ Dificuldade } \\
\hline & Maior & Menor & Razoável \\
\hline \multicolumn{4}{|l|}{ Atribuições } \\
\hline Falta de conhecimento e qualificação por parte dos professores & 4 & 1 & 5 \\
\hline $\begin{array}{l}\text { Falta de incentivo (políticas públicas) que possibilitem uma } \\
\text { formação continuada à área específica de cada professor }\end{array}$ & 8 & 1 & 1 \\
\hline $\begin{array}{l}\text { Estabelecer a escolha do melhor software que se adeque ao } \\
\text { conteúdo estudado }\end{array}$ & 3 & 4 & 3 \\
\hline Falta de motivação para a utilização dos softwares & 4 & 3 & 3 \\
\hline $\begin{array}{l}\text { Precariedade das condições prediais (tamanho e condições físicas) } \\
\text { e insuficiente quantidade de computadores que atenda a demanda } \\
\text { dos alunos. }\end{array}$ & 8 & 2 & - \\
\hline
\end{tabular}

Segundo Salvan (2004), toda prática de ensino contém uma teoria de aprendizagem predominante, explicitada de forma consciente ou inconsciente pelo professor. Contudo, nenhuma teoria sozinha explica como acontece o processo de aprendizagem. Pretto (1996) admite, que as novas tecnologias podem representar uma nova forma de pensar e sentir ainda em construção, vislumbrando, assim, um papel importante para elas na elaboração do pensamento.

\section{CONSIDERAÇÕES FINAIS}

A pesquisa realizada demonstrou que o número de pessoas que têm acesso a computadores, internet ou mesmo recursos digitais (softwares), tem aumentado significativamente. No entanto, torna-se imprescindível que educadores como um todo (jovens e mais velhos) tenham uma formação pedagógica no qual as mídias sejam aplicadas e discutidas nesta perspectiva, uma vez que elas também estão a serviço da educação.

Com relação aos graus de dificuldades sugeridos no manuseio dos softwares matemáticos, as opiniões foram quase que unânimes com relação à falta de incentivo (políticas públicas) que possibilitem uma formação continuada à área específica de cada professor e precariedade das condições prediais (tamanho e condições físicas) e insuficiente quantidade de computadores que atenda a demanda dos alunos, percebendo assim que esses dois itens foram considerados como sendo as maiores barreiras impostas ao dinamismo e progresso das práticas pedagógicas. 


\section{REFERÊNCIAS}

[1] BERNART, A. M. Mídias digitais: um diferencial no ensino e aprendizagem de matemática. 2010. Disponível em: <http://www.lume.ufrgs.br/bitstream/handle/10183/31595/000782509.pdf?...1> . Acesso em 20 jan. 2014

[2] <http://repositorium.sdum.uminho.pt/bitstream/1822/9996/1/SCAN0002.pdf.> Acesso em: 20 jan. 2014.

[3] CYSNEIROS, P. G. "A gestão da Informática na Escola Pública”. In: XI. Simpósio Brasileiro de Informática na Educação. Maceió - AL. Anais... SBIE 2000.

[4] DULliUS, M. M.; HAETINGER, C. Ensino e aprendizagem de matemática em ambientes informatizados: concepção, desenvolvimento, uso e integração destes no sistema educacional. 2005. Disponível em: < http://www.pucrs.br/famat/viali/tic literatura/artigos/tics/Dulius Haetinger.pdf >. Acesso em 20 jan.2014.

[5] IÉGAS, A.L.F.; LUPPI, M. R. A formação do Professor Frente às Novas Tecnologias. Disponível em:

[6] <http://www.uel.br/pessoal/berbel/metodologia_da_problematiza\%E7\%E3o/docs/3-

[7] 01082K2.doc> Acesso em: 20 jan. 2007.

[8] ISOTANI, S.; SAHARA, R. H.; BRANDÃO, L. O. 2001. iMática: Ambiente Interativo de Apoio ao Ensino de Matemática via internet. São Paulo, Instituto de Matemática e Estatística - Universidade de São Paulo (USP).

[9] LORENZATO, S. Para aprender matemática. Campinas/SP: Autores Associados, 2006.

[10] LOURENÇO, A.; PAIVA, M.O.A de. A motivação escolar e o processo de aprendizagem. Revista Ciências \& Cognição, v.15, n.2, p.132-141, 2010.

[11] MERCADO, L.P.L. Novas tecnologias na educação: reflexão sobre a prática. Maceió: EDUFAL, 210p. 2002.

[12] PRETTO, N. 1996. Uma escola sem/com futuro - educação e multimídia. Campinas: Papirus.

[13] SALVAN, A. F. M. Avaliando as dificuldades da aprendizagem em matemática. 2004. 61f. Especialização. (Trabalho de Monografia em Educação da Matemática) - Universidade do Extremo Sul Catarinense, UNESC.

[14] SANTANA, J. C. de; MEDEIROS, Q. A Utilização do uso de novas tecnologias no ensino de ciências. Disponível em <http://www.senept.cefetmg.br/galerias/Arquivos_senept/anais/terca_tema1/TerxaTema1Artigo14.pdf.>. Acesso em 25 de ago. 2014

[15] TEDESCO. J.C. Introdução. In: TEDESCO, J.C. (Org.). Educação e novas tecnologias: esperança ou incertezas. São Paulo: Cortez; Buenos Ayres: Instituto Internacional de Planeamiento de la Educación; Brasília: UNESCO, 2004.

[16] ZULATTO, R. B. A. Professores de matemática que utilizam softwares de geometria dinâmica: suas características e perspectivas. 2002. 184f. Dissertação (Mestrado em Educação Matemática) - Universidade Estadual Paulista, Campos de Rio Claro, SP. 


\section{Capítulo 17}

Gincana de matemática: Uso de kits educacionais conforme habilidades da Base Nacional Comum Curricular (BNCC)

\section{Jerônimo Freire Silva}

Resumo: 0 Ensino Fundamental, com nove anos de duração, é a etapa mais longa da Educação Básica no Brasil, atendendo estudantes entre 6 e 14 anos. A problemática em que se insere esta pesquisa está relacionada aos baixos rendimentos do IDEB em matemática de 11 escolas dos anos finais do ensino fundamental da cidade do Natal/RN (G11). Com o objetivo de motivar os seus principais atores (professores de matemática e estudantes), foi realizada uma Gincana de Matemática na Escola Municipal Francisca Ferreira com uso de Kits Educacionais com ênfase nas unidades temáticas: Álgebra, geometria, grandezas e medidas. Esta pesquisa teve como objetivo investigar a utilização de diferentes estratégias (jogos matemáticos e resolução de problemas), na elaboração dos problemas/desafios com base nas habilidades do $6^{\circ}$ ao $9^{\circ}$ ano da Base Nacional Comum Curricular (BNCC), conforme critérios de construção dos desafios, segundo Pólya e a importância do conhecimento prévio proposto por Ausubel. 0 processo metodológico, deu início com uma oficina de 8 horas na capacitação dos professores convidados do G11, para o uso dos Kits Educacionais, organização da Gincana e principalmente na elaboração dos problemas/desafios. Após a Gincana foram analisados os questionários online aplicados com os participantes, constatou-se a forma prazerosa pelo uso dos Kits (inovadora e contextualizada) e o aumento da motivação dos estudantes na discussão dos assuntos abordados. Conclui-se que a experiência foi exitosa para professores e estudantes, devendo a mesma se repetir nas demais escolas do G11, esperando com isso nas próximas avaliações do IDEB melhores resultados.

Palavras-chave: Gincana, Matemática, estratégias, recursos educacionais, BNCC. 


\section{INTRODUÇÃO}

Durante todo o processo de escolarização no Brasil, mais especificamente no ensino fundamental, os estudantes se encontram imersos em cenários educacionais que colaboram ou não com o seu aprendizado, isso dependendo das estratégias de aprendizagens, dos recursos educacionais e principalmente da qualidade docente. Nas últimas décadas avanços foram realizados para diagnosticar a qualidade do ensino nas escolas, periodicamente as instituições de ensino são avaliadas, dentre os quais podemos destacar o IDEB. Nos últimos exames se constata que, 8 de cada 10 alunos concluintes do ensino fundamental não aprenderam o adequado em Matemática. A meta estabelecida para o ano de 2022 é que o IDEB das escolas seja 6,0, média que corresponde a um sistema de educação de qualidade, comparado aos dos países desenvolvidos.

Recentemente o MEC oficializou a Base Nacional Comum Curricular (BNCC). É um documento de caráter normativo que define o conjunto orgânico e progressivo de aprendizagens essenciais que todos os alunos devem desenvolver ao longo das etapas e modalidades da Educação Básica, de modo a que tenham assegurados seus direitos de aprendizagem e desenvolvimento, em conformidade com o que preceitua o Plano Nacional de Educação (PNE). Este importante documento, somado aos recursos didáticos (Kits Educacionais), será de grande valia para apresentar estratégias de aprendizagem no ensino da matemática básica conforme proposta da elaboração dos problemas para Gincana em estudo.

A matemática sempre esteve presente em nosso meio, desde os tempos mais remotos da história da humanidade e mais ainda na contemporaneidade com os avanços tecnológicos e científicos, se consolidando como uma das disciplinas mais necessárias e presentes no currículo escolar, pois desenvolve papel importante no aprendizado dos estudantes, desde que seja trabalhada corretamente, respeitando o processo de desenvolvimento dos alunos.

As preocupações quanto as deficiências no ensino e aprendizagem da matemática é visto na literatura tanto a nível nacional como internacional, trabalhos como os de Dienes (1973), Kline (1976) e pesquisas como as de Schliemann (1991) e D`Ambrósio (1996), e outros tem colaborado para documentar os avanços e os obstáculos nas práticas pedagógicas.

Com o objetivo de melhorar os dados do IDEB de 11 escolas municipais da cidade do Natal/RN (G11), foi realizada uma oficina com os professores de matemática, com o propósito de atualizar estratégias de aprendizagem com uso de kits Educacionais (unidades temáticas: Álgebra, geometria, grandezas e medidas). Os professores são capacitados para elaborar problemas / desafios embasados nas habilidades do $6^{\circ}$ ao $9^{\circ}$ ano da Base Nacional Comum Curricular (BNCC), conforme critérios de construção dos problemas/desafios, segundo Pólya (1945) e a importância do conhecimento prévio proposto por Ausubel (1968). Uma das escolas do G11, a escola municipal Francisca Ferreira foi escolhida para ser a sede da GINCANA de Matemática.

o Centro Universitário Mauricio de Nassau, através da disciplina Metodologia do Ensino da Matemática, estudantes do curso de Pedagogia analisam o uso de jogos e resolução de problemas como um recurso facilitador no processo de ensino e aprendizagem da matemática na Educação Infantil e nos anos iniciais do Ensino Fundamental.

Do ponto de vista da matemática, a palavra "problema" tem conotação diferente do senso comum, pois a mesma é entendida como algo que pode trazer consequências desagradáveis. De uma forma geral, as pessoas tendem a evitar problemas. No caso da matemática, é a garantia de horas dedicada a encontrar a resposta para o desafio proposto, todo esse esforço pode vir acompanhado de prazer e ser algo apaixonante. A resolução de problemas e desafios é a habilidade mais útil que um aluno pode experimentar em uma disciplina de matemática. Cabe ao professor a maestria de conduzir a sua prática pedagógica, motivando as técnicas de resolução com uso das ferramentas matemáticas (conteúdos), para que o aluno possa raciocinar, ordenar e classificar informações, prever e testar hipóteses, e avaliar as soluções. Quando isso é colocado no sentido competitivo de uma gincana é importante também saber trabalhar em equipe, pois além das habilidades intelectuais os estudantes experimentam o autocontrole emocional.

\section{METODOLOGIA}

O processo metodológico deste trabalho de pesquisa teve início com uma oficina de capacitação dos docentes, com o intuito de prepara-los para organizar e administrar uma GINCANA de matemática com uso de Kits Educacionais específicos para os conteúdos de matemática a serem abordados no evento. Após 
a capacitação foi realizada uma Gincana de matemática na escola municipal Francisca Ferreira, do grupo G11, com IDEB abaixo das metas estabelecidas pela Secretaria Municipal de Educação. Como instrumentos de avaliação foram realizadas entrevistas com os estudantes e aplicado um questionário sobre as atividades da Oficina com os professores convidados do G11.

Participantes, Procedimentos e Instrumentos.

Em 09/11/2017 foi realizada a Oficina “Gincana de Matemática” no Centro de Capacitação de Professores, CEMURE, com a participação de 13 professores de matemática do G11, com carga horaria de 8 horas, distribuída em dois dias. Nesta ocasião foram ministrados os assuntos: 0 Ensino de Matemática no Brasil (Dicotomia entre teoria e prática); A importância da Ludicidade no Ensino da Matemática; A aprendizagem por Projetos - Como organizar e executar uma GINCANA de Matemática?; Como administrar a gincana motivando; A mesa avaliadora dos trabalhos - Quais os critérios?; A premiação. Certificação CIDEPE "QUALIDADE DE ENSINO"; Como construir os Desafios e o uso dos recursos didáticos (Kits) conforme as habilidades do BNCC; Conhecendo o Painel Demonstrativos EQ319 - Destinado ao estudo de razões, proporções e triângulos semelhantes; Conhecendo o Painel Demonstrativos EQ327 Destinado ao estudo de proporção inversa e equação do primeiro Grau e Inequações; Conhecendo o Painel Demonstrativos EQ377D - Destinado ao estudo da Geometria (polígonos, perímetro e área); O Uso das TICs no Ensino da Matemática e Construindo o registro da Gincana nas Redes Sociais. Ao final das atividades da oficina, foram selecionados 5 problemas / Desafios para ser trabalhados na GINCANA de Matemática.

No dia 20/11/2017 na Escola Municipal Professora Francisca Ferreira da Silva, localizada na Avenida Industrial João Francisco da Motta, no 3804, Bairro Bom Pastor, Zona Oeste de Natal, Estado do Rio Grande do Norte foi realizada a Gincana, no turno vespertino com a participação das turmas do Ensino Fundamental com a participação de 4 grupos, identificados por cores das camisetas (branco, preto, vermelho e azul) formados por um aluno do 6 ao 9 ano, totalizando 4 estudantes por grupo. 0 local da realização da GINCANA foi no pátio da escola, uma área retangular de aproximadamente 600 metros quadrados, onde foi instalada a mesa avaliadora dos trabalhos com a participação dos professores (8) e com o cerimonial sob responsabilidade dos professores de matemática da Escola Municipal Professora Francisca Ferreira (Jerônimo Freire, Angélica M R de Lima Oliveira e Alberto de Souza e Silva). O layout do espaço físico da Gincana, com a distribuição dos participantes e instrumentos necessários a qualidade do evento. Em cada vértice do pátio foi colocado uma mesa e 4 cadeiras para os componentes dos respectivos grupos do 6 ao 9 ano, com suas torcidas. A Gincana é dividida em 3 etapas, a primeira consta de ações a serem realizadas pelo grupo com a participação da sua respectiva torcida com o intuito de criar um clima solidário e ético entre os participantes, na segunda etapa são apresentados jogos matemáticos (raciocínio logico) a serem realizados entre os grupos e por último, a etapa 3 direcionada aos problemas / desafios com o uso dos Kits Educacionais.

\section{RESULTADOS E DISCUSSÃO.}

Da oficina de capacitação dos professores foi elaborado um quadro referente ao KIT educacional selecionado para trabalhar os conteúdos de matemática conforme as unidades temáticas referentes a cada ano do ensino fundamental do BNCC.

Cada habilidade (conforme área temática e objeto do conhecimento) apresentada nos quadros (1,2 e 3) está sinalizando um problema para cada ano do ensino fundamental. Os professores após o entendimento do uso dos Kits e dos critérios de construção dos problemas trabalhados na Oficina estão aptos a propor os desafios (construir). 
Quadro 1 - EQ327 - Estudo de proporção inversa e equação do primeiro Grau e Inequações.

\begin{tabular}{|c|c|c|}
\hline $\begin{array}{l}\text { Unidades } \\
\text { temáticas }\end{array}$ & $\begin{array}{c}\text { Objetos de } \\
\text { conhecimento }\end{array}$ & Habilidades \\
\hline \multirow{4}{*}{ Álgebra } & $\begin{array}{l}\text { Propriedades } \\
\text { igualdade }\end{array}$ & $\begin{array}{l}\text { (EF06MA14). Reconhecer que a relação de igualdade } \\
\text { matemática não se altera ao adicionar, subtrair, multiplicar ou } \\
\text { dividir os seus dois membros por um mesmo número e utilizar } \\
\text { essa noção para determinar valores desconhecidos na resolução } \\
\text { de problemas. }\end{array}$ \\
\hline & $\begin{array}{l}\text { Equações polinomiais } \\
\text { do } 1^{\text {o }} \text { grau }\end{array}$ & $\begin{array}{l}\text { (EF07MA18). Resolver e elaborar problemas que possam ser } \\
\text { representados por equações polinomiais de } 1^{\text {o }} \text { grau, redutíveis à } \\
\text { forma } a x+b=c \text {, fazendo uso das propriedades da igualdade. }\end{array}$ \\
\hline & $\begin{array}{l}\text { Variação } \\
\text { grandezas: } \\
\text { diretamente } \\
\text { proporcionais, } \\
\text { inversamente } \\
\text { proporcionais ou não } \\
\text { proporcionais }\end{array}$ & $\begin{array}{l}\text { (EF08MA12). Identificar a natureza da variação de duas } \\
\text { grandezas, diretamente, inversamente proporcionais ou não } \\
\text { proporcionais, expressando a relação existente por meio de } \\
\text { sentença algébrica e representá-la no plano cartesiano. } \\
\text { (EF08MA13) Resolver e elaborar problemas que envolvam } \\
\text { grandezas diretamente ou inversamente proporcionais, por } \\
\text { meio de estratégias variadas. }\end{array}$ \\
\hline & $\begin{array}{l}\text { Grandezas } \\
\text { diretamente } \\
\text { proporcionais } \\
\text { grandezas } \\
\text { inversamente } \\
\text { proporcionais }\end{array}$ & $\begin{array}{l}\text { (EF09MA08) Resolver e elaborar problemas que envolvam } \\
\text { relações de proporcionalidade direta e inversa entre duas ou } \\
\text { mais grandezas, inclusive escalas, divisão em partes } \\
\text { proporcionais e taxa de variação, em contextos socioculturais, } \\
\text { ambientais e de outras áreas. }\end{array}$ \\
\hline
\end{tabular}

Quadro 2 - EQ377 - Estudo da Geometria (razão e proporção, triângulos semelhantes).

\begin{tabular}{|c|c|c|}
\hline Unidades & Objetos de conhecimento & Habilidades \\
\hline \multirow[t]{2}{*}{ Geometria } & $\begin{array}{l}\text { Construção de figuras semelhantes: } \\
\text { ampliação e redução de figuras planas em } \\
\text { malhas quadriculadas }\end{array}$ & $\begin{array}{l}\text { (EF06MA20) Identificar características dos } \\
\text { quadriláteros, classificá-los em relação a } \\
\text { lados e a ângulos e reconhecer a inclusão e a } \\
\text { intersecção de classes entre eles. } \\
\text { (EF06MA21) Construir figuras planas } \\
\text { semelhantes em situações de ampliação e } \\
\text { de redução, com o uso de malhas } \\
\text { quadriculadas, plano cartesiano ou } \\
\text { tecnologias digitais. }\end{array}$ \\
\hline & $\begin{array}{l}\text { Construção de retas paralelas e } \\
\text { perpendiculares, fazendo uso de réguas, } \\
\text { esquadros e softwares }\end{array}$ & $\begin{array}{l}\text { (EF06MA22) Utilizar instrumentos, como } \\
\text { réguas e esquadros, ou softwares para } \\
\text { representações de retas paralelas e } \\
\text { perpendiculares e construção de } \\
\text { quadriláteros, entre outros. }\end{array}$ \\
\hline
\end{tabular}


Quadro 3 - EQ377D - Destinado ao estudo das medidas (polígonos, perímetro e área).

\begin{tabular}{|c|c|c|}
\hline $\begin{array}{l}\text { Unidades } \\
\text { temáticas }\end{array}$ & Objetos de conhecimento & Habilidades \\
\hline \multirow[t]{2}{*}{$\begin{array}{l}\text { Grandezas e } \\
\text { medidas }\end{array}$} & $\begin{array}{l}\text { Problemas sobre medidas envolvendo } \\
\text { grandezas como comprimento, massa, } \\
\text { tempo, temperatura, área, capacidade e } \\
\text { volume }\end{array}$ & $\begin{array}{l}\text { (EF06MA24) Resolver e elaborar problemas } \\
\text { que envolvam as grandezas comprimento, } \\
\text { massa, tempo, temperatura, área (triângulos } \\
\text { e retângulos), capacidade e volume (sólidos } \\
\text { formados por blocos retangulares), sem uso } \\
\text { de fórmulas, inseridos, sempre que possível, } \\
\text { em contextos oriundos de situações reais } \\
\text { e/ou relacionadas às outras áreas do } \\
\text { conhecimento. }\end{array}$ \\
\hline & $\begin{array}{l}\text { Perímetro de um quadrado como } \\
\text { grandeza proporcional à medida do lado }\end{array}$ & $\begin{array}{l}\text { (EF06MA29) Analisar e descrever } \\
\text { mudanças que ocorrem no perímetro e na } \\
\text { área de um quadrado ao se ampliarem ou } \\
\text { reduzirem, igualmente, as medidas de seus } \\
\text { lados, para compreender que o perímetro é } \\
\text { proporcional à medida do lado, o que não } \\
\text { ocorre com a área. }\end{array}$ \\
\hline
\end{tabular}

Figura 1 - Imagem da Gincana do Grupo Branco.

A figura 1 ao lado apresenta a discussão do Grupo
Branco para achar a solução do problema da etapa 3,
relacionado ao uso do EQ327 - Estudo de proporção
inversa e equação do primeiro Grau e Inequações.
Este problema envolve a habilidade (EF06MA14).
Reconhecer que a relação de igualdade matemática
não se altera ao adicionar, subtrair, multiplicar ou
dividir os seus dois membros por um mesmo
número e utilizar essa noção para determinar
valores desconhecidos na resolução de problemas.
Proposta para um conteúdo do $6^{\circ}$ ano conforme
podemos observar no código alfanumérico citado.
Esta atividade é proposta para uma ampla discussão
do grupo, em definir uma estratégia para solução do
problema. Em nossas entrevistas junto aos grupos
sondamos aspectos do conhecimento do conteúdo

Das habilidades selecionadas conforme tratadas no Quadro 3, o objeto de conhecimento é certas situações ministrado pelo professor com uso de recursos didáticos (esquadros, relógio, balança, réguas, trenas, etc). $\mathrm{Na}$ literatura muitas vezes, termos como "recurso didático", "material didático", "recurso educativo", "material concreto" e "material manipulável" são usados pelos professores para descrever os instrumentos utilizados como facilitadores da aprendizagem. Os kits Educacionais apresentam uma inovação nos recursos que a escola pode e deve colocar à disposição do professor de matemática. Estas práticas com uso dos Kits são fundamentais para a compreensão dos assuntos da matemática aplicada e pura, e colabora com o desenvolvimento do raciocínio lógico e crítico, estimula a investigação e pode ser prazeroso (fruição). Na figura 1, é visível o interesse do grupo de estudantes na manipulação e troca de ideias para apresentar uma solução ao desafio proposto. É fato que estratégias de aprendizagem que possam contribuir com a forma cooperativa de trabalho, respeito a forma de pensar dos componentes e 
oponentes em situação de jogos e desafios, são importantes para o cenário de uma educação de qualidade que possa revelar uma motivação maior para aprender matemática.

Figura 2 - EQ376, um equipamento inovador com tábuas individuais onde o aluno pode praticar e interagir com os exercícios aplicados no painel pelo professor.

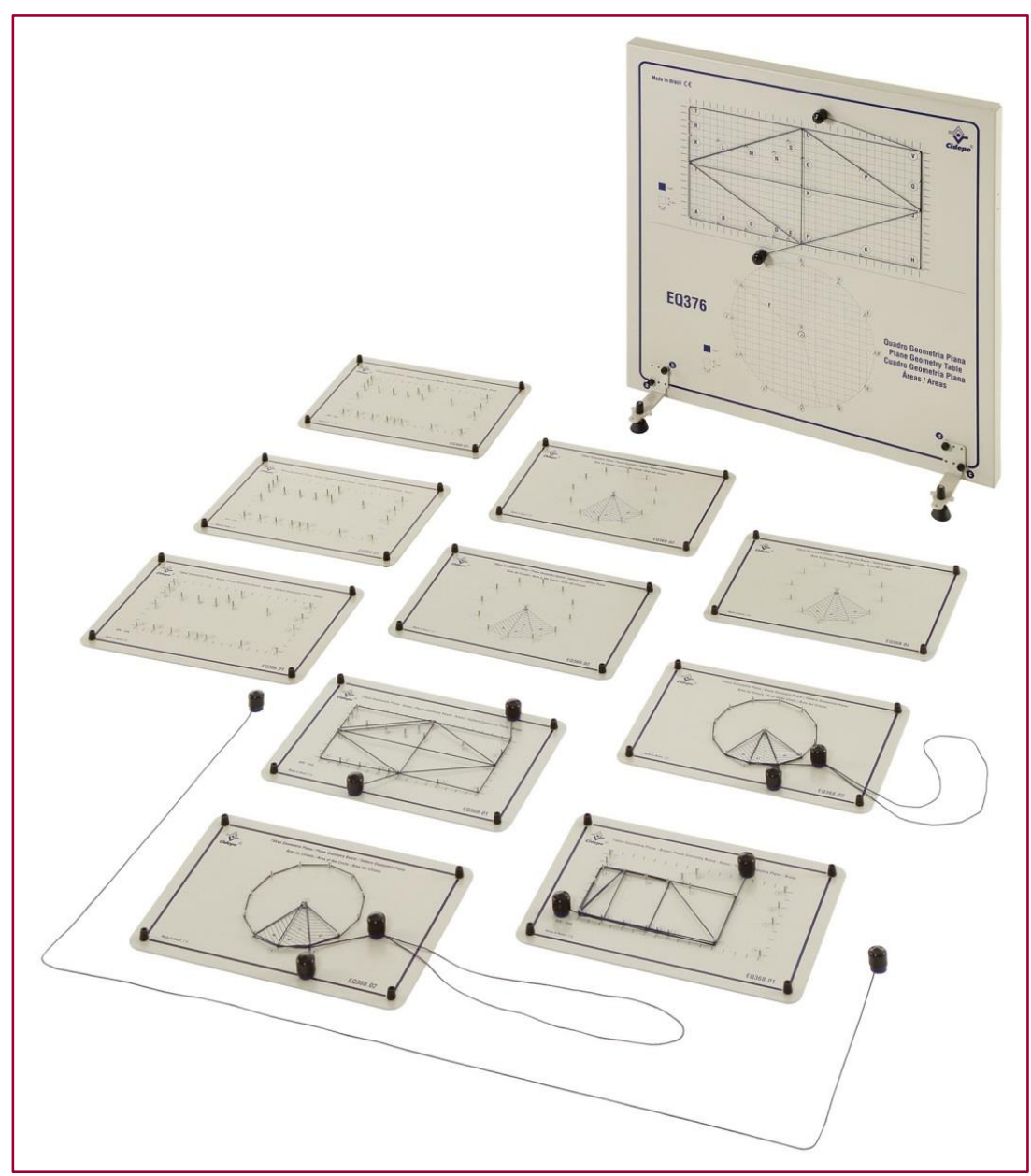

O uso desse Kit Educacional permite estudar o domínio da Matemática que ocorre por meio das chamadas construções geométricas, que podem ser vistas como maneiras de expressar graficamente a forma de determinados entes geométricos, ou seja, representações dos mesmos. Subentende-se, assim, à realização de construções desta natureza, o conhecimento das propriedades e definições matemáticas do objeto em questão. Esta prática educativa pode ser utilizada em sala de aula para abordagem dos assuntos da geometria plana, as tabuas individuais são utilizadas pelos grupos de estudantes conforme demonstração do assunto ou problema formulado pelo professor no painel demonstrativo (vertical).

É fundamental a construção de estratégias para solução de problemas. Os desafios propostos pelas habilidades do Quadro 2, exemplifica a existência de uma aprendizagem significativa, e aponta a existência de conhecimentos prévios que sirvam de ancoradouro para o novo conhecimento no dizer de Ausubel (1968). A construção da situação-problema considerou como premissa os conceitos de geometria plana que os estudantes já detinham em sua estrutura cognitiva.

O questionário abaixo foi aplicado com os professores após Oficina, foi utilizado um formulário do Google e enviado online para o professor (seu e-mail e para o seu WhatsApp). Após o preenchimento foi gerado vários gráficos dos questionamentos propostos, mas em razão da limitação de páginas para a publicação do artigo e do tamanho solicitado 2MB (Mega Bytes), optamos pelo quadro de resposta abaixo em percentuais. 
Quadro 4 - Questionário de avaliação da oficina

\begin{tabular}{|c|c|c|c|}
\hline \multirow{2}{*}{$\begin{array}{l}\text { Questionário Online aplicado com os participantes da Oficina } \\
\text { Perguntas }\end{array}$} & \multicolumn{3}{|c|}{ Respostas (\%) } \\
\hline & Não & Sim & Em parte \\
\hline $\begin{array}{l}\text { Questão } 1 \text { - Você pretende introduzir em sua prática pedagógica a } \\
\text { GINCANA de matemática na sua escola? }\end{array}$ & - & 80 & 20 \\
\hline $\begin{array}{l}\text { Questão } 2 \text { - Na sua opinião a falta de material educativo na escola é } \\
\text { um obstáculo para a organização dessa atividade pedagógica (Gincana } \\
\text { e aulas práticas com uso dos Kits Educacionais)? }\end{array}$ & - & 90 & 10 \\
\hline $\begin{array}{l}\text { Questão } 3 \text { - No seu julgamento o entendimento do desafio / problema } \\
\text { em uma Gincana de Matemática é importante para executar um plano } \\
\text { estratégico para solucionar o problema? }\end{array}$ & - & 90 & 10 \\
\hline $\begin{array}{l}\text { Questão } 4 \text { - O recurso educacional "KIT de matemática" ajuda na } \\
\text { elaboração de um problema / desafio? }\end{array}$ & 10 & 80 & 10 \\
\hline $\begin{array}{l}\text { Questão } 5 \text { - A identificação do conteúdo de matemática, ou seja, o } \\
\text { conhecimento do assunto da matemática poderia ser útil na resolução } \\
\text { do problema (ajuda na estratégia)? }\end{array}$ & - & 80 & 20 \\
\hline $\begin{array}{l}\text { Questão } 6 \text { - Você concorda que um bom problema / desafio ao ser } \\
\text { elaborado deve fortalecer o entendimento dos conteúdos de } \\
\text { matemática, ao ser aplicado para soluciona-lo e que o mesmo seja } \\
\text { adequado a capacidade do estudante, desafiando-o e, oferecendo uma } \\
\text { chance justa de resolver em um tempo razoável? }\end{array}$ & - & 80 & 20 \\
\hline $\begin{array}{l}\text { Questão } 7 \text { - Você concorda com a nossa proposta de elaboração do } \\
\text { desafio / problema está atrelada ao BNCC (área temática, objetos de } \\
\text { conhecimento e habilidades)? }\end{array}$ & 10 & 80 & 10 \\
\hline
\end{tabular}

Questionário Online aplicado com os participantes da Oficina Perguntas
Respostas (\%) Elevado Médio

Questão 8 - Qual seu nível de conhecimento do planejamento e execução de uma Gincana de Matemática antes da Oficina?

\begin{tabular}{|l|c|c|c|c|}
\hline $\begin{array}{l}\text { Questionário Online aplicado com os participantes da } \\
\text { Oficina } \\
\text { Perguntas }\end{array}$ & Excelente & Bom & Razoável & $\begin{array}{c}\text { Precisa } \\
\text { melhorar }\end{array}$ \\
\hline $\begin{array}{l}\text { Questão 9 - Qual a sua opinião sobre o desempenho do } \\
\text { professor (domínio de conteúdo, didática e material } \\
\text { usado como suporte)? }\end{array}$ & 70 & 30 & - & - \\
\hline Questão 10 - Qual a sua avaliação da OFICINA? & 100 & - & - & - \\
\hline
\end{tabular}

A matemática é um modo sistemático de estruturar o pensamento e os argumentos, que é estreitamente amarrado para um corpo coerente de conhecimento associado. A prática matemática preocupa-se em encontrar soluções para problemas, sejam relacionados a problemas práticos (aplicados) ou internos, a matemática (pura). A questão 10 acima revela o interesse demonstrado pelos professores em dinamizar as suas práticas pedagógicas, e a oficina conforme podemos destacar teve $100 \%$ de aprovação. Outro ponto importante é na inovação dos recursos pedagógicos, os Kits educacionais atenderam perfeitamente aos anseios dos professores quando os mesmos tiveram que elaborar seus problemas segundo as habilidades do BNCC, conforme atesta as questões 2 e 4.

As respostas dos estudantes aos questionamentos feitos por ocasião da Gincana somados as respostas do Questionário aplicado aos professores de matemática, participantes da oficina, transmite uma certeza de que as estratégias utilizadas para resolver os desafios foram satisfatórias, proporcionando uma alta motivação para ampliar as discussões em sala de aula.

Durante a oficina os professores são motivados a conhecer vários sites que apresentam informações relacionadas aos problemas matemáticos, conforme a faixa etária, estratégias e soluções de problemas típicos abordados em olimpíadas nacionais e internacionais de matemática. Destacamos o NRICH enriching mathematics - www.nrich.maths.org.uk 
Compreende-se que os professores são conscientes de suas necessidades formativas de matemática ao apontarem na questão 4, a importância do uso dos Kits educacionais nas aulas tradicionalmente ministradas apenas com o uso da lousa. Ao mesmo tempo, os estudantes extravasam a necessidade de aulas mais dinâmicas, pois destacam, a importância dos recursos didáticos utilizados em sala. A proposta de elaboração dos problemas com base nas habilidades apresentadas no BNCC, abre a possibilidade em momento futuro uma outra pesquisa que possa avaliar quantitativamente a distribuição dos problemas com base nas unidades temáticas.

\section{CONCLUSÕES}

Os objetivos propostos no início do trabalho foram alcançados, percebemos nos professores e estudantes um entusiasmo contagiante para o processo ensino aprendizagem da matemática nas 11 escolas em que o índice do IDEB encontra-se abaixo das metas traçadas pela secretaria municipal de Educação. Neste sentido, concluímos que a experiência foi exitosa, e a proposta da Gincana foi solicitada por todos os participantes para repetir nas demais escolas do G11. Os resultados confirmam o interesse dos professores em utilizar nas suas práticas educativas os recursos educacionais (Kits), bem como o conhecimento na elaboração dos problemas conforme critérios quantificáveis e adequados a capacidade dos estudantes, levando em consideração aos conhecimentos prévios.

\section{REFERÊNCIAS}

[1] AUSUBEL, D. P. (1968). Psicologia Educacional: Uma Visão Cognitiva. Holt, Rinehart e Winston.

[2] D'AMBROSIO, Beatriz S. Como ensinar matemática hoje? Temas e Debates. SBEM. Ano II. N2. Brasilia. 1989. P. 15-19

[3] DIENES, Zoltan P. O poder da matemática. São Paulo: EPU, 1973.

[4] KLINE, Moris. O fracasso da matemática moderna. São Paulo:IBRASA, 1976.

[5] PÓLYA, G. (1962). Descoberta Matemática: Na compreensão, aprendendo e ensinando a resolução de problemas.

[6] SCHLIEMANN, A.D; Na vida dez, na escola zero. São Paulo; Cortez, 1988.

[7] BRASIL. MINISTÉRIO DA EDUCAÇÃO. SECRETARIA DE EDUCAÇÃO BÁSICA. Texto da BNCC, 2016. Disponível em: <http://basenacionalcomum.mec.gov.br>. Acesso em: 25 abr. 2017. 


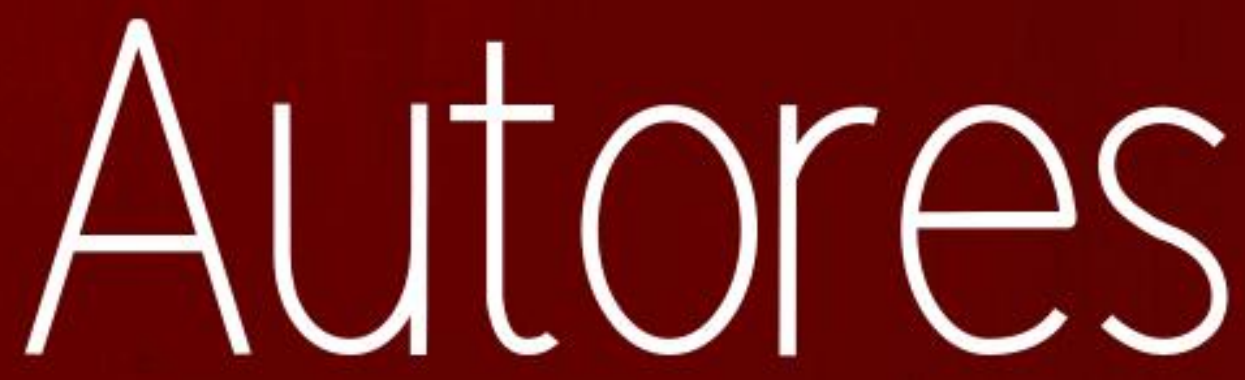




\section{ALINE CLARO DE FREITAS ABUCARMA}

Possui graduação em Licenciatura em Matemática pela Universidade Estadual Paulista Júlio de Mesquita Filho (2005), Pós-graduação em Novas Tecnologias no Ensino da Matemática pela Universidade Federal Fluminense (2011) e Mestrado Profissional em Matemática pela Universidade Estadual Paulista Júlio de Mesquita Filho (2016). Atualmente é Professora de Educação Básica no Ensino Público do Estado de São Paulo e está designada como Professora Coordenadora de Área no Programa Ensino Integral na Escola Professor Oracy Matricardi em Presidente Prudente.

\section{ANA CRISTIANE DE SOUSA}

Especialista em Fundamentos da educação: práticas pedagógicas (2015), graduanda em Licenciatura em Matemática pela Universidade Estadual da Paraíba (2007). Atualmente é professora efetiva do Estado da Paraíba e da Prefeitura Munic. de São Sebastião de Lagoa de Roça

\section{ANGÉLICA DA FONTOURA GARCIA SILVA}

Possui graduação em licenciatura em Ciências habilitação em Matemática, doutora em Educação Matemática pelo Programa de Estudos Pós-graduados em Educação Matemática da PUC-SP, mestre em Educação pelo Programa Educação: História Política e Sociedade da PUC-SP . Fez estágio de doutoramento Sandwich em 2006, na Escola Superior de Educação de Lisboa sob a supervisão da professora Maria de Lurdes Serrazina. É professora contratada pelo Programa de Pós-graduação em Educação Matemática da Universidade Anhanguera de São Paulo. Desenvolve atividade de pesquisa sobre o Formação de Professores que ensinam Matemática. Participa do grupo de pesquisa: Observatório da Educação.

\section{BARBARA CRISTINA MATHIAS DOS SANTOS}

Possui graduação em Ciências Contábeis pelo Centro Universitário Augusto Motta (2002), especialização em ORIENTAÇÃO EDUCACIONAL E PEDAGÓGICA pelo INSTITUTO A VEZ DO MESTRE(2011) e especialização em PSICOPEDAGOGIA pelo INSTITUTO A VEZ DO MESTRE(2010). Mestrado Profissional no Ensino das Ciências da Educação Básica pela UNIGRANRIO (2016). Atualmente é Professora da Secretaria municipal de Educação de Duque de Caixas. Tem experiência na área de Educação. Atuando principalmente nos seguintes temas: Educação Financeira, EDUCAÇÃO MATEMATICA, Matemática inclusiva, ENSINO FUNDAMENTAL.

\section{BRUNA ALBIERI CRUZ DA SILVA}

Possui graduação em Pedagogia pelo Instituto de Ensino Superior de Bauru (2008). Concluiu curso de Pós - Graduação - Lato Sensu em Docência no Ensino Médio, Técnico e Superior, pela Associação Educacional do Vale do Itajaí-Mirim (Instituto Passo 1) em 2011. Mestre em Educação para a Ciência - UNESP/Bauru, Doutoranda em Educação para a Ciência - UNESP/Bauru e membro do grupo de pesquisa em Psicologia da Educação Matemática. Possui experiência na área de Educação e atualmente trabalha como docente na Prefeitura Municipal de Bauru, exercendo a função de Coordenadora Pedagógica do Ensino Fundamental I (séries iniciais). Atuou como Orientadora de Estudos do PNAIC (Pacto Nacional pela Alfabetização na Idade Certa), ministrando curso para professores das séries iniciais da Prefeitura de Bauru.

\section{CARLOS ANDRÉ BOGÉA PEREIRA}

Doutor em Educação pela USF-SP (2017), com Doutorado Sanduíche pela Universidade de Lisboa (2015), Mestre em Matemática pela UNICAMP (2011), Especialista em Gestão Escolar pelo IBMECRJ (2014), Especialista em Ensino da Matemática pela UEVA (2004), Pedagogo pela Universidade de Franca-SP (2017). Licenciado em Matemática pela UFMA (2002). Desenvolve trabalhos na área de Formação de Professores, Gestão e Supervisão Escolar, Currículo, Avaliação, Planejamento, Legislação Educacional, Metodologia e Tecnologias no Ensino da Matemática. É formador de professores na SEMED - São Luís. 


\section{CHANG KUO RODRIGUES}

Possui graduação em Licenciatura em Ciências Plenas pelo Centro Universitário de Brasília (1984), mestrado em Educação Matemática pela Universidade Santa Úrsula (1999) e doutorado em Educação Matemática pela Pontifícia Universidade Católica de São Paulo (2009). Atualmente é professora colaboradora do programa de Mestrado Profissional em Educação Matemática da Universidade Federal de Juiz de Fora. Tem experiência na área de Matemática, com ênfase em Educação Matemática, atuando principalmente nos seguintes temas: Educação Financeira, Educação Estatística, Inclusão, Ensino da Matemática na Educação Básica e Superior.

\section{CRISTIANE FERNANDES DE SOUZA}

Professora do Departamento de Ciências Exatas, do Centro de Ciências Aplicadas e Educação, da Universidade Federal da Paraíba (UFPB/campus IV). Licenciada em Matemática pela Universidade Federal de Pernambuco (UFPE), Mestre e Doutora em Educação, na linha de pesquisa Educação Matemática, pela Universidade Federal do Rio Grande do Norte (UFRN). Foi líder do Grupo de Estudos e Pesquisas em Educação Matemática/GEPEM/campus IV no período de maio/2009 a julho/2017. Foi bolsista de produtividade (PQ-2F) do EDITAL MCT/CNPQ 03/2009 (2009-2012). Foi coordenadora das duas turmas do Curso de Especialização em Matemática para o Ensino Fundamental, UFPB/campus IV (2012-2016). Foi coordenadora do subprojeto de Matemática do Programa de Consolidação das Licenciaturas (PRODOCÊNCIA 2008-2010, 2013-2017). Coordenou projetos na área de Ensino de Geometria, com foco na Educação Básica e na Formação Inicial e Continuada de Professores de Matemática, pelo Programa de Licenciatura (PROLICEN/UFPB) (2009, 2013, 2015-2018). Foi Coordenadora de Área de Gestão de Processos Educacionais do PIBID/UFPB (2014-2018). Atou como Assessora de Graduação do CCAE/UFPB/campus IV (2017). Atualmente desenvolve atividades de ensino no curso de Licenciatura em Matemática do campus IV e coordena o subprojeto de Matemática/campus IV da Residência Pedagógica.

\section{DERLI KACZMAREK}

Doutoranda pelo Programa de Pós-Graduação em Educação da Universidade Estadual de Ponta Grossa (PPGE-UEPG) e mestre em Educação pela mesma instituição. Possui graduação em Matemática pela UNICENTRO (1991) e em Ciências-Licenciatura Curta pela Faculdade de Filosofia, Ciências e Letras de Guarapuava (1988); especialização em Metodologia de Ensino em Matemática (1997) e em Educação Especial (2001). É professora de Matemática - anos finais do Ensino Fundamental da Prefeitura Municipal de Araucária. Tem experiência docente na Educação Básica, tendo atuado na Educação Infantil e no Ensino Médio. Atualmente pesquisa sobre Modelagem na Educação Matemática.

\section{DIONÍSIO BURAK}

Possui graduação em Matemática pela Universidade Estadual do Centro-Oeste (1973), mestrado em Ensino de Matemática pela Universidade Estadual Paulista Júlio de Mesquita Filho (1987) e doutorado pela Universidade Estadual de Campinas (1992). Atualmente é rt-20 da Universidade Estadual de Ponta Grossa no Programa de Pós - Graduação em Educação e rt 20 do Programa de Pós-Graduação em Ciências Naturais e Matemática. Professor titular aposentado do Departamento de Matemática da Universidade Estadual do Centro-Oeste em (2013). Tem experiência na área de Matemática, com ênfase em Educação Matemática, atuando principalmente nos seguintes temas: modelagem matemática na educação matemática, ensino e aprendizagem e ensino de matemática. Pós-Doutorado (2010) - Universidade Federal do Pará- orientadora Profa Drâa Rosália Maria Ribeiro de Aragão.Atualmente é Pesquisador Sênior da Fundação Araucária.

\section{EDMUNDO SILVA GUERRA}

Graduado em Matemática pela Universidade Federal Rural de Pernambuco (UFRPE). Especialista em Matemática com Informática pela Faculdade de Igarassu (FACIG). 


\section{ELYS VÂNNY FERNANDA RODRIGUES DE OLIVEIRA}

Pedagoga (UECE), Especialista em Gestão dos Processos Educacionais (FA7), Mestre em Educação Matemática pela Universidade de Anhanguera de São Paulo (UNIAN). Professora de graduação do Curso

Pedagogia (UNI7). Membro do Grupo de Estudos e Pesquisas em Educação e Ludicidade da UFC (GEPEL-CE).

\section{FLÁVIA STREVA NUNES}

Licenciada em Matemática pela Universidade do Estado do Rio de Janeiro (UERJ) com especialização em Neuroeducação. Professora de Matemática da Educação Básica da rede particular.

\section{GABRIELA FÉLIX BRIÃO}

Doutora em Educação Matemática pela UNESP/Rio Claro, com estágio sanduíche de um ano nos Estados Unidos. É professora adjunta da UERJ há mais de dez anos. Na universidade, trabalha com educação básica e também como professora do Programa de pós-graduação em ensino em Educação Básica (PPGEB), além de lecionar em outros programas de pós-graduação. É formadora de professores de matemática.

\section{GEOVANA RAQUEL PEREIRA DA SILVA}

Graduanda do curso de Licenciatura em Matemática pela Universidade Federal da ParaíbaUFPB/Campus IV (2019). Participou do Programa de Licenciatura - PROLICEN/UFPB no ano de 2015, sendo bolsista do projeto, no qual o foco era o Ensino-Aprendizagem da Geometria. 0 desempenho exercido no projeto resultou no Prêmio "Iniciação à Docência" no ano de 2015. Atuou como professora substituta no segundo semestre do ano de 2016 na rede pública de ensino do município de Itapororoca-PB. Em eventos nacionais, regionais e locais publicou artigos na linha de pesquisa Educação Matemática.

\section{GILBERTO FRANCISCO ALVES DE MELO}

Docente do Programa de Pós-Graduação em Ensino de Ciências e Matemática (MPECIM), da UFAC e do Colégio de Aplicação-UFAC. Doutor em Educação Matemática.

\section{JERÔNIMO FREIRE}

Possui graduação em Física (1984) e mestrado em Engenharia Mecânica pela Universidade Federal do Rio Grande do Norte (1994). Tem experiência na área de Ensino de Física, Física e Energia, Educação, com ênfase em Tecnologia Educacional, atuando principalmente nos seguintes temas: educação, tecnologia educacional, simulação, educação - didática e ciências. Atuou como coordenador de Software do Projeto Condigital (MEC/MCT/FNDE) executando o plano geral Física Vivencial: uma aventura do conhecimento, pelo IGGE, cuja conclusão se deu em maio de 2010. Autor do Projeto Laboratório Móvel de Ensino de Ciências (LMEC) / Minha Escola é Sustentável. Professor das disciplinas de Física, cálculos e matemática para as áreas de Engenharias e ciências sociais e aplicadas. Autor de livros com foco no ensino experimental de Ciências, TICs e Sustentabilidade. Consultor do Cidepe - Centro Industrial de Equipamentos de Ensino e Pesquisa.

\section{JOEMILIA MARIA PINHEIRO ALMEIDA}

Mestra em Educação: Gestão de Ensino da Educação Básica pela Universidade Federal do Maranhão - UFMA (2018). Especialização em Docência e Gestão da Educação pela Faculdade Einstein - FACEI (2015). Especialista em Docência do Ensino Superior pelo Instituto de Ensino Superior Franciscano - IESF (2013). Aperfeiçoamento em Matemática- Pró-Ciências promovido pela CAPES/FAPEMA/UFMA/SEEDUC-MA (1997). Licenciada em Matemática pela Universidade Federal 
do Maranhão - UFMA (1997). Atualmente é Professora da Universidade do CEUMA - UNICEUMA. Faz parte do Grupo de Pesquisa, Educação Matemática, Ciências e Produção de Saberes.

\section{JORGE HENRIQUE DUARTE}

Possui graduação em Licenciatura Plena em Ciências com habilitação em Matemática pela Fundação de Ensino Superior de Olinda (FUNESO). Especialista em Ensino de Matemática (UFPE). Mestre em Educação pela Universidade Federal de Pernambuco (UFPE), na linha de Pesquisas em Didática de Conteúdos Específicos. Atualmente é professor titular da Faculdade de Ciências Humanas e Sociais de Igarassu, efetivo da Secretaria de Educação de Recife, efetivo da Secretaria de Educação e Cultura-Pernambuco e Colaborador do IFPE-EAD (Professor Formador do Curso Licenciatura em Matemática). Tem experiência no ensino da Matemática, nos níveis da Educação Básica (Fundamental e Médio) e Superior. Atua como Professor Formador na disciplina Matemática em EAD na FACIG e como formador da Rede Estadual de Ensino de Pernambuco e em Assessorias Pedagógicas. Realiza pesquisas nos seguintes temas: Educação Matemática, Formação de Professores de Matemática, Grandezas Geométricas, Currículo de Matemática e Avaliação em Matemática.

\section{JOSÉ LUIZ MAGALHÃES DE FREITAS}

Possui graduação em Matemática pela Universidade Estadual Paulista Júlio de Mesquita Filho (1976), mestrado em Matemática pela Universidade de São Paulo (1982), doutorado em Didática da Matemática - Université de Montpellier II (USTL) (1993) e pós-doutorado em Educação Matemática pela Universidade Joseph Fourier (2004). Tem experiência na área de Educação Matemática, atuando nos seguintes temas: geometria, aritmética, álgebra, ensino/aprendizagem de matemática na Educação Básica. É professor pesquisador Sênior do INMA-UFMS e atua como professor permanente no programa de pós-graduação em Educação Matemática. A partir de 2018 atua como professor permanente do programa de pós-graduação e Ensino de Ciências e Matemática da Uniderp-Anhanguera, em Campo Grande-MS.

\section{JOSÉ ROBERTO NOGUEIRA}

Possui graduação em Bacharel em Matemática pela Universidade Estadual Paulista Júlio de Mesquita Filho (1985), mestrado em Matemática pelo ICMC/USP, Instituto de Ciências Matemáticas de São Carlos (1990) e doutorado em Matemática Aplicada e Computacional pelo IMECC-UNICAMP , Instituto de Matemática Estatística e Ciência da Computação (1999). Atualmente é Professor Assistente Doutor da FCT-UNESP, Faculdade de Ciências e Tecnologia - Universidade Estadual Paulista Júlio de Mesquita Filho. Tem experiência na área de Matemática, com ênfase em Análise Numérica, atuando principalmente nos seguintes temas: matemática, educação, métodos numéricos, análise e equações diferenciais.

\section{JOSIANE FAXINA}

Mestra do Programa de Pós-graduação em Docência para a Educação Básica pela Unesp/ Bauru. Possui graduação em Pedagogia pela Universidade Estadual Paulista Júlio de Mesquita Filho (2005). Especialista em Psicopedagogia pela Universidade do Sagrado Coração de Bauru - USC (2009). Especialista em Didática do Ensino Superior pela Faculdade Anhanguera de Bauru (2011). Docente por 10 anos no ensino fundamental I, atualmente coordenadora pedagógica - Secretaria Municipal de Educação - Prefeitura de Bauru. Tem experiência na área de Educação, com ênfase em EnsinoAprendizagem. Atuou com formação docente por 3 anos pelo PNAIC - Programa Nacional pela Alfabetização na Idade Certa.

\section{LIANA KRAKECKER}

Possui graduação em Matemática - Licenciatura pelo Instituto Federal Catarinense - Campus Concórdia, especialização em Matemática, Física, Química e Interdisciplinaridade e mestrado em Educação Matemática pelo Programa de Pós Graduação em Educação Matemática (PPGEduMat) da Universidade Federal do Mato Grosso do Sul - UFMS. Possui experiência docente nos níveis 
fundamental - séries finais, médio e superior. Atualmente é doutoranda em Educação Matemática PPGEduMat - UFMS.

\section{LUANA CARDOSO DA SILVA}

Graduanda em Licenciatura em Matemática pela Universidade Federal da Paraíba - UFPB/Campus IV (2019). Foi voluntária (2015) e bolsista (2016-2018) em um projeto de ensino sobre o EnsinoAprendizagem da Geometria, do Programa de Licenciatura - PROLICEN/UFPB, no qual foi agraciada, pelo seu notável desempenho, com o prêmio "Iniciação à Docência" nos anos de 2015 e 2017, concedido pela Pró-Reitoria de Graduação da UFPB, como também recebeu o diploma de "Honra ao Mérito" em 2017, pelo Centro de Ciências Aplicadas e Educação - CCAE/UFPB. Tem formação complementar em "Proposta Curricular e Metodologia na Educação integral - UFPB" (2015). Tem autoria em diversos artigos publicados no âmbito nacional, regional e local, principalmente na área de Ensino de Geometria.

\section{LUCIANA TROCA DANTAS}

Possui graduação em Ciências Contábeis pela Universidade do Estado do Rio de Janeiro (1995) e graduação em Matemática pela Universidade Salgado de Oliveira (2005). Tem experiência na área de Matemática, com ênfase em Matemática. Mestrado Profissional no Ensino das Ciências da Educação Básica pela UNIGRANRIO (2016). Atualmente é Professora da Secretaria municipal de Educação de Duque de Caixas e na Secretaria de educação do Município do Rio de Janeiro. Tem experiência na área de Educação. Atuando principalmente nos seguintes temas: Educação Financeira, EDUCAÇÃO MATEMATICA, , ENSINO FUNDAMENTAL.

\section{MANOEL DOS SANTOS COSTA}

Doutor (2012) e Mestre (2008) em Ensino de Ciências e Matemática pela Universidade Cruzeiro do Sul / São Paulo. Especialista em Matemática pela Universidade Iguaçú (2006) e em Educação Matemática: Metodologia de Ensino e Aprendizagem pela Faculdade de Educação São Luís (2003). Graduado em Ciências (licenciatura) com habilitação em Matemática pela UniFAI (1998) e em Pedagogia (licenciatura) pelo Centro Universitário de Araras (2005). Atualmente é Professor da Secretaria de Estado da Educação do Maranhão e da Universidade Ceuma, em São Luís / MA. Membro do Grupo de Pesquisa em Ensino de Ciências e Ensino de Matemática - GPECEM e do Grupo de Pesquisas e Estudos Avançados em Educação Matemática - GPEAEM. Possui experiência na área de Educação, com ênfase na Educação Matemática, atuando principalmente nas seguintes linhas de pesquisas: Formação (Inicial e Continuada) de professores que ensinam Matemática, Fundamentos e Metodologias do Ensino de Matemática e Resolução de Problemas na Educação Matemática.

\section{MARCELLA CLAUDIA BARBOSA DA SILVA}

Graduada em Licenciatura Plena em Matemática pela Universidade de Pernambuco (UPE). Especialista em Matemática com Informática pela Faculdade de Igarassu (FACIG). Atualmente é professora de Matemática na Rede Privada e na Rede Estadual de Ensino de Pernambuco. Tem experiência na área de ensino da Matemática. Realiza pesquisa nos seguintes temas: Educação de Jovens e Adultos (EJA), Adição e sua Inversa, Educação Matemática, Base conceitual aditiva, Conceito de área em livros didáticos do Ensino Fundamental.

\section{MARCELO RIVELINO RODRIGUES}

Doutor em Educação Matemática pela PUC/SP, Mestre em Educação Matemática pela PUC/SP, Licenciado em Matemática pelas Faculdades Oswaldo Cruz, Bacharel em Matemática pelas Faculdades Oswaldo Cruz, Licenciado em Pedagogia pela Universidade Bandeirantes. Professor titular dos níveis de ensino Fundamental II e Médio a mais de 18 anos das secretarias Estadual de Educação (SEE/SP) e Municipal de Educação (SME/SP). Professor Tutor dos cursos de Engenharia em EAD na Univesp - Universidade Virtual do Estado de São Paulo, nas disciplinas: Cálculo I; Física I; Álgebra Linear. Colaborador do Banco Nacional de Itens (BNI) junto ao Instituto Nacional de Estudos e Pesquisas Educacionais Anísio Teixeira (INEP). Parecerista no Plano Nacional do Livro 
Didático - 2019, junto ao Ministério da Educação (MEC). Assistente Técnico Educacional na Secretaria Municipal de Educação, onde é responsável pelas Avaliações em Larga Escala de Matemática além de atuar como formador em cursos de Elaboração e Revisão de Itens. Foi professor da Rede Salesiana de Escolas ministrando aula para o Ensino Fundamental II. Foi professor de Pós-Graduação na Ethos Consultoria e Assessoria Educacional, onde ministrou cursos de formação continuada para professores da Rede Municipal de Educação de São Paulo.

\section{MARIA DE FÁTIMA CALDAS DE FIGUEIRÊDO}

Mestranda em Ensino de Ciências e Educação Matemática (UEPB). Especialista em Tecnologias Digitais para a Educação Básica (UECE/2018), Especialista em Educação Matemática (ISEC/2015) e Graduada em Licenciatura em Ciências com Habilitação em Matemática (UFCG/2014).

\section{MARIA INMACULADA CHAO CABANAS}

Doutora em Educação pela Universidade Estácio de Sá (2017) na Linha de Pesquisa das Representações Sociais. Mestre em Educação (2007) na linha de pesquisa das Tecnologias da Informação e Comunicação. Graduada e especialista em Matemática pela Universidade Federal do Rio de Janeiro (1997). Professora Substituta da Faculdade de Educação da Universidade Federal do Rio de Janeiro até 2008 (UFRJ) nas disciplinas de Didática da Matemática e Prática de Ensino (2008). Atuando desde 2003, como docente na Universidade Estácio de Sá nas licenciaturas de Matemática e Pedagogia e, atualmente, como gestora Nacional de Curso - Matemática e Pedagogia (Diretoria de Ensino-Graduação). Participa de políticas públicas de formação de professores (Proletramento e Pnaic), no Programa de Avaliação do Livro Didático? PNLD, Avaliações em Larga Escala (Prova Brasil, ANA e ENADE. Professora de matemática aposentada da educação básica das redes de educação municipal e estadual do Rio de Janeiro. É avaliadora do sistema SINAIS - BASis. A sua experiência está voltada para a área de Educação (Matemática) e Educação a Distância (formação de tutores), com ênfase no Ensino e Aprendizagem de Matemática e Formação Docente nos diferentes níveis de ensino. Com produção científica apresentada no Brasil e no exterior na linha das Representações Sociais e Retórica no contexto da Ciência Matemática, Escolarização em Matemática, Exames Nacionais e Formação de Professores. Participa do grupo de Pesquisa: Retórica e Argumentação em Pedagogia (https://www.rho-alfa-pi.org/retorica-e-argumentacao-napedagogi).Orcid: https://orcid.org/0000-0002-0368-8416)=

\section{MICHELE DE SOUZA MORAES}

Mestra do Programa de Pós-graduação em Docência para a Educação Básica pela Unesp/ Bauru. Possui graduação em Licenciatura em Matemática pela Universidade Estadual Paulista; Júlio de Mesquita Filho (2011), especialização em Ética, Valores e Cidadania na Escola pela Universidade de São Paulo (2013), especialização em Matemática pela Universidade Federal de São João Del-Rei (2014). Pertence ao grupo de pesquisa HEEMa (História e Epistemologia na Educação Matemática). Docente há 8 anos no ensino fundamental II e ensino médio. Atualmente é professora efetiva de matemática da Secretária Estadual de Educação do Estado de São Paulo e da Secretaria Municipal de Educação - Prefeitura de Bauru.

\section{RUTH BRITO DE FIGUEIREDO MELO}

Doutoranda em Engenharia de Processos pela UFCG (2015), Mestre em Ensino de Ciências e Matemática (2011) e Licenciada em Física (2003) pela (UEPB). Possui curso de aperfeiçoamento em TIC (Tecnologias da Informação e comunicação) e em Elaboração de Projetos, ambos pelo MEC/PROINFO e NTE (Núcleo de Tecnologia Educacional) da Paraíba (2011), e de Atualização em EaD pela UEPB (2016). Professora Efetiva do Centro de Ciências Exatas e Tecnológicas da (UEPB/CAMPUS I) 


\section{VALQUIRIO FIRMINO DA SILVA}

Mestre em Ensino de Ciências e Matemática (MPECIM), da Universidade Federal do Acre - UFAC. Especialista em Educação Matemática e Graduado em Licenciatura em Matemática, pela UFAC. Docente/Diretor da Escola Municipal Sheyla Nasserala, em Rio Branco - Acre.

\section{WALÉRIA DE JESUS BARBOSA SOARES}

Doutora em Ensino de Ciências e Matemática pela Unicamp (2017), Doutorado Sanduíche pela Universidade do Porto-Portugal (2015), Mestre em Matemática pela Unicamp (2009), Especialista em Gestão Escolar pelo IBMEC-RJ (2014), Especialista em Cinema e Linguagem Audiovisual pela UGF (2014), Especialista em Ensino da Matemática pela UEVA (2004), Pedagoga pela Universidade de Franca-SP (2017), Graduada em Matemática e Artes Visuais, ambas pela UFMA. Atualmente integra o GHEMAT - Grupo de Pesquisa de História da Educação Matemática no Brasil. Desenvolve pesquisas sobre História da Educação e do Ensino da Matemática, Currículo e Formação de Professores e Avaliação de Aprendizagem. É formadora de professores na SEMED - São Luís. 
Agência Brasileira do ISBN

ISBN 978-85-7042-087-9

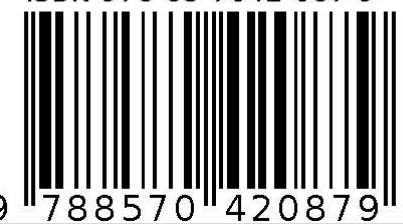

